\title{
Anatomical Patterns of Some Aquatic Vascular Plants of New York
}

\author{
Eugene C. Ogden \\ State Botanist
}

BULLETIN 424

New York State Museum and Science Service

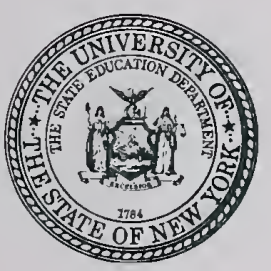





\title{
Anatomical Patterns of Some Aquatic Vascular Plants of New York
}

\author{
Eugene C. Ogden \\ State Botanist
}

BULLETIN 424

New York State Museum and Science Service

The University of the State of New York

THE STATE EDUCATION DEPARTMENT

Albany, New York 1974 


\section{THE UNIVERSITY OF THE STATE OF NEW YORK}

Regents of The University (with years when terms expire)

1984 Joseph W. McGovern, A.B., J.D., L.H.D., LL.D., D.C.L.,

Litt.D., Chancellor - - - - - - - - - - - New York

1981 Theodore M. Black, A.B., Litt.D., LL.D., Pd.D., - - - -

Vice Chancellor . . . . . . . . . . . Sands Point

1978 Alexander J. Allan, Jr., Ll.D., Litt.D. - - - - • - Troy

1987 Carl H. Pforzheimer, JR., A.B., M.B.A., D.C.S., H.H.D. - Purchase

1975 Edward M. M. Warburg, B.S., L.H.D. - - . - . - . New York

1980 JoSEPH T. KING, LL.B. - . . . - . - . - . Shelter Island

1981 Joseph C. IndeliCato, M.D. - - - . - . - . - Brooklyn

1976 Helen B. Power, A.B., Litt.D., L.H.D., LL.D. - - - - - Rochester

1979 Francis W. McGinley, B.S., J.D., LL.D. - - - - • Glens Falls

1986 Kenneth B. Clark, A.B., M.S., Ph.D., LL.D., L.H.D., D.Sc. Hastings

on Hudson

1983 HaRold E. Newcomb, B.A. - . . . . . . . Owego

1988 Willakd A. GenRich, LL.B., L.H.D. • - . . . . Buffalo

1982 Emlyn I. Griffith, A.B., J.D. - - - - - - - Rome

1977 Genevieve S. Klein, B.S., M.A. - - - - - - - - Bayside

1981 William Jovanovich, A.B., LL.D., Litt.D., L.H.D. - - - B Briarcliff

Manor

President of The University and Commissioner of Education

Ewald B. Nyquist

Executive Deputy Commissioner of Education

Gordon M. Ambach

Associate Commissioner for Cultural Education

JohN G. BROUGHTON

Assistant Commissioner for State Museum and Science Service

Noel C. Fritzinger

Director, Science Service

Hugo JAMNBACK

Chief, Biological Survey

SA YeEd QuRaishi

State Botanist

Eugene C. Ogden 


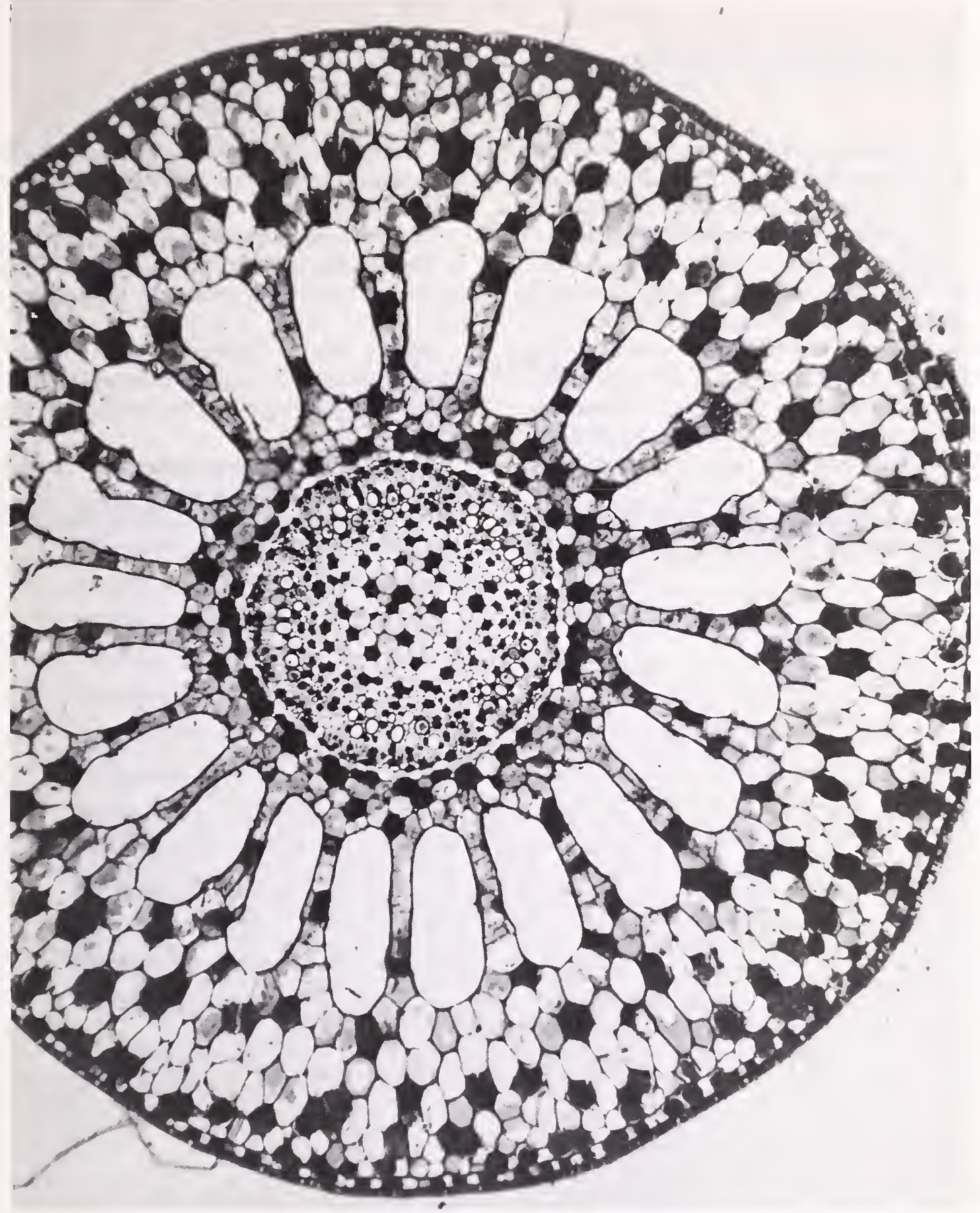

Myriophyllum brasiliense stem $\times 65$

See Plate 54 for comparison of photomicrograph and drawing. 


\section{Acknowledgments}

Special credit and thanks go to Stanley J. Smith for collections of histological material, for advice regarding classification and nomenclature, and for locations of uncommon species. The maps were prepared from the range maps in his charge and kept current by him.

J. Kenneth Dean prepared many of the permanent microscope slides and the freehand sections for comparisons. His help with the anatomical descriptions is much appreciated. He prepared all of the 208 maps.

Dr. Fay Hyland, University of Maine, reviewed the final manuscript and suggested several improvements. He prepared the slides that were used to illustrate Najas and Sagittaria.

Richard W. Snook prepared most of the illustrations (62 plates). His training in both botany and art was especially helpful.
Donald J. Moore processed much of the histological collections to microscope slides and prepared four of the plates of illustrations.

Dr. James R. Nolan, State University of New York at Plattsburgh, supplied the microscope slides with interpretive notes from which the illustrations of Isoetes were made.

Slocum Water Gardens, Winter Haven, Florida, kindly supplied histological material of Nelumbo.

Eileen T. Coulston handled most of the bibliographic work.

Nancy M. Farr saw the manuscript through all of its typing and proofreading stages.

The frontispiece was prepared by John H. Haines. 


\section{Contents}

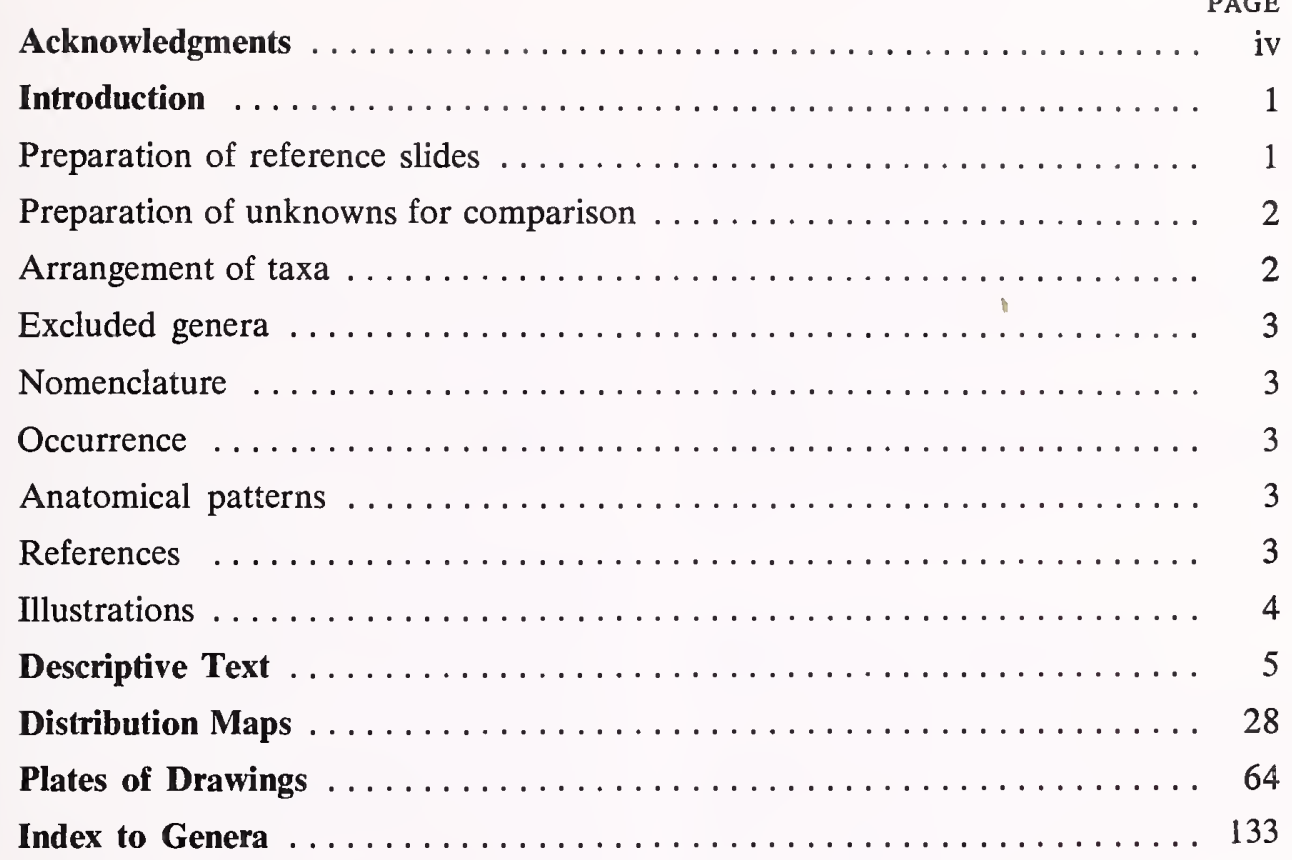


Digitized by the Internet Archive in 2017 with funding from IMLS LG-70-15-0138-15 


\title{
Anatomical Patterns of Some
}

\section{Aquatic Vascular Plants of New York $^{1}$}

\author{
Eugene C. Ogden, State Botanist \\ New York State Museum and Science Service
}

\section{INTRODUCTION}

In several types of research, it is desirable to determine the identity of aquatic vascular plants that are sterile and fragmentary. Available floristic manuals frequently are not adequate for this. It is often necessary to seek characters not available from external morphology. Internal anatomical patterns of stem internodes offer additional characters. Published information on this is widely scattered or nonexistent. The purpose of this Bulletin is to bring together in convenient form useful anatomical patterns of the frequently encountered vascular plants that grow in water.

The usual definition of aquatic plant (i.e., growing in water) may not be most desirable here. Fragments from the stomachs of wild waterfowl and aquatic mammals may include material that did not grow in water. As most truly aquatic vascular plants are characterized by having much aerenchyma tissue, this character, which is readily seen in cross section, may be chosen for determining if the plant is likely aquatic. Thus, the definition of an aquatic plant, for purposes of this treatment, is one having a stem or stemlike parts in which the cross section area (excluding the pith, if it is hollow) is at least 50 percent lacunate, i.e., noncellular portions cover at least half of the area. Exclusion of the hollow pith is necessary to eliminate large groups of dry area plants as in the Gramineae and Umbelliferae. With this circumscription of "aquatic plants," dry habitat species of Equisetum are still included.

Stemlike parts include root, rhizome, stem (used here to exclude rhizome for convenience, brevity, and usefulness), leaf (usually the petiole) and peduncle (including pedicel). In a few cases a young fruit might be stemlike, such as Vallisneria. Genera are excluded if only the roots are lacunate. Roots of the aquatic genera are similar and offer little help in identification.

${ }^{1}$ Manuscript submitted for publication April 25, 1974.
Stemlike shapes in cross section may be circular to triangular or flattened, but with the longest diameter no more than five times the shortest diameter. As extremely slender fragments generally do not have useful discernible anatomical patterns, those less than 1 millimeter in longest diameter are mostly not included. Those greater than $10 \mathrm{~mm}$ in shortest diameter are also excluded.

This is a book on anatomical patterns rather than on anatomy. Its slant is taxonomic rather than anatomic.

\section{Preparation of reference slides}

Histological material of submersed and emersed stemlike organs was collected from various parts of vascular plants and stored in FAA killing and preserving solution. Standard herbarium collections for vouchers were taken for filing in the herbarium of the New York State Museum and Science Service, unless the species identity was not in question and the species had been sampled previously for anatomical studies and vouchered at least once. Usually an additional collection was taken for making comparative anatomical studies from dried pressed material as found in the usual herbarium. Details of the process of preparation of the microscope slides are unnecessary here. The paraffin method was used. The sections were cut with a rotary microtome at a thickness from 10 to 30 microns. Staining was with safranin and fast green. The tissues were sealed in Canada balsam. For some rare species, which would require an unwarranted amount of effort to obtain as fresh material and in a genus having one or more species in the fresh specimen collections, dried herbarium material was obtained, boiled in water to soften and expand, and then processed by the paraffin method. Because of 
the large number of collections to be processed and because fine detail (such as structure of the cell wall and nature of the cell contents) was not needed, rapid methods of slide preparation were employed. Occasionally, when requested, the technicians processed material from vacuumed preserving solution to the stained and mounted slides in 7 or 8 hours.

\section{Preparation of unknowns for comparison}

Material for identification may be from sterile specimens, fragments at the shore or on feeding platforms, from animal stomachs, etc. It may be preserved in some fluid or as dried material. It is seldom feasible or necessary to process this material as for research-quality microscope slides. Simpler and quicker methods usually will provide adequate mounts for determining the anatomical patterns. Although any of several methods may be employed, the following is what I use at the present time and have found to be satisfactory during the past 35 years.

Dried material, a few millimeters long, is boiled in water or emersed in a detergent to soften and expand the tissues, then dropped into cold water to reduce flabbiness. Fresh or otherwise soft material need not be boiled. Place the following items near a dissecting microscope: flat paper towel, $3 \times 5$ index card, sharp safety razor blade, open vial of fountain pen ink (washable blue Skrip), tweezers, two dissecting needles with very slender tips, glass microscope slide (preferable the concavity or depression type), and small container (finger bowl) of cold water. Place a drop of water on the slide. Move the material, without undue crushing, to the towel to remove excess water. Move the material from the towel to the card. Place under the scope. Make a clean transverse cut near one end. Grip the other end with tweezers and dip the cut end into the ink for a few seconds. Rinse briefly in cold water and place on the towel again. It may be rolled a bit or squeezed slightly to remove excess water. It is now moved to the card again and oriented as when the first cut was made. Cut a thin freehand section from the stained end. This should remain attached to the razor blade. Place the microscope slide under the scope and with a needile push the tissue into the drop of water, stained end up. Usually one such section is enough but several of different thicknesses may be helpful, some being stained, some unstained. Under the dissecting scope, at a magnification of 5 to 10 , use the two needles to pull the tissue into expanded form. This is done by hooking the needle push the tissue into the drop of water, stained end outward. A small amount of tearing is not objectionable. The gross anatomical pattern can be seen at low magnification. For greater detail, move the slide to a microscope at 100 diameters. The lacunae allow enough light to come through to illuminate most of the cells.

Color differentiation in these mounts varies greatly among the different genera and even with preparations from the same bit of tissue. Ideally the cellulose walls retain the blue stain and those with suberin or lignin appear yellowish.

If these mounts are needed for later observation or for permanent storage, a water-missible mounting fluid (such as glycerin jelly) is placed on the slide instead of water. A freehand, inkstained section of a Potamogeton stem sealed on a depression slide with Karo syrup is well preserved 30 years later.

Glycerin jelly mounts are easily made. Commercial glycerin jelly may be used. A formula which we like is: 2 parts gelatin, 12 water, 11 glycerin, $2 \%$ phenol (1 part to each 50 parts of the glycerin jelly). Mix the gelatin and water. The mixture may be warmed slightly to dissolve the gelatin faster. When dissolved, add the glycerin and phenol. Let stand overnight. Strain through cheesecloth. Prestained glycerin jelly eliminates the need to stain before mounting. We add a drop of saturated aqueous basic fuchsin to each $15-20 \mathrm{ml}$ of the glycerin jelly. This jelly is stored as a solid and warmed to a liquid (in a water bath) for use. On standard flat microscope slides, as the jelly dries and the cover glass settles, the thick-cut sections may be distorted unless some rim-sealing material (such as epoxy, nail polish, or paraffin) is used. More satisfactory, except for cost, is the commercial depression (concavity) slide.

\section{Arrangement of taxa}

The genera are listed in the general sequence in which they appear in currently used floristic manuals: horsetails, quillworts, ferns, monocots, and dicots. The species of each genus are listed in alphabetical order. Each species name encompasses all subspecific taxa in the State. It is expected that users of this Bulletin will have access to one or more of the following five books which include the aquatic vascular plants of New York State.

Fassett, N.C. 1957. A manual of aquatic plants. Revised ed. University of Wisconsin Press, Madison.

Fernald, M.L. 1950. Gray's manual of botany. 8th ed. American Book. 
Gleason, H.A. 1952. The new Britton and Brown illustrated flora of the northeastern United States and adjacent Canada. New York Botanical Garden.

House, H.D. 1924. Annotated list of the ferns and flowering plants of New York State. New York State Museum Bulletin No. 254. 759 p.

Muenscher, W.C. 1944. Aquatic plants of the United States. Comstock.

\section{Excluded genera}

Genera with herbaceous species found growing in water but with parts (except roots) not sufficiently lacunate to be included here. Some are listed in the text but not illustrated:

$\begin{array}{ll}\text { Cicuta } & \text { Rorippa } \\ \text { Cyperus } & \text { Samolus } \\ \text { Impatiens } & \text { Sium } \\ \text { Podostemum } & \text { Typha } \\ \text { Polygonum } & \text { Veronica } \\ \text { Ranunculus } & \text { Zostera }\end{array}$

With stemlike parts lacunate but too small. Some of these are listed in the text but are not illustrated:

$\begin{array}{ll}\text { Callitriche } & \text { Limosella } \\ \text { Echinodorus } & \text { Littorella } \\ \text { Elatine } & \text { Subularia }\end{array}$

Plants that generally are not lacunate but may produce some aerenchyma in the cortex of submersed parts when growing in water:

$\begin{array}{ll}\text { Cardamine } & \text { Lythrum } \\ \text { Decodon } & \text { Mentha } \\ \text { Distichlis } & \text { Peplis } \\ \text { Epilobium } & \text { Phragmites } \\ \text { Lycopus } & \text { Scutellaria }\end{array}$

Plants that are lacunate but rare, and suitable material not available for study:
Hottonia
Limnobium

\section{Nomenclature}

The scientific names are chosen according to the most recent and authoritative taxonomic opinions. If the name used in one or more of the above five reference books differs from the one chosen here, that name appears as a synonym. Such names are in parentheses. Some obvious synonyms, as for subspecific taxa, are not included.

\section{Occurrence}

Statements about relative abundance refer only to New York and only to those areas in the State where it is found. This varies for different localities and the remarks are, of necessity, generalized.

The maps indicate the areas of occurrence. They were prepared from the range map file in the New York State Herbarium, which is kept current by Stanley J. Smith, Senior Scientist and Curator.

Habitat data refer to the usual situations but are meant to be inclusive for all types of habitat where the species may be found adjusted to its environment.

\section{Anatomical patterns}

Generalized descriptions of the patterns are given for each genus, calling attention to characters useful in comparing tissue preparations with the illustrations. For genera with more than one species, the description is under the genus heading with additional remarks under those species that vary sufficiently to warrant them. For genera with but one species, this description appears under the species heading, refers only to this species, and may or may not include patterns of species not found in the State. In general, characters that are obvious from the illustrations and those that are of doubtful value are not described.

Diameter measurements represent what are usually encountered and not the uncommon extremes. All measurements refer to diameters in cross section unless otherwise stated.

\section{References}

The references are those that have illustrations of the cross sections of lacunate stemlike parts. They are chosen to indicate availability of illustrations that are useful to supplement those in this Bulletin. Such references under the genus are included even though the species illustrated may not be found in New York. Although they are chosen primarily for their useful illustrations, a few are included because of important descriptive material. Importance, here, refers to their value for making comparisons and as aids in identification of unknowns, rather than learned discussions of anatomical features. Only in rare cases are references included that have no pertinent illustration. References are favored if readily available and in the English language.

Decisions about whether to include certain published illustrations were frequently difficult to make. Many diagrams showing tissue regions and many drawings or photographs of small portions of the plant organ (such as details of a vascular bundle) might be useful, if readily at hand. However, many of these were judged not sufficiently useful to warrant encouraging the user of 
this Bulletin to take the estimated amount of time necessary to locate them.

If the illustration is of a species found in New York, the plate or figure number is cited under the species entry; if of a species not in the State, it is cited under the genus entry.

\section{Illustrations}

The line drawings were made directly with ink on translucent drafting film from projected images of the tissues mounted on microscope slides. A microscope with lenses for a wide range of magnifications, zoom control, and a high intensity light with rheostat, was perched on an adjustable jack in a specially constructed box with a plate glass top. The desired image was focused on the drafting film which allowed each cell wall to be traced with great accuracy. The original plates are $12.5 \times 21$ inches. All drawings are of transverse (cross section) views. They are drawn from thin sections (mostly 20 microns) even though designed for comparison with thicker freehand sections. The magnification of each drawing is indicated by the length in millimeters of a line, sometimes to be multiplied by the circled factor. The labels are simple and self-explanatory. 


\section{Descriptive Text}

This, the main portion of the book, will be used in different ways for different requirements. The plates of drawings are purposely placed together to facilitate rapid matching of illustrations with the anatomical preparation of the plant to be identified. After illustrations are chosen which are similar to the unknown, one may locate those genera in the text (by referring to the index) where the characters to observe are given and where the names of other genera that might be possibilities are suggested.

\section{EQUISETUM}

Nine species in New York.

Maps 1-8, Plates 1-3

Anatomical patterns somewhat variable in the genus but mostly uniform for each species. Stems terete but often with prominent ridges, from less than 1 to $20 \mathrm{~mm}$; usually with one or several large lacunae and many smaller lacunae; outer circle of lacunae (vallecular cavities) alternate with the ridges.

Agashe, S.N. 1968. Phloem studies in the pteridophytes, Part I. Equisetum. Am. Fern J. 58:74-77. Pl. 9, fig. 1: stem.

Bierhorst, D.W. 1971. Morphology of vascular plants. Macmillan.

Bold, H.C. 1967. Morphology of plants. 2d ed. Harper \& Row.

Eames, A.J., 1936. Morphology of vascular plants: lower groups. McGraw-Hill. Fig. 69: stem.

Fernald, M.L. 1950. Gray's manual of botany. 8th ed. American Book.

Foster, A.S., and E.M. Gifford, Jr. 1959. Comparative morphology of vascular plants. W.H. Freeman, San Francisco, Calif.

Gleason, H.A. 1952. The new Britton and Brown illustrated flora of the northeastern United States and adjacent Canada. Vol. 1. New York Botanical Garden.

Hauke, R. 1963. A taxonomic monograph of the genus Equisetum subgenus Hippochaete. Beihefte zur Nova Hedwigia, Heft 8:1-123.

Haupt, A.W. 1953. Plant morphology. McGraw-Hill.

Holden, R. 1915. The anatomy of a hybrid Equisetum. Am. J. Bot. 2(5):225--237.

Jeffrey, E.C. 1899. The development, structure, and affinities of the genus Equisetum. Boston Soc. Nat. Hist. Memoir 5:155-190.

Johnson, M.A. 1933. Origin and development of tissues in Equisetum scirpoides. Bot. Gaz. 94:469-494.

Korsmo, E. 1954. Anatomy of weeds. Grondahl \& Sons, Oslo, Norway.

Milde, J. 1865. Monographia equisetorum. Verhandl. der Kaiserlichen Leopoldino-Carolinischen deutschen Akad. der Naturforscher 32(2):1-605.
Scagel, R.F., R.J. Bandoni, G.E. Rouse, W.B. Schofield, J.R. Stein, and T.M.C. Taylor. 1965. An evolutionary survey of the plant kingdom. Wadsworth, Belmont, Calif. Fig. 20-13: stem.

\section{E. arvense}

Common and often abundant. In dry or damp soil.

Main stem 1.5-5 mm, with 8-14 ridges; branch stems with as few as 3 ridges; central cavity small, $\pm 1 / 4$ diam of stem; vallecular cavities large.

References: Bold, fig. 20-5: stem. Fernald, fig. 1: stem. Gleason, p. 15: stem. Jeffrey, pl. 28, fig. 6: node. MILDE, pls. 1--3: stem.

\section{E. fluviatile}

This is our commonest species in lakes, being found in open quiet water to several feet in depth; also on the shores and in swamps.

Main stem 2-8 mm, shallowly 10--30-ridged; central cavity $4 / 5$ (or more) diam of stem; vallecular cavities absent, except sometimes near base of stem.

References: Fernald, figs. 10, 11: stem. Gleason, p. 17: stem.

\section{E. hyemale (E. laevigatum, E. praealtum)}

Common on dry or wet banks and along shores of ponds and streams.

Main stem 2-20 mm, mostly with $14-40$ ridges; ridges broad and rounded; central cavity $3 / 4$ (or more) diam of stem; vallecular cavities small. Superficially similar to the stem or the connate sheath of some sedges, such as Dulichium and Cladium.

References: EAmEs, fig. 69: stem. Fernald, figs. 13, 15: stem. Foster and GifFord, fig. 9-3: stem. GleASON, p. 17: stem. Haupt, fig. 210: stem. Holden, figs. 11, 12, 17: rhizome and stem. JefFrey, pl. 28, fig. 3: node. Milde, pls. 29, 30: stem.

\section{E. palustre}

Local. Marshes and wet shores.

Main stem 1-4 mm, deeply 5-10-ridged; ridges smooth or rough but not spinulose; central cavity small, mostly $\pm 1 / 6$ diam of stem; vallecular cavities very large.

References: Fernald, fig. 6: stem. Gleason, p. 15: stem. Korsmo, pls. 3, 4: root, rhizome, and stem. Milde, pls. 13, 14: rhizome and stem. 


\section{E. pratense}

Rare. Moist soil of stream banks and alluvial woods.

Main stem 1-3 mm, with 10-20 ridges; ridges broader than the furrows, slightly roughened; central cavity $\pm 1 / 3$ diam of stem. Branch stems mostly 3-angled.

References: Fernald, fig. 2: stem. Gleason, p. 15: stem. Korsmo, fig. 8: stem. Milde, pls. 7, 8: stem.

\section{E. scirpoides}

Frequent. Moist shady banks.

Stem $0.7-1 \mathrm{~mm}, 6$ (rarely 8 )-ridged; central cavity absent; vallecular cavities 3 or 4 , large.

References: Bierhorst, fig. 7-3: stem. Fernald, fig. 16: stem. Gleason, p. 17: stem. Johnson, pl. 8, figs. 31--35: root, rhizome, and stem. Milde, pl. 35: stem.

\section{E. sylvaticum}

Common. Moist sandy woods.

Main stem 1-4 mm, with 10-18 ridges with vallecular cavities between; central cavity more than $1 / 2$ diam of stem.

References: Fernald, fig. 5: stem. Gleason, p. 15: stem. Jeffrey, pl. 28, fig. 5: node. Korsmo, pls. 5, 6: root and stem. MiLdE, pls. 9, 10: stem.

\section{E. variegatum}

Local. Moist banks and low woods.

Main stem 1-2 mm, 5-10-ridged, the ridges furrowed, with 2 rows of silicious tubercles; central cavity $1 / 4$ to $1 / 3$ diam of stem; vallecular cavities large.

References: BIERHORST, fig. 7-3: stem. GleASON, p. 17: stem. Holden, figs. 7-10, 13-16: rhizome and stem. Milde, pl. 34: stem.

\section{ISOETES}

Maps 9-14, Plate 4

Six species in New York, I. echinospora being the most common and the only species examined.

Bold, H.C. 1967. Morphology of plants. 2d ed. Harper \& Row. Fig. 19-35: root.

Sculthorpe, C.D. 1967. The biology of aquatic vascular plants. St. Martin. Fig. 5.15: diagram of leaf.

Smith, G.M. 1955. Cryptogamic botany, 2d ed. Vol. 2. Bryophytes and pteridophytes. McGraw-Hill. Fig. 138: root.

Stokey, A.G. 1909. The anatomy of Isoetes. Bot. Gaz. 47:311335 , pl. 20.

\section{I. eatonii}

Rare. Shallow water and wet shores.

\section{I. echinospora (I. braunii, I. muricata)}

Frequent. Shallow water of lakes and streams.

Stem (rootstock) not lacunate. Roots less than $1 \mathrm{~mm}$, with a small vascular bundle surrounded by a thin-walled endodermis; cortex of large thin-walled cells and with a single large lacuna. Leaves, above the base, terete; from less than 1 to $3 \mathrm{~mm}$, usually $1-2 \mathrm{~mm}$ at the middle; in the center is a single small vascular bundle; the cortex may have none or 4 small bundles alternating with the 4 large lacunae; epidermis of emersed portion of leaf with stomata. These leaves might be confused with the tiny leaves (less than $1 \mathrm{~mm}$ ) of Littorella and Limosella, which have only 2 lacunae.

Reference: STOKEY, pl. 20, fig. 9: leaf.

\section{I. engelmannii}

Uncommon. Shallow water and mud of lakes and ditches.

\section{I. macrospora}

Rare or overlooked. Shallow to deep water of lakes and strearns.

\section{I. riparia}

Rare. On muddy soil or in shallow water of river and lake shores.

\section{I. tuckermanii}

Occasional. Sandy lake shores.

\section{MARSILEA}

Map 15, Plate 5

One species in New York.

Allsopp, A. 1954. Experimental and analytical studies of pteridophytes. XXIV. Investigations on Marsilea. 4. Anatomical effects of changes in sugar concentration. Ann. Bot., N.S. 18:449-461. Pls. 23, 24: root, rhizome, and leaf.

Bierhorst, D.W. 1971. Morphology of vascular plants. Macmillan.

Bold, H.C. 1967. Morphology of plants. 2d ed. Harper \& Row. Figs. 23-4, 23-5: root, rhizome, and leaf.

Gaudet, J.J. 1964. Morphology of Marsilea vestita. II. Morphology of the adult land and submerged leaves. Am. J. Bot. 51:591-597. Figs. 14 to 21: leaf.

Haupt, A.W. 1953. Plant morphology. McGraw-Hill.

Scagel, R.F., R.J. Bandoni, G.E. Rouse, W.B. Schofield, J.R. Stein, and T.M.C. Taylor. 1965. An evolutionary survey of the plant kingdom. Wadsworth, Belmont, Calif. Fig. 21-58: rhizome. (This illustration redrawn from Smith 1955.)

Sculthorpe, C.D. 1967. The biology of aquatic vascular plants. St. Martin. Fig. 6.8: rhizome.

Smith, G.M. 1955. Cryptogamic botany. 2d ed. Vol. 2. Bryophytes and pteridophytes. McGraw-Hill. Fig. 239: rhizome. (This illustration repeated in Scagel et al. 1965.) 


\section{M. quadrifolia}

Not native, but now found in a few localities where it may be an abundant weed. Lake shores, small pools, and siow streams.

Rhizome terete, 1-2 $\mathrm{mm}$, with a large nonlacunate central area having 2 circles of endodermis; the inner circle may be indistinct in young tissues; cortex with a single circle of lacunae separated by 1 -cell-wide chains of cells. The pattern is similar to that of the stems of Myriophyllum and Gratiola, and sometimes also Najas, Zannichellia, and Ceratophyllum, but from all these the mature rhizome is distinguished by the 2 circles of endodermis. Petiole mostly less than $1 \mathrm{~mm}$, with a small nonlacunate central portion and a single circle of large lacunae in the cortex.

References: BIERHORST, fig. 17-2: stem. HAUPT, fig. 249: rhizome.

\section{SPARGANIUM}

Maps 16-22, Plates 6-7

Seven species in New York.

Roots similar in all species; cortex becoming lacunate with large radially arranged lacunae; central area (stele) often with large circular lacunae. Rhizomes, stems, and peduncles similar. Rhizome 2-6 mm; stem $1-10+$ mm; peduncle $1-6 \mathrm{~mm}$. Central area of each with numerous bundles, scattered toward the center but forming a ring near the outer portion; ground parenchyma among the bundles not lacunate but becoming lacunate outside the bundle ring (cortex). Submersed stems more lacunate than emersed stems. Somewhat similar to a teretestemmed Scirpus. Peduncles often lacking lacunae. Leaves in cross section triangular to plano-convex to thin, with prominent midrib; lacunae large, separated by 1-cell-wide chains of cells; with bundles at most of the junctures.

Kaul, R.B. 1972. Adaptive leaf architecture in emergent and floating Sparganium. Am. J. Bot. 59:270-278.

\section{S. americanum}

Frequent. Marshes and margins of lakes. Mostly emersed. Stem 1-3 mm.

Reference: KaUL, fig. 10: leaf.

\section{S. androcladum}

Frequent. Shallow water of marshes and bogs. Mostly emersed. Stem 1-3 mm.

\section{S. angustifolium}

Common in the Adirondacks, occasional elsewhere. Cold lakes and slow streams. Mostly submersed. Stem 1-2 mm.

\section{S. chlorocarpum}

Occasional to frequent. Boggy ponds, marshes, and slow streams. Mostly emersed. Stem 1-3 mm.

\section{S. eurycarpum}

Common over most of its range in the State, but infrequent on Long Island. Shallow water of marshes, streams, and lakes. Mostly emersed. Stem $2-10+$ mm. Our largest species, but parts vary greatly in size.

Reference: KaUL, fig. 11: leaf.

\section{S. fluctuans}

Common in the Adirondacks, occasional elsewhere. Cold lakes. Mostly submersed. Stem 1-2 mm.

Reference: KaUL, fig. 12: leaf.

\section{S. minimum}

Frequent in the Adirondacks, rare elsewhere. Ponds and slow streams, usually on a soft bottom. Stem 1-2 $\mathrm{mm}$. Our smallest species.

Reference: KaUL, fig. 13: leaf.

\section{POTAMOGETON Maps 23-50, Plates 8-14}

Twenty-eight or 29 species in New York.

Anatomical patterns variable in the genus but mostly uniform for each species.

Stems terete to flattened, from less than 1 to $4 \mathrm{~mm}$ in longest diam, with a central stele enclosed by an endodermis and a broad lacunate cortex. Stele composed of fibrovascular bundles, mechanical tissue, and parenchyma cells; xylem of each bundle usually merely a single unwalled opening, often appearing like a lacuna, sometimes remnants of the tracheid wall persist; phloem area of each bundle may or may not be distinct. Arrangement of bundles in the stele varies with different species. Four patterns may be recognized: (1) Proto type. Bundles all free, each having 1 patch of phloem, 4 of them median and with a few smaller bundles on each side (pl. 13). (2) Trio type. Three of the median bundies fused to form a single xylem canal, with 1 patch of phloem on the outer face and 1 or 2 on the inner face of the xylem canal (pls. 10, 12). (3) Oblong type. Median bundles 1 or 2 , with no phloem on the inner faces; lateral bundles 1 (or 2) on each side; shape of the stele oblong or elliptical (pls. 9, 14). (4) One-bundled type. Only 1 bundle, with 4 patches of phloem which often are not evident (pl. 8B).

Endodermis usually evident. The cells may have thin walls and appear similar to the cells of the cortex or they may have thick walls and are more clearly evident. Two cell types are recognized: O-cells, having the wall thin or evenly thickened (pls. 12, 13); U-cells, having the 
wall thickened on the inner and lateral faces but thin on the outer face next to the cortex (pls. 9, 10, 11).

Cortex highly lacunate. This area may be without bundles (pls. 12,13) or bundles of vascular tissue and fibers or of fibers alone at some of the junctures of the chains of cells separating the lacunae (pls. 9, 10, 11, 14). These are called interlacunar bundles. Cortical bundles adjacent to the epidermis are called subepidermal bundles. They may be present (pls. 10, 14) or absent (pls. 11,12,13). In some species, the outermost lacunae are adjacent to the single-layered epidermis ( $\mathrm{pl}$. 14 ); in others, 1 or more layers of cortical cells are between the lacunae and the epidermis (pls. 10, 12, 13). These cells are not thickened but do add support to a highly lacunate stem. This area is the pseudohypodermis.

Rhizome anatomy similar to that of the other stems. Any differences are mentioned under the species descriptions. Rhizomes are absent in many species. Roots less than $1 \mathrm{~mm}$, lacunate or not. Petioles of floating and submersed leaves are described and illustrated where pertinent.

Peduncles lacunate, usually with 2 to 4 large central bundles; other bundles may or may not be present; endodermis mostly absent (pls. 10, 12, 14) but present (pl. 11 ) in $P$. filiformis, $P$. pectinatus, and $P$. vaginatus.

The stem of Hydrocotyle is similar to some species of Potamogeton.

Arber, A. 1920. Water plants. Cambridge University Press. Arber, A. 1925. Monocotyledons. Cambridge University Press. Burström, H.G., and C. Odhnoff. 1963. Vegetative anatomy of plants. Svenska Bokförlaget, Stockholm, Sweden. Fig. 79: stem.

Campbell, G. 1936. The anatomy of Potamogeton pectinatus. Trans. Bot. Soc. Edinburgh 32:179-186.

Chrysler, M.A. 1907. The structure and relationships of the Potamogetonaceae and allied families. Bot. Gaz. 44(3):161188.

Eames, A.J., and L.H. MacDaniels. 1947. An introduction to plant anatomy. 2d ed. McGraw-Hill.

Hagström, J.O. 1916. Critical researches on the Potamogetons. Kungl. Svenska Vetenskapsakademiens Handlingar, 55(5):1281. Numerous illustrations.

Ogden, E.C. 1943. The broad-leaved species of Potamogeton of North America north of Mexico. Rhodora 45:57-105, 119-163, 171-214.

Ogden, E.C. 1953. Key to the North American species of Potamogeton. N.Y. State Mus. Circ. 31.

Ogden, E.C. 1966. Potamogetonaceae. In C.L. Lundell, Flora of Texas 1(3):369-382.

Pieters, A.J. 1901. The plants of western Lake Erie, with observations on their distribution. U.S. Fish Comm. Bull. for 1901.

Raunkiaer, C. 1903. Anatomical Potamogeton-Studies and Potamogeton fluitans. Botanisk Tidsskrift 25(3):253-280.

Sculthorpe, C.D. 1967. The biology of aquatic vascular plants. St. Martin.

Singh, V. 1964. Morphology and anatomical studies in Helobiae. I. Vegetative anatomy of some members of Potamogetonaceae. Proc. Indian Acad. Sci., Ser. B, 60(3):214-231.

\section{P. alpinus (P. tenuifolius)}

Uncommon. Cold water of lakes and streams.

Stem terete, 1-2 mm; stele trio type, having 2 patches of phloem on the inner face of the trio bundle; endodermis of O-cells; cortical bundles absent; pseudohypodermis absent.

Reference: Hagstrom, fig. 63: stem.

\section{P. amplifolius}

Common and often abundant. Lakes and streams, usually in deep water.

Stem terete, 1-3.5 $\mathrm{mm}$; stele proto type; endodermis of O-cells; cortex with interlacunar bundles present but subepidermal bundles absent; pseudohypodermis present.

\section{P. confervoides}

Uncommon. Bog pools and acid lakes.

Stem terete, less than $1 \mathrm{~mm}$; stele 1-bundled or oblong type with 1 median bundle; endodermis of O- or Ucells; cortical bundles absent; pseudohypodermis present or absent.

Reference: Hagstrom, fig. 34: stem, leaf, and peduncle.

\section{P. crispus}

Not native, but now widespread and often an abundant weed. Pools, lakes, and streams.

Stem oval, $0.5-2 \mathrm{~mm}$; stele oblong type with 1 median bundle; endodermis of O-cells; cortical bundles absent; pseudohypodermis 1 cell thick.

References: Arber 1920, fig. 40: stem. Chrysler, pl. 17: stem. HaGstrom, figs. 21, 22, 24: rhizome, stem, and leaf. OGDEN 1966, pl. 50: stem. RAUnKIAER, fig. 3: stem. SCUlthorPe, figs. 5.22, 5.23: stem. SiNGH, figs. 1, 4, 7: root and stem.

\section{P. diversifolius ( $P$. capillaceus)}

Not common, except in the Adirondacks and on Long Island. Pools, lakes, and slow streams.

Stem terete, less than $1 \mathrm{~mm}$; stele oblong type, with 1 or 2 median bundles; endodermis of O-cells; cortical bundles absent or rarely with 1 or 2 tiny ones next to the epidermis; pseudohypodermis present or absent.

\section{P. epihydrus}

Common and often abundant. Pools, lakes, and streams.

Stem oval, $0.5-2 \mathrm{~mm}$; stelar pattern variable: proto type, trio type, or oblong type with 2 median bundles; endodermis of O-cells; interlacunar bundles in the outer 
interlacunar circle; subepidermal bundles present or absent; pseudohypodermis present or absent.

References: EAMES AND MACDANIELS, fig. 139: leaf. HaGsTrom fig. 62: stem (as $P$. nuttallii).

\section{P. filiformis}

Occasional. Calcareous or brackish, mostly shallow water of lakes and streams.

Stem terete, less than $1 \mathrm{~mm}$; stele 1-bundled type or oblong type with 1 or 2 median bundles; endodermis of U-cells; presence of cortical bundles variable, interlacunar bundles may be absent or only in the outer interlacunar circle or in several circles; subepidermal bundles are usually absent; pseudohypodermis present. Anatomy of stem and peduncle similar to that of $P$. pectinatus.

Reference: HaGSTROM, fig. 4: stem and leaf.

\section{P. foliosus}

Frequent. Fresh or brackish water of lakes and streams.

Stem oval or flattened in cross section, less than $1 \mathrm{~mm}$ in longest diam; stele 1-bundled type; endodermis of O-cells; cortex with no interlacunar bundles but usually with subepidermal bundles; pseudohypodermis absent.

References: Hagstrom, fig 35: leaf and peduncle. OGden 1966, pl. 51: stem.

\section{P. friesii}

Frequent. Calcareous or brackish water of lakes and streams.

Stem flattened in cross sectioli, less than $1 \mathrm{~mm}$ in longest diam; stele 1-bundled type; endodermis of Ocells; cortex with no interlacunar bundles but with subepidermal bundles; pseudohypodermis present or absent.

\section{P. gramineus}

Common and often abundant. Lakes and streams. Stem terete, $0.5-1 \mathrm{~mm}$; stele oblong type with 1 (rarely 2) median bundle and usually only 1 lateral bundle on each side; endodermis of narrow U-cells, strongly thickened on the inner and lateral faces; cortex with interlacunar bundles strongly developed but only in the outer interlacunar circle; subepidermal bundles present or absent; pseudohypodermis absent or 1 cell thick.

References: Hagstrom, fig. 102: stem. Raunkiaer, fig. 3: stem.

\section{P. hillii}

Rare but may be locally abundant. Pools (often stagnant) and slow streams.
Stem oval or flattened in cross section, $0.5-1 \mathrm{~mm}$ in longest diam; stele 1-bundled type or oblong type with 1 median bundle; endodermis of O-cells; cortex with no interlacunar bundles but with subepidermal bundles; pseudohypodermis absent.

Reference: Hagstrom, fig. 44: leaf and peduncle.

\section{P. illinoensis $P$. angustifolius, $P$. lucens}

Common and often abundant. Lakes and streams.

Stem terete, $1.5-5 \mathrm{~mm}$; stelar pattern variable, proto type, trio type, or oblong type; endodermis of strongly developed broad U-cells; cortex with bundles strongly developed in the outer interlacunar circle and sometimes a few in the next inner circle; subepidermal bundles present or absent; pseudohypodermis absent or 1 cell thick.

References: Hagstrom, fig. 99: stem. OGden 1966, pl. 56: stem.

\section{P. lateralis}

Rare or absent in New York. Collected in Hemlock Lake, Livingston County in 1882; not seen since.

Stem terete, less than $1 \mathrm{~mm}$; stele 1-bundled type; endodermis of O-cells; cortical bundles absent; pseudohypodermis absent.

\section{P. natans}

Common and often abundant. Lakes and streams.

Stem terete, 1-2 $\mathrm{mm}$; stele trio type, with 2 patches of phloem on the inner face of the trio bundle; endodermis of strongly developed broad U-cells; cortex with strongly developed bundles throughout the interlacunar and subepidermal circles (these bundles fewer and smaller in the rhizome); pseudohypodermis 1 cell thick. Patterns of submersed leaf and emersed leaf petiole similar.

References: Arber 1920, fig. 41: root. Chrysler, pls. 15, 17: rhizome, stem, leaf, and peduncle. OGDEN 1943, pl. 747: stem. OGdEN 1953, pl. 1: stem. RAUNKIAER, figs. 1, 3: stem. Sculthorpe, figs. 5.16, 5.19, 5.22-5.25: stem. Singh, fig. 5: stem.

\section{P. nodosus (P. americanus, P. lonchites)}

Frequent to common. Lakes and streams.

Stem terete, 1-1.5 mm; stele trio type with 1 patch of phloem on the inner face of the trio bundle; endodermis of O-cells; cortical bundles absent; pseudohypodermis absent.

References: Ogden 1966, pl. 55: stem. Pieters, pl. 13: stem. 


\section{P. oakesianus}

Occasional. Ponds and slow streams.

Stem terete, $0.5-1 \mathrm{~mm}$. Anatomy as in P. natans, except interlacunar bundles in but 1 circle, pseudohypodermis sometimes absent.

\section{P. obtusifolius}

Not common. Ponds and slow streams.

Stem oval in cross section, $0.5-1 \mathrm{~mm}$; stele oblong type, with 1 or 2 median bundles; endodermis of $\mathrm{O}-$ cells; cortex with no interlacunar bundles but with subepidermal bundles; pseudohypodermis absent.

Reference: HaGstrom, fig. 51: rhizome, stem, and leaf.

\section{P. pectinatus}

Common. Alkaline or saline water.

Stem terete, less than $1 \mathrm{~mm}$; stele 1-bundled type or oblong type with 1 or 2 median bundles; endodermis of U-cells; cortex with bundles in 1, 2, or 3 interlacunar circles; subepidermal bundles usually absent; pseudohypodermis present. Peduncle less than $1 \mathrm{~mm}$, with a prominent endodermis of U-cells; 2 or more poorly developed bundles in the center and none outside the endodermis; pseudohypodermis usually 1 cell thick.

References: ARBER 1920, fig. 40: stem; fig. 41: root. Campbell, fig. 2: stem. Chrysler, pl. 16: stem. Eames and MacDaniels, fig. 139: stem. Hagstrom, fig. 16: stem and leaf. OGDen 1966, pl. 49: stem. Raunkiaer, fig. 6: leaf. Sculthorpe, fig. 5.22: stele. SingH, figs. 3, 8, 10: stem and leaf.

\section{P. perfoliatus (P. bupleuroides)}

Common. Lakes and streams.

Stem terete, $0.5-2 \mathrm{~mm}$; stele trio type, usually with 2 patches of phloem on the inner face of the trio bundle; endodermis of O-cells; cortex with no bundles; pseudohypodermis usually present as a 1-cell layer. Rhizome similar but endodermis not evident.

Reference: RAUNKIAER, figs. 2, 3: stem.

\section{P. praelongus}

Occasional. Lakes and streams, usually in deep water.

Stem terete, 1.5-4 mm; stele proto type (see pl. 13); endodermis of U-cells; cortex with many interlacunar and subepidermal bundles; pseudohypodermis 1-3 cells thick.

References: Hagstrom, fig. 116: diagram of stele. Raunkiaer, fig. 3: stem. Singh, fig. 6: stem.

\section{P. pulcher}

Rare or locally common. Shallow muddy pools and slow streams.

Stem terete, $0.5-2.5 \mathrm{~mm}$; stele proto type; endodermis of O-cells; cortex with no bundles; pseudohypodermis 1 cell thick.

References: Chrysler, pl. 16: stem and rhizome. OGDEN 1966, pl. 54: stem. SCUl thoRPE, fig. 5.22: stem and stele.

\section{P. pusillus (P. berchtoldii, P. panormitanus)}

Common and often abundant. Quiet water of pools, lakes, and slow streams.

Stem terete, less than $1 \mathrm{~mm}$; stele usually 1-bundled type but robust specimens may have the oblong type with 1 median bundle; endodermis of O-cells; cortex with no interlacunar bundles but with subepidermal bundles; pseudohypodermis absent.

References: HaGSTrom, fig. 24: stem; fig. 38: stem and leaf (as $P$. panormitanus); fig. 53: stem and leaf (as P. lacunatus); fig. 54: peduncle; fig. 55: leaf. SCUl ThOR Pe, fig. 5.22: stele. Singh, fig. 11 :' leaf.

\section{P. richardsonii}

\section{Common. Lakes and streams.}

Stem terete, 1-2.5 mm. Anatomy of stem and peduncle identical to $P$. perfoliatus.

\section{P. robbinsii}

Occasional to common; sometimes locally abundant and weedy.

Stem terete or oval, $0.5-2 \mathrm{~mm}$; stele oblong type with 1 median bundle; endodermis of O-cells; cortex with bundles in 1 or more interlacunar circles; subepidermal bundles present or absent; pseudohypodermis present or absent.

Reference: Hagstrom, fig. 19: stem and leaf.

\section{P. spirillus (P. dimorphus)}

Common. Shallow pools, lake margins, and quiet streams.

Stem terete, less than $1 \mathrm{~mm}$; stele 1-bundled type or oblong type with 1 or 2 median bundles; endodermis of O-cells; cortex with no bundles or rarely with faint ones; pseudohypodermis absent.

\section{P. strictifolius (P. rutilus)}

Frequent. Calcareous water of lakes and streams.

Stem terete to oval in cross section, less than $1 \mathrm{~mm}$ in greatest diam; stele 1-bundled type or oblong type with 1 median bundle; endodermis of O-cells; cortex with no 
interlacunar bundles but with subepidermal bundles; pseudohypodermis present or absent.

\section{P. vaginatus}

Rare. Calcareous or brackish water of lakes and streams.

Stem terete or oval, $0.5-4 \mathrm{~mm}$. Anatomy of stem and peduncle essentially the same as $P$. pectinatus.

Reference: Hagstrom, fig. 12: stem and leaf.

\section{P. vaseyi}

Occasional. Quiet water of lakes.

Stem terete, less than $1 \mathrm{~mm}$; stele 1-bundled type or oblong type with 1 median bundle; endodermis of $\mathrm{O}$ cells; cortex with no interlacunar bundles but with subepidermal bundles; pseudohypodermis absent.

Reference: HaGsTrom, fig. 59: leaf and peduncle.

\section{P. zosteriformis ( $\mathrm{P}$. compressus)}

Common. Lakes and quiet streams.

Stem strongly flattened, $1-3 \mathrm{~mm}$ in longest diam; stele oblong type with 1 median bundle; endodermis of O-cells; cortex with interlacunar bundles variable in number from many throughout to none; subepidermal bundles present; pseudohypodermis usually absent.

Reference: PIETERS, pl. 13: stem.

\section{RUPPIA}

Map 51, Plate 15

One species in New York.

Graves, A.H. 1908. The morphology of Ruppia maritima.

Trans. Conn. Acad. Arts and Sci. 14:59-170.

\section{R. maritima}

Common in suitable habitats. Shallow saline water. Rhizome, stem, leaf, and peduncle usually less than 1 $\mathrm{mm}$, lacunate. Rhizome, stem, and peduncle essentially the same, all varying in amount of lacunation. Pattern simple and similar to several other tiny stems: Potamogeton, Zannichellia, Najas, Elodea, Elatine, Callitriche, and Utricularia.

Reference: GravEs, figs. 8-10; pls. 1, 3, 4, 6: root, rhizome, stem, and peduncle.

\section{ZANNICHELLIA}

One species in New York.

Map 52, Plate 16

\section{Z. palustris}

Common. Fresh or brackish water of lakes, ditches, and slow streams.
Rhizome and stem usually less than $1 \mathrm{~mm}$. Stem with a single central bundle; cells of stele all thin walled; endodermis evident; cortex with 1 or 2 circles of large lacunae. Rhizome similar to stem but usually not lacunate. Stem pattern simple and similar to several other tiny stems: Potamogeton, Ruppia, Najas, Elodea, Elatine, Callitriche, and Utricularia.

\section{ZOSTERA}

Map 53

One species in New York.

Arber, A. 1920. Water plants. Cambridge University Press.

Chrysler, M.A. 1907. The structure and relationships of the Potamogetonaceae and allied families. Bot. Gaz. 44(3):161188.

\section{Z. marina}

Common to abundant in suitable habitats. Saline water of the ocean and Hudson River.

Stem terete to flattened, $1-3 \mathrm{~mm}$, not lacunate or with few to many lacunae (to nearly 50 percent); with 3 evident bundles. Leaves flat, lacunate, appearing somewhat stemlike at base owing to the concentric rings of leaf sheaths. Not illustrated.

References: Arber, figs. 85, 86: leaf. Chrysler, pl. 18: stem.

\section{NAJAS}

Maps 54-59, Plate 17

Seven species in New York.

Roots less than $1 \mathrm{~mm}$, scarcely lacunate. Stems mostly less than $1 \mathrm{~mm}$ and with anatomical pattern as illustrated, except for $N$. marina, which is $1-2 \mathrm{~mm}$ and scarcely or not at all lacunate. Stem pattern simple and similar to several other tiny stems: Potamogeton, Ruppia, Zannichellia, Elodea, Elatine, Callitriche, and Utricularia.

Arber, A. 1920. Water plants. Cambridge University Press. Pieters, A.J. 1901. The plants of western Lake Erie, with observations on their distribution. U.S. Fish Comm. Bull. for 1901.

\section{N. flexilis}

Common to abundant. Lakes and streams.

Reference: Pieters, figs. H, K: stem and leaf.

\section{N. gracillima}

Occasional. Shallow water of sandy lakes.

\section{N. guadalupensis}

Occasional. Shallow water of lakes. 


\section{N. marina}

Locally common. Saline water of lakes.

\section{N. minor}

Not native. Locally established in brackish and fresh water of river bays and small ponds.

Reference: ARBER, fig. 140: root.

\section{N. muenscheri}

Local. Brackish tidal margins of Hudson River.

\section{N. olivacea}

Rare. Deep water of Cayuga Lake, Seneca County. Not examined.

\section{SCHEUCHZERIA}

Map 60, Plate 18

One species in New York.

\section{S. palustris}

Frequent. Bogs, marshes, and peaty shores.

Rhizome terete, 3-5 mm; pith lacunate, surrounded by a solid ring of bundles and often with a few separate bundles internal to the ring and with a few to many smaller bundles in the lacunate cortex; stelar bundles amphivasal, as in rhizomes of Acorus and Calla. Stem terete, 1-3 mm, similar to rhizome but bundles not amphivasal, except at base. Leaf, excluding sheath, concavo-convex, 2-4 mm, highly lacunate. Peduncle $1 \mathrm{~mm}$ or less, not lacunate. Rhizome similar to that of Acorus. Stem similar to rhizome of Lysimachia. Leaf similar to petiole of Alisma and some species of Potamogeton and Sagittaria.

\section{ALISMA}

Maps 61-62, Plate 19

Two or three species in New York. Treated here as two.

Petioles variable in diam, from a few $\mathrm{mm}$ to more than 10, semiterete (above the sheathing base), 1 side flattened, with a ridge at each end of the flat side; interlacunar bundles mostly 5-9; subepidermal bundles many. Similar to petiole of Sagittaria; see also Nuphar. Submersed petioles more lacunate than emersed petioles. Peduncles about same diam as petioles, triangular with broad rounded corners to nearly terete; often not obviously lacunate, except for pith area which becomes hollow. Young peduncles at base may be lacunate between epidermis and ring of bundles. This delicate tissue becomes crushed and folded and the lacunation becomes less up the peduncle until none. The peduncle is somewhat similar to the stem of Cladium.
Björkqvist, I. 1967. Studies in Alisma L. I. Distribution, variation and germination. Opera Botanica, No. 17.

Stant, M.Y. 1964. Anatomy of the Alismataceae. J. Linn. Soc. (Bot.) 59(376):1-42.

A. gramineum (A. geyeri)

Uncommon. Shallow water and mud.

Petiole similar to $P$. plantago-aquatica, but with fewer and larger lacunae and only 5 interlacunar bundles. Peduncle 1-2 $\mathrm{mm}$.

Reference: BJORKQVIST, fig. 11: petiole.

A. plantago-aquatica (A. subcordatum, A. triviale)

Common. Marshes, muddy shores, and ditches. Considered by many to include two species.

References: BJORKQVist, fig. 10: petiole. Stant, figs. 53, 54, 57-59, 61: root, petiole, and peduncle (as A. plantago).

\section{SAGITTARIA}

Maps 63-70, Plates 20-21

Eight or nine species in New York.

Anatomical patterns of roots, rhizomes, petioles, and peduncles similar to the illustrations, except that the smaller species have fewer bundles. Sizes, shapes, and amount of lacunation vary somewhat according to the part of the plant organ that is chosen. Petioles vary from plano-convex at base to sharply triangular above. Similar to petioles of Alisma. Peduncles circular to triangular.

Arber, A. 1925. Monocotyledons. Cambridge University Press. Figs. 57, 59, 84: leaf.

Stant, M.Y. 1964. Anatomy of the Alismataceae. J. Linn. Soc. (Bot.) 59(376):1-42. Figs. 6-50: root and leaf.

\section{S. calycina (Lophotocarpus c., L. spongiosus)}

Rare. Brackish ponds, sloughs, and marshes. Peduncle 1-3 mm. Not examined.

\section{S. cuneata}

Occasional. Mud or shallow quiet water of ponds, sloughs, and marshes. Peduncle 1-2 mm.

S. eatonii ( $S$. graminea, in part)

Rare. Tidal river mud and sand. Considered by some to be a distinct species, by others merely a tidewater variant of $S$. graminea. Not examined.

\section{S. engelmanniana}

Frequent on Long Island. Acid shallow water of sandy ponds. Peduncle 1-3 mm. Not examined. 


\section{S. graminea}

Frequent to locally abundant. Peduncle 1-2 mm.

\section{S. latifolia}

Common to abundant. Shallow water of mud of ponds, marshes, and bogs. Peduncle $1-10+\mathrm{mm}$.

\section{S. rigida}

Common to locally abundant. Shallow to deep water of ponds and marshes. Peduncle 1-5 mm.

\section{S. subulata}

Local. Fresh to brackish tidal mud. Peduncle \pm 1 $\mathrm{mm}$, with large lacunae.

\section{S. teres}

Rare. Shallow water of sandy ponds in Suffolk County. Peduncle 1-2 mm, with large lacunae.

Reference: ARBER, fig. 84: leaf.

\section{BUTOMUS}

Map 71, Plates 22-23

One species in New York.

Arber, A. 1925. Monocotyledons. Cambridge University Press. Fahn, A. 1967. Plant anatomy. Pergamon.

Stant, M.Y. 1967. Anatomy of the Butomaceae. J. Linn. Soc. (Bot.) 60(381):31-60.

\section{B. umbellatus}

Locally common. Shallow to deeper water with muddy or silty bottom.

Root 1-2 mm, with a circle of lacunae in the outer portion; there is a single xylem element in the center. Rhizome mostly more than $10 \mathrm{~mm}$, scarcely lacunate. Leaf $5-10+\mathrm{mm}$, strongly 3 -angled above, sheathing at base. Peduncle (scape) 3-6 mm, lacunate in the central area; pedicel $1 \mathrm{~mm}$ or less, not lacunate when young, becoming lacunate in the central area with age.

References: ARBER, fig. 2: root. FAHN, fig. 96: leaf. Stant, figs. 33-39, 51, 54, 70: root, leaf, and peduncle.

\section{ELODEA}

Three species in New York.

Roots less than $1 \mathrm{~mm}$, not lacunate. Stems terete, 1-3 mm, with 1 or more circles of lacunae; cortical bundles present or absent. Stem pattern simple and similar to several other tiny stems: Potamogeton, Ruppia, Zannichellia, Najas, Elatine, Callitriche, and Utricularia. Peduncles less than $1 \mathrm{~mm}$, with 3 large lacunae.

Hulbary, R.L. 1944. The influence of air spaces on the threedimensional shapes of cells in Elodea stems, and a comparison with pith cells of Ailanthus. Amer. J. Bot. 31:561-580.
E. canadensis (Anacharis c., Philotria c.)

Common and often an abundant weed, especially in alkaline water.

E. densa (Anacharis d., Philotria d.)

This is the common aquarium and laboratory "elodea " that is found occasionally as an introduction and persists in some areas of Long Island.

Reference: Hulbary, fig. 40: stem.

E. nuttallii (Anacharis n., A. occidentalis, Philotria n., P. o.)

Frequent. Fresh, usually acid or slightly brackish water.

\section{VALLISNERIA}

Map 74, Plate 25

One species in New York.

Arber, A. 1920. Water plants. Cambridge University Press.

\section{V. americana (V. spiralis)}

Common and often abundant. Quiet water of ponds and slow streams, usually with muddy bottom or of sand and coarse silt.

Anatomical patterns of male and female plants the same. Root less than $1 \mathrm{~mm}$; stele tiny, simple, with a single central channel and a few surrounding cells; cortex with 1 circle of lacunae. Rhizome or stolon terete, 2-4 mm; peduncle terete: male $0.5-1 \mathrm{~mm}$, female $1.5-3$ $\mathrm{mm}$. Fruit terete, $3-5 \mathrm{~mm}$, wall slightly to nearly 50 percent lacunate.

Reference: ARBER, fig. 139: root.

\section{CAREX}

Maps 75-80, Plate 26

Many species in New York, whose stems (culms) may be somewhat lacunate at base.

Stems sharply triangular above, bluntly triangular below, less than 1-5 mm (excluding enveloping sheaths); bundles in 1 or 2 circles; lacunae small to large, usually covering less than 50 percent of the area, alternating with the outer circle of bundles; central tissue spongy or with large cavities. Stem similar to Eriophorum but more evidently triangular. A few species whose stems approach 50 percent lacunation are listed here; others may be similar.

Metcalfe, C.R. 1971. Anatomy of the monocotyledons. Vol. 5. Cyperaceae. Clarendon Press, Oxford, England.

\section{C. aquatilis (C. substricta)}

Frequent. Shallow water of cold lakes and streams and in bogs and swamps. 
Stem triangular, 1-3 mm. Bundles mostly not contiguous; large ones in a single ring. Lacunae peripheral, in a single circle with smaller bundles between. Pith spongy, becoming partly hollow. The enveloping sheaths are highly lacunate, somewhat similar to those of Scirpus and Cladium.

\section{C. comosa}

Frequent to common. Shallow water of lakes and swamps.

Stem 2-4 $\mathrm{mm}$, similar to $C$. aquatilis but lacunae usually larger.

\section{C. lasiocarpa}

Frequent to common. Wet soil to shallow water.

Stem 1-2 mm, similar to C. comosa, but usually with 2 distinct circles of large bundles at the base of the stem.

\section{C. limosa}

Frequent. Bogs and marshes.

Stem mostly less than $1 \mathrm{~mm}$. Pattern similar to $C$. comosa, but nearly all bundles are between the lacunae.

\section{C. rostrata (C. inflata)}

Common. Wet shores, marshes, and swamps.

Stem 1-2 mm (except the spongy base may be up to $15 \mathrm{~mm}$ ). Similar to $C$. comosa.

\section{C. vesicaria}

Common. Wet meadows, marshes, and swamps. Stem 1-2 mm, similar to C. lasiocarpa.

\section{CLADIUM}

Map 81, Plate 27

One species in New York.

Metcalfe, C.R. 1971. Anatomy of the monocotyledons. Vol. 5. Cyperaceae. Clarendon Press, Oxford, England.

Plowman, A.B. 1906. The comparative anatomy and phylogeny of the Cyperaceae. Ann. Bot. 20:1-33.

\section{C. mariscoides (Mariscus m.)}

Common to locally abundant. Fresh or brackish water of marshes and lake shores.

Rhizome terete, with large marginal lacunae. Stem terete to slightly triangular, mostly $1-3 \mathrm{~mm}$; similar to rhizome but with smaller marginal lacunae; somewhat similar to stem of Eriophorum and peduncle of Alisma. The connate lacunate sheath in freehand sections may appear to be a part of the stem. The sheath alone is similar to the main stem of Equisetum hyemale. Leaf horseshoe-shaped at lower portion to nearly terete above, 1-3 mm, highly lacunate. Peduncle scarcely or not lacunate.

Reference: Plowman, fig. 18: rhizome.

\section{CYPERUS}

Map 82

More than 15 species in New York. One of them, at least, with small lacunae when growing in water, but not covering 50 percent of the area. Not illustrated.

Metcalfe, C.R. 1971. Anatomy of the monocotyledons. Vol. 5. Cyperaceae. Clarendon Press, Oxford, England.

\section{C. esculentus}

Stem triangular, 1-4 mm. Similar to Scirpus americanus but lacunae much smaller and mostly separated by single-cell chains.

\section{DULICHIUM}

Map 83, Plate 28

One species in New York.

Plowman, A.B. 1906. The comparative anatomy and phylogeny of the Cyperaceae. Ann. Bot. 20:1-33.

\section{D. arundinaceum}

Common. In shallow water and wet shores of ponds, streams, marshes, and bogs.

Rhizome not lacunate, but may develop a circle of small lacunae. Stem terete or nearly so, 2-5 mm; central area very large, soon becoming hollow; outer area with 2 circles of bundles and 1 circle of lacunae; similar to the main stem of Equisetum hyemale and also to some species of Juncus. Peduncle scarcely or not lacunate.

Reference: Plowman, figs. 13, 14: stem.

\section{ELEOCHARIS} Maps 84-104, Plate 29

About two dozen species in New York, of which nine or ten are common and widespread.

Roots not lacunate when young, but in age the cortex breaks down to radial rows of trapezoidal lacunae. Rhizomes variable owing to age and perhaps species. In general there is a ring of bundles, which is discontinuous or continuous, surrounding a small area of parenchyma cells when young. The endodermis is evident. The large cortex is nonlacunate when young, breaking to radially elongated lacunae in age. Stem (scapes) terete or with 3-8 angles; patterns similar among the species but appearing much unlike the rhizomes; central area (inner cortex) very large, with large lacunae; vascular bundles 
in a discontinuous ring between the inner and outer cortex; outer cortex of 1 or 2 layers (circles) of palisadeshaped cells, with secretory cells usually evident; epidermal bundles present, these are tiny bundles of fibers separating cells of the epidermis and about the size of, or a little larger than, an epidermal cell. There is some variation with habitat, but the general patterns are the same among the species examined.

Metcalfe, C.R. 1971. Anatomy of the monocotyledons. Vol. 5. Cyperaceae. Clarendon Press, Oxford, England.

Plowman, A.B. 1906. The comparative anatomy and phylogeny of the Cyperaceae. Ann. Bot. 20:1-33.

\section{E. acicularis}

Common and often abundant. Damp soil, muddy shores, and shallow water. Stem much less than $1 \mathrm{~mm}$, similar to the larger species but with only a few bundles.

\section{E. ambigens}

Rare. Wet ground in Suffolk County. Stem $\pm 1 \mathrm{~mm}$. Not examined.

E. annua (E. ovata in part)

Common. Wet soil of marshes and lake shores. Stem terete, $\pm 1 \mathrm{~mm}$.

E. compressa (E. acuminata)

Occasional. Marshes and shores. Stem $\pm 1 \mathrm{~mm}$ or less. Not common, but can be distinguished from most other species of the genus by the compressed stem.

E. diandra (E. ovata in part)

Local. River and lake silt. Stem $\pm 1 \mathrm{~mm}$.

E. elliptica (E. capitata, E. tenuis)

Common. Wet soil. Stem $\pm 1 \mathrm{~mm}$ or less.

\section{E. engelmannii}

Rare. Wet soil and muddy shores. Stem $\pm 1 \mathrm{~mm}$.

\section{E. equisetoides (E. interstincta)}

Rare. Shallow water. Stem 4-5 mm; pith very large, soon becoming hollow; cortex with a single circle of large bundles alternating with a single circle of large lacunae. Somewhat similar to the sheath of Cladium. If fragment of stem is sufficiently long, this species can be recognized by the cross septations which are $\pm 2-5 \mathrm{~cm}$ apart.

E. erythropoda (E. calva, E. glaucescens)

Common. Marshy and muddy places and lake shores. Stem $\pm 1 \mathrm{~mm}$ or less.
E. halophila (E. uniglumis of New York reports)

Rare. Saline or brackish shores. Stem $\pm 1 \mathrm{~mm}$. Not examined.

E. intermedia (E. reclinata)

Frequent. Wet soil, marshes, and shallow ponds. Mostly less than $1 \mathrm{~mm}$.

\section{E. melanocarpa}

Rare. Wet sandy soil, Suffolk County; reported from Staten Island. Stem 1-2 mm.

\section{E. obtusa}

Common to abundant. Wet soil and muddy shores. Stem 1-2 mm.

\section{E. olivacea (E. flavescens)}

Occasional. Wet sands, peats, and muddy shores. Stem $\pm 1 \mathrm{~mm}$ or less.

\section{E. palustris}

Common. Shallow water of lakes, marshes, and slow streams. Stem 1-3 mm.

Reference: Plowman 1906, figs. 12, 19, 20: rhizome, stem, and peduncle.

\section{E. parvula (Scirpus nanus)}

Rare. Wet saline soil. Stem less than $1 \mathrm{~mm}$. Not examined.

\section{E. quadrangulata (E. mutata)}

Rare. Shallow water of sandy ponds and peaty shores. Stem square, 3-5 mm, strongly lacunate with large lacunae having bundles on the otherwise 1-cell-wide chains of cells between the lacunae. It may be distinguished from most other species of the genus by its large 4-angled stem.

E. quinqueflora (E. pauciflora, Scirpus pauciflorus) Rare and local. Wet or boggy soil. Mostly less than $1 \mathrm{~mm}$.

\section{E. robbinsii}

Rare. Shallow water and mud. Stem triangular, 1-2 $\mathrm{mm}$. Can be distinguished from most other species of the genus by the 3 -angled stem.

\section{E. rostellata}

Occasional or locally common. Saline and calcareous marshes and wet meadows. Stem $\pm 1 \mathrm{~mm}$. 
E. smallii (E. palustris in part)

Common. Shallow water and margins of ponds and stream in sandy or peaty soils. Stem $1-4 \mathrm{~mm}$.

E. tenuis (E. capitata in part)

Rare. Wet or dryish sand and peat. Stem 4-8-angled, these angles often obscure on freehand cut sections, \pm 1 $\mathrm{mm}$.

E. tortilis (E. simplex)

Rare, one location in Nassau County. Wet soil. Stem sharply 3 -angled, $\pm 1 \mathrm{~mm}$. Not examined.

\section{E. tricostata}

Rare. One location in Suffolk County. Wet sandy or peaty soil. Stem compressed or subterete. Not examined.

\section{E. tuberculosa}

Rare. Wet sandy soil. Stem oval, $\pm 1 \mathrm{~mm}$.

\section{ERIOPHORUM}

Maps 105-107, Plate 30

Six or seven species in New York. Six are frequent to common in bogs. Stems usually with a single circle of lacunae mostly alternating with the bundles. Somewhat similar to the stem of Cladium and to the peduncle of Alisma; also to some species of Carex. Patterns similar among the species, but there is great variation as to amount of lacunation and thickness of tissue between the lacunae.

Metcalfe, C.R. 1971. Anatomy of the monocotyledons. Vol. 5. Cyperaceae. Clarendon Press, Oxford, England.

E. alpinum (Scirpus hudsonianus)

Scarcely lacunate.

Reference: MEtCALFE, fig. 61: stem.

\section{E. angustifolium}

Rare or absent in the State.

Reference: Metcalfe, fig. 34: leaf.

\section{E. gracile}

Stem 1-2 mm, lacunate.

\section{E. tenellum}

Lacunate but less than $1 \mathrm{~mm}$.

E. vaginatum (E. callitrix, E. spissum)

Frequent in open bogs in the northern part of the State. Representative of the usual pattern.

\section{E. virginicum}

Scarcely lacunate.

E. viridi-carinatum

Stem 1-3 mm, lacunate.

\section{FUIRENA}

$$
\text { Map 108, Plate } 26
$$

One species in New York.

Metcalfe, C.R. 1971. Anatomy of the monocotyledons. Vol. 5. Cyperaceae. Clarendon Press, Oxford, England.

\section{F. pumila (F. squarrosa)}

Not common. Wet meadows and marshes.

Rhizome absent. Stem subterete, 1-3 mm. Vascular bundles in a circle near the epidermis and also scattered in the central area. Lacunae in the central area large and separated by 1-cell-wide chains of cells when young, these collapsing in age to slender strands and losing the cellular appearance. Somewhat similar to Eleocharis (which lacks bundles in the central area) and teretestemmed Scirpus (which is usually larger and with bundles more numerous).

\section{RHYNCHOSPORA}

Maps 109-112, Plate 31

Several species in New York, of which four are common enough to be considered here.

Stem subterete at base, 1-2 mm, not lacunate or with the area surrounding the solid bundle ring slightly to highly lacunate, becoming triangular and less lacunate above. Similar to Eriophorum but the lacunae usually smaller and more numerous; also to Lysimachia.

\section{R. alba}

Frequent. Bogs and marshes.

\section{R. capillacea}

Local. Marly bogs and wet limestone.

\section{R. fusca}

Frequent to common. Bogs, marshes, and lake shores.

R. glomerata (R. capitellata)

Locally common. Wet soil.

SCIRPUS

Maps 113-122, Plates 32-33

About two dozen species in New York, of which some (bulrushes) are highly lacunate and are included here; 
others (woolgrasses) growing in water or wet soil may be similar.

Stems variable in size and shape, terete to triangular; vascular bundles usually embedded in the ground tissue but the outermost often at the boundary between the chlorenchyma and ground parenchyma. Rhizomes terete, even with triangular-stemmed species, lacunate but less so than the stem. Peduncles scarcely or not at all lacunate. Patterns of the rhizomes somewhat similar to the stems of Sparganium. Patterns of the terete stems somewhat similar to Calla, Peltandra, and Pontederia.

Kaul, R.B. 1971. Diaphragms and aerenchyma in Scirpus validus. Am. J. Bot. 58:808-816.

Levardsen, N.O. 1960. Bulrushes, hard or soft stem. Turtox News 38(8):204-205.

Metcalfe, C.R. 1971. Anatomy of the monocotyledons. Vol. 5. Cyperaceae. Clarendon Press, Oxford, England. Figs. 61, 62: stem.

Plowman, A.B. 1906. The comparative anatomy and phylogeny of the Cyperaceae. Ann. Bot. 20:1-33. Pls. 1, 2.

Smith, S.G. 1969. Natural hybridization in the Scirpus lacustris complex in north central United States. Pages 175-200 in J.E. Gunckel, ed. Current topics in plant science. Academic Press, New York.

\section{S. acutus}

Common and often abundant. Shallow water of lakes and marshes.

Stem terete, 1-10 mm, similar to $S$. validus. Although fresh stems of $S$. acutus are obviously more firm than those of $S$. validus (determined by squeezing), no anatomical characters were detected to cause it.

References: LevardSEN: basal sheath. SMITH, fig. 1: stem.

\section{S. americanus}

Common. Shallow water and sandy or muddy shores. Most frequent in alkaline, brackish, or saline water.

Stem sharply triangular, $1-5 \mathrm{~mm}$.

\section{S. fluviatilis}

Common. Shallow, usually calcareous water of lakes, marshes, and streams.

Stem terete, $3-10+\mathrm{mm}$. Pattern similar to that of $S$. validus but lacunae smaller and more numerous.

\section{S. heterochaetus}

Local. Shallow water of lakes.

Stem terete, $3-10+\mathrm{mm}$. Pattern similar to stem of S. validus.

Reference: SмIтH, fig. 2: stem.

\section{S. olneyi}

Not common. Salt marshes.

Stem sharply 3-angled with concave sides, $4-8 \mathrm{~mm}$, highly lacunate.

\section{S. rubrotinctus}

Common. Marshes and swamps.

Stem terete, 3-6 mm. Pattern similar to $S$. validus but less lacunate.

\section{S. smithii}

Not common. Sandy or muddy lake shores.

Stem terete, $\pm 1 \mathrm{~mm}$, highly lacunate; similar to stem of Fuirena.

\section{S. subterminalis}

Frequent. Sluggish water of lakes, bogs, and slow streams.

Stem terete, $\pm 1 \mathrm{~mm}$, scarcely lacunate.

\section{S. torreyi}

Frequent to locally common. Shallow lakes, marshes, and borders of fresh to brackish ponds and sloughs.

Stem sharply triangular, 1-4 mm, similar to $S$. americanus.

\section{S. validus}

Common and often abundant. Shallow water of lakes, marshes, and slow streams.

Stem terete, $2-10+\mathrm{mm}$, highly lacunate. See note under $S$. acutus.

References: KaUL, fig. 2: stem and sheath. LEVARDSEN: basal sheath. SMITH, fig. 1: stem.

\section{ACORUS}

Map 123, Plate 34

One species in New York.

Kaplan, D.R. 1970. Comparative foliar histogenesis in Acorus calamus and its bearing on the phyllode theory of monocotyledonous leaves. Amer. J. Bot. 57:331-361.

Molisch, H. 1954. Anatomie der Pflanze. Gustav Fischer, Jena, E. Germany.

Sculthorpe, C.D. 1967. Biology of aquatic vascular plants. St. Martin.

\section{A. calamus}

Common and often abundant. Shallow water of marshes and slow streams.

Root 1-2 mm; stele with 5-10 large xylem elements and several smaller ones; pith usually evident but may disappear with enlargement of the xylem; endodermis usually evident; cortex without bundles. Rhizome more 
than $10 \mathrm{~mm}$; bundles amphivasal (xylem surrounds the phloem) as in rhizomes of Calla and Scheuchzeria. Peduncle (scape) narrowly to broadly triangular, 3-10+ $\mathrm{mm}$; bundles scattered throughout, not amphivasal (except an occasional small one); all of the large bundles and many small ones completely surrounded by a strong fiber sheath. Leaf (spathe) lenticular; with 3 or more bundles, not amphivasal, these sometimes scarcely evident.

References: Kaplan, figs. 53, 54: leaf. Molisch, fig. 125: root. SCUlTHORPE, fig. 6.9: root.

\section{CALLA}

Map 124, Plate 35

One species in New York.

\section{C. palustris}

Common and often abundant. Shallow, mucky water of bogs and marshes.

Root less than $1 \mathrm{~mm}$. Stem (rhizome) terete, 5-10 $\mathrm{mm}$, with scattered bundles, many of them partly or completely amphivasal (xylem surrounds the phloem) as in rhizomes of Acorus and Scheuchzeria. Petiole similar to stem, terete or semicircular. Peduncle (scape) similar to stem, terete or somewhat cordate, $2-5 \mathrm{~mm}$. Bundles of petiole and peduncle not amphivasal. Patterns of stem, petiole, and peduncle somewhat similar to stem of some species of Scirpus, stem of Pontederia, petiole of Peltandra, and peduncle of Nuphar.

\section{ORONTIUM}

Map 125

One species in New York.

\section{O. aquaticum}

Rare to occasional. Shallow water of sandy, muddy, or peaty swamps, ponds, and quiet streams.

Petiole mostly $3-5 \mathrm{~mm}$ but broader at base because of the sheath. Peduncle mostly 3-6 mm. Patterns of petiole and peduncle essentially the same and similar to that of Calla but without amphivasal bundles. Not illustrated.

\section{PELTANDRA}

Map 126, Plate 36

One species in New York.

\section{P. virginica}

Common in some areas, rare in others. Marshes, lake shores, and quiet streams.
Root 3-6 mm, similar to those of Acorus and Calla, but larger. Rhizome more than $10 \mathrm{~mm}$. Petiole terete or nearly so above, terete below except for sheath extensions, 5-10+ $\mathrm{mm}$; bundles scattered in the interlacunar areas; pattern similar to stem of Calla, Pontederia, some species of Scirpus, and peduncle of Nuphar. Peduncle terete, $5-10+\mathrm{mm}$; pattern same as petiole.

\section{ERIOCAULON}

Maps 127-128, Plate 37

Two species in New York.

Roots less than $1 \mathrm{~mm}$, lacunation variable in amount. Rhizomes not lacunate. Leaves flat, 0.5-1 x 1-4 mm, with 3-9 large lacunae. Peduncles (scapes) terete, with 4-7 low angles, $\pm 1 \mathrm{~mm}$; with 4-7 large lacunae, these separated by partitions that are several cells wide.

Tomlinson, P.B. 1969. Anatomy of the monocotyledons. Vol.

3. Commelinales - Zingiberales. Clarendon Press, Oxford, England. Figs. 32, 33, 35, 38: leaf and peduncle.

\section{E. parkeri}

Local. Tidal mud flats and shallow water of estuaries in the Hudson River. Similar to E. septangulare but peduncle with fewer lacunae.

\section{E. septangulare}

Common and often abundant. Shallow to deep water of lakes and slow streams.

Peduncle with 6 or 7 large lacunae and, alternating with these, 6 or 7 low angles; upon drying, these angles become more pronounced.

\section{HETERANTHERA}

Maps 129-130, Plate 38

Two species in New York.

Roots less than $1 \mathrm{~mm}$, becoming lacunate in outer cortex. Stems terete, $2-6 \mathrm{~mm}$. Leaves variable.

\section{H. dubia (Zosterella d.)}

Common, often abundant and weedy. Shallow to deep quiet water of streams and lakes.

Stem 2-4 mm. Leaf with no petiole; blade flat. Peduncle seldom produced in New York, less than $1 \mathrm{~mm}$, scarcely lacunate, except for pith which has 1-3 hollow areas; lower portion enclosed by two connate sheaths.

\section{H. reniformis}

Rare. Mud and shallow water of tidal Hudson River.

Stem 3-6 mm, similar to $H$. dubia but larger. Petiole terete, oval, or plano-convex, 1-3 $\mathrm{mm}$, with a large hollow central area surrounded by a highly lacunate ring, with 10-15 large bundles and several small ones. Peduncle not examined. 


\section{PONTEDERIA}

Map 131, Plate 39

One species in New York.

Eames, A.J., and L.H. MacDaniels. 1947. An introduction to plant anatomy. 2d ed. McGraw-Hill.

\section{P. cordata}

Common and often abundant. Shallow water of marshes and lakes.

Root 1-2 mm; stele with several large conducting elements (vessels); endodermis evident; cortex next to the stele, not lacunate but of closely packed, round, thick-walled cells, outer cortex becoming highly lacunate with cells that are elongate or in the shape of a cross, these eventually appearing as radial lines; epidermis of one layer of cells. Stem, petiole, and peduncle similar to each other, terete or nearly so, from a few $\mathrm{mm}$ to more than $10 \mathrm{~mm}$; pith area soon becoming hollow; cortex highly lacunate. Young stem similar to stem of Calla and some species of Scirpus, to the petiole of Peltandra, and the peduncle of Nuphar.

Reference: EAMES AND MACDANIELS, fig. 184: submersed leaf.

\section{JUNCUS}

Maps 132-142, Plates 40-41

Thirty-two species in New York. Most of these are not sufficiently lacunate to be included here. The stems and leaves may have continuous cells or have a few lacunae or have one large lacuna which simulates a hollow pith. In J. effusus, the central area of the stem is composed of lobed cells joined to create numerous tiny lacunae (pl. 41). These cells break down in age to form a large central hollow lacuna. Stems of some other species have a nonlacunate central area (but sometimes with a partially hollow pith) and a lacunate surrounding area (pl. 40). Those known to have lacunate stems or to grow in water in the State are listed and mapped.

Cutler, D.F. 1969. Anatomy of the monocotyledons. Vol. 4. Juncales. Clarendon Press, Oxford, England. Many illustrations, mostly diagrams.

Korsmo, E. 1954. Anatomy of weeds. Grondahl \& Sons, Oslo, Norway. Pl. 17: root, rhizome, and stem.

J. acuminatus (J. paradoxus)

Frequent to common. Wet soil and marshes.

Stem 1-3 mm; pattern similar to J. articulatus; cortex lacunate; pith solid or partly hollow.

J. $\operatorname{arcticus~(J.~balticus)~}$

Locally abundant. Marshes and sandy lake shores.

Stem $\pm 1 \mathrm{~mm}$; not lacunate; pith hollow or with loose strands of cells.

\section{J. articulatus}

Frequent. Wet places.

Stem 1-3 mm; cortex lacunate; pith solid.

Reference: Cutler, fig. 6: stem and leaf.

\section{J. brevicaudatus}

Wet places. Frequent to common.

Stem 1-3 mm, not lacunate, except for a circle of small lacunae near the outer edge; pith usually hollow.

\section{J. canadensis}

Marshy places. Frequent to common.

Stem 1-3 mm; not lacunate; pith hollow or essentially so.

\section{J. effusus}

Common and often abundant. Wet meadows, swales, and marshes.

Stem 2-5 mm. Our only species of the genus with abundant distinctively lobed pith cells. Portion above inflorescence identical to stem.

Reference: Korsmo, figs. 39, 40: rhizome, stem, and leaf.

\section{J. filiformis}

Common in the Adirondacks, local elsewhere. Wet soil, margins of lakes, streams, and bogs.

Stem $1 \mathrm{~mm}$ or less; scarcely lacunate, but may have a circle of small lacunae near the outer edge; pith $\pm 1 / 2$ diam of stem, becoming hollow in age.

\section{J. militaris}

Not common. Shallow water of lakes and streams.

Stem 2-5 mm; anatomical pattern similar to J. articulatus but central area mostly hollow; lacunae vary in size and number from none in the emersed part to highly lacunate in the submersed part.

\section{J. nodosus}

Frequent to common. Wet places.

Stem 1-2 mm; scarcely lacunate, but often with small lacunae near the outer edge; pith becoming hollow.

\section{J. pelocarpus}

Locally common. Shores and shallow water of lakes and streams.

Stem $\pm 1 \mathrm{~mm}$; pattern similar to $J$. articulatus.

\section{J. torreyi}

Not common. Shores and shallow water.

Stem 1-2 mm; not lacunate; pith of round cells, usually mostly hollow. 


\section{RUMEX}

Map 143

Only one or two of the New York species are found in water. Not illustrated.

Korsmo, E. 1954. Anatomy of weeds. Grondahl \& Sons, Oslo, Norway. Figs. 50-58, pls. 25-27: root, stem, and petiole.

Metcalfe, C.R., and L. Chalk. 1950. Anatomy of the dicotyledons. Vol. 2. Clarendon Press, Oxford, England. Fig. 265: diagrams of stem and petiole.

\section{R. verticillatus}

Frequent or occasional. Wet soil or shallow water of swamps and lakes.

Stem angular-terete, 3-10 mm, sometimes lacunate, especially in the pith area which becomes hollow with age; bundles in a ring which is continuous or nearly so; pith large and without bundles; somewhat similar to stem of Armoracia. Petiole plano-convex to lenticular, 2-3 mm; mesophyll lacunate; similar to petiole of Alisma.

\section{SALICORNIA}

Map 144

Three species in New York.

Stems 1-5 mm. These not lacunate except that, when very young, the stems may have 4 large lacunae in the central portion, which become a single lacuna (hollow pith) with age. The cortex has large water storage cells and sometimes also lacunae. Not illustrated.

Fahn, A. 1967. Plant anatomy. Pergamon. Fig. 86: stem.

\section{S. bigelovii}

Salt marshes. Long Island and Staten Island.

\section{S. europaea}

Common in salt marshes.

S. virginica (S. perennis)

Salt marshes. Long Island and Fisher's Island.

\section{BRASENIA}

Map 145, Plate 42

One species in New York.

\section{B. schreberi}

Common to locally abundant. Ponds and slow streams.

Stem terete or nearly so, $2-3 \mathrm{~mm}$. Petiole terete or oval, 1-2 mm. Peduncle terete, $\pm 2 \mathrm{~mm}$, usually with 3 or 4 simple bundles but may have 2 double bundles as in the stem. Star-shaped or branched idioblasts, as seen in some genera of this family (Nymphaeaceae), not seen in Brasenia schreberi; however, large mucilaginous cells may project into the lacunae and rhombic crystals may occur in and on the surface of any of the tissues. Stem, petiole, and peduncle similar to those in Cabomba.

\section{САВОМВА}

Map 146, Plate 43

One species in New York.

\section{C. caroliniana}

Not native but introduced into ponds in some localities where it has become locally abundant.

Rhizome and stem with the same pattern and similar in size, shape, and pattern to that of Brasenia. Petiole $\pm 1 \mathrm{~mm}$, slightly to strongly lacunate, with double bundles. Peduncle $\pm 1 \mathrm{~mm}$, with 2 or 3 bundles. Idioblasts apparently absent.

\section{NELUMBO}

Map 147

One species in New York. Not illustrated.

\section{N. lutea (N. pentapetala)}

Rare. Lakes.

Rhizome (not examined) said to have a stele with numerous vascular bundles in a concentric ring and with an evident endodermis. Petiole terete, $2-5 \mathrm{~mm}$. Peduncle terete, $4-8 \mathrm{~mm}$. Anatomical patterns of petiole and peduncle essentially the same; pith area hollow, surrounded by a ring of bundles; some of the bundles are normal with phloem on the epidermal side of the xylem, others have the phloem on the pith side of the xylem; cortical lacunae very large and in one circle, except for a few small ones; stellate idioblasts apparently are absent, but cluster crystals may be present.

\section{NUPHAR}

Map 148, Plate 44

One species in New York; sometimes treated as three or four species.

Metcalfe, C.R., and L. Chalk. 1950. Anatomy of the dicotyledons. Vol. 1. Clarendon Press, Oxford, England.

N. luteum ( $N$. advena, $N$. microphyllum, $N$. rubrodiscum, N. variegatum, Nymphaea a., Ny. m., Ny. r.)

Common. Shallow to deeper water of bog pools, lakes, marshes, and slow streams.

Root 1-3 mm, similar to Nymphaea. Rhizome $5 \mathrm{~mm}$ (ssp. pumilum) to several $\mathrm{cm}$, with scattered small lacunae in a reticulate pattern; bundles distributed irregularly. Petiole triangular, plano-convex, or oval, 2$10+\mathrm{mm}$ in longest diam, with scattered simple bundles. Peduncle terete, $3-10+\mathrm{mm}$. Star-shaped or branched 
idioblasts are common in petiole and peduncle. Vascular bundles in petiole and peduncle have phloem on only 1 side of the xylem canal; in contrast with those of Nymphaea, some of which have phloem on 2 sides. The peduncle pattern is somewhat similar to the scape of Calla, petiole and peduncle of Peltandra and young stem of Pontederia. However, the star-shaped idioblasts distinguish it from these genera.

Reference: Metcalfe and Chalk, fig. 19: petiole.

\section{NYMPHAEA}

Maps 149-150, Plate 45

Two species in New York; treated as one by some authors.

Root 2-5 mm, endodermis absent. Rhizome usually more than $10 \mathrm{~mm}$, less than 50 percent lacunate. Petiole $2-10 \mathrm{~mm}$, with simple and double bundles. $\mathrm{Pe}-$ duncle $3-8 \mathrm{~mm}$, similar to petiole. Idioblasts of various shapes are frequently seen in petiole and peduncle. Vascular bundles in petiole and peduncle occur as singles (phloem on 1 side of xylem canal) and doubles (phloem on 2 sides of xylem canal) in contrast with those of Nuphar, which are all single. Patterns distinctive and not easily confused with other genera.

Conard, H.S. 1905. The waterlilies. A monograph of the genus Nymphaea. Carnegie Institution of Washington, Washington, D.C.

Sculthorpe, C.D. 1967. The biology of aquatic vascular plants. St. Martin. Figs. 5.16, 5.17, 5.21: petiole.

Williams, G.R. 1970. Investigations in the white waterlilies (Nymphaea) of Michigan. Mich. Bot. 9:72-86. Fig. 10: petiole.

\section{N. odorata (Castalia o.)}

Common to locally abundant. Shallow to deeper water of bog pools, sloughs, and ponds.

Reference: CoNARD, figs. 8, 26: root, petiole, and peduncle.

\section{N. tuberosa (Castalia t.)}

Frequent to common. Lakes and slow streams.

Reference: CONARD, fig. 26: petiole and peduncle.

\section{CERATOPHYLLUM Maps 151-152, Plate 46}

Two species in New York.

Roots absent. Stems 0.5-2 mm; scarcely lacunate; with a small central xylem canal and tiny cortical lacunae in a single circle in the inner cortex (these lacunae are usually larger than shown in the illustration); endodermis sometimes evident. Leaves less than $1 \mathrm{~mm}$. Arber, A. 1920. Water plants. Cambridge University Press.
Fahn, A. 1967. Plant anatomy. Pergamon. Fig. 97: leaf.

Pieters, A.H. 1901. The plants of western Lake Erie, with observations on their distribution. U.S. Fish Comm. Bull. for 1901.

\section{C. demersum}

Common and often an abundant weed. Shallow ponds and slow streams.

References: Arber, fig. 56: stem stele. Pieters, pl. 13: stem.

\section{C. echinatum}

Not common. Shallow water of pools and sluggish streams.

\section{CALTHA}

Map 153, Plate 47

One species in New York.

Korsmo, E. 1954. Anatomy of weeds. Grondahl \& Sons, Oslo, Norway.

\section{C. palustris}

Common and often abundant. Swamps, marshes, low meadows, ditches, and margins of streams.

Root 2-4 mm, becoming lacunate with age. Stem terete, slightly to strongly furrowed, $3-10+\mathrm{mm}$, bundles (about 20) widely separated in a ring, with well-developed xylem elements (vessels); between the xylem and the phloem is a distinct cambium in a curve with the concavity to the phloem; on the internal side of the xylem and on the external side of the phloem are crescent-shaped groups of fiber cells, in older stems these may meet; usually not confused with other genera, but see illustrations of Armoracia, Nasturtium, and Bidens. Petiole 2-3 mm. Peduncle semiterete, furrowed, 2-3 $\mathrm{mm}$, similar to stem.

Reference: Korsmo, fig. 74: root, stem, and petiole.

\section{RANUNCULUS}

Approximately 25 species in New York, of which six or seven grow in water. However, even with those species that grow mostly submersed, the stemlike parts are slightly (if at all) lacunate. Roots of some species (such as R. ficaria) may have a circle of lacunae and the petioles may have a lacuna on each side of the central bundle. Not illustrated.

Korsmo, E. 1954. Anatomy of weeds. Grondahl \& Sons, Oslo, Norway. Fig. 78: root, petiole, and stem.

Stover, E.L. 1951. An introduction to the anatomy of seed plants. Heath, Boston, Mass. Fig. 7: root. 
ARMORACIA

Map 154, Plate 48

One species in New York.

Metcalfe, C.R., and L. Chalk. 1950. Anatomy of the dicotyledons. Vol. 1. Clarendon Press, Oxford, England. Fig. 22: diagram of stem.

Stover, E.L. 1951. An introduction to the anatomy of seed plants. Heath, Boston, Mass. Fig. 94: stem (as Radicula).

\section{A. aquatica (Neobeckia a., Rorippa a.)}

Not common. Ponds and slow streams.

Root less than $1 \mathrm{~mm}$; cortex lacunate. Stem 2-6 mm; generally recognized by the combination of lacunate pith, solid bundle ring, and nonlacunate cortex (submersed stems of Rumex and Rorippa may have this combination of characters); emersed stem similar to submersed stem but lacunae smaller. Petiole of submersed leaves plano-convex, $\pm 1 \mathrm{~mm}$; emersed leaf petiole $\pm 1 \times 3 \mathrm{~mm}$. Peduncle 1 or $2 \mathrm{~mm}$, not lacunate except in age as tearing occurs in the pith.

\section{NASTURTIUM}

Map 155, Plate 49

Two species in New York.

\section{N. officinale (Sisymbrium nasturtium-aquaticum)}

Common. Ditches and shallow streams.

Stem 2-5 mm, mostly not lacunate but some cells of the pith and of the cortex may be very large, and there may be torn areas in the cortex. Petiole and peduncle seldom lacunate. Anatomical patterns of Cardamine may be similar to those of Nasturtium.

\section{N. microphyllum (N. officinale var. $\mathrm{m}$ )}

Rare or overlooked, Rockland, Delaware, and Suffolk Counties.

Stem 2-3 mm. Not examined.

\section{RORIPPA}

Map 156

Four species in New York. One is commonly found in wet places and occasionally in shallow water. Not illustrated.

Korsmo, E. 1954. Anatomy of weeds. Grondahl \& Sons, Oslo, Norway. Fig. 94, pl. 46.

R. palustris (R. islandica, Radicula p., Radicula hispida) Stem subterete, often furrowed, 1-10 mm; pattern similar to Arinoracia.

\section{SUBULARIA}

Map 157

One species in New York. Not illustrated.

\section{S. aquatica}

Local. Shallow water.

Stem more or less lacunate, but only $\pm 0.5 \mathrm{~mm}$. Leaf less than $1 \mathrm{~mm}$, with a conspicuous ceritral bundle and a strongly lacunate cortex; similar to the simple pattern of several other tiny stems. See statement under Callitriche.

\section{CALLITRICHE}

Maps 158-162

Six species in New York, of which five are found in water.

Stems less than $1 \mathrm{~mm}$; stele simple, being a small ring of xylem surrounded by phloem; there is no cambium; the tiny pith soon becomes hollow; endodermis evident (apparently absent in the root); cortex with a single circle of lacunae separated by 1-cell-wide chains of cells. Stem pattern simple and similar to several other tiny stems: Potamogeton, Ruppia, Zannichellia, Najas, Elodea, and Elatine. Not illustrated.

Arber, A. 1920. Water plants. Cambridge University Press. Sculthorpe, C.D. 1967. The biology of aquatic vascular plants. St. Martin.

C. anceps (C. heterophylla in part)

Colton Flow, Raquette R., St. Lawrence County. Not examined.

C. hermaphroditica (C. autumnalis)

Occasional. Quiet water.

\section{C. heterophylla}

Occasional to common. Quiet shallow water.

\section{C. stagnalis}

Rare to locally frequent in quiet or flowing water.

References: ARBER, figs. 114, 138: stem and root steles. Sculthorpe, fig. 6.10: root stele.

C. terrestris (C. deflexa)

Rare. Damp soil. Not examined.

C. verna (C. palustris)

Common. Pools, springs, and lake shores.

\section{HYPERICUM}

Map 163, Plate 50

Several species in New York, of which three or four grow in wet places. The roots, and sometimes also the young stems, may be lacunate. Only one species (found growing in shallow water) examined. 


\section{H. ellipticum}

Common. Swamps, marshes, and shores of ponds and streams.

Rhizome 1-2 mm, more or less lacunate; stem and peduncle not lacunate.

\section{TRIADENUM}

Map 164, Plate 50

One or two species in New York; treated here as one.

T. virginicum ( $\mathrm{T}$. fraseri, Hypericum v.)

Common. Marshes and swamps. Rhizome terete, 1-3 mm. Stem above water and peduncle not lacunate.

ELATINE Maps 165-166

Two species in New York. Not illustrated.

Eames, A.J., and L.H. MacDaniels. 1967. An introduction to plant anatomy. 2d ed. McGraw-Hill. Fig. 183: stem stele.

E. americana (E. triandra)

Occasional. Shallow water of ponds and slow streams. Not examined.

\section{E. minima}

Rare to locally frequent. Shallow water of ponds and slow streams.

Stem terete, $\pm 1 \mathrm{~mm}$, with a small central stele; pith absent; endodermis evident; cortex with a circle of large lacunae, separated by 1-cell-wide chains of cells. Stem pattern simple and similar to several other tiny stems: Potamogeton, Ruppia, Zannichellia, Najas, Elodea, Callitriche, and Utricularia.

\section{LUDWIGIA}

Map 167, Plate 51

Four species in New York, but only one is commonly found submersed.

\section{L. palustris}

Common. Shallow water of ponds, streams, and marshes. Often completely submersed or forming floating mats.

Stem 1-2 mm. Rhizome, stem, and petiole patterns similar; with a single central bundle. Petiole sometimes with 1 or 2 accessory bundle strands. Somewhat similar to rhizome of Triadenum and stem of Hippuris.
TRAPA

Map 168, Plates 52-53

One species in New York.

\section{T. natans}

Not native but locally abundant and weedy. Quiet water of rivers and lakes.

Root less than $1 \mathrm{~mm}$ with a single central bundle. Stem 2-4 mm, anatomical pattern similar for submersed and emersed parts. Petiole 1-3 $\mathrm{mm}$ (below floater) to $5 \mathrm{~mm}$ (above floater) to $10 \mathrm{~mm}$ (floater), lacunate but variable in amount. Peduncle $2-10 \mathrm{~mm}$, smallest near the lower portion (illustrated), largest in the upper portion and with larger lacunae in the cortex. The stem is not easily confused with other genera, but the peduncle is somewhat similar to the stems of Lysimachia and Menyanthes.

MYRIOPHYLLUM Maps 169-176, Plates 54-55

Nine species in New York.

Rhizomes, stems, and peduncle terete, 1-3 mm. Patterns essentially the same; with a nonlacunate stele, with or without a pith area (considered to be not a true pith but undeveloped xylem); with a large cortex having an evident endodermis and a single circle of large lacunae separated by 1-cell-wide chains of cells, strongly appearing as spokes in a wheel. This pattern is also seen in Marsilea, Gratiola, and Utricularia. Perhaps also in the rare Hottonia. Also some other genera whose stems are usually less than $1 \mathrm{~mm}$. Spherical, spiny, asteriskshaped cluster crystals, $0.02-0.03 \mathrm{~mm}$ are frequently seen in freehand sections but only occasionally seen in the microtome-cut, chemically treated tissues in our permanent slide collection. Leaves less than $1 \mathrm{~mm}$, often with radially arranged lacunae. This pattern is also found in leaves of Ceratophyllum, Utricularia, and Littorella. Peduncles absent or similar to stem.

Arber, A. 1920. Water plants. Cambridge University Press.

Burström, H.G., and C. Odhnoff. 1963. Vegetative anatomy of plants. Svenska Bokförlaget, Stockholm, Sweden. Fig. 78: stem.

Molisch, H. 1954. Anatomie der Pflanze. Gustav Fischer, Jena, E. Germany.

\section{M. alterniflorum}

Rare. Shallow water. Stem 1-2 mm.

\section{M. brasiliense}

Not native but introduced on Long Island into streams and ponds.

Stem 2-3 $\mathrm{mm}$. Central large area appears to be true pith. 
Reference: MoLISCH, fig. 98: stem (as $M$. proserpinacoides).

\section{M. farwellii}

Rare. Shallow acid water. Stem $\pm 1 \mathrm{~mm}$.

\section{M. heterophyllum}

Rare to local. Ponds and slow streams. Stem 1-6 mm.

\section{M. humile}

Locally common. Shallow water and muddy banks. Stem $\pm 1 \mathrm{~mm}$.

M. pinnatum (M. scabratum)

Rare. Long Island and Orange County. Shallow acid water. Stem $\pm 1 \mathrm{~mm}$. Not examined.

\section{M. spicatum (M. exalbescens)}

Common and often an abundant weed. Our native plant is $M$. spicatum ssp. exalbescens, but apparently the Eurasion ssp. spicatum is established and increasing in the State. Both subspecies may be troublesome weeds. Shallow or deep, calcareous or brackish water of ponds and quiet streams. Stem 2-3 mm.

Reference: ARBER, fig. 109: leaf; figs. 116, 117: stem.

\section{M. tenellum}

Occasional. Sandy ponds and slow streams. Stem $1-2 \mathrm{~mm}$.

\section{M. verticillatum}

Frequent. Deep or shallow lakes and streams, often in flowing water. Stem $1-3 \mathrm{~mm}$.

\section{PROSERPINACA}

Map 177, Plate 56

Two species in New York.

Stover, E.L. 1951. An introduction to the anatomy of seed plants. Heath, Boston, Mass.

\section{P. palustris}

Occasional. Temporary pools and shallow margins of ponds.

Stem angular-terete, 1-2 mm. Amount of lacunation varies from submersed to emersed parts. Pattern similar to Hippuris but stele much larger in proportion and cortex with 1 or 2 circles of lacunae; also somewhat like stem of Ludwigia; cluster crystals occur. Submersed leaf oblong to terete, less than $1 \mathrm{~mm}$, with large cells but not lacunate.

Reference: Stover, fig. 65: leaf.

\section{P. pectinata}

Rare. Pond and stream margins. Suffolk and Orange Counties. Stem $\pm 1 \mathrm{~mm}$, similar to $P$. palustris. Leaf not examined.

\section{HIPPURIS}

Map 178, Plate 56

One species in New York.

Lloyd, B. 1949. Handbook of botanical diagrams. 2d ed. University of London Press, London, England. Pl. 34: stem.

Sculthorpe, C.D. 1967. The biology of aquatic vascular plants. St. Martin.

Tron, E. Zh. 1967. Anatomical structure of the stem of Hippuris vulgaris L. [in Russian, English summary]. Bot. Zh. 52:811-819. No illustration.

\section{H. vulgaris}

Rare. Shallow water of ditches and marshy ponds. Submersed stem, 1-2 mm; cortex strongly lacunate; stele similar to that of Myriophyllum but usually with more strongly developed xylem; there is no true pith but the central parenchyma cells may appear pithlike in young stems; cortex with more than 1 circle of lacunae; endodermis clearly evident. Similar to stems of Elodea, Proserpinaca and Ludwigia.

Reference: SCUlthorPE, figs. 5.16, 5.26: stem.

\section{HYDROCOTYLE}

Map 179, Plate 57

Three species in New York. One with lacunate parts.

\section{H. umbellata}

Not common. Wet ground and shallow water.

Stem (rhizome) terete, 1-2 mm. Petiole 1-2 mm. Peduncle not examined. The stem is similar to some species of Potamogeton, especially $P$. perfoliatus and $P$. richardsonii, but without an inner patch of phloem on any bundle; also similar to $P$. alpinus and $P$. nodosus which have no pseudohypodermis; the stele is similar to that found in some collections of $P$. illinoensis, which species is easily separated by the cortical bundles; Potamogeton usually has a more evident endodermis.

\section{LYSIMACHIA}

Maps 180-181, Plate 58

Several species in New York, of which two may grow in water.

Rhizomes and stems similar, terete, 1-7 mm, lacunate in pith and cortex; secretory cells and cavities present in pith and cortex. Patterns somewhat similar to Triadenum, Menyanthes, Rhynchospora, and Sparganium. Peduncles terete or squarish, $\pm 1 \mathrm{~mm}$, similar to stem but less lacunate. 


\section{L. nummularia}

Common. Wet places and occasionally in water. Stem 1-2 mm, pattern similar to L. terrestris.

\section{L. terrestris}

Common. Low ground and swamps. Stem 1-7 mm.

\section{MENYANTHES}

Map 182, Plate 59

One species in New York.

Metcalfe, C.R., and L. Chalk. 1950. Anatomy of the dicotyledons. Vol. 2. Clarendon Press; Oxford, England.

\section{M. trifoliata}

Rare to locally frequent. Wet bogs and margins of bog streams.

Root $\pm 1 \mathrm{~mm}$, slightly to highly lacunate. Stem and rhizome similar, 2-8 $\mathrm{mm}$; cortex usually with (but sometimes without) bundles; specimens without bundles in the cortex are somewhat similar to stem of Lysimachia and peduncle of Trapa. Petiole 2-3 mm, usually with 5 or 6 large bundles and 1 or more small ones in a circle. Peduncle similar to petiole.

Reference: Metcalfe and Chalk, fig. 216: petiole.

\section{NYMPHOIDES}

Maps 183-184, Plate 60

Two species in New York.

Stems from less than 1 to $3 \mathrm{~mm}$; cortex with 1 to several circles of lacunae; branched idioblasts usually common. Petioles less than 1 to $2 \mathrm{~mm}$, terete or plano-convex; idioblasts common. The idioblasts distinguish this genus from all except Nuphar and Nymphaea, whose patterns are much different.

Metcalfe, C.R., and L. Chalk. 1950. Anatomy of the dicotyledons. Vol. 2. Clarendon Press, Oxford, England.

\section{N. cordatum (Trachysperma lacunosa)}

Occasional to locally common. Open water of lakes. Stem mostly less than $1 \mathrm{~mm}$. Floaters $2 \mathrm{~mm}$, not lacunate. Petiole less than $1 \mathrm{~mm}$.

\section{N. peltatum}

Not native but introduced and locally abundant in the Hudson River. Stem $\pm 3 \mathrm{~mm}$. Floaters absent. Petiole 2-3 mm. Peduncle less than $1 \mathrm{~mm}$.

Reference: Metcalfe and ChalK, fig. 216: petiole (as Limnanthemum peltatum).

\section{GRATIOLA}

Maps 185-186, Plate 61

Two species in New York.

Roots usually less than $1 \mathrm{~mm}$. Stems and rhizomes similar, 1-3 mm; pith small or large, becoming hollow; xylem forming a solid circle; cortical lacunae large, mostly in a single circle. The pattern is superficially similar to Myriophyllum, Utricularia, and Marsilea; also some other genera whose stems are usually less than 1 $\mathrm{mm}$. Peduncle similar to stem, but usually less than 1 $\mathrm{mm}$.

G. aurea (G. lutea)

Occasional or locally common. Wet sandy or peaty soil and shallow water.

\section{G. neglecta}

Common. Wet soil.

\section{LINDERNIA}

Maps 187-188, Plate 62

Three species in New York, of which two are common.

Stems 1-3 mm; square with 4 small cortical (subepidermal) bundles at the 4 corners. Pith solid, terete, surrounded by a circle of bundles, separate or essentially so. Cortex highly lacunate with large lacunae; these lacunae extending from the stelar bundles nearly to the epidermis.

L. anagallidea (Ilysanthes inaequalis)

Infrequent to locally common. Wet soil.

L. dubia (Ilysanthes d.)

Frequent to locally common. Wet soil or shallow water.

\section{L. pyxidaria}

Rare. Jefferson County. Wet soil.

\section{MIMULUS} Maps 189-192, Plate 63

Four species in New York.

Stems scarcely 50 percent lacunate; only one species examined in detail.

\section{M. alatus}

Occasional. Marshes and swamps.

M. guttatus (M. langsdorfii)

Rare. Low ground. 


\section{M. moschatus}

Occasional. Wet places.

\section{M. ringens}

Common. Marshes, edges of streams and swamps, wet meadows.

Stem subterete at base, $3-8 \mathrm{~mm}$, becoming squarish above and smaller to less than $1 \mathrm{~mm}$; pith of roundish cells, soon becoming hollow; bundle area a solid ring; pericycle with groups of fiber cells; cortex lacunate with 1-cell chains of cells, the lacunae extending to the epidermis.

\section{UTRICULARIA}

Maps 193-205, Plate 64

Thirteen species in New York.

Stems terete, mostly less than $1 \mathrm{~mm}$, sometimes to 2 $\mathrm{mm}$; stele of 1 or more tracheids surrounded by little groups of phloem; endodermis of thin-walled cells similar to the cells of the cortex and appearing merely as a circle of cortical cells around the thicker walled cells of the stele; cortex of submersed and emersed stems differ in amount of lacunation. Stem pattern simple and similar to several other tiny stems: Marsilea, Potamogeton, Ruppia, Zannichellia, Najas, Elodea, Elatine, Callitriche. Leaves with a single simple bundle; mesophyll with large lacunae reaching the epidermis. Peduncles terete, from less than 1 to $3 \mathrm{~mm}$; patterns different from stems; xylem in a ring, discontinuous or continuous; pith solid to partly hollow; cortex lacunate (except $U$. cornuta).

Arber, A. 1920. Water plants. Cambridge University Press.

U. biflora (U. pumila)

Rare. Suffolk County. Shallow water. Not examined.

\section{U. cornuta}

Occasional to locally 'common. Bogs and sandy shores. Stem less than $1 \mathrm{~mm}$. Not examined. Peduncle (scape) not lacunate.

\section{U. fibrosa}

Rare to locally frequent. Suffolk County. Shallow water. Not examined.

U. geminiscapa ( $U$. clandestina)

Rare. Shallow water. Not examined.

\section{U. gibba}

Rare. Shallow water. Stem less than $1 \mathrm{~mm}$. Peduncle less than $1 \mathrm{~mm}$; xylem in a continuous ring; pith solid.

\section{U. inflata ( $U$. radiata)}

Rare. Quiet water. Stem less than $1 \mathrm{~mm}$; peduncle $\pm 1 \mathrm{~mm}$; pattern similar above and below floaters; pith solid to hollow.

\section{U. intermedia}

Occasional to locally common. Shallow water. Stem $\pm 1 \mathrm{~mm}$. Peduncle less than $1 \mathrm{~mm}$; bundles separate in a ring.

U. juncea ( $U$. virgatula)

Rare. Sandy shores. Not examined.

\section{U. minor}

Rare or occasional. Shallow water. Not examined. Reference: ARBER, fig. 74: leaf.

\section{U. purpurea}

Occasional to frequent. Quiet water. Stem $\pm 1 \mathrm{~mm}$. Peduncle with solid pith containing a few small bundles; cortex with a circle of large lacunae, separated by 1-cellwide chains of cells, similar to stem of Myriophyllum.

\section{U. resupinata}

Frequent to common. Shallow water. Stem less than $1 \mathrm{~mm}$. Not examined.

\section{U. subulata}

Rare. Wet sandy soil. Not examined.

\section{U. vulgaris (U. macrorhiza)}

Common and often abundant. Slow streams and quiet water (often stagnant) of lakes. Stem 1-2 mm. Peduncle 1-3 mm.

\section{JUSTICIA}

Map 206, Plate 65

One species in New York.

Metcalfe, C.R., and L. Chalk. 1950. Anatomy of the dicotyledons. Vol. 2. Clarendon Press, Oxford, England.

Jones, W.R. 1912. The development of the vascular structure of Dianthera americana. Bot. Gaz. 54:1-30.

\section{J. americana (Dianthera a.)}

Locally common. Shallow water of lakes and streams. Root $\pm 2 \mathrm{~mm}$. Rhizome terete, $3-5 \mathrm{~mm}$. Stem angularterete, 2-3 mm, similar to rhizome but less lacunate; there are 6 bundles (steles) in a circle and a 7 th in the center; each has an endodermis; not easily confused with any other genus. Peduncle 1-2 mm, not lacunate; bundle tissue in a continuous ring. 


\section{LOBELIA}

Map 207, Plate 66

Seven species in New York, of which one is commonly found in water.

Armand, M.L. 1912. Recherches morphologiques sur le Lobelia dortmanna L. Rev. gén de Botanique 24:465-478.

\section{L. dortmanna}

Common. Shallow ponds. Root less than $1 \mathrm{~mm}$. Leaf $\pm 1.5 \times 2.5 \mathrm{~mm}$, with 2 large lacunae as in Ruppia. Peduncle (scape) terete, $2-3 \mathrm{~mm}$, scarcely lacunate, with a large hollow pith.

Reference: ARMAND, figs. 4, 11: root and peduncle.

\section{BIDENS}

Map 208, Plate 67

Sixteen species in New York, of which one is sufficiently lacunate to be included here.

Pieters, A.J. 1901. The plants of western Lake Erie, with observations on their distribution. U.S. Fish Comm. Bull. for 1901.

\section{B. beckii (Megalodonta b.)}

Occasional. Lakes and slow streams.

Stem 1-4 mm. Stem between roots with small stele, solid pith, and cortex with large lacunae. Stem between emersed leaves with many bundles in a well-defined ring, pith hollow, and cortex with small lacunae. Middle of stem intermediate, mostly with large solid pith, bundles in a ring, and cortex with large lacunae. In older stems, the area between bundles is filled with fiber cells. Because of variability due to age and position of parts in relation to water, the pith may be solid or hollow, the bundles separate or continuous, and the cortex may be slightly to strongly lacunate. Thus the stem may be similar to several other genera. Peduncle 1-2 mm, similar to stem above water.

Some of the other species of Bidens may have a highly lacunate cortex at base, but this area is only a small portion of the stem area.

Reference: Pieters 1901, pl. 13: stem. 


\section{Distribution Maps}




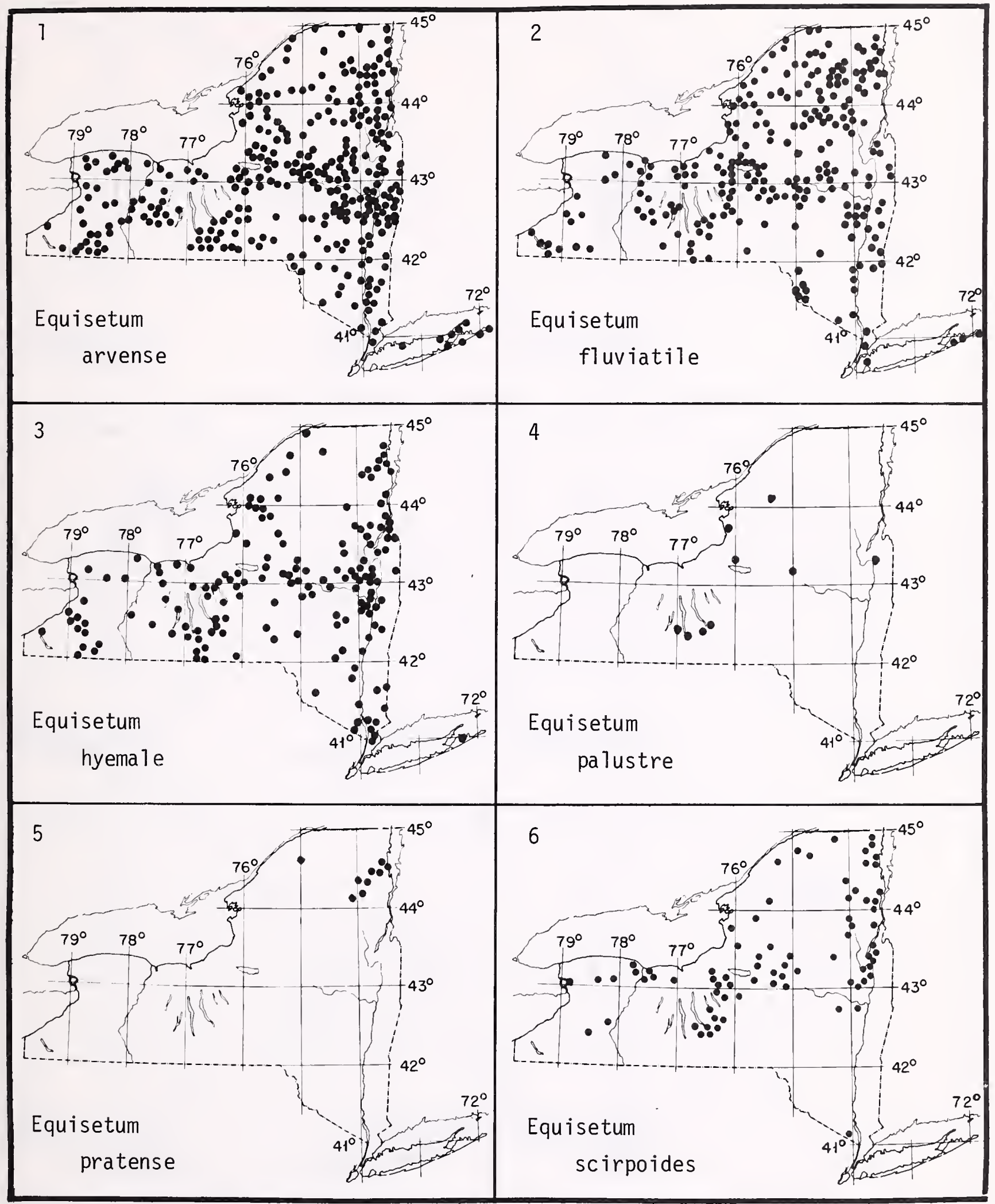




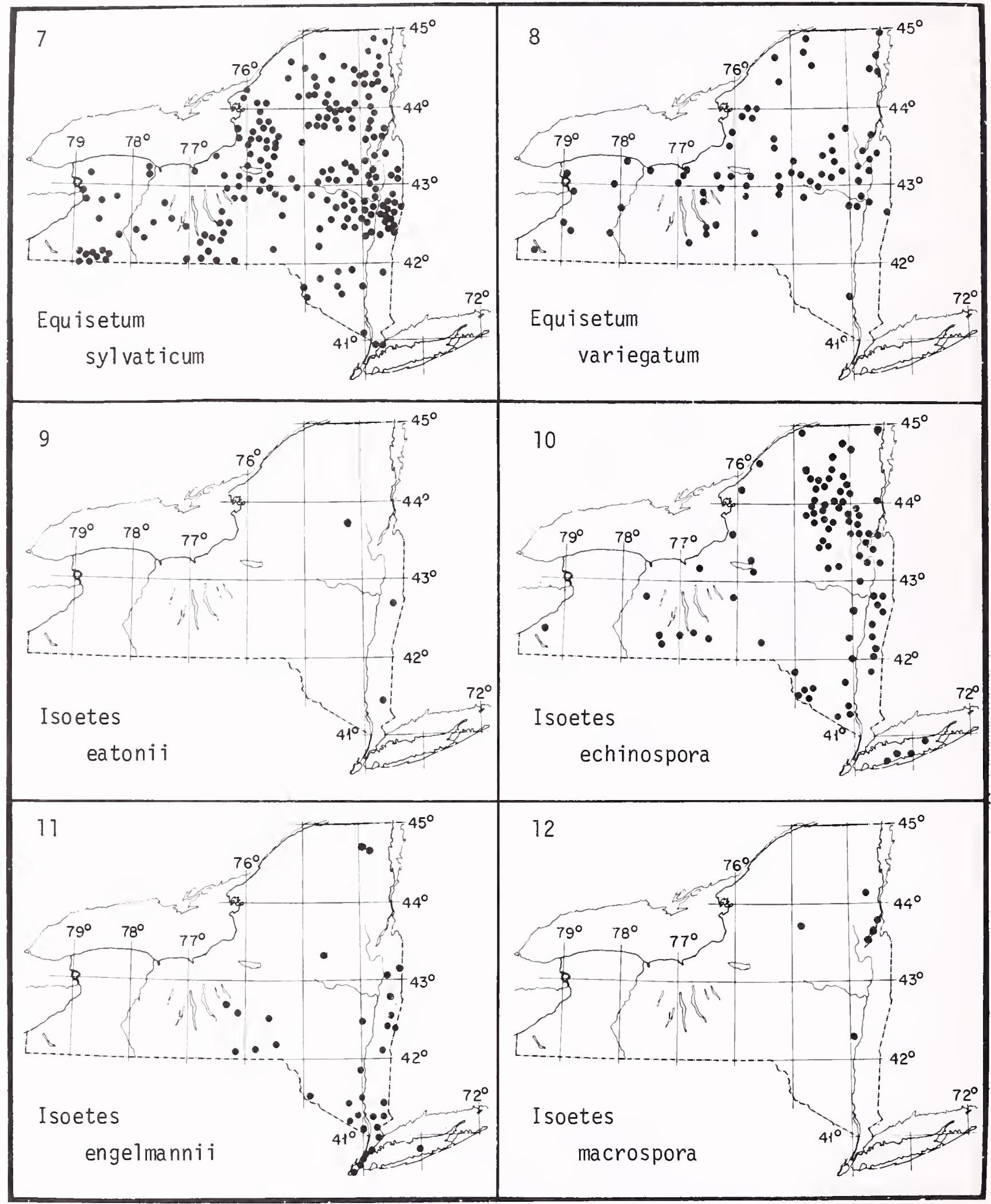




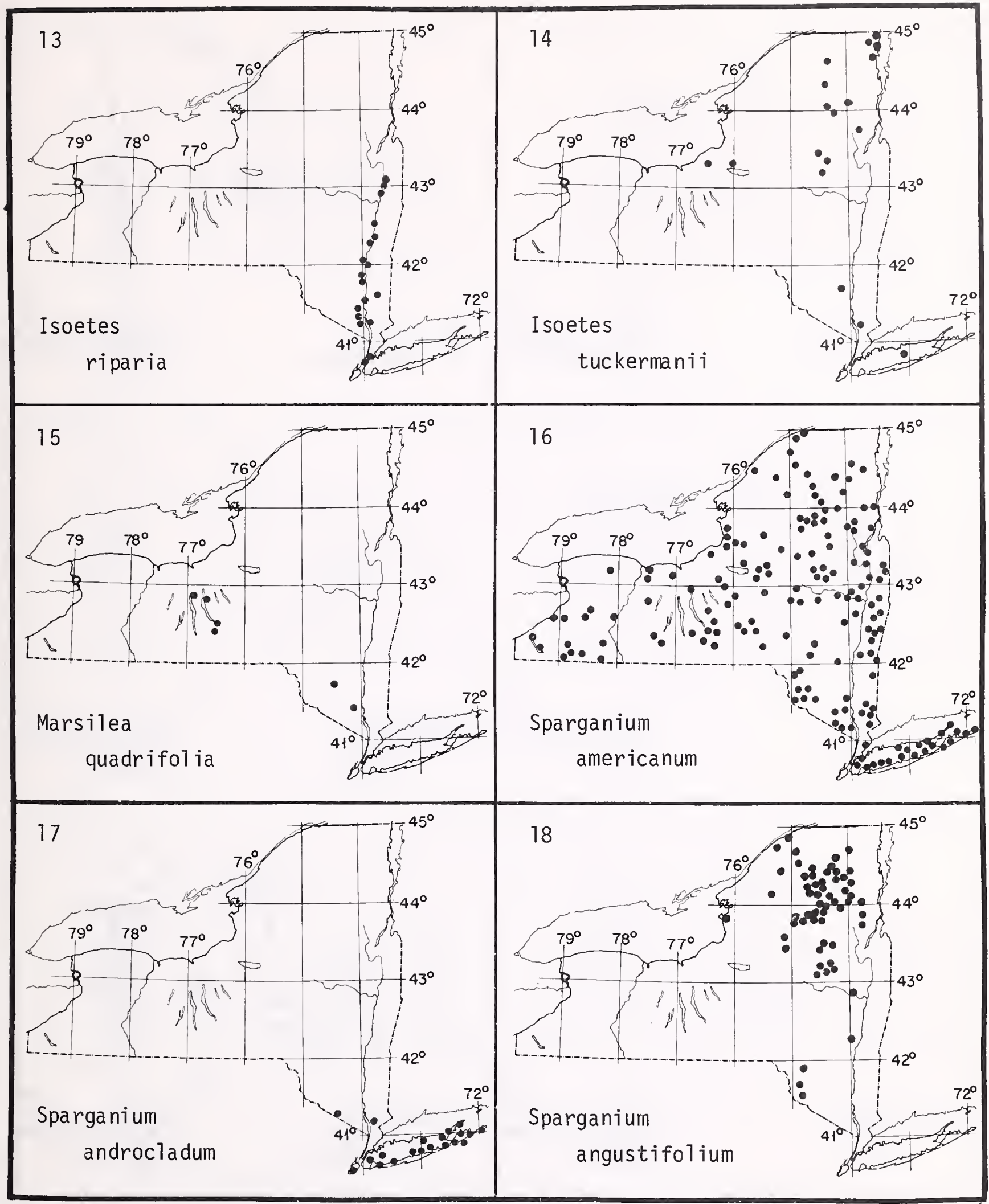




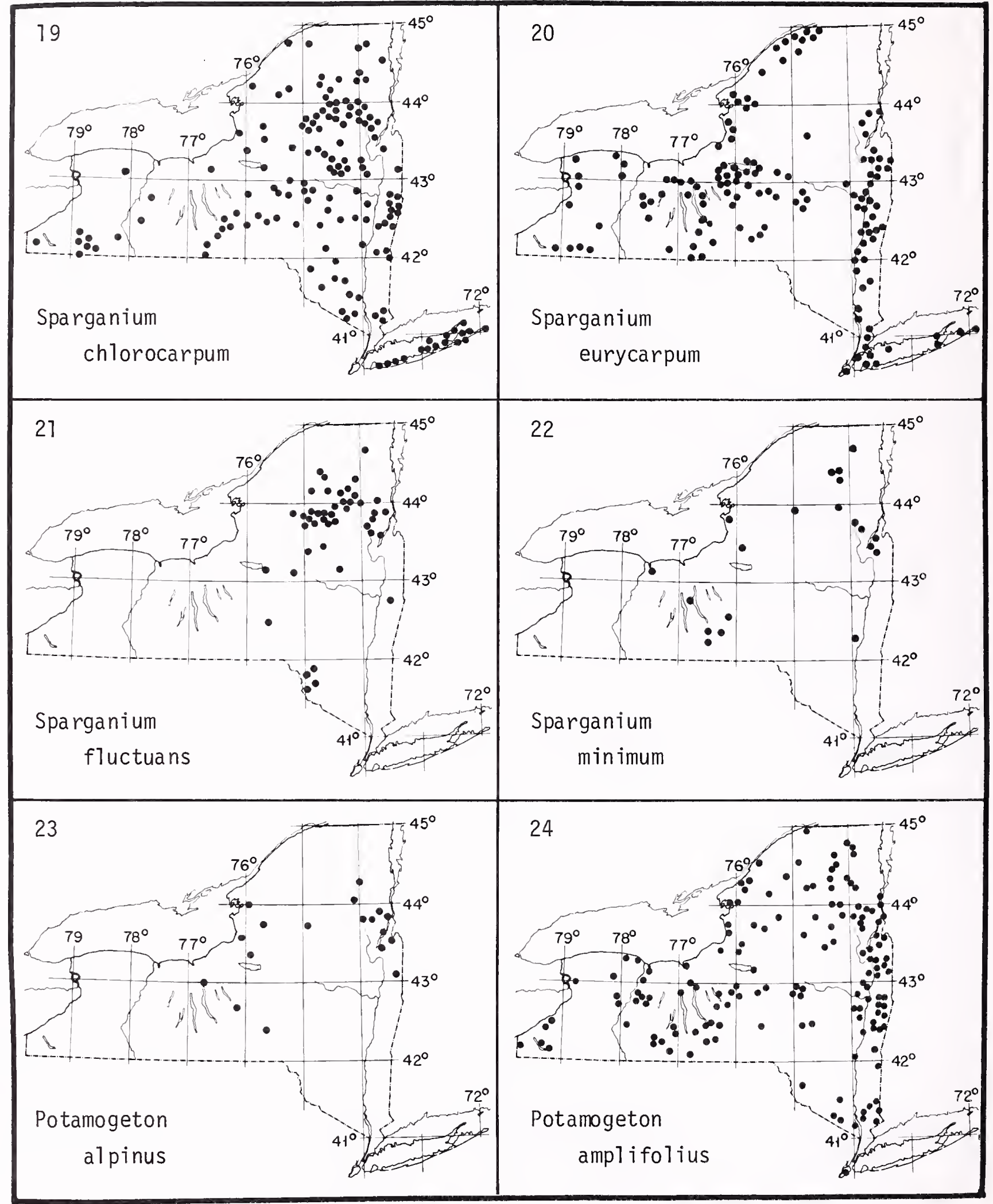




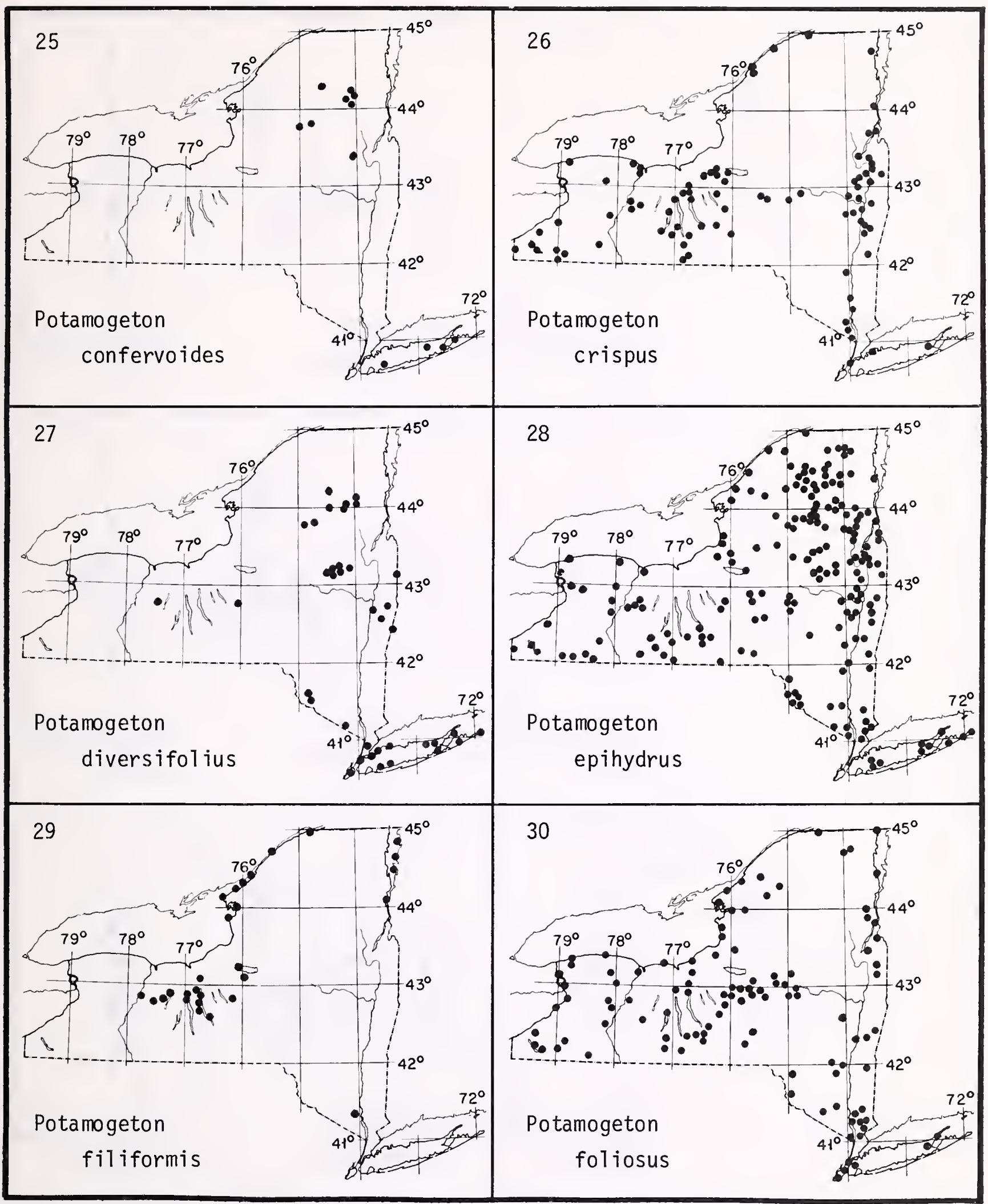




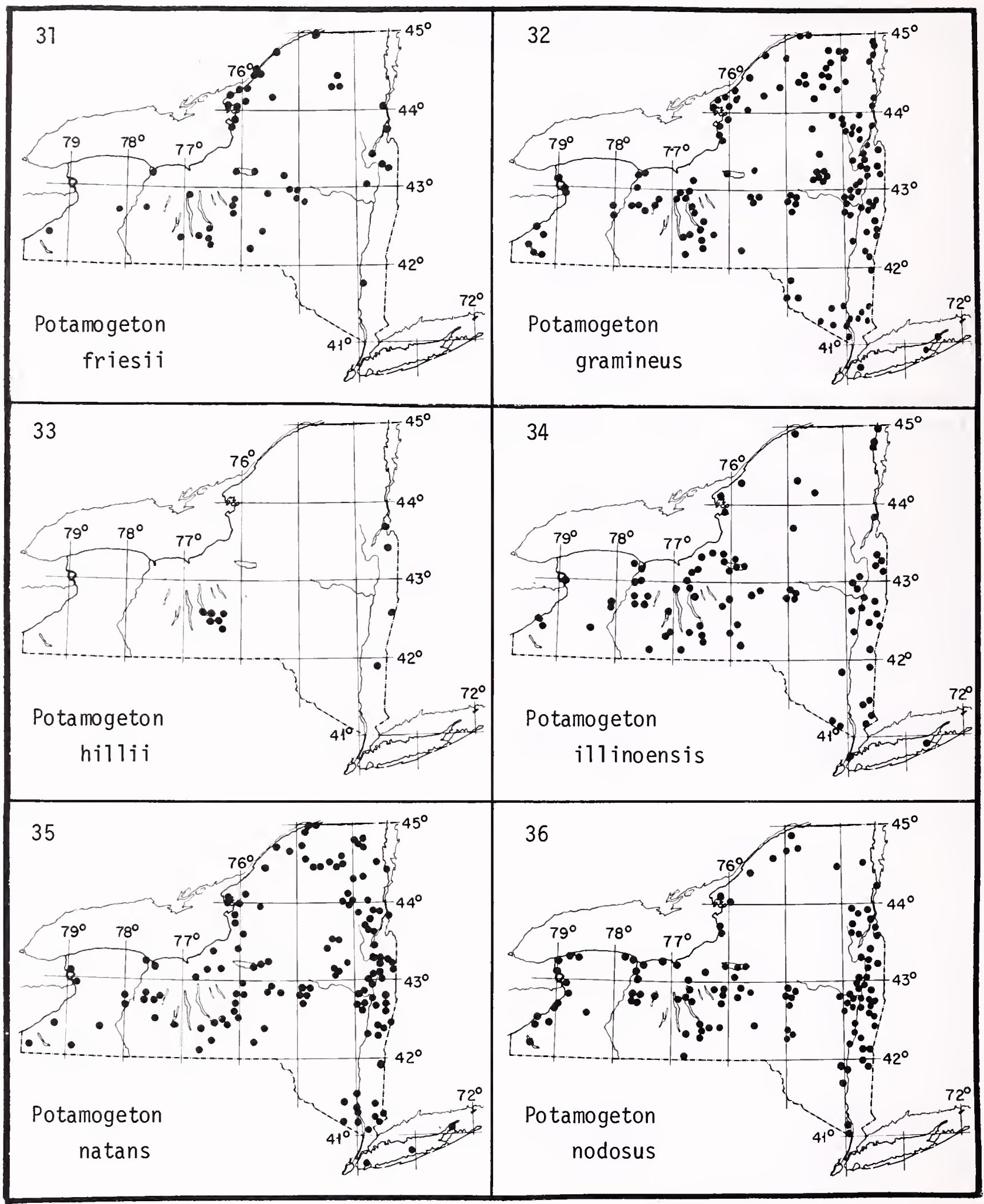




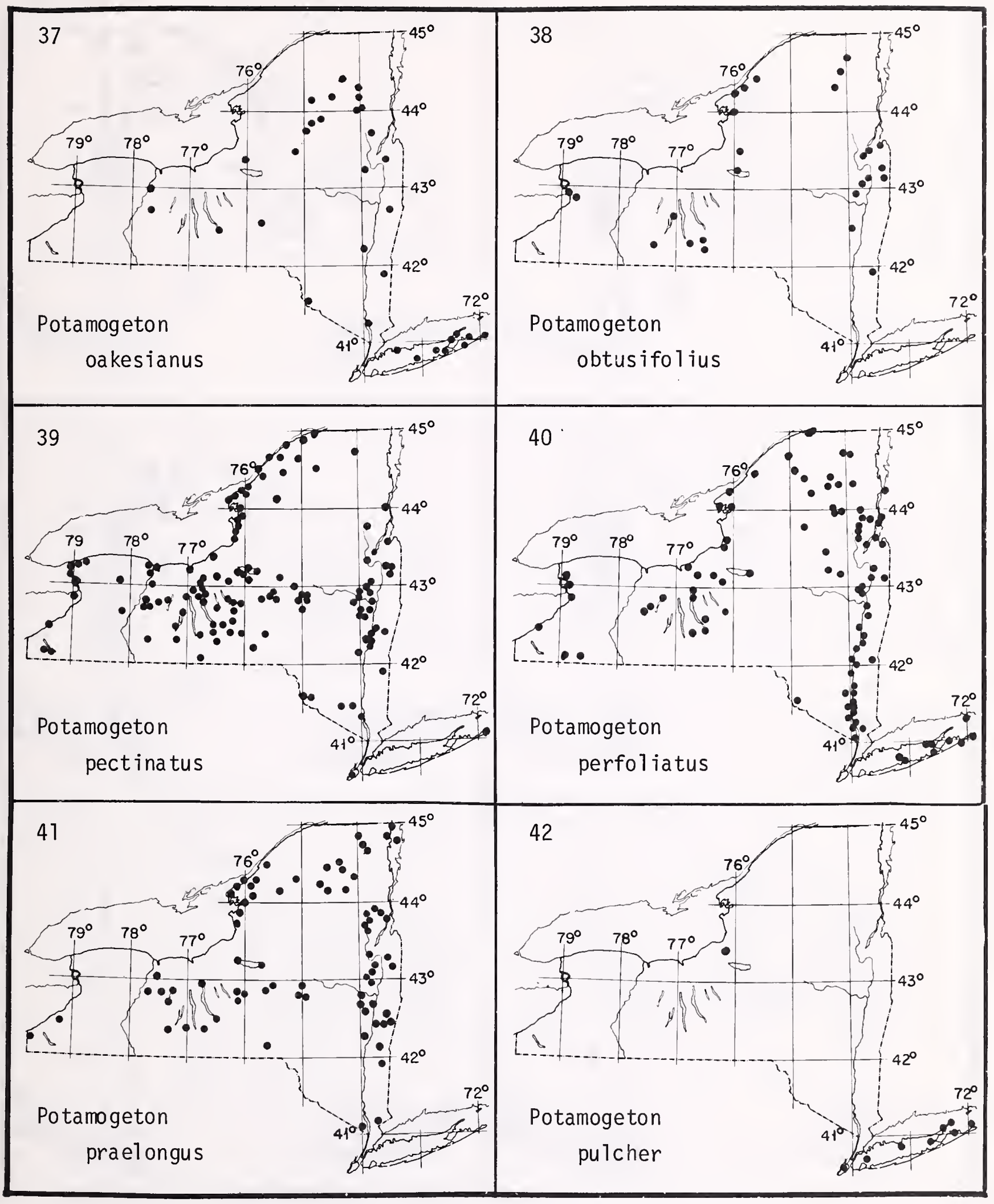




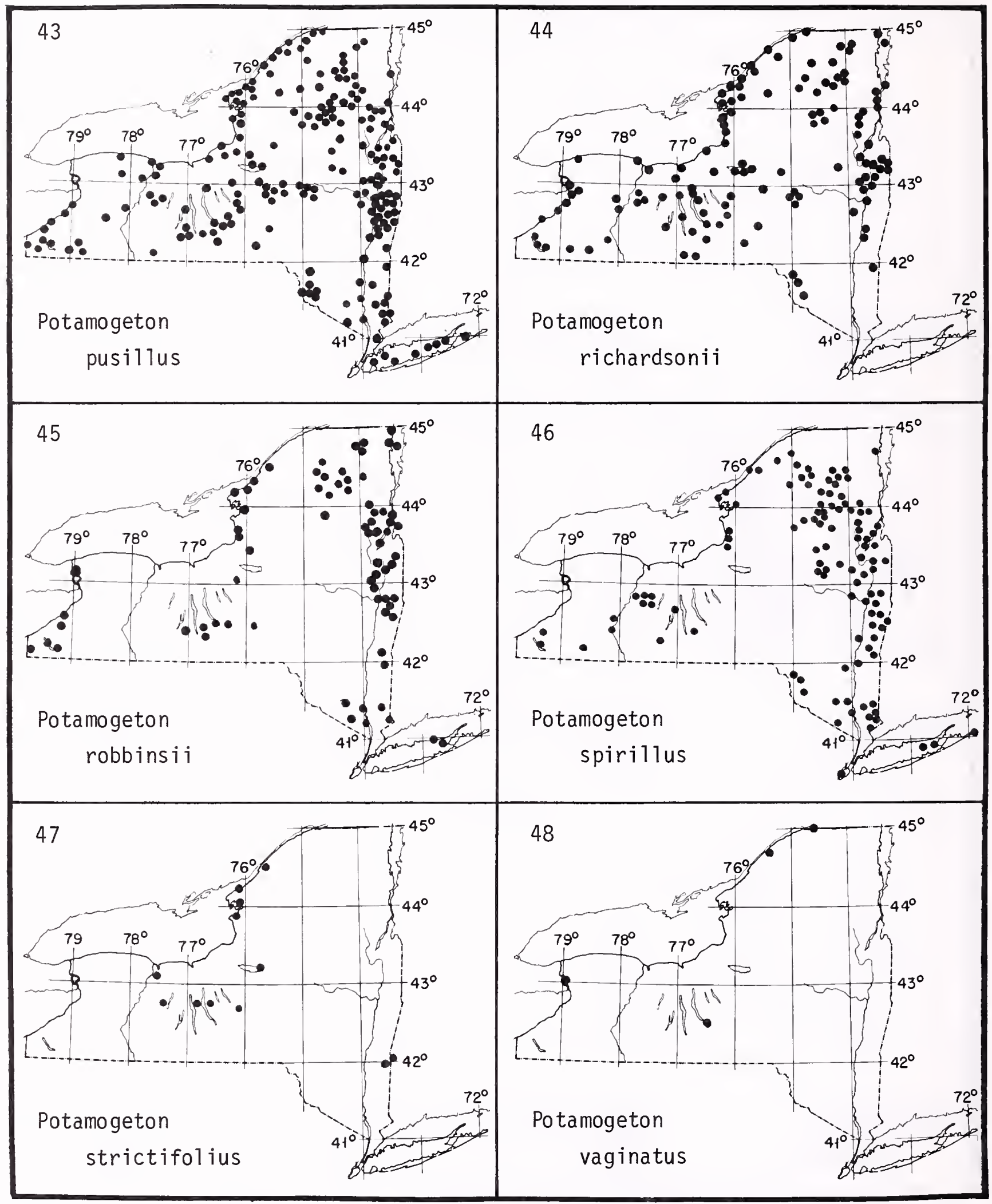




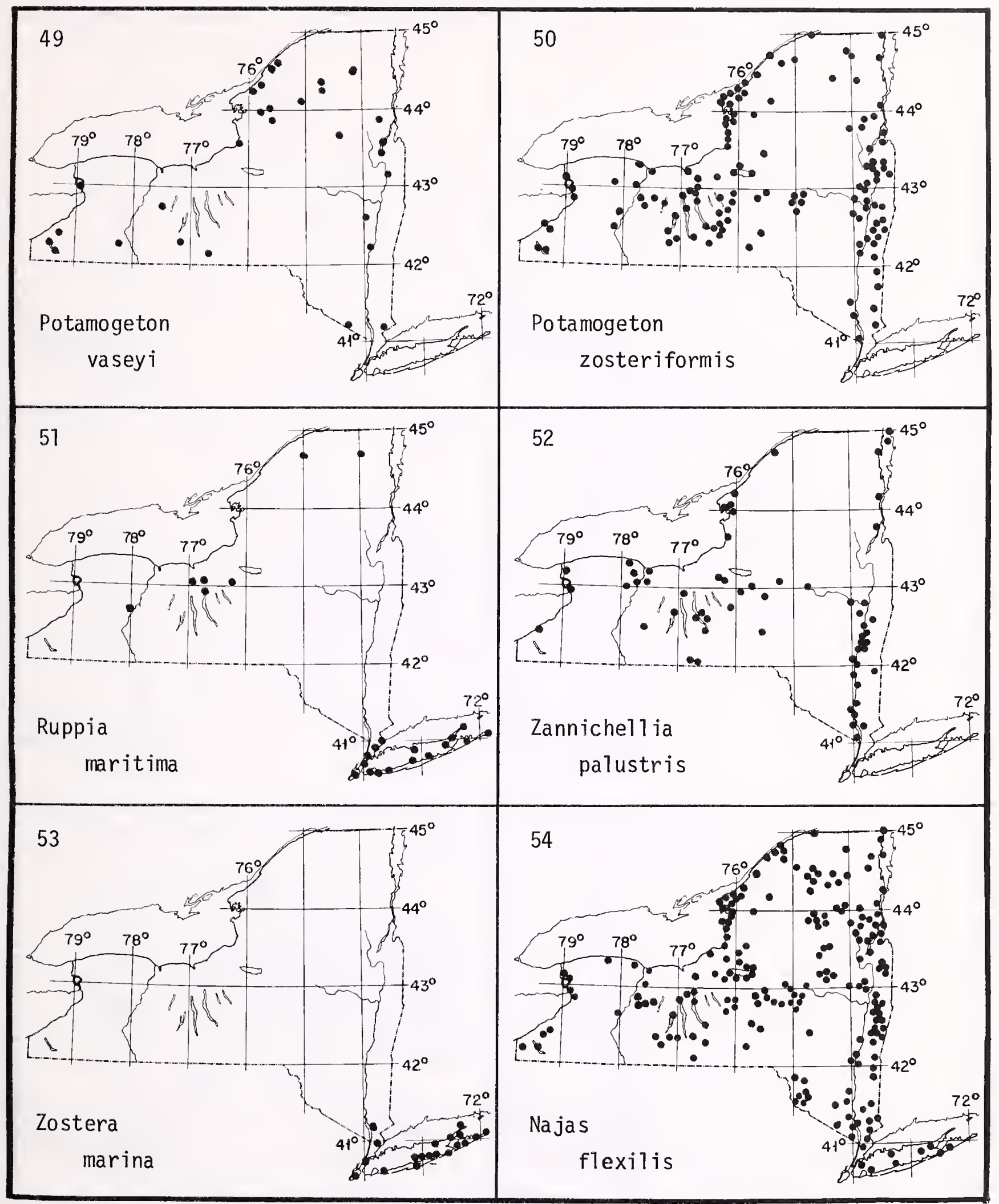




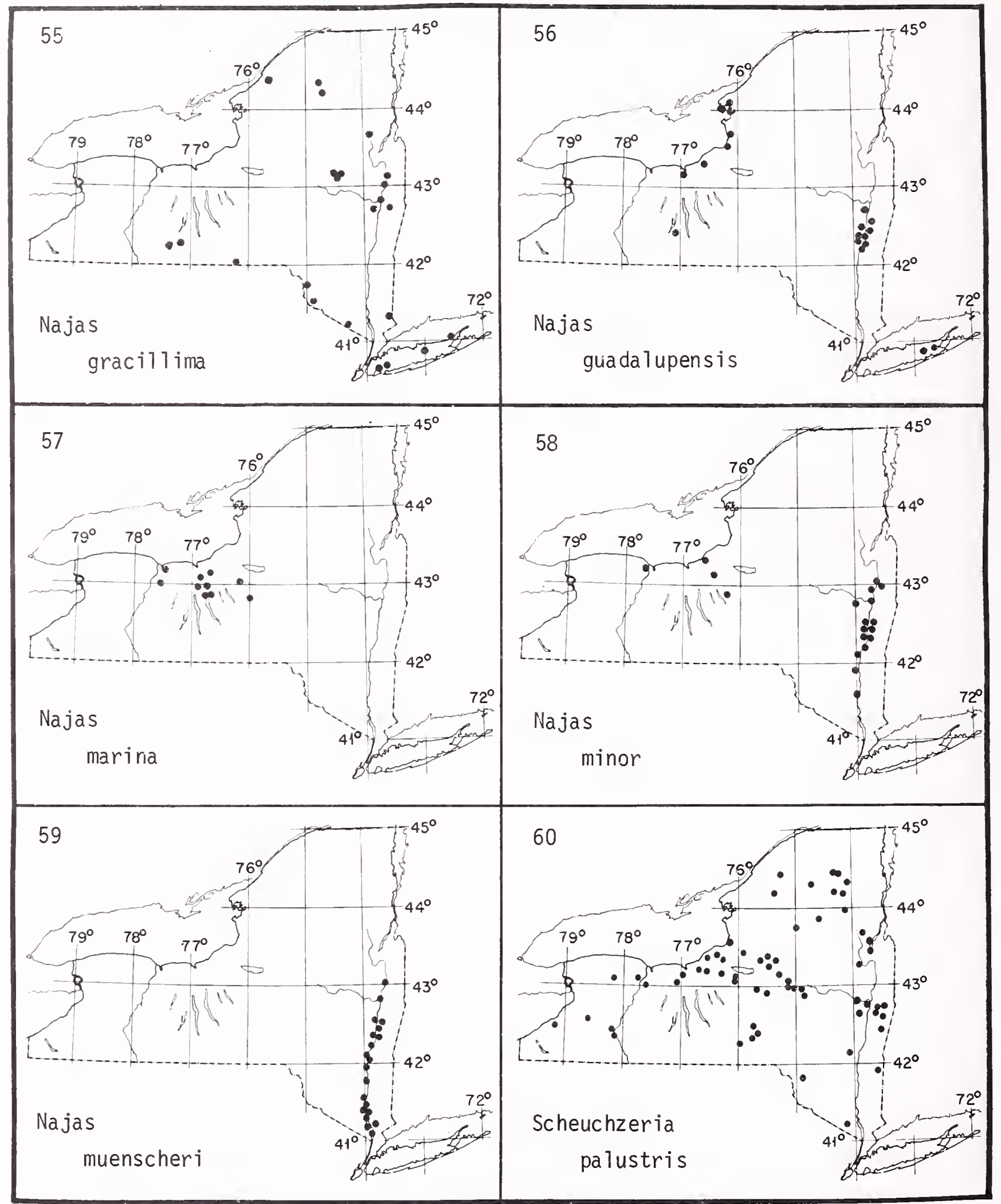




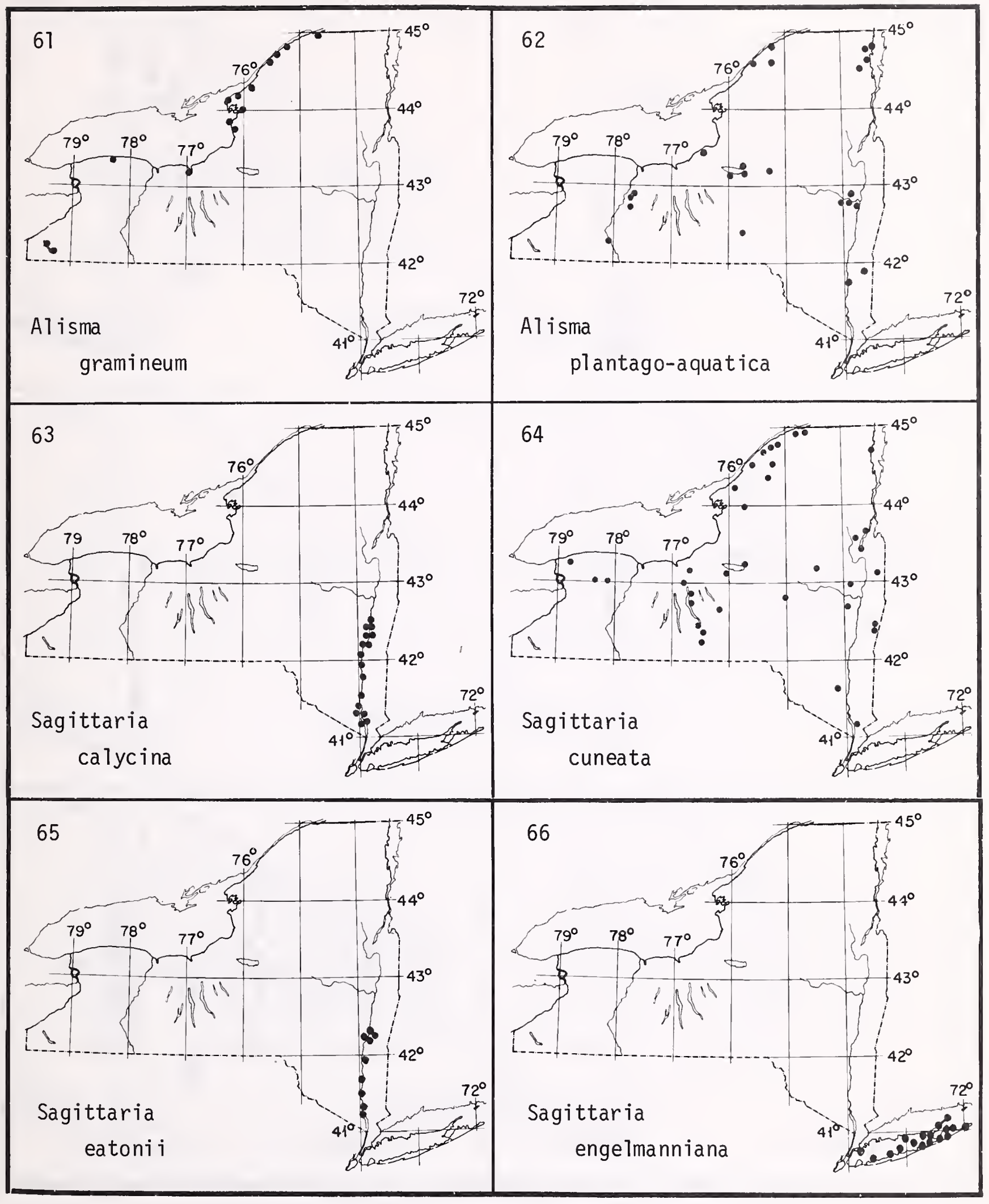




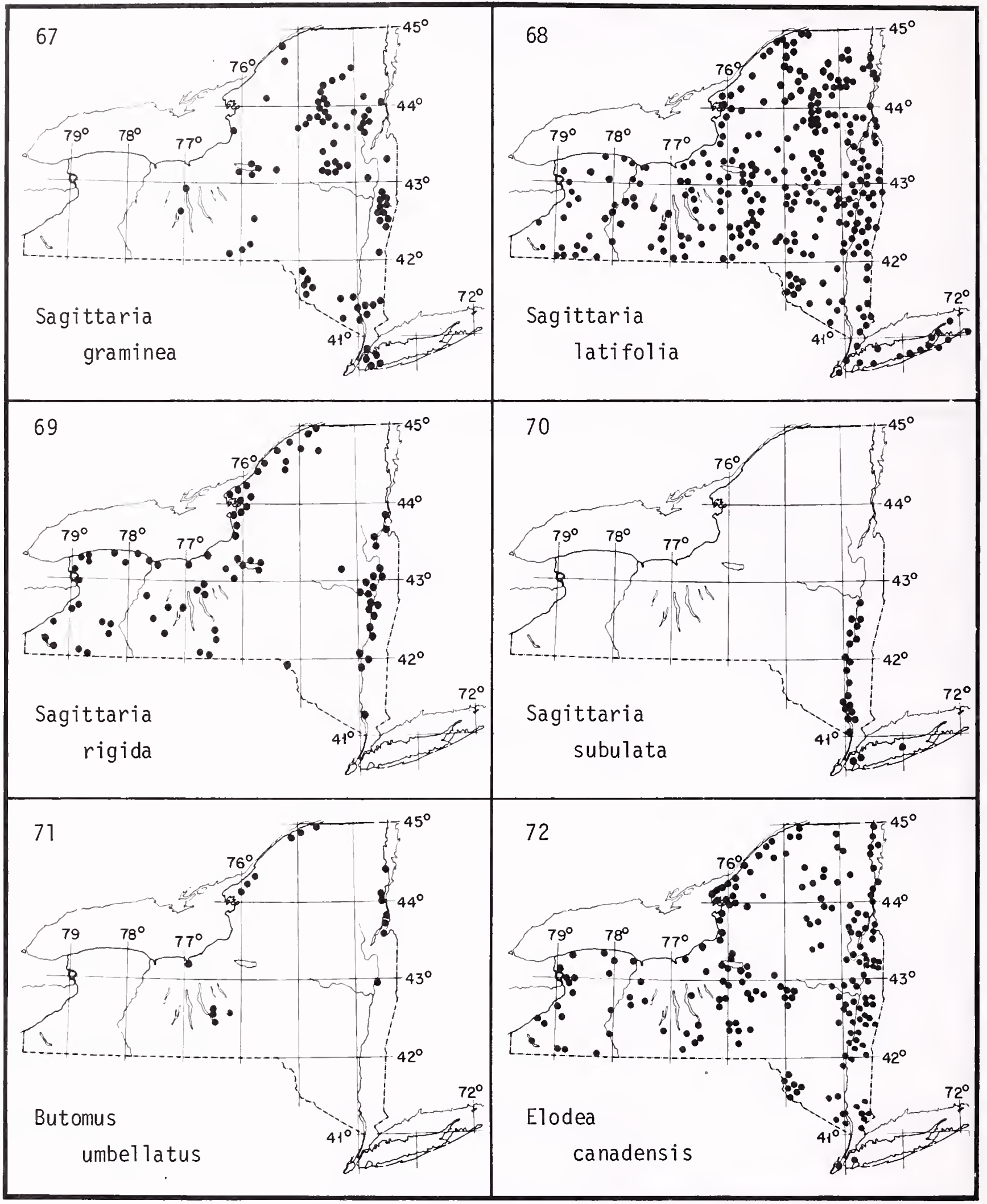




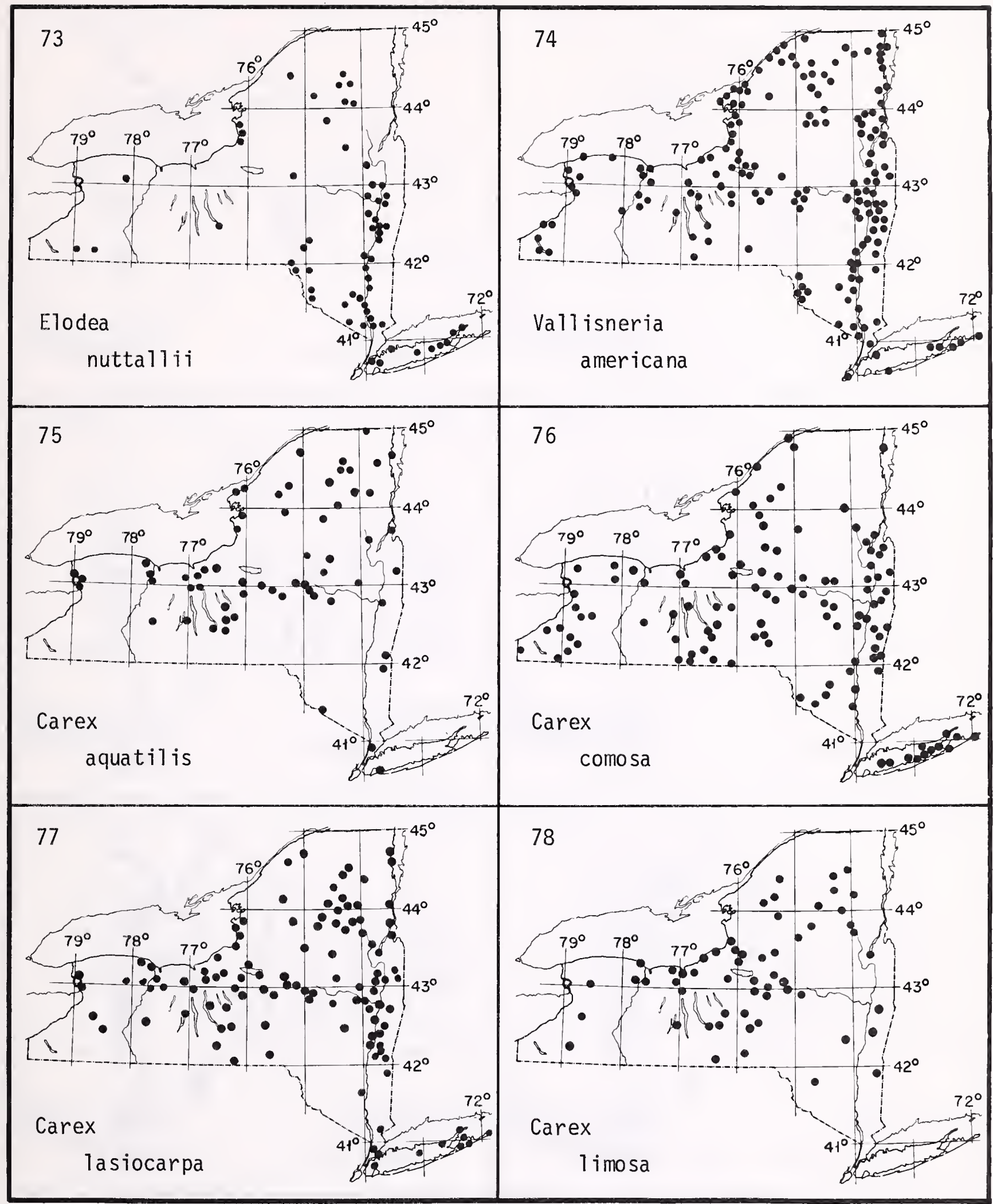




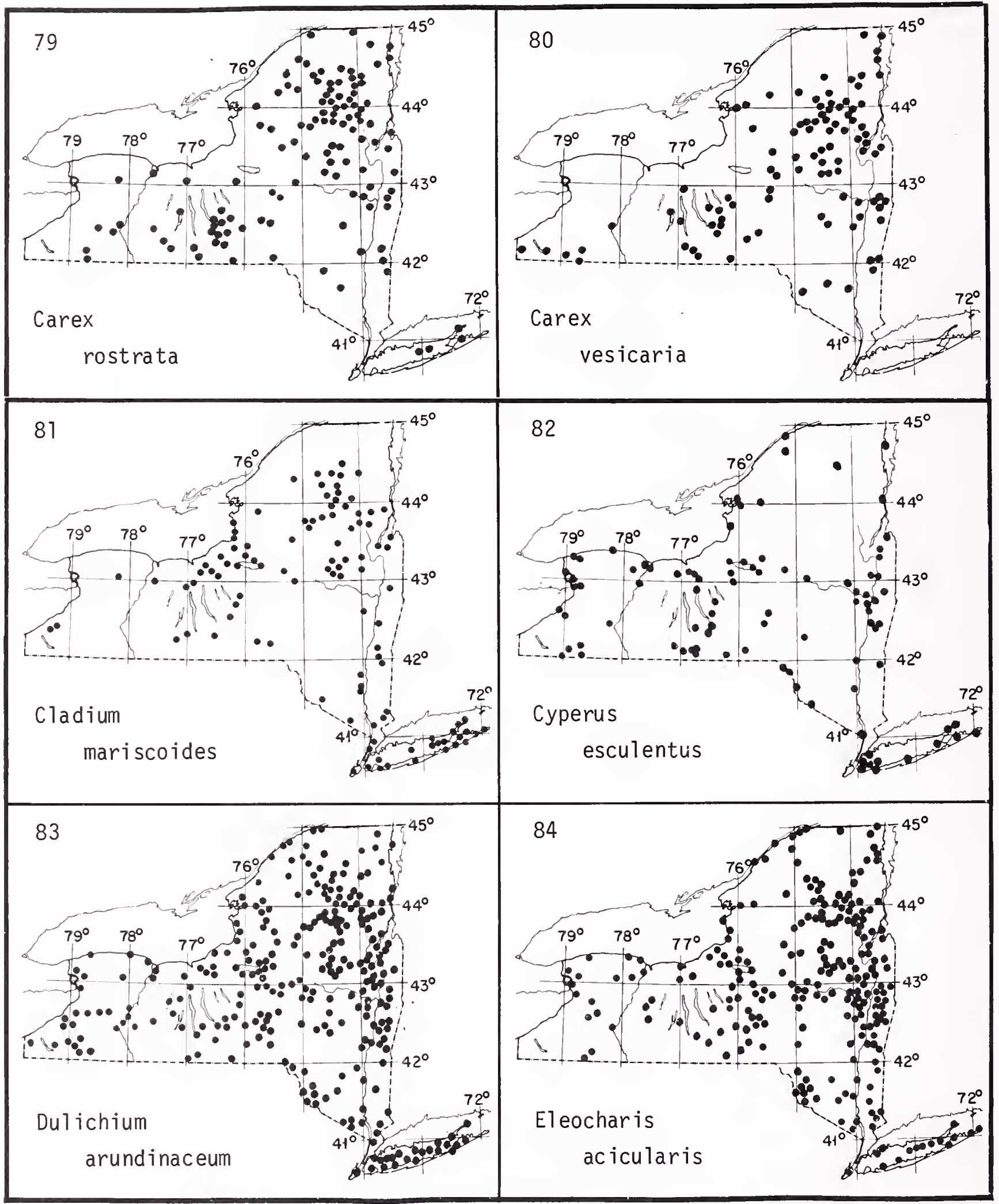




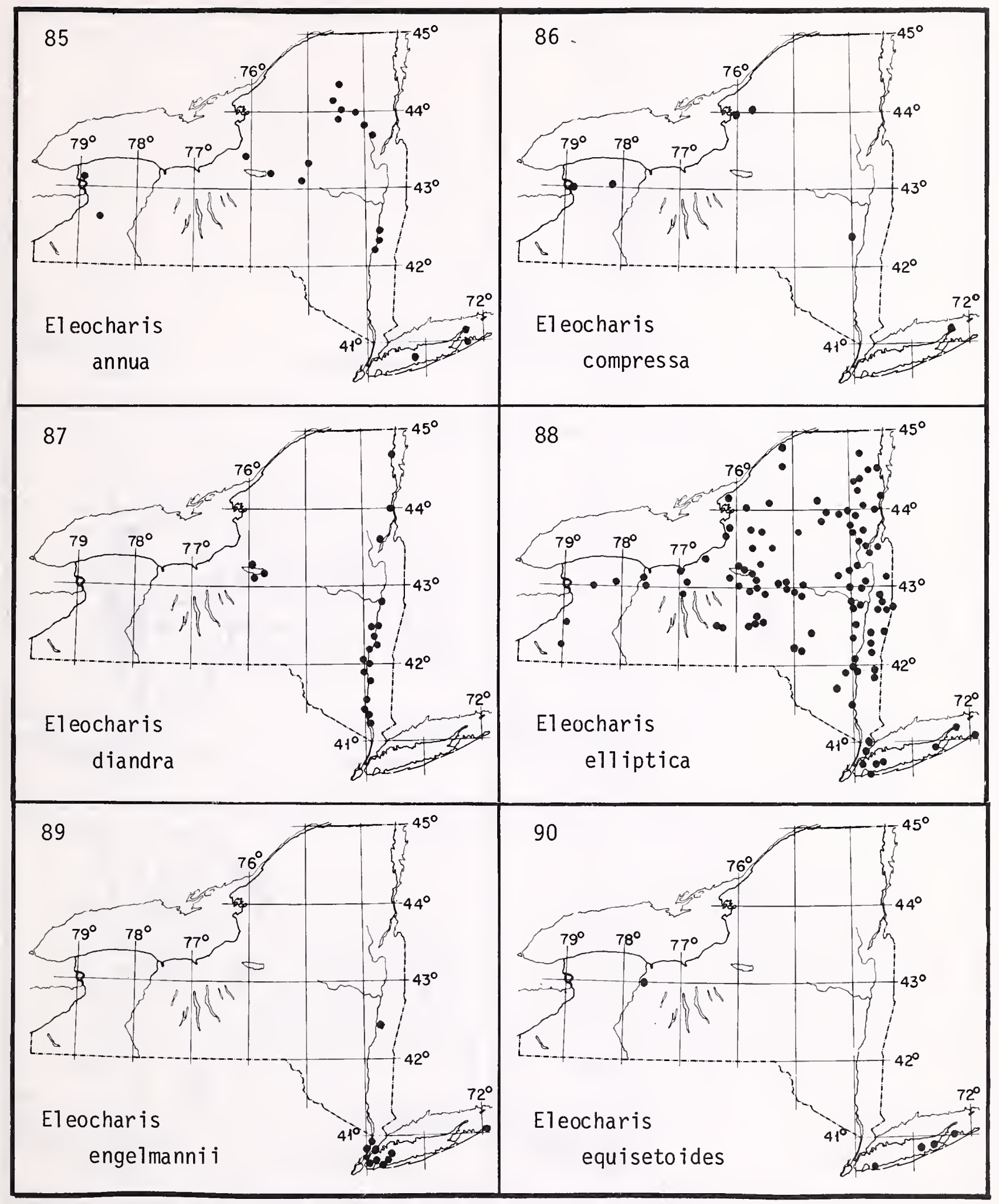




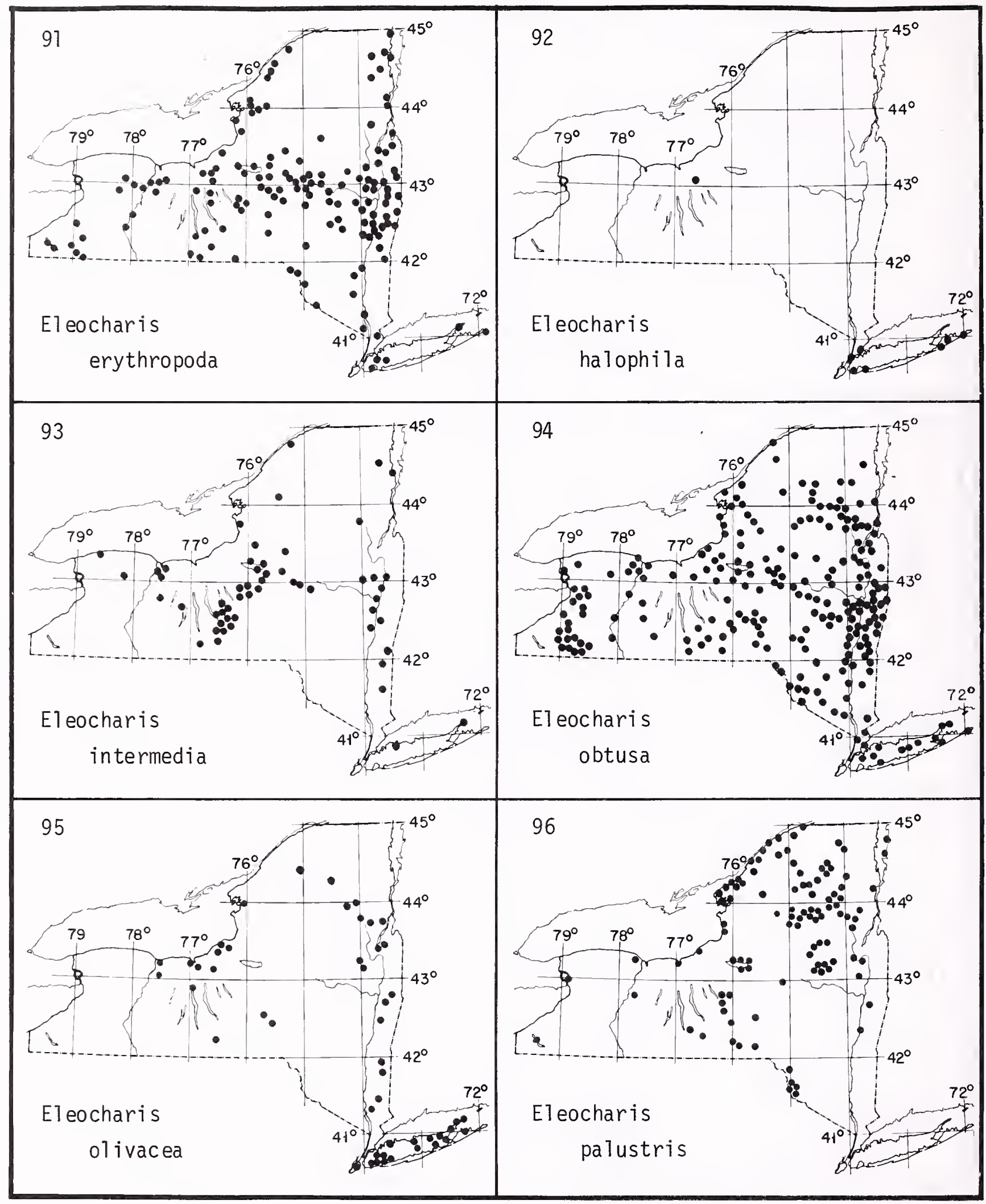




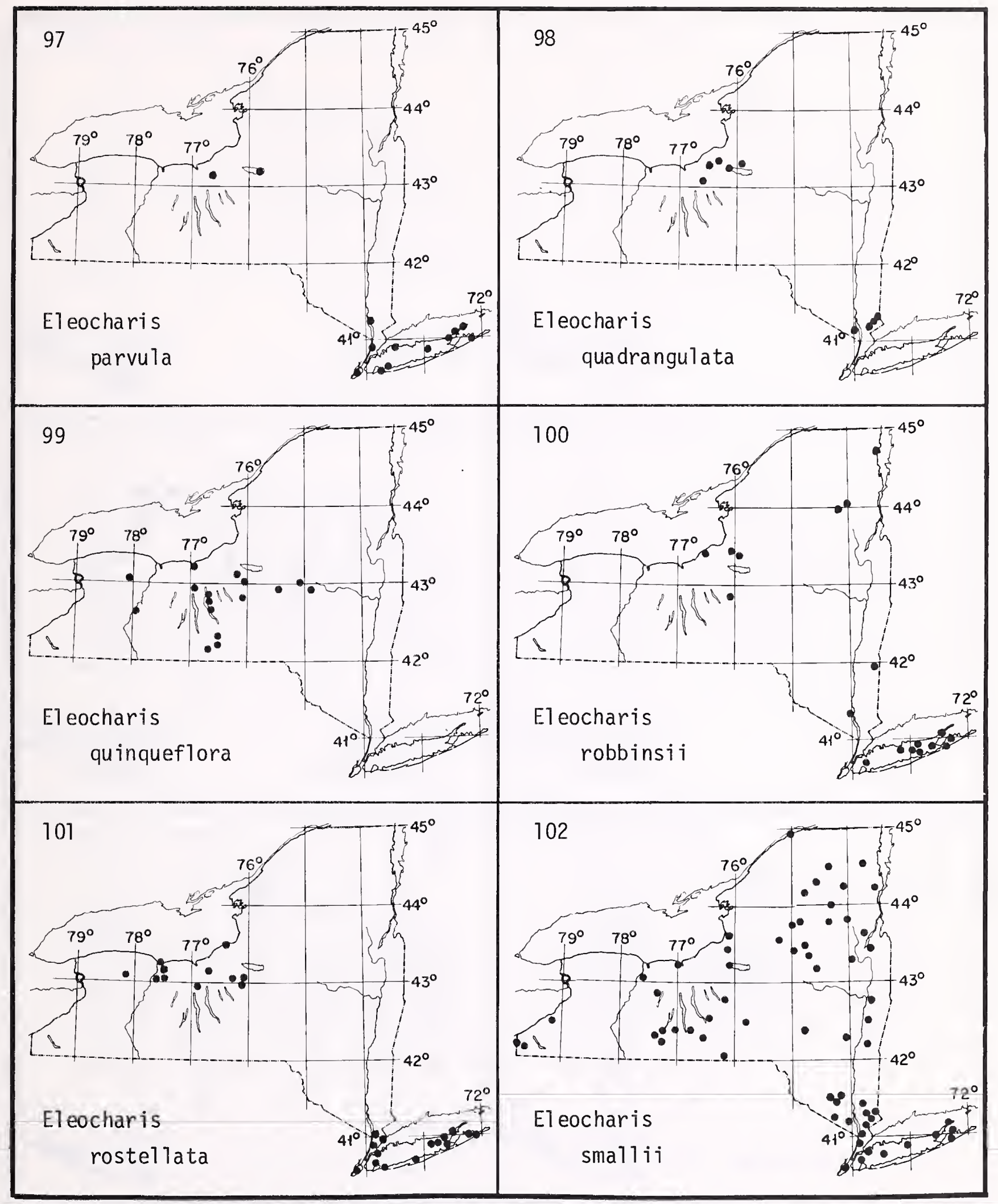




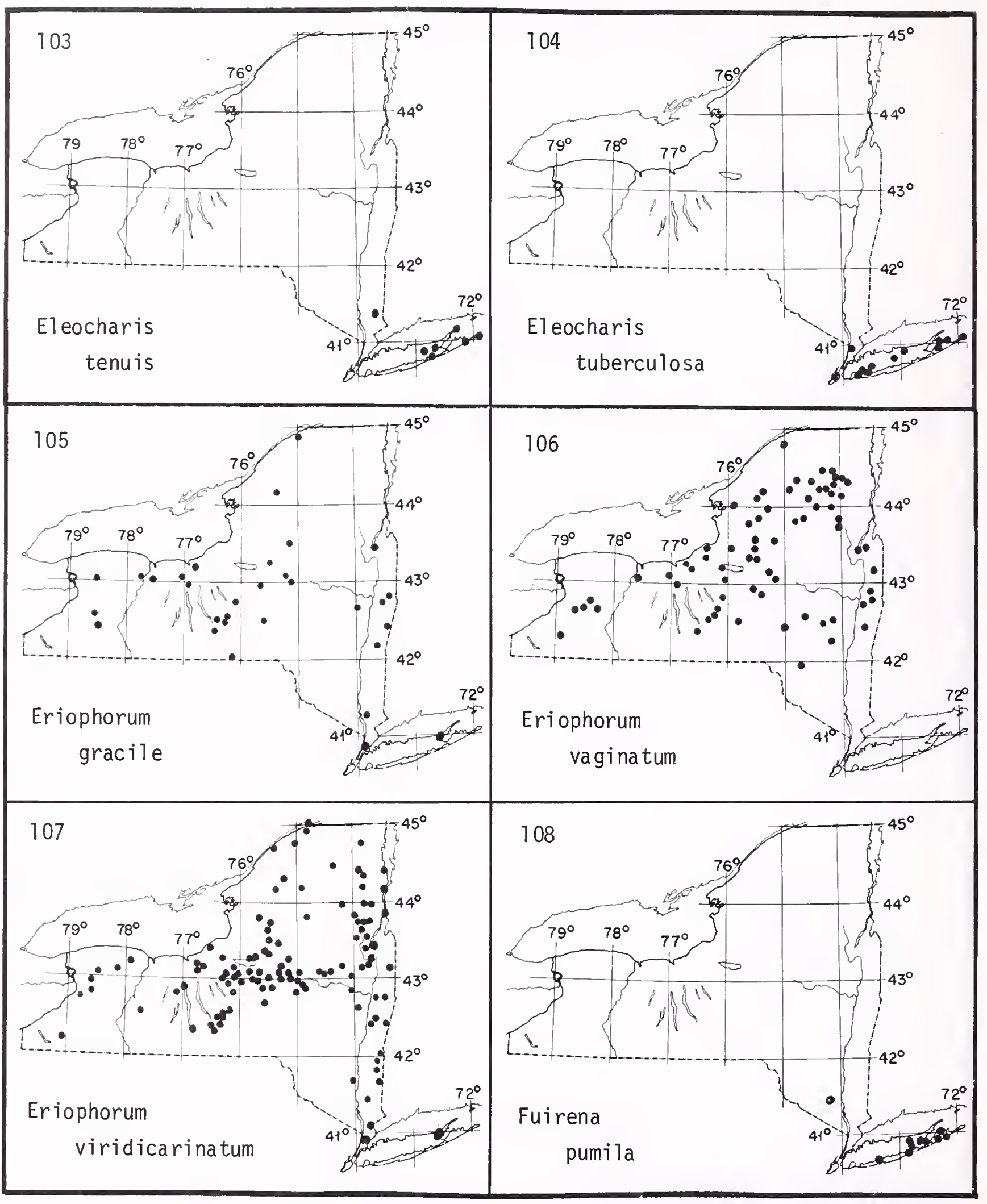




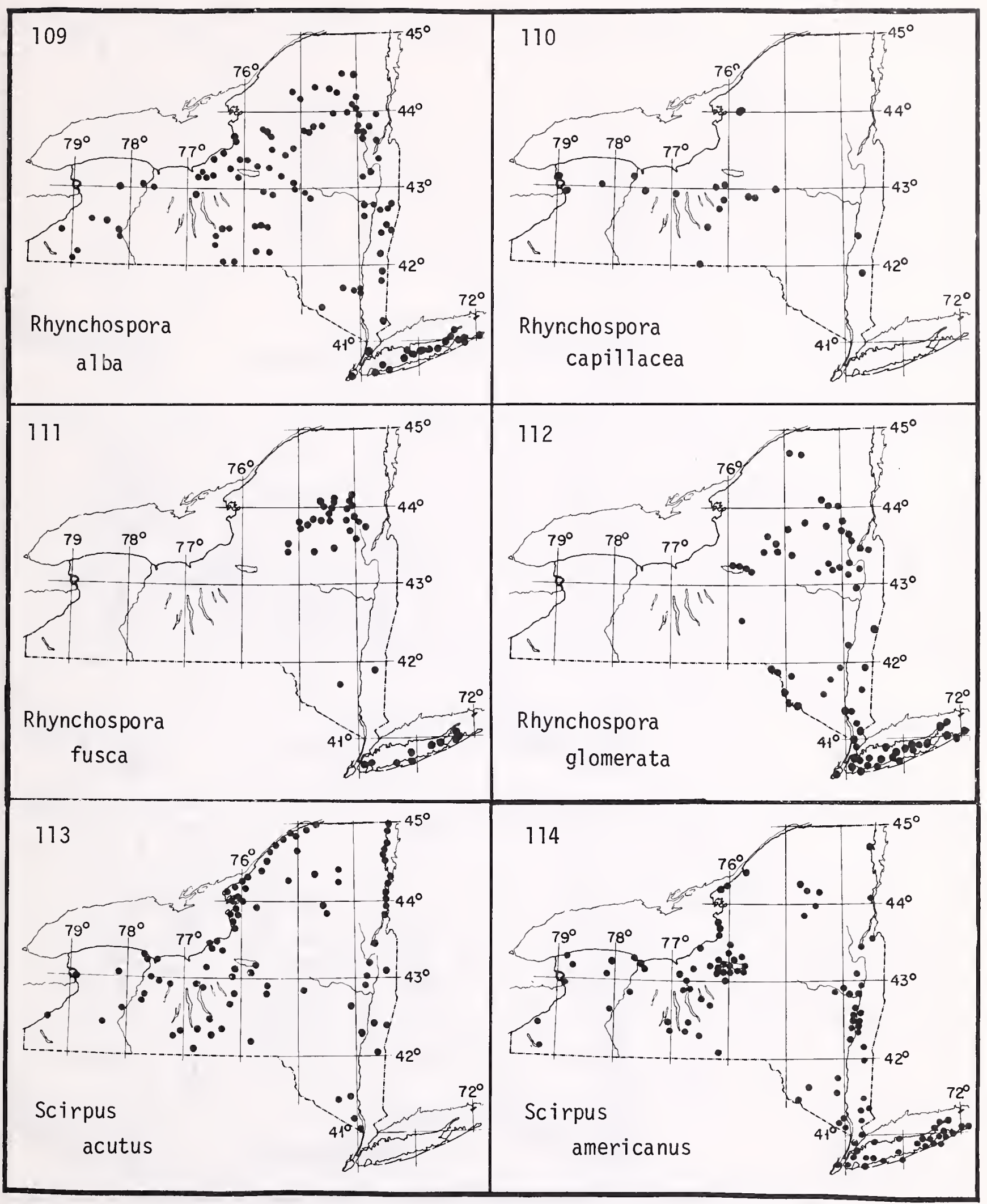




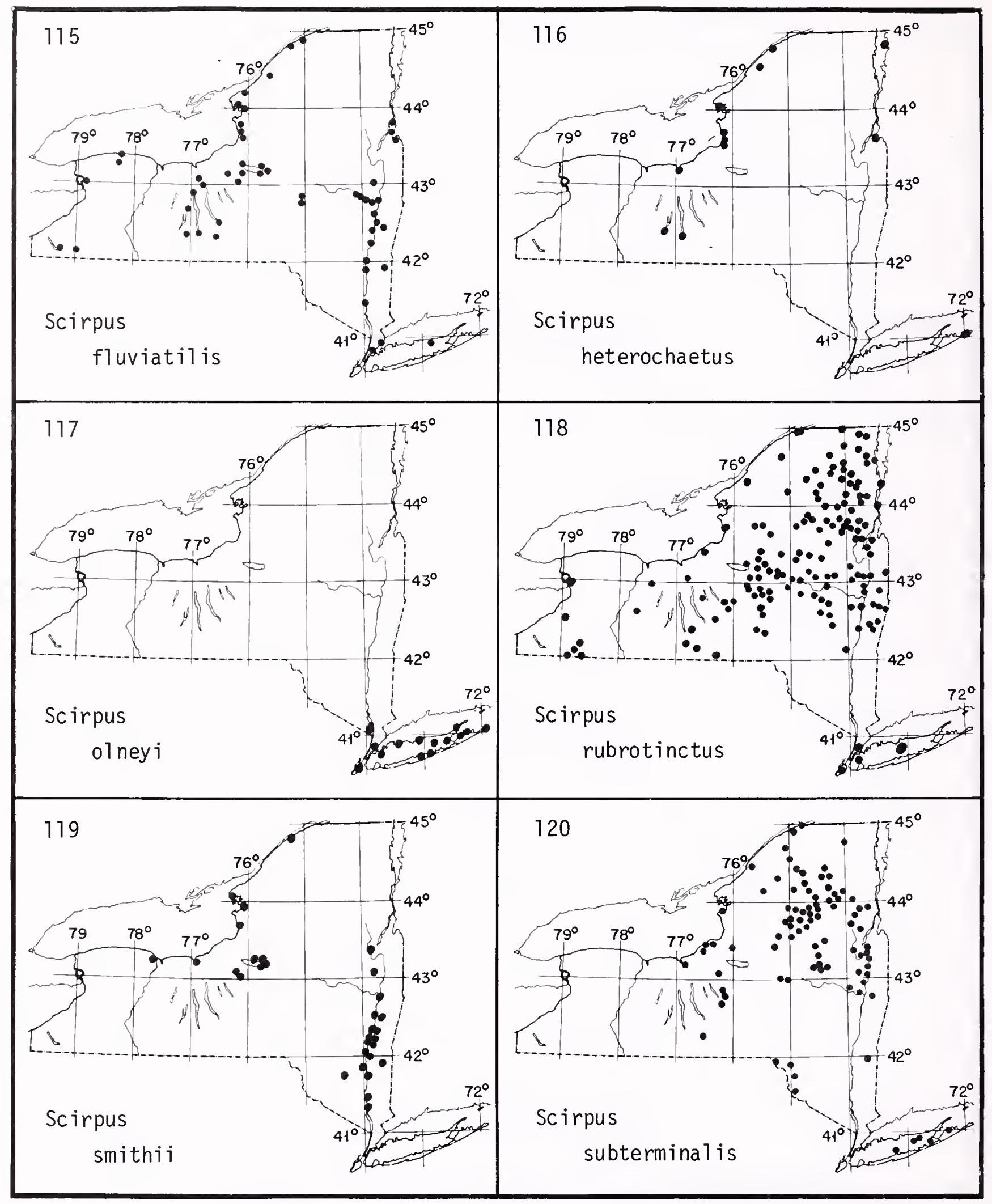




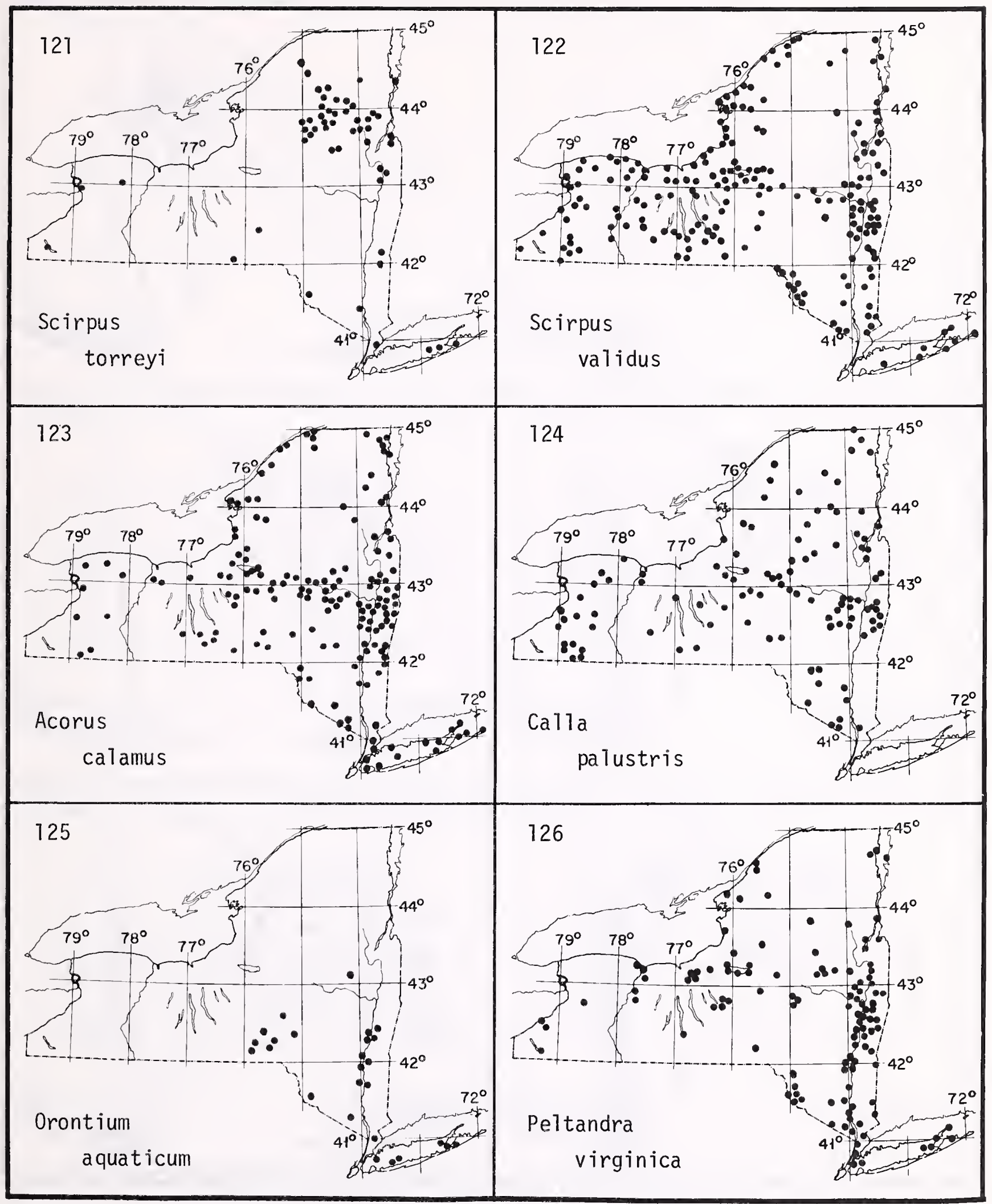




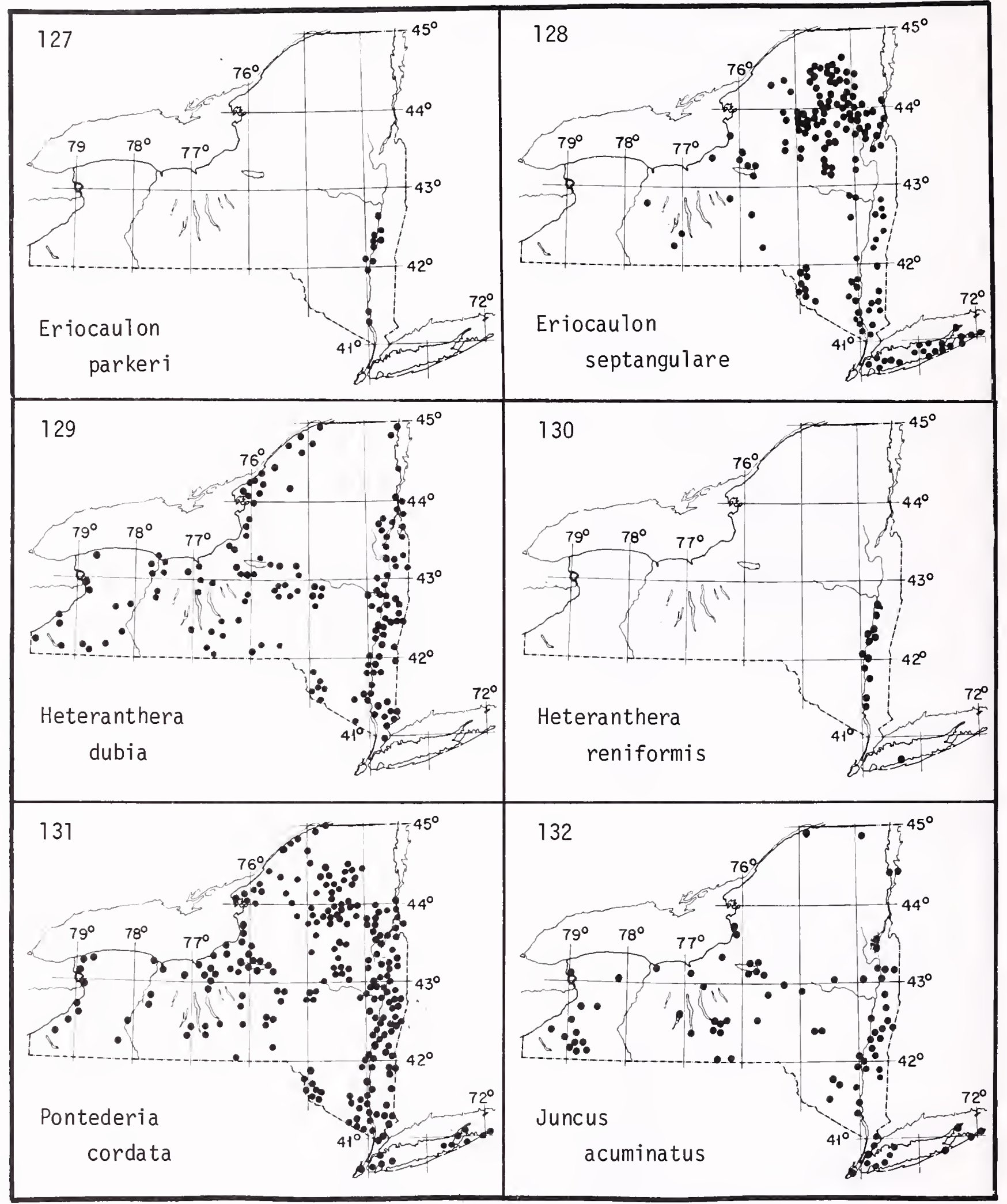




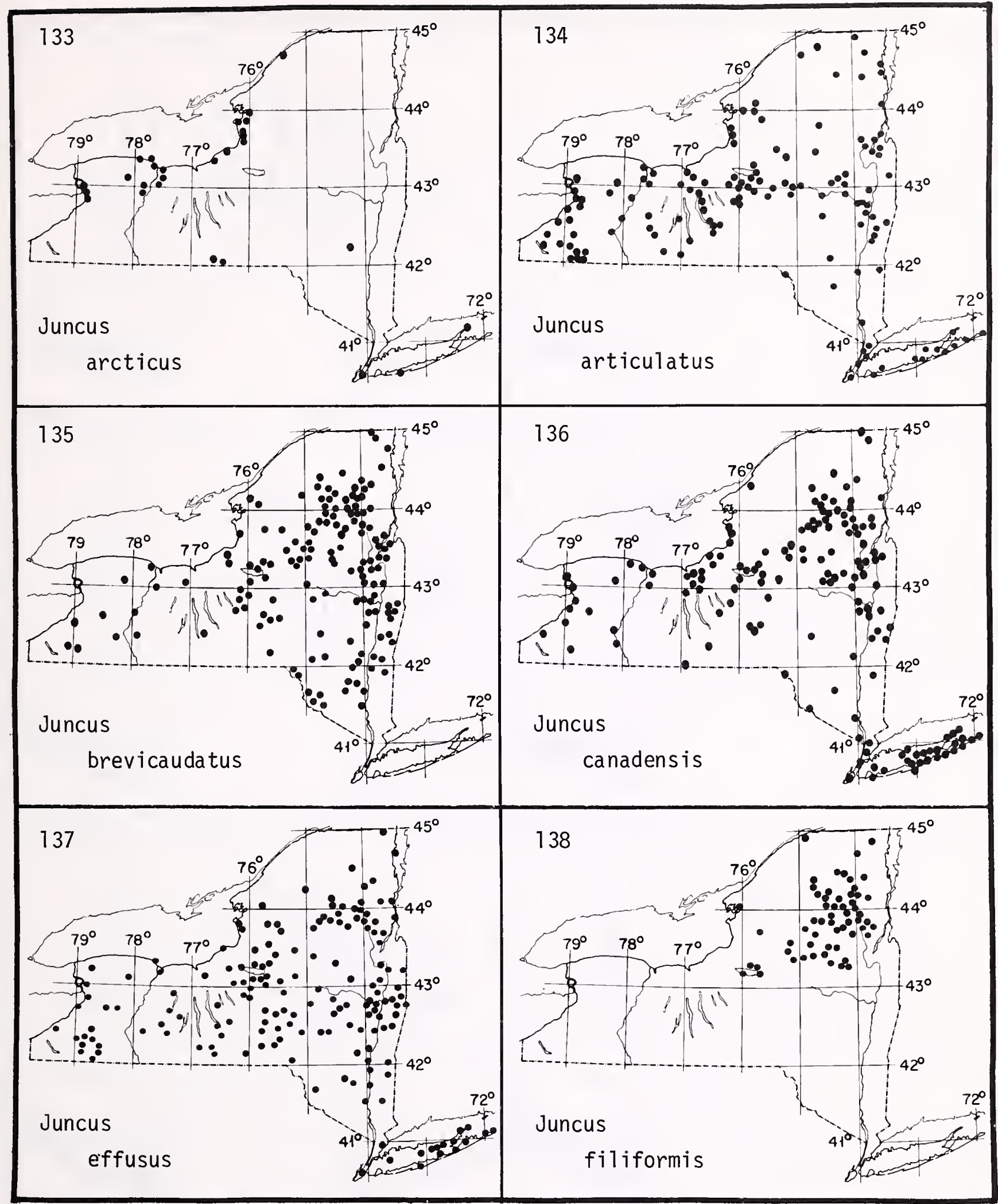




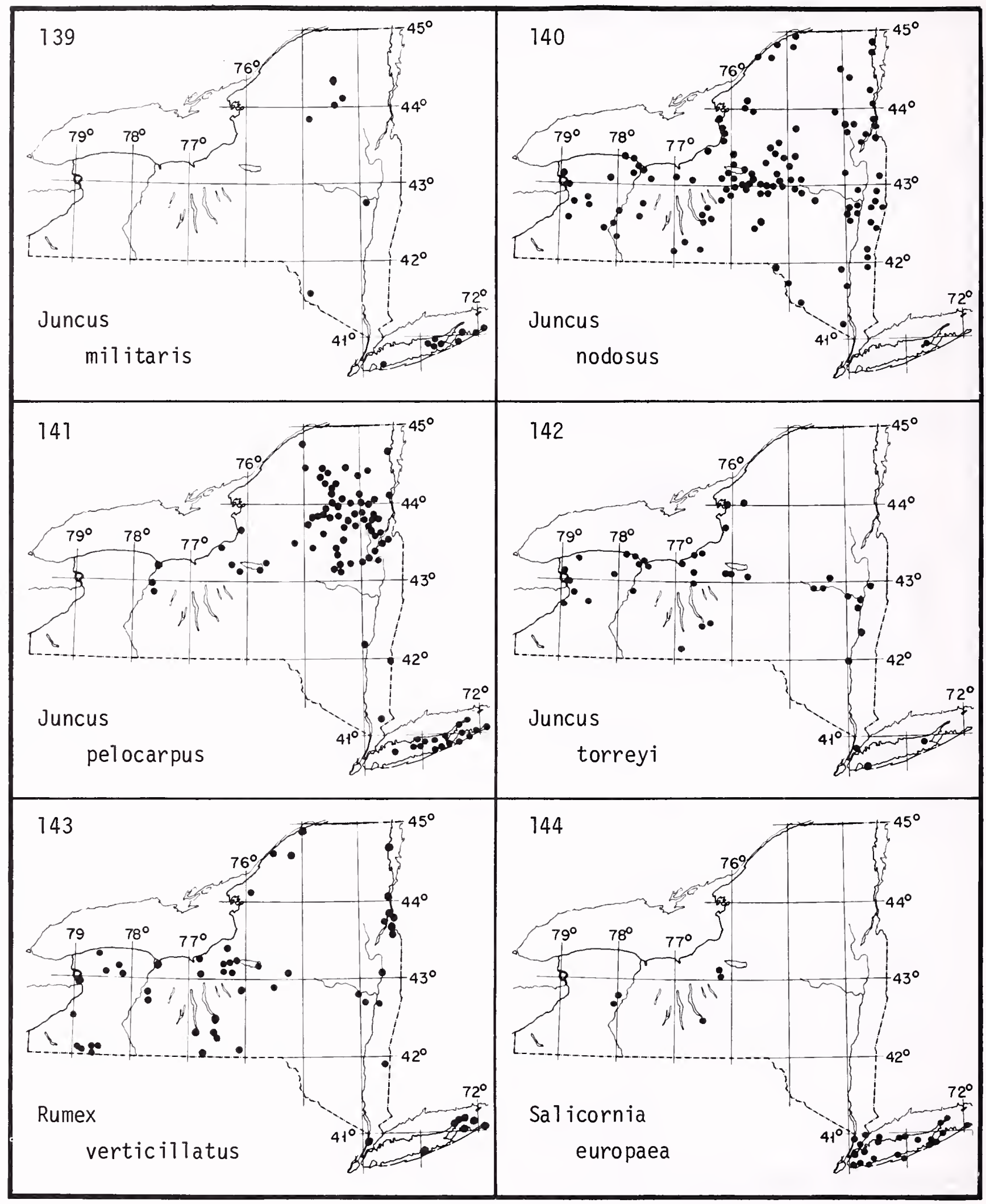




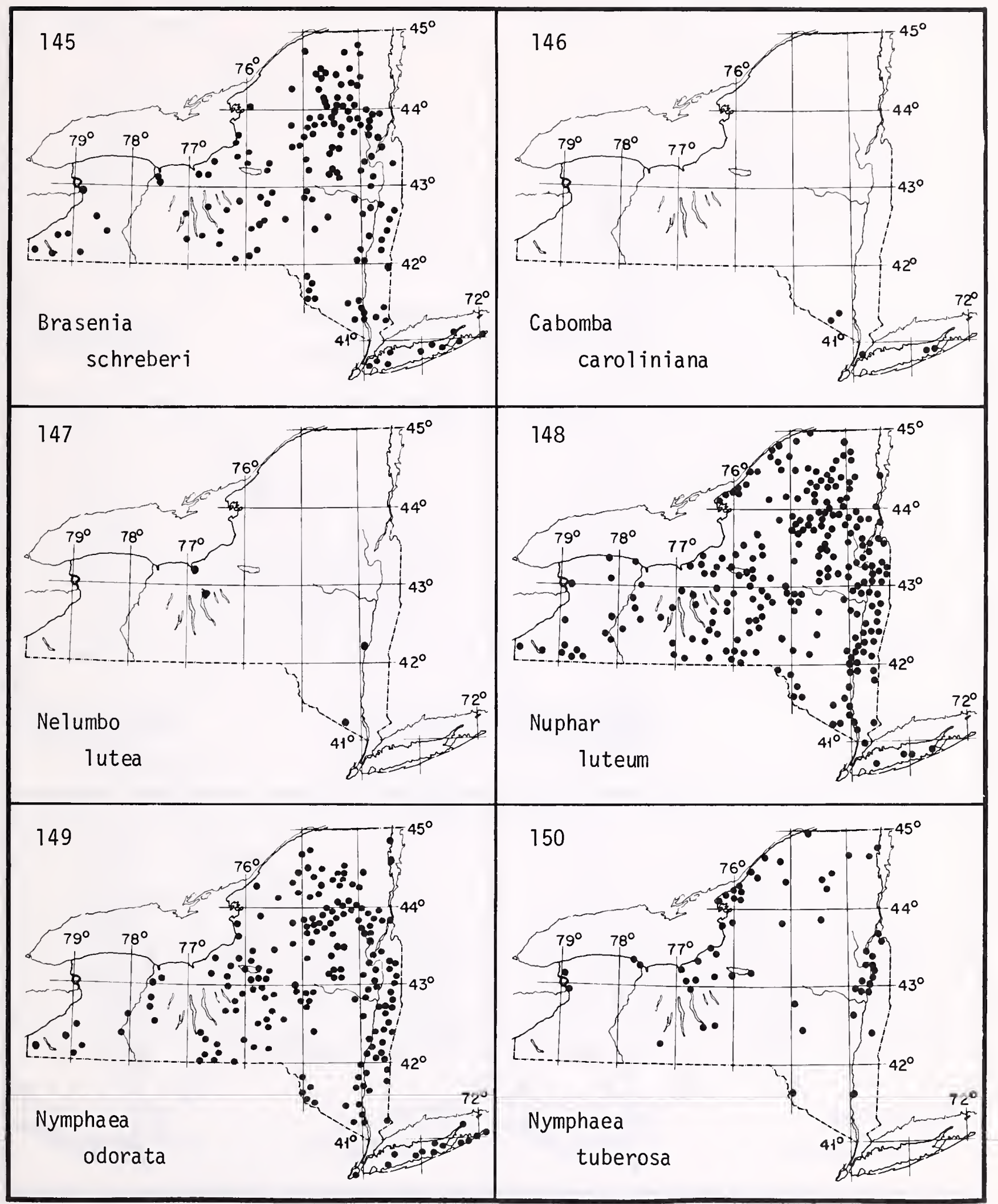




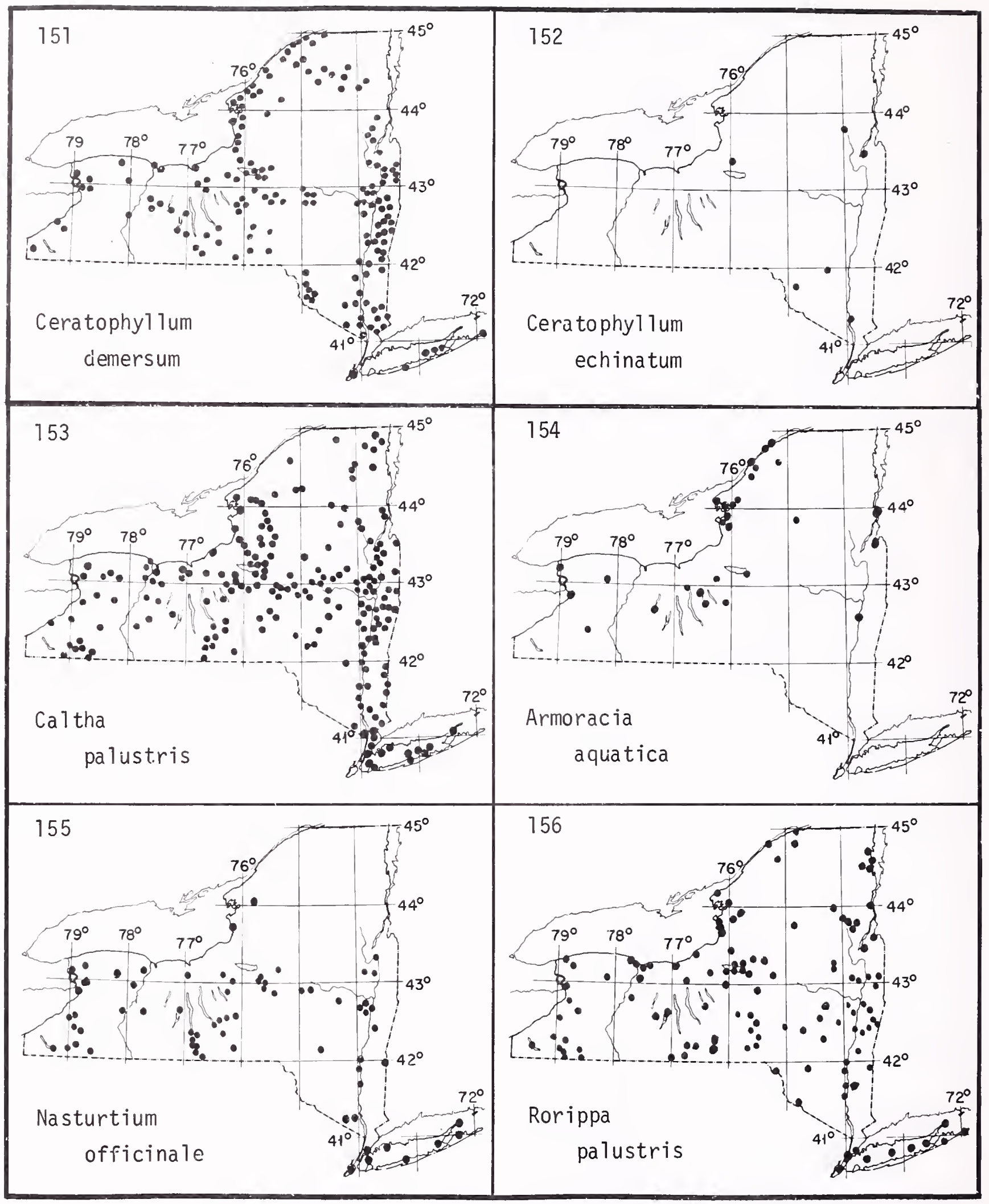




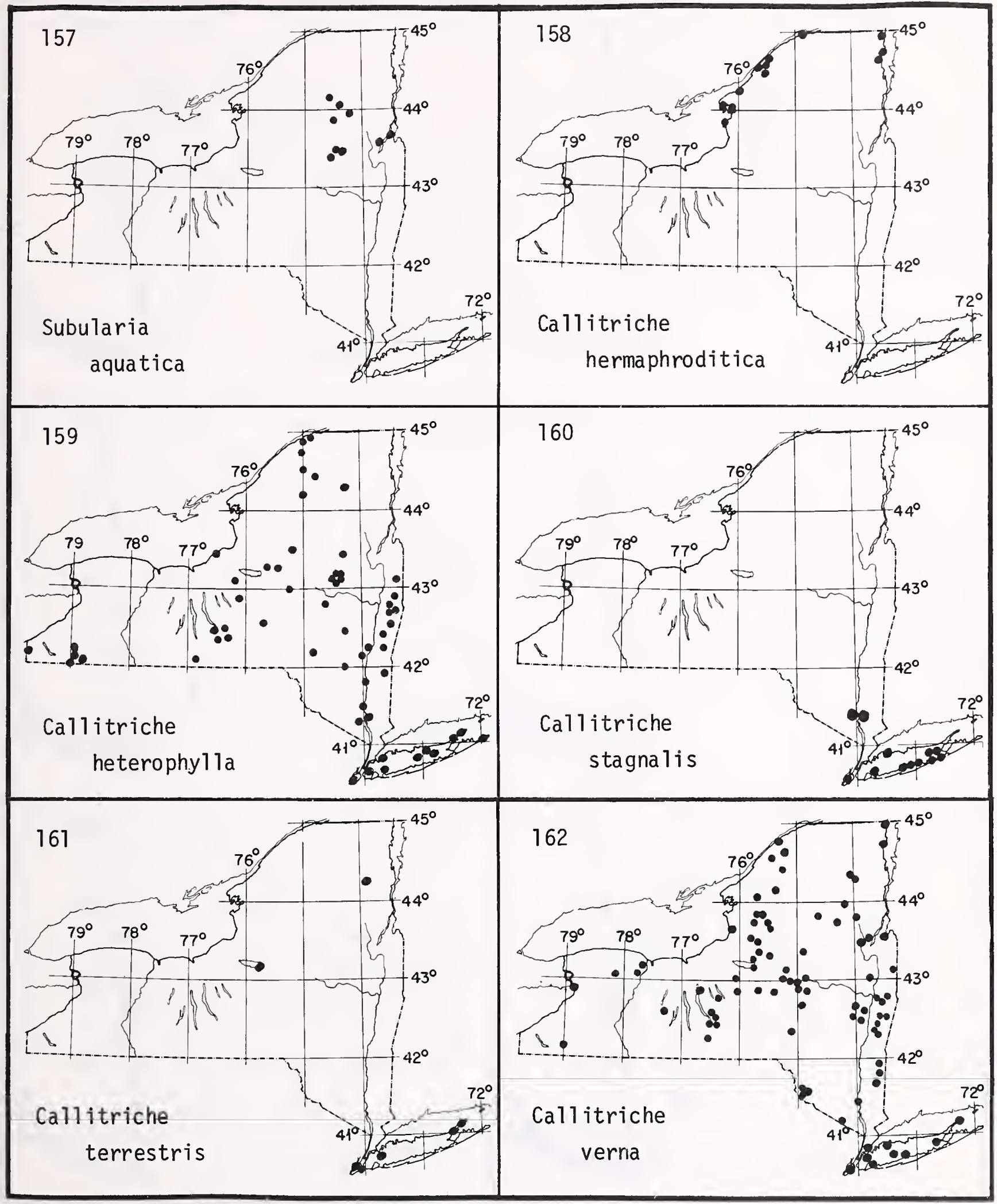




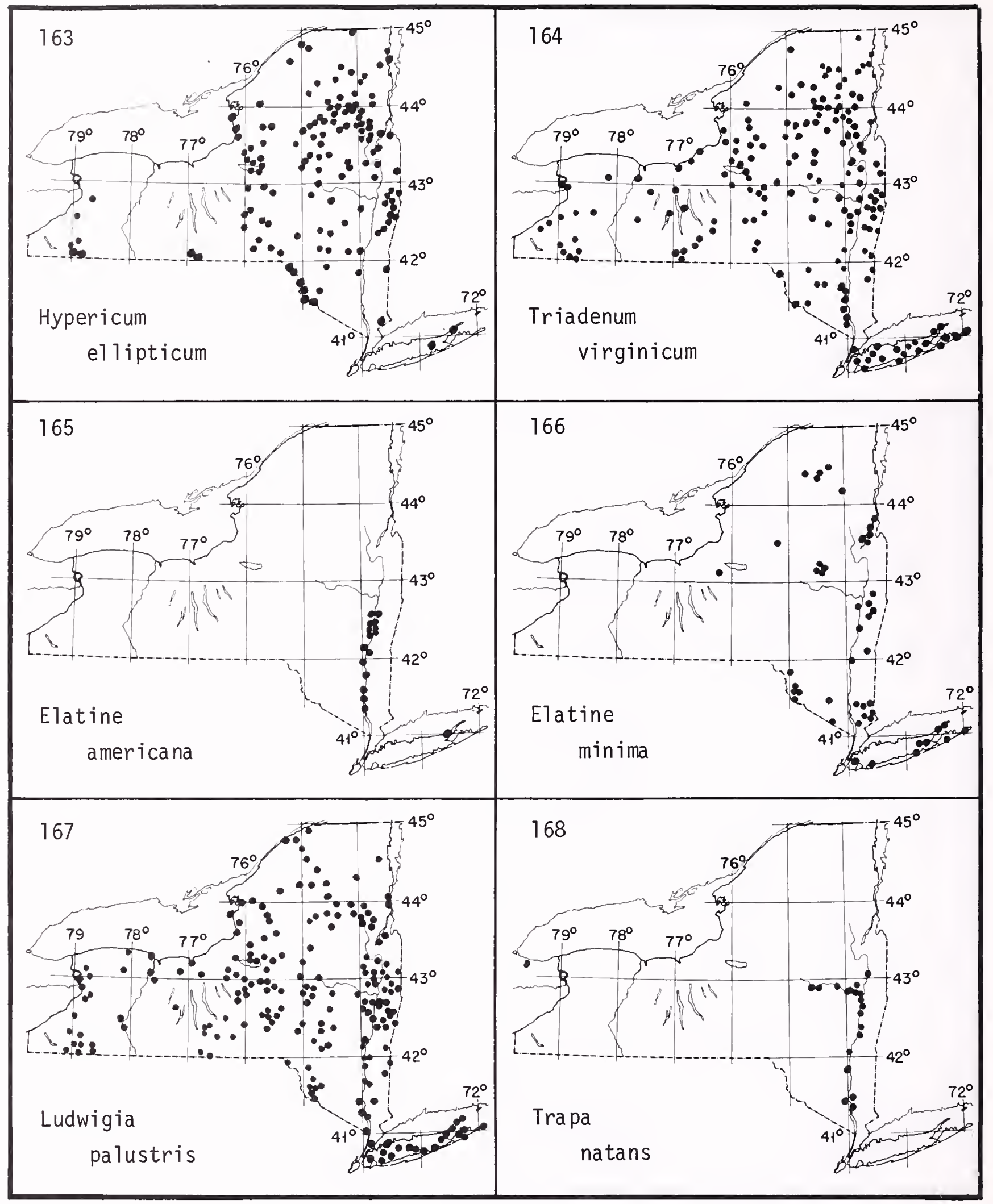




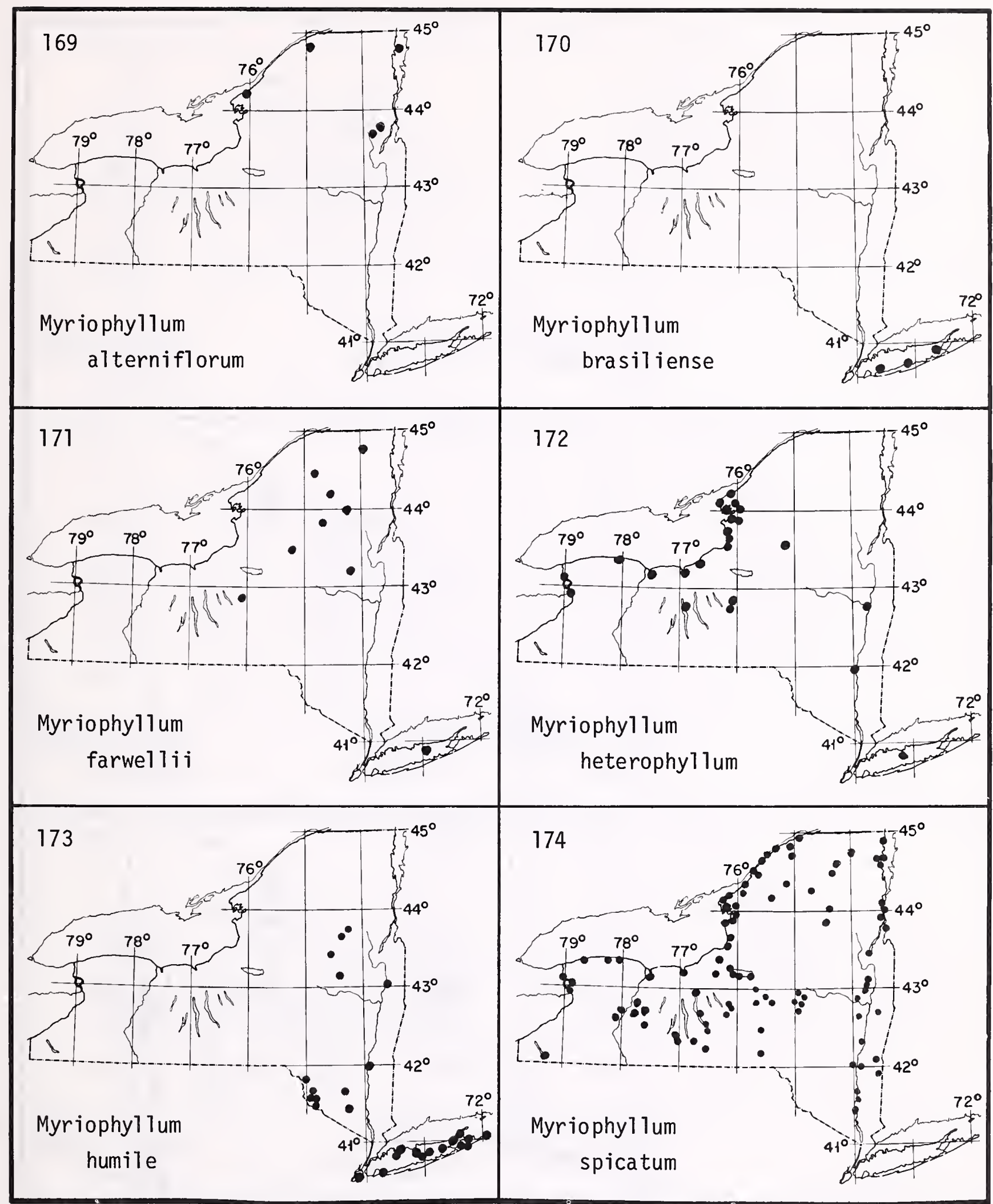




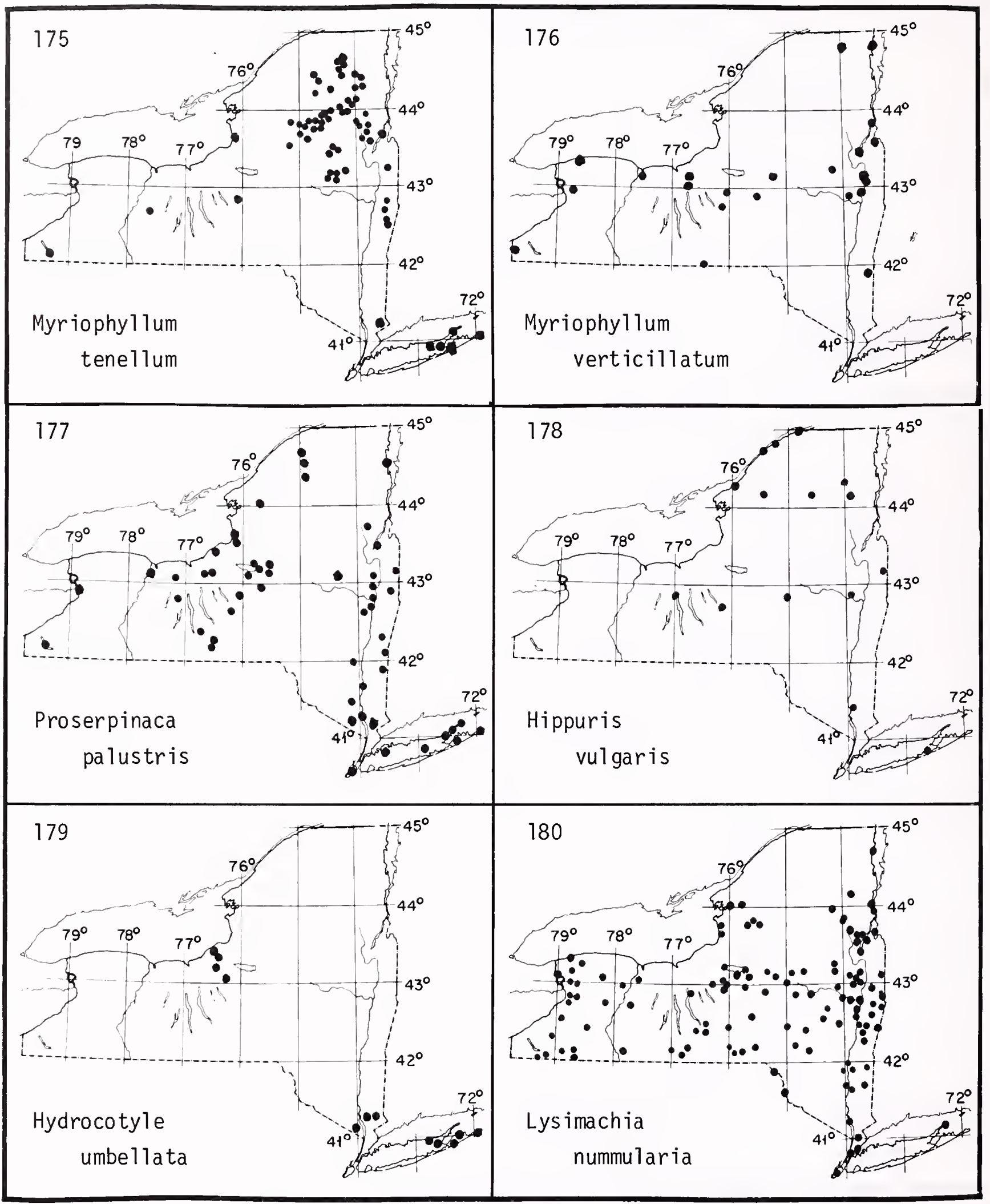




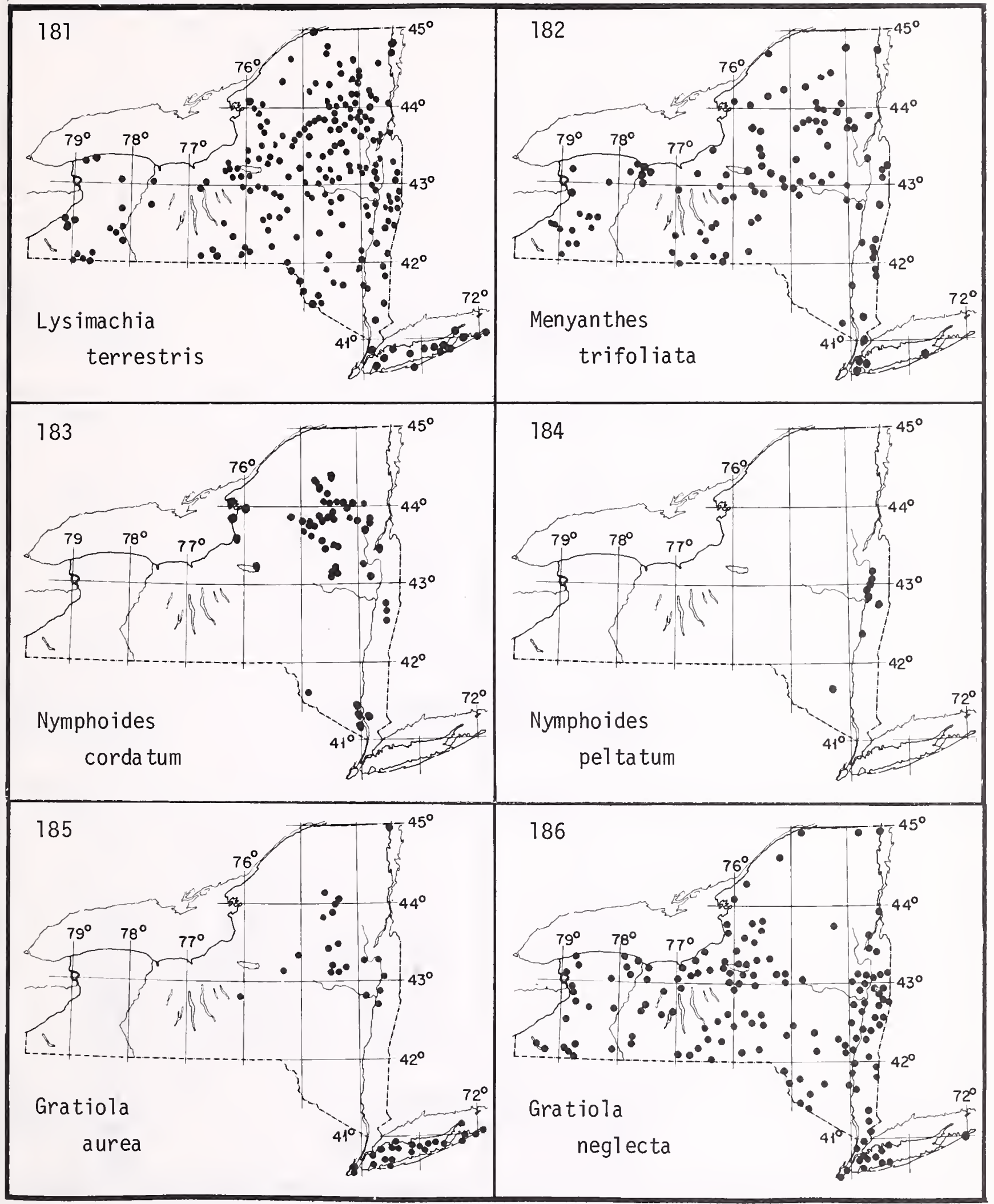




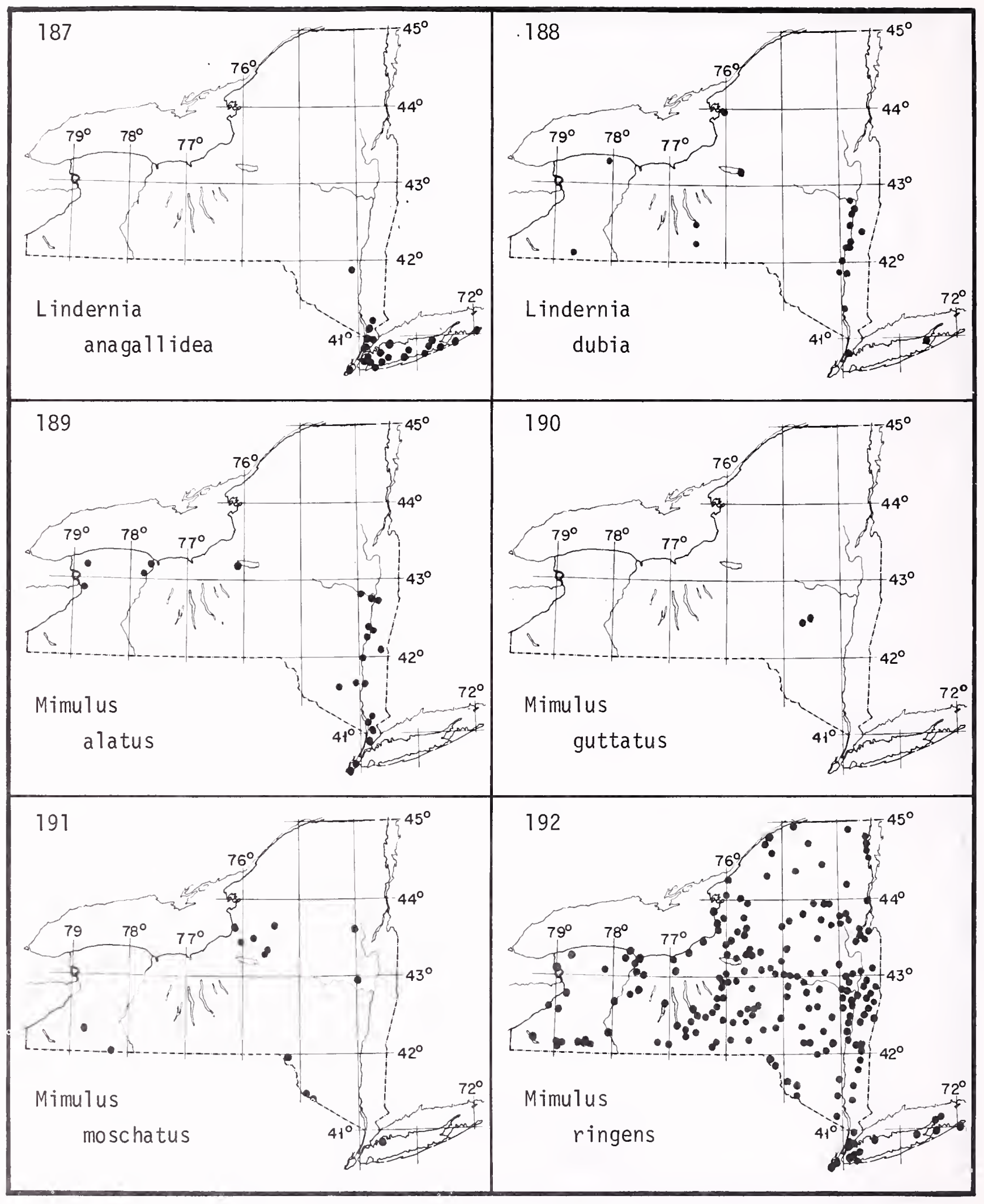




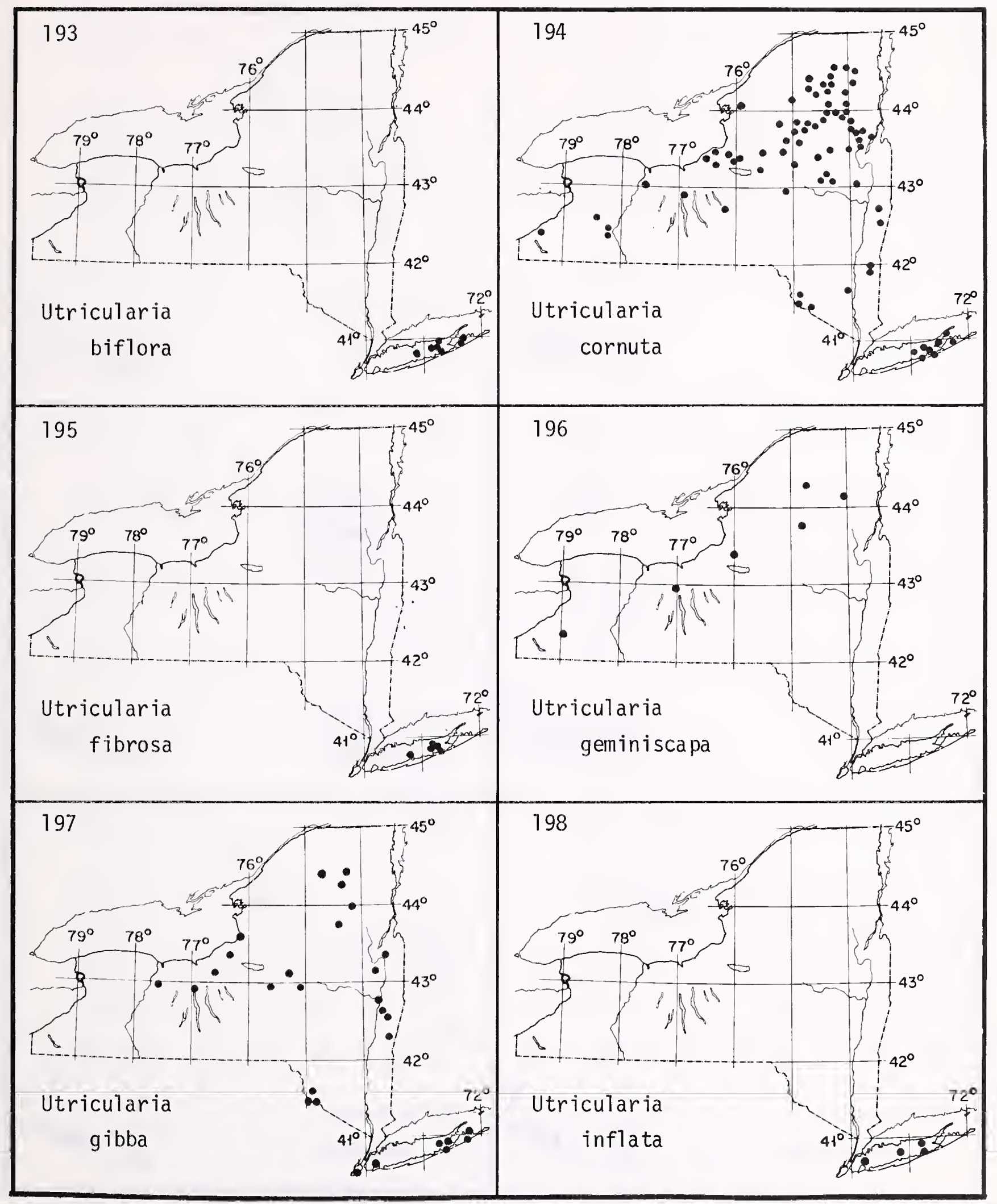




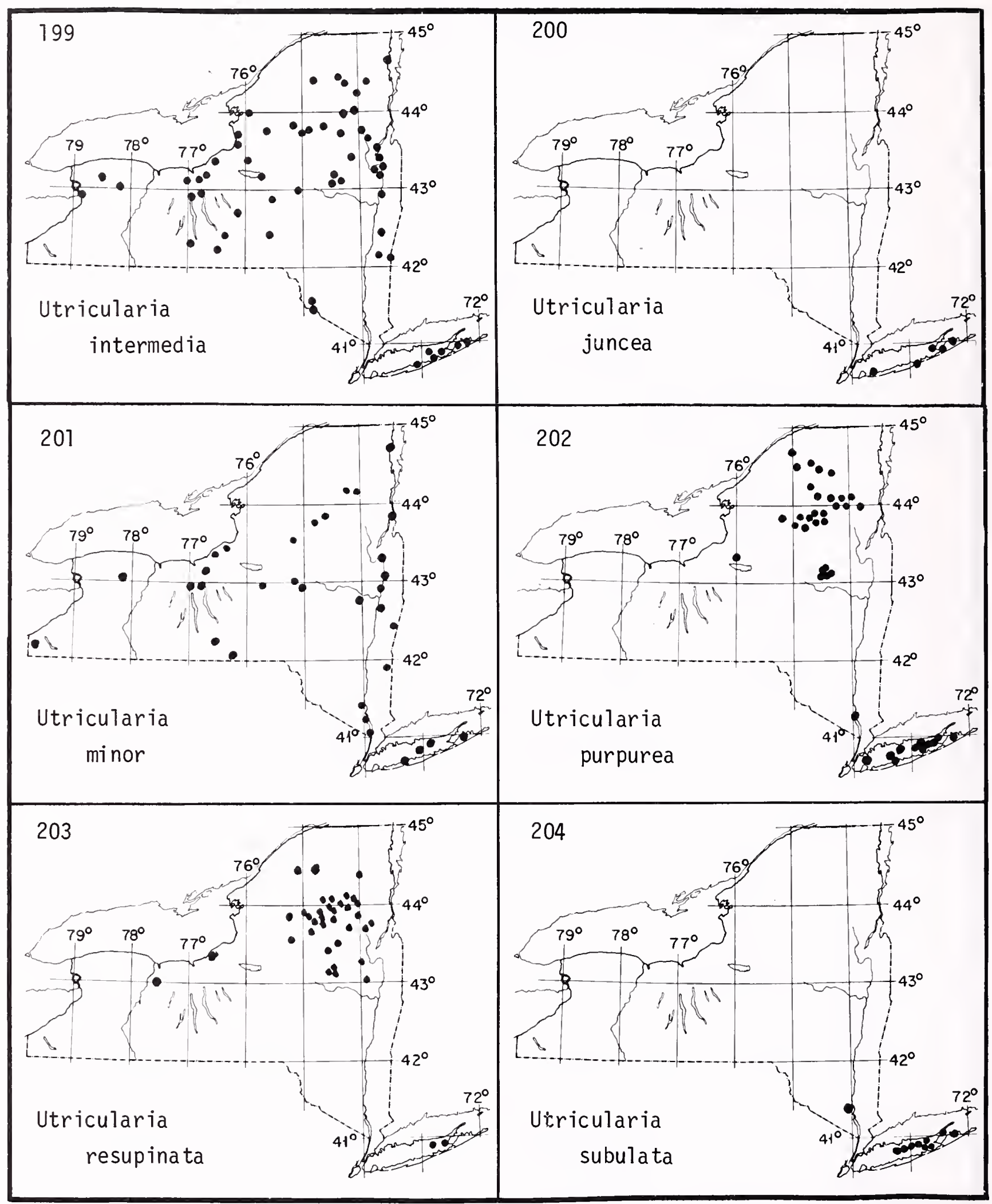




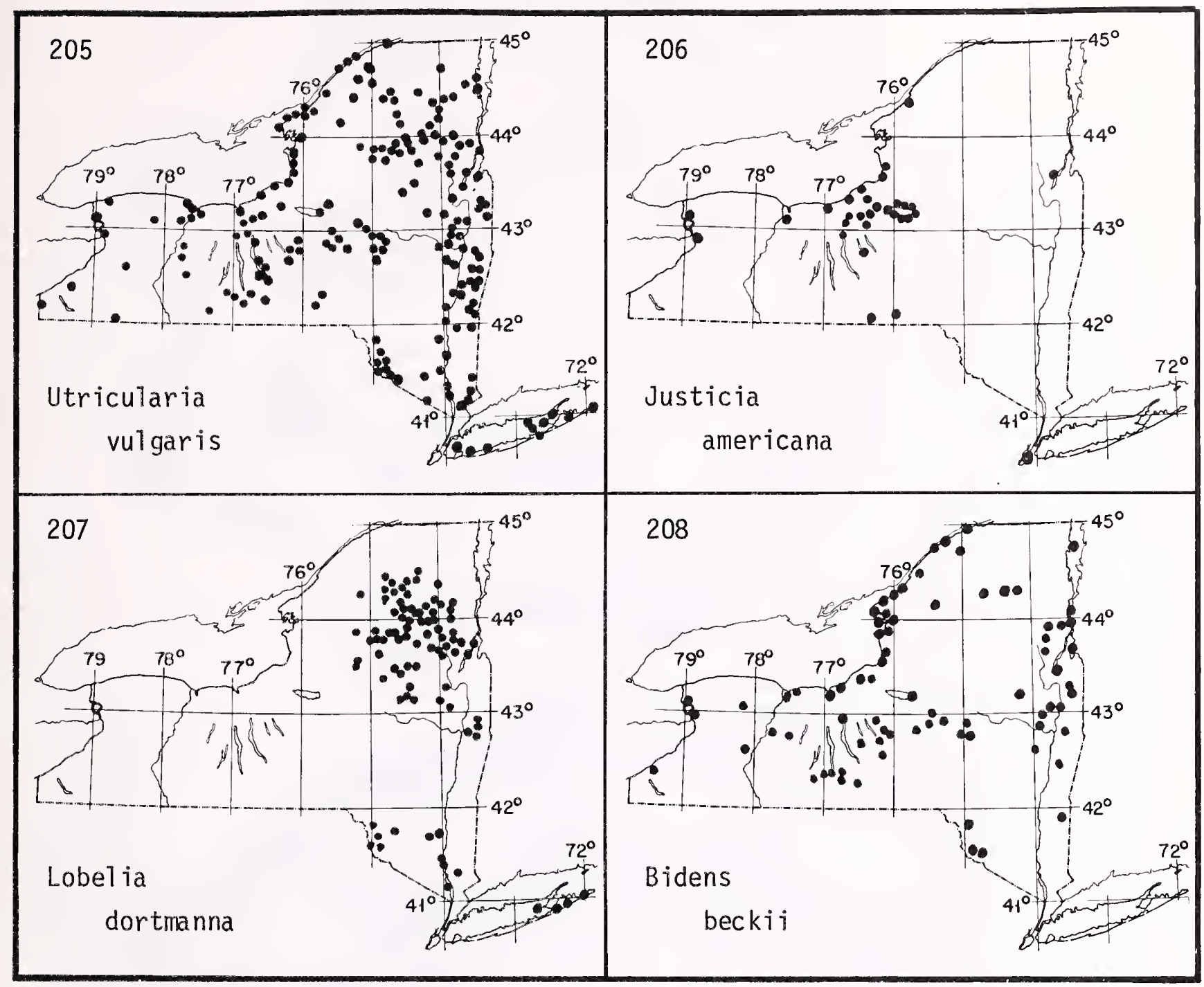




\section{Plates of Drawings}

1. Equisetum arvense Equisetum sylvaticum

2. Equisetum fluviatile Equisetum hyemale

3. Equisetum variegatum Equisetum scirpoides

4. Isoetes echinospora

5. Marsilea quadrifolia

6. Sparganium americanum

7. Sparganium angustifolium

8. Potamogeton crispus Potamogeton foliosus

9. Potamogeton gramineus

10. Potamogeton natans

11. Potamogeton pectinatus

12. Potamogeton perfoliatus

13. Potamogeton pulcher

14. Potamogeton zosteriformis

15. Ruppia maritima

16. Zannichellia palustris

17. Najas flexilis

18. Scheuchzeria palustris

19. Alisma plantago-aquatica

20. Sagittaria latifolia

21. Sagittaria latifolia

22. Butomus umbellatus

23. Butomus umbellatus

24. Elodea canadensis

25. Vallisneria americana

26. Carex comosa Fuirena squarosa

27. Cladium mariscoides

28. Dulichium arundinaceum

29. Eleocharis palustris

30. Eriophorum vaginatum

31. Rhynchospora alba

32. Scirpus americanus

33. Scirpus validus
34. Acorus calamus

35. Calla palustris

36. Peltandra virginica

37. Eriocaulon septangulare

38. Heteranthera dubia

39. Pontederia cordata

40. Juncus articulatus

41. Juncus effusus

42. Brasenia schreberi

43. Cabomba caroliniana

44. Nuphar luteum

45. Nymphaea odorata

46. Ceratophyllum demersum

47. Caltha palustris

48. Armoracia aquatica

49. Nasturtium officinale

50. Hypericum ellipticum Triadenum virginicum

51. Ludwigia palustris

52. Trapa natans

53. Trapa natans

54. Myriophyllum brasiliense

55. Myriophyllum spicatum

56. Hippuris vulgaris Proserpinaca palustris

57. Hydrocotyle umbellata

58. Lysimachia terrestris

59. Menyanthes trifoliata

60. Nymphoides cordatum Nymphoides peltatum

61. Gratiola aurea

62. Lindernia dubia

63. Mimulus ringens

64. Utricularia vulgaris

65. Justicia americana

66. Lobelia dortmanna

67. Bidens beckii 


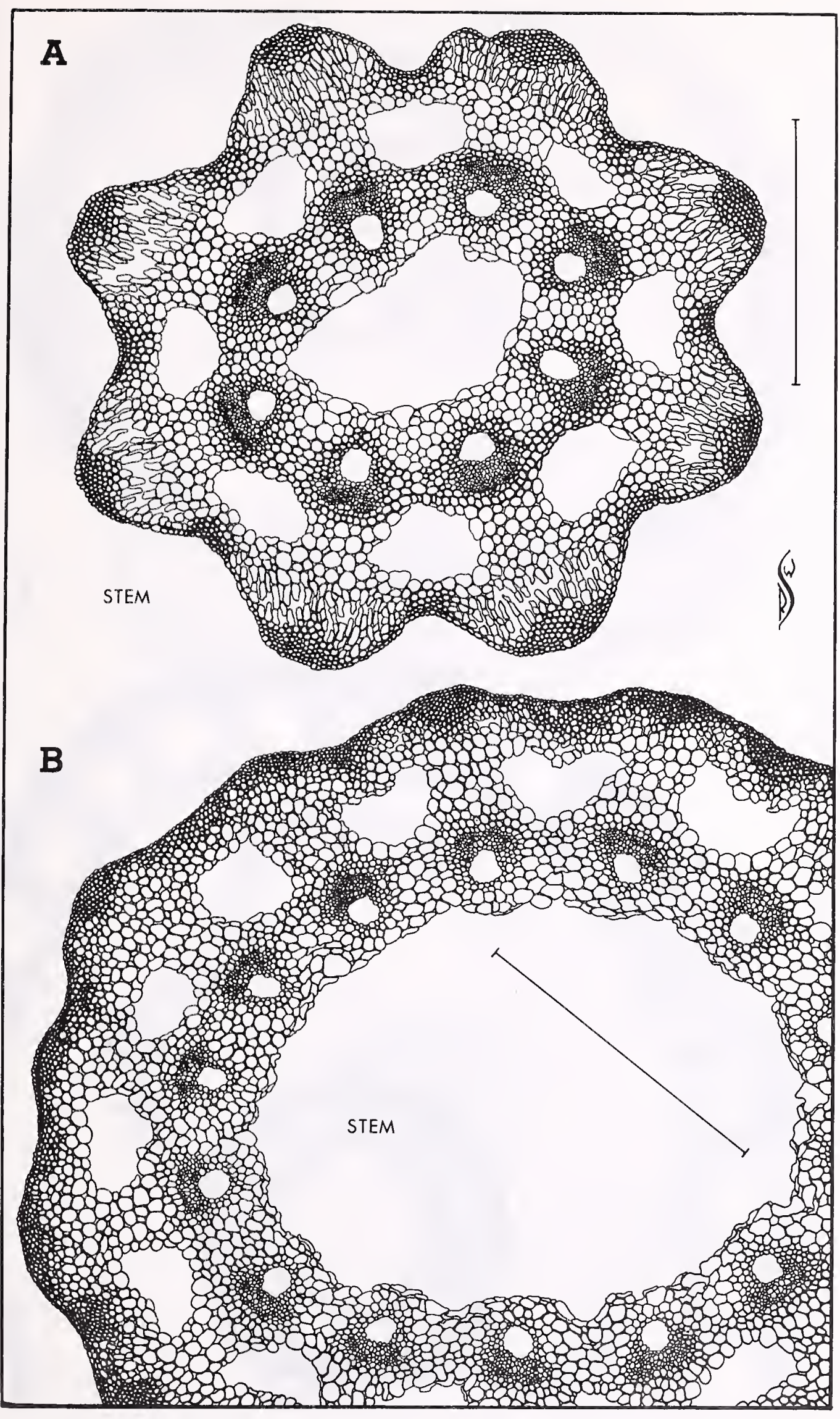

Plate 1

EQUISETUM

E. arvense (A)

E. sylvaticum (B) 


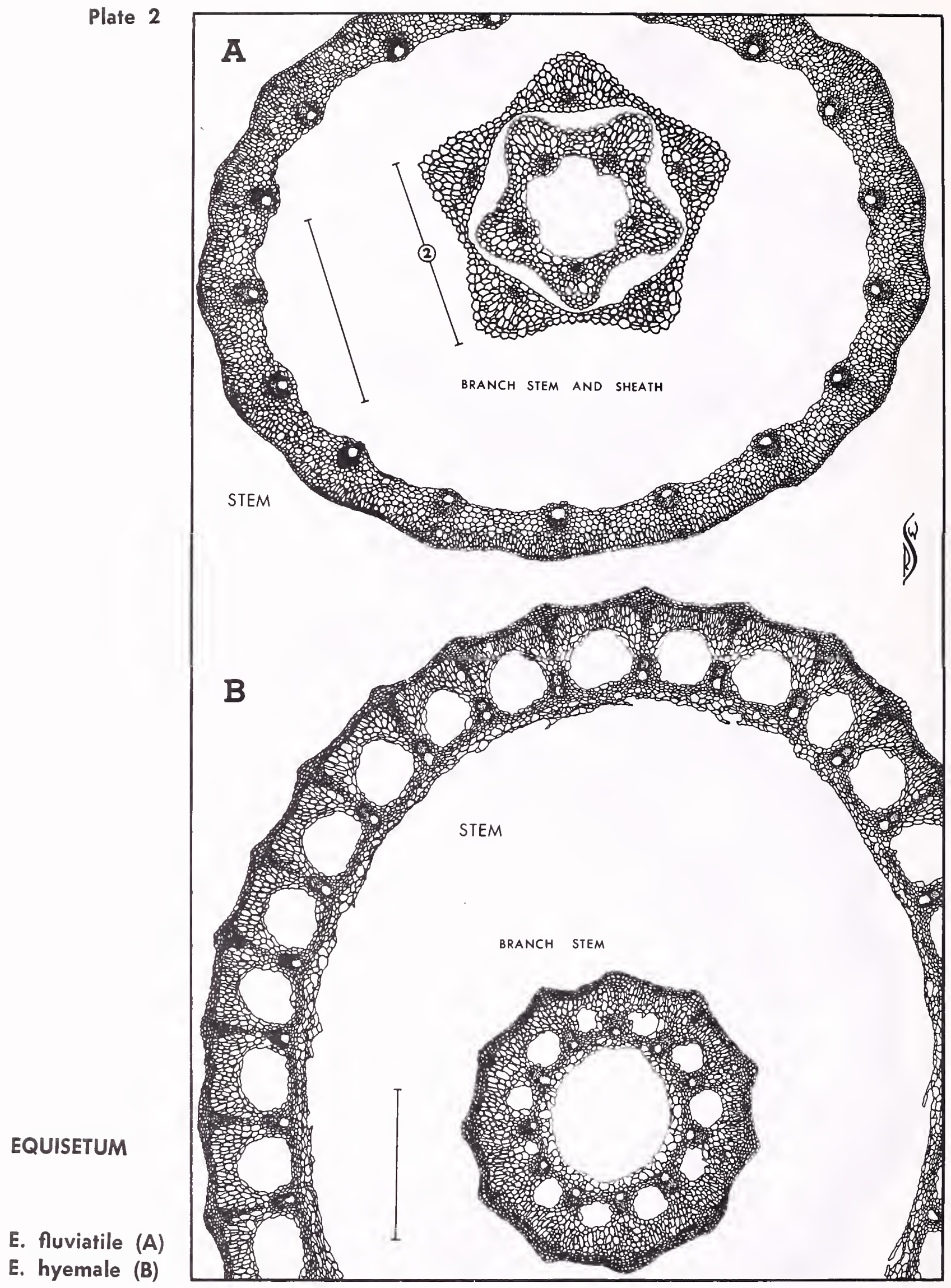




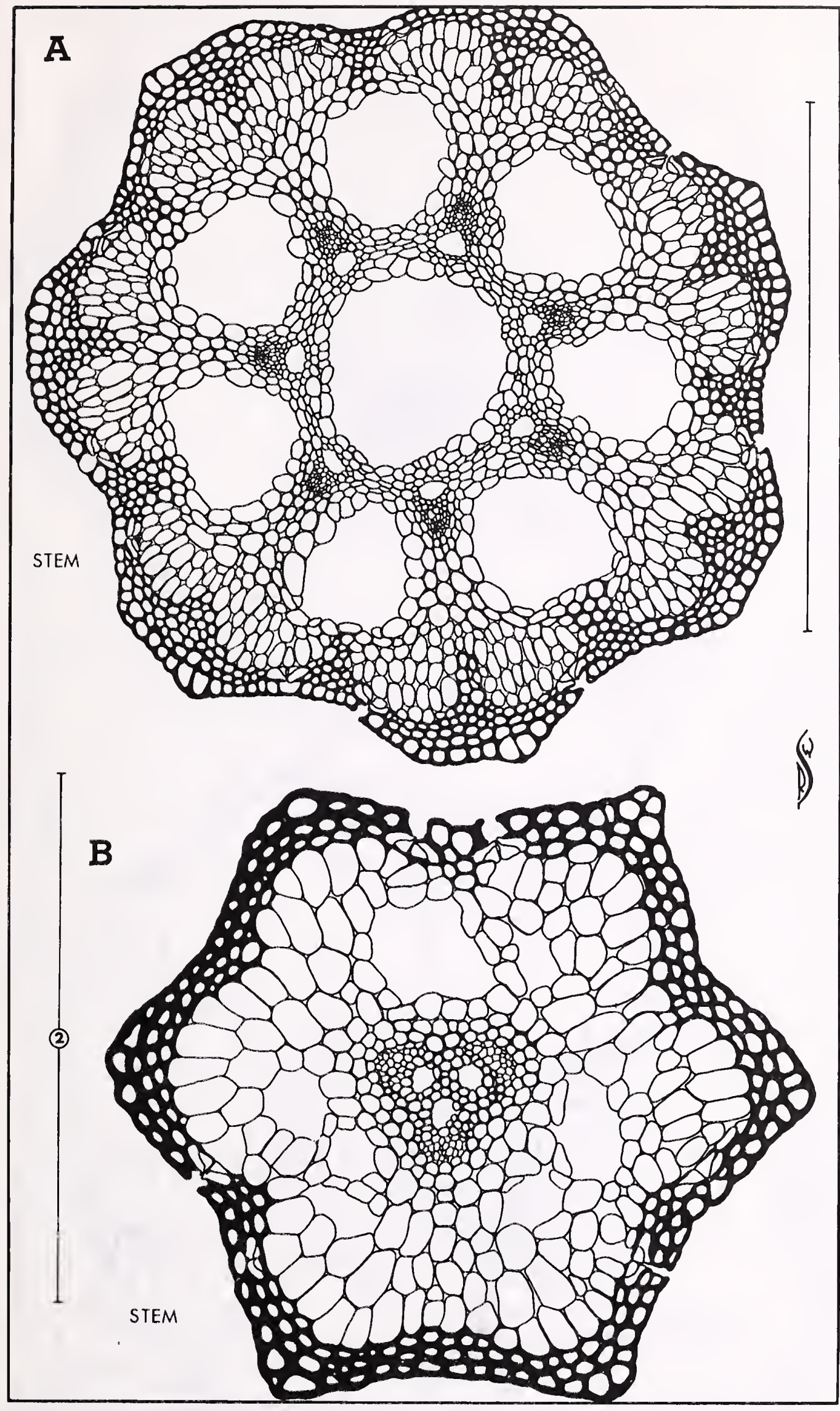

Plate 3

\section{EQUISETUM}

E. variegatum (A)

E. scirpoides (B) 


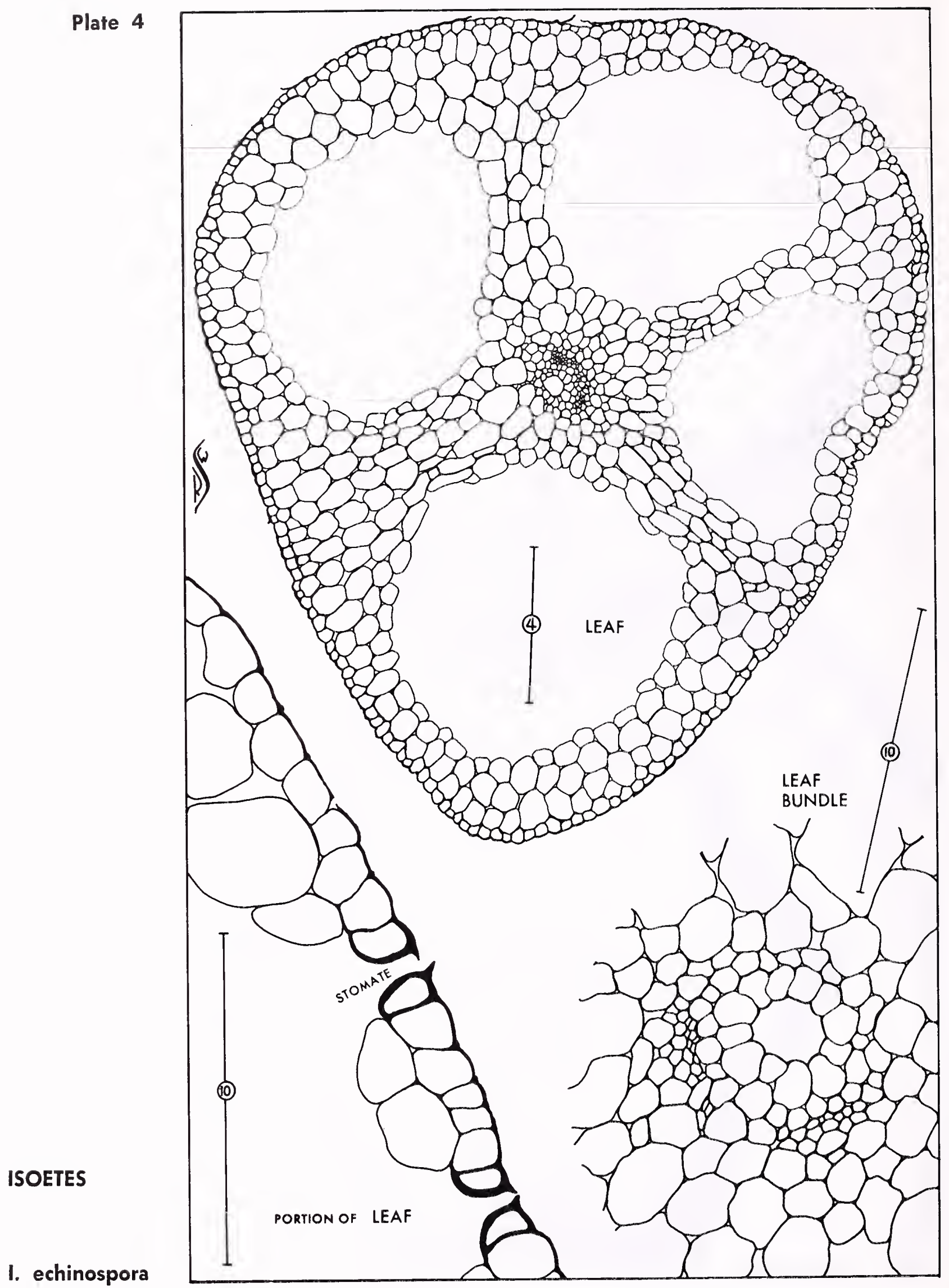




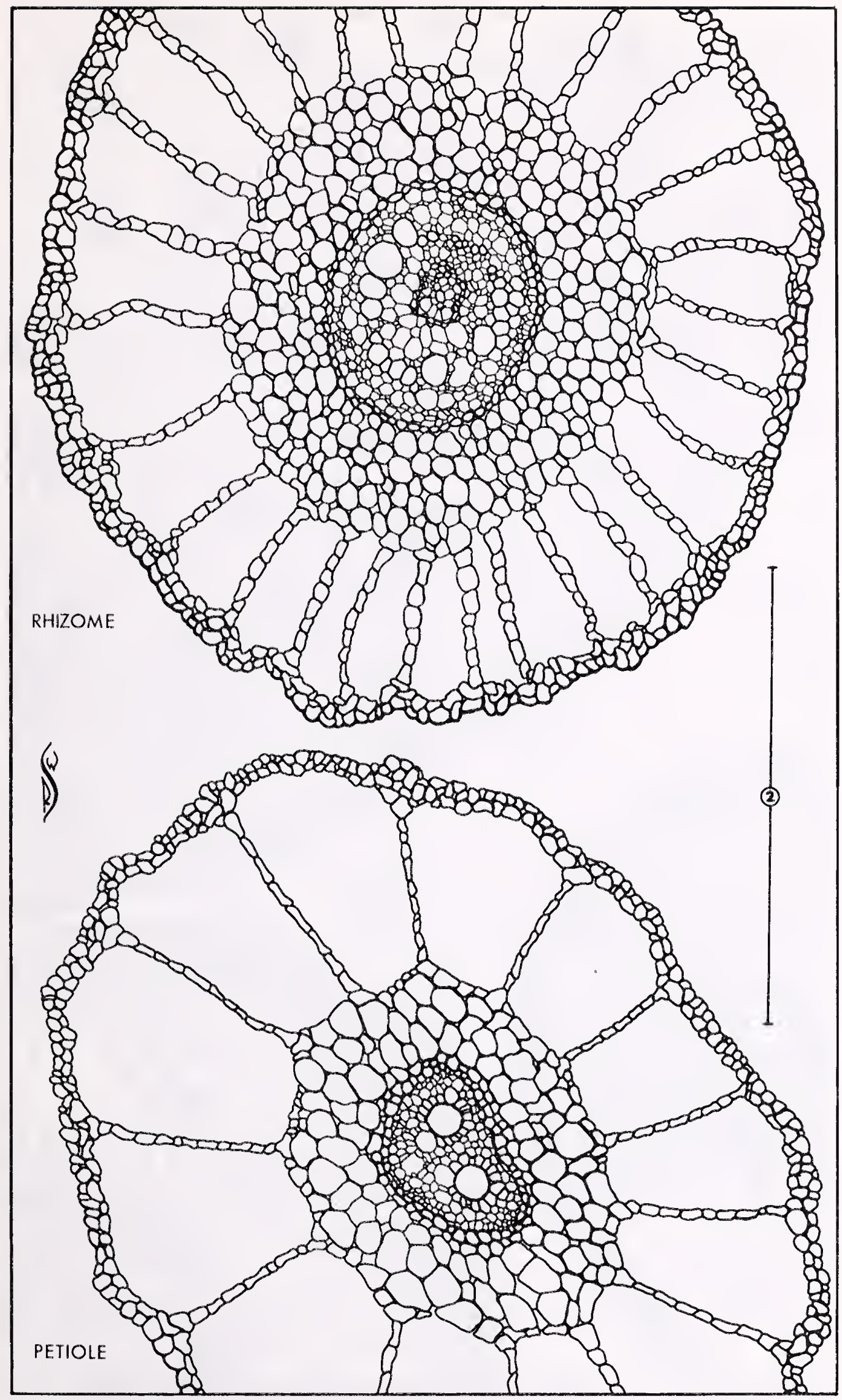

Plate 5

MARSILEA

M. quadrifolia 
Plate 6

SPARGANIUM

S. americanum

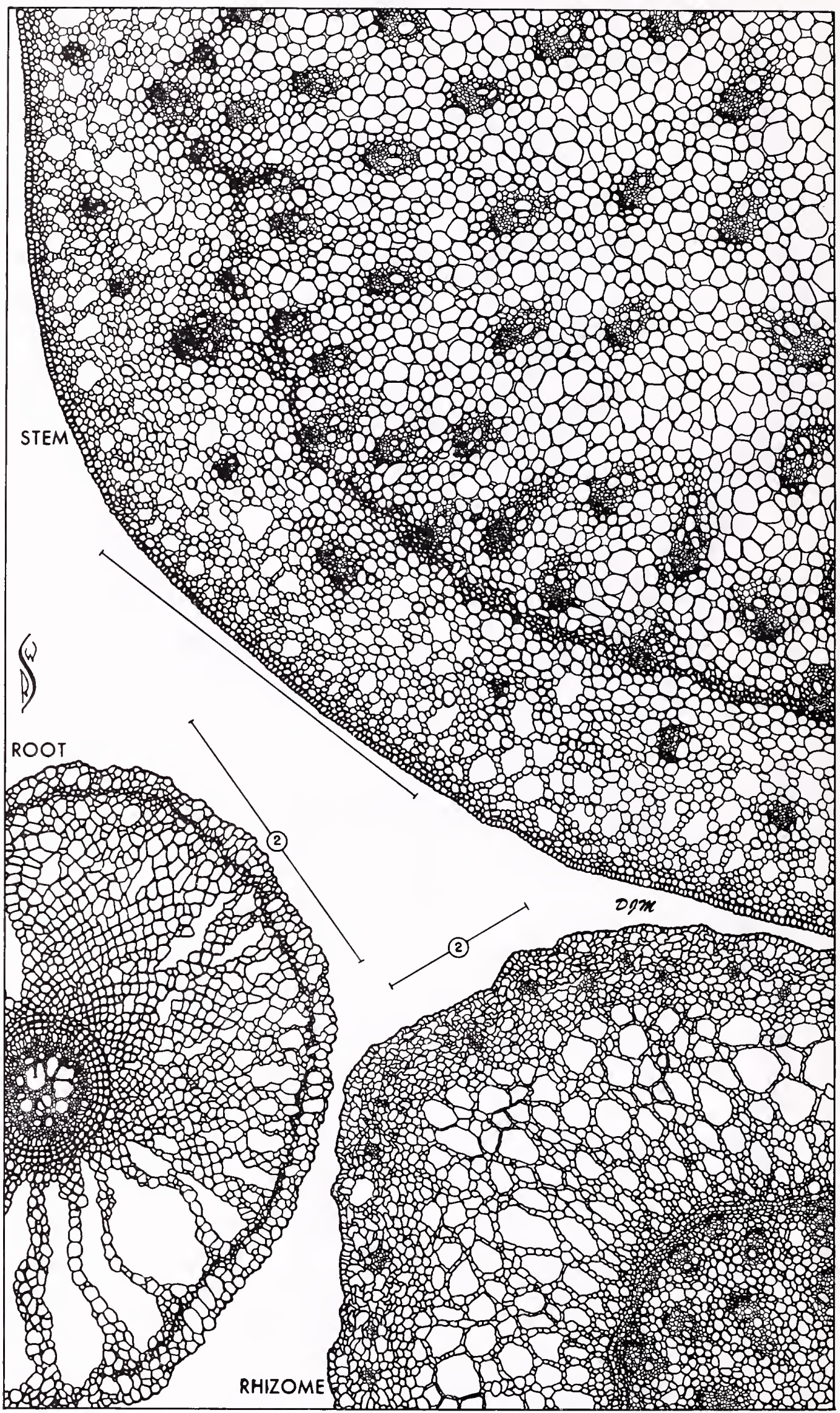




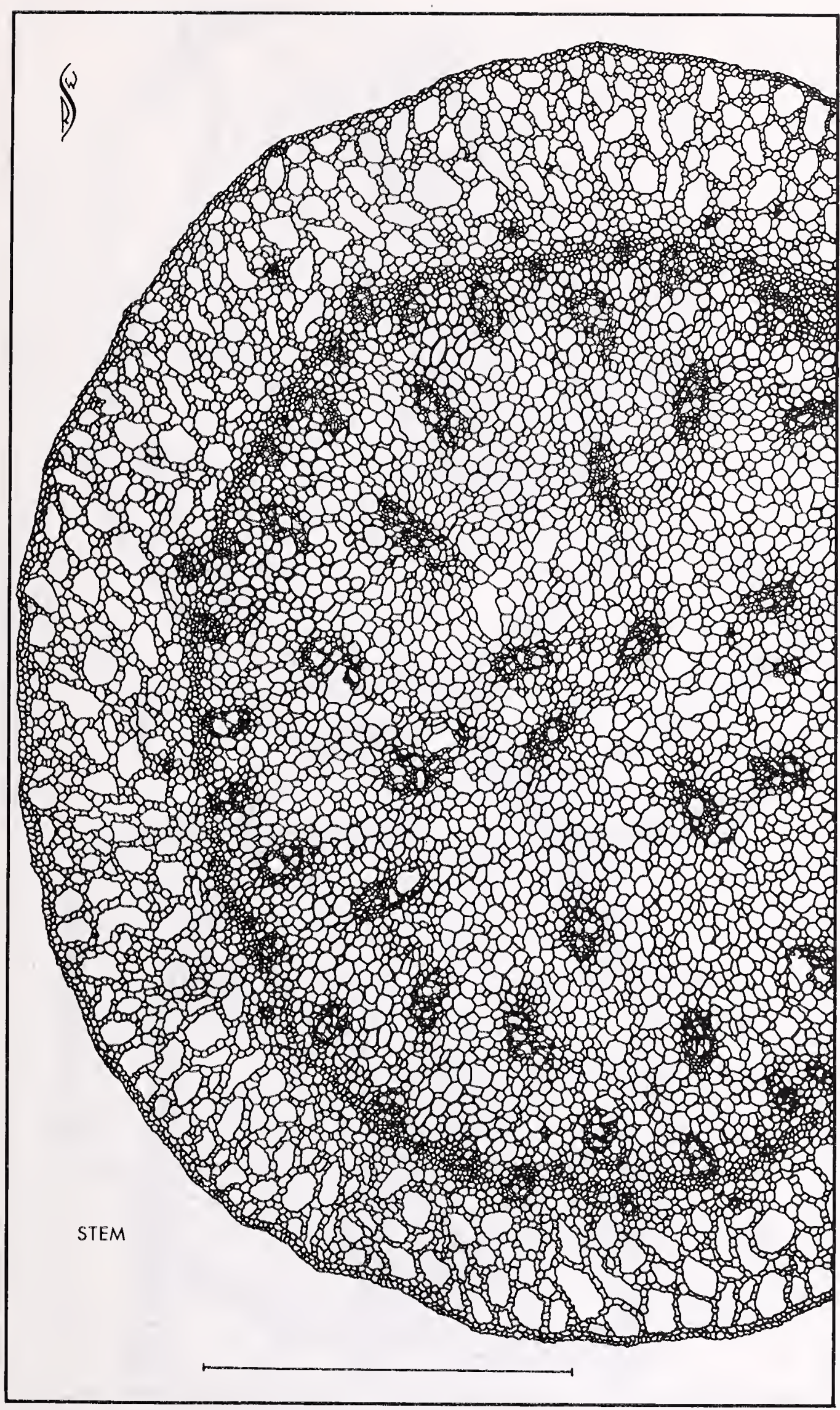

Plate 7

SPARGANIUM

S. angustifolium 


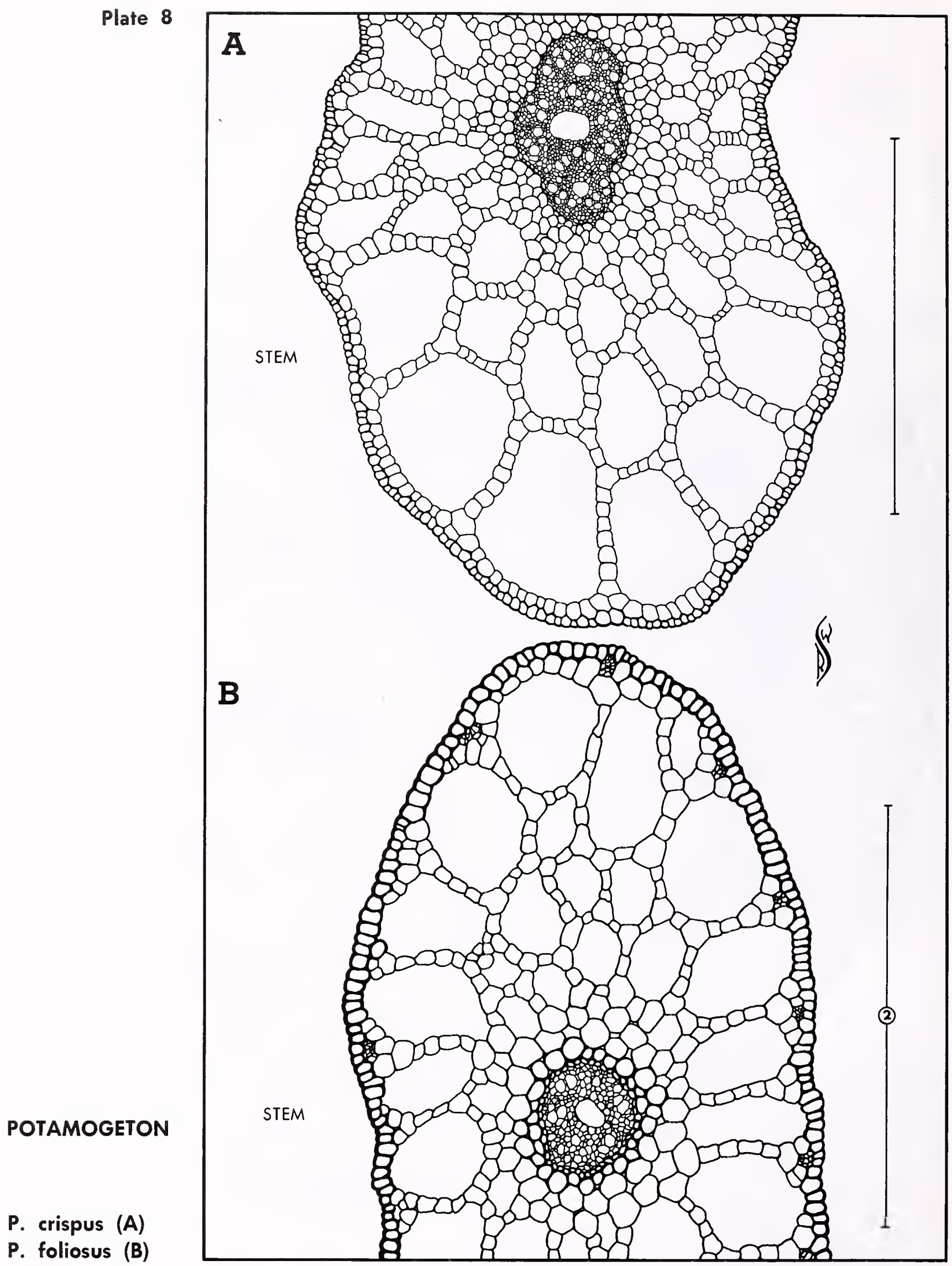




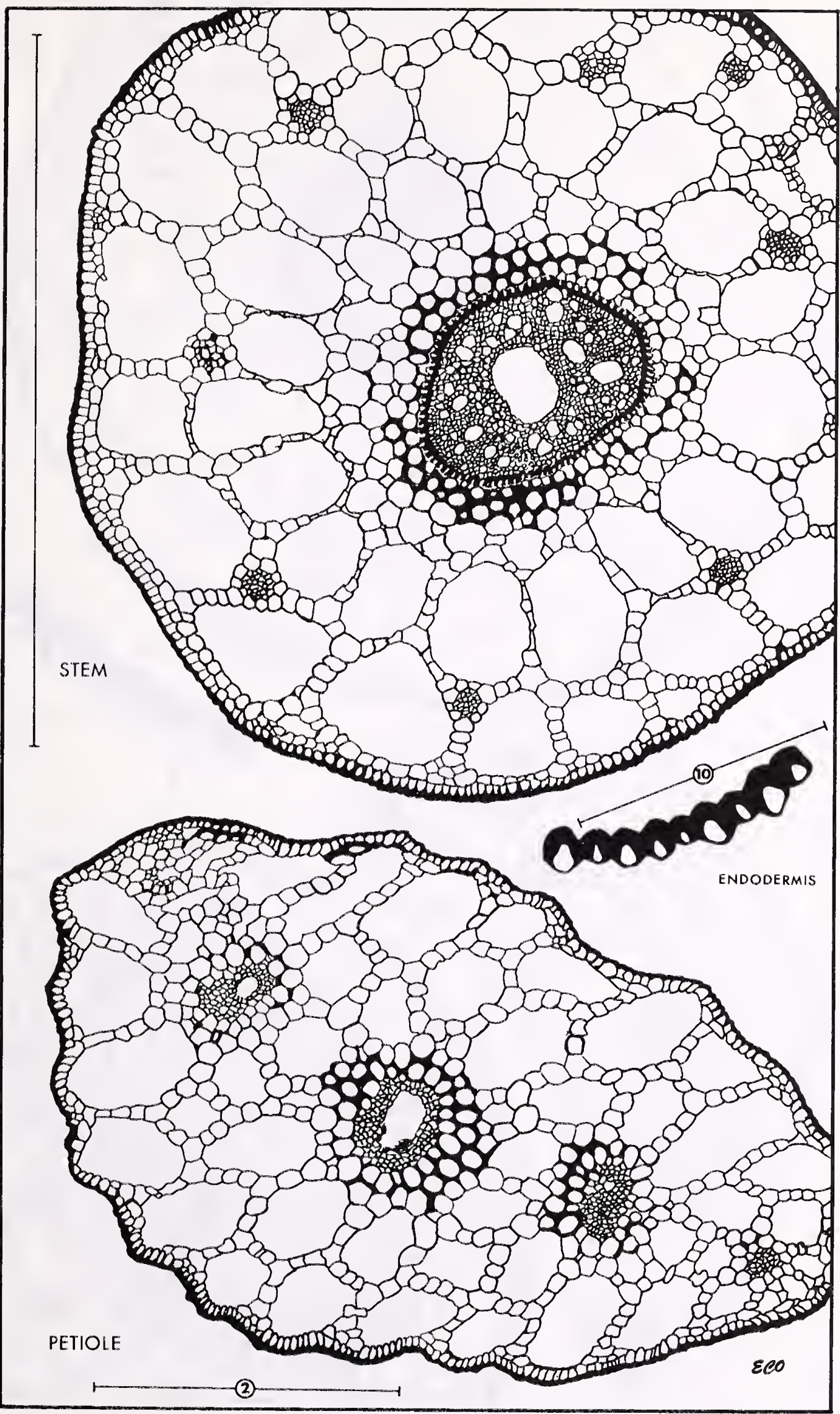

Plate 9

POTAMOGETON

P. gramineus 
Plate 10

POTAMOGETON

P. natans

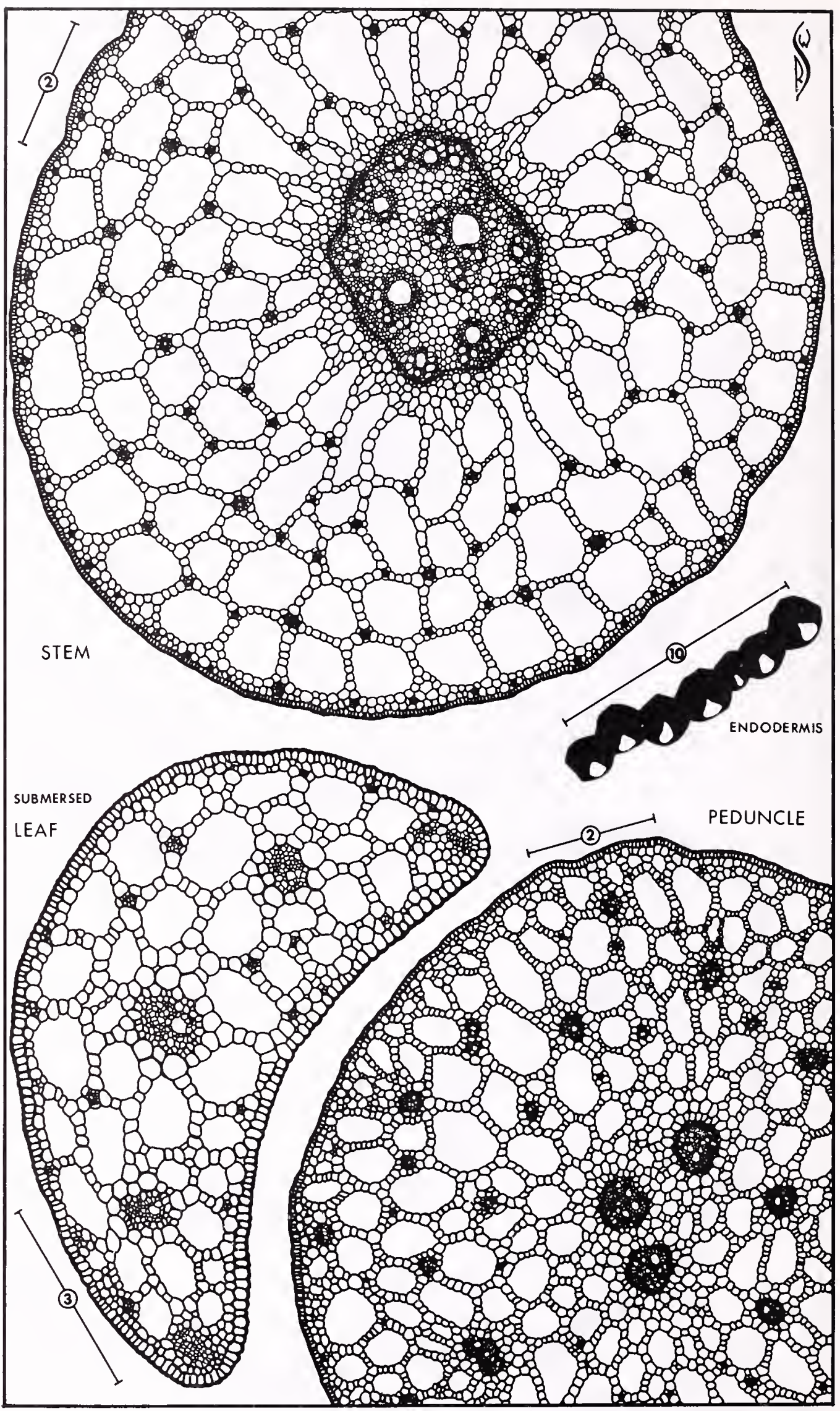




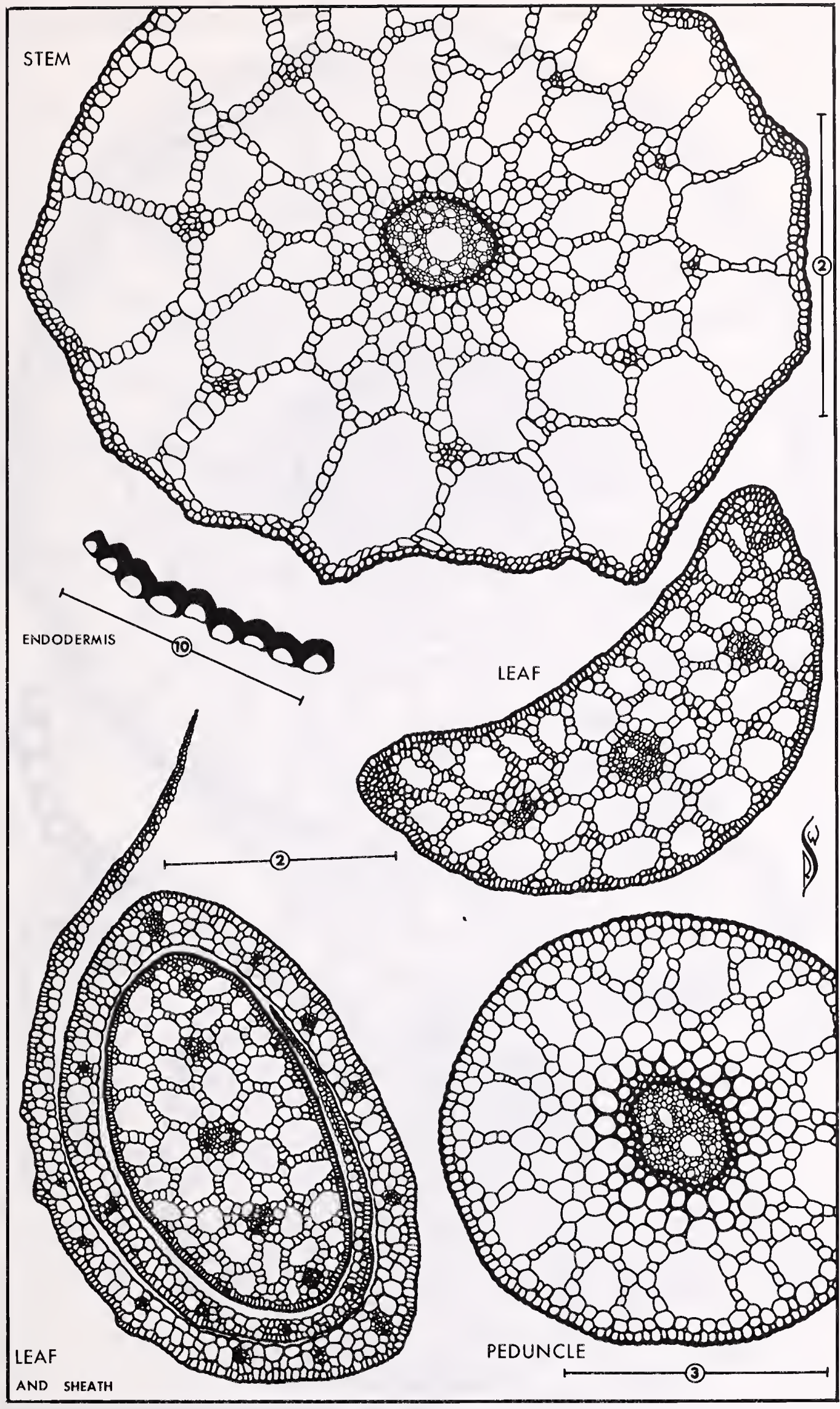

Plate 11

POTAMOGETON

P. pectinatus 
Plate 12

POTAMOGETON

P. perfoliatus

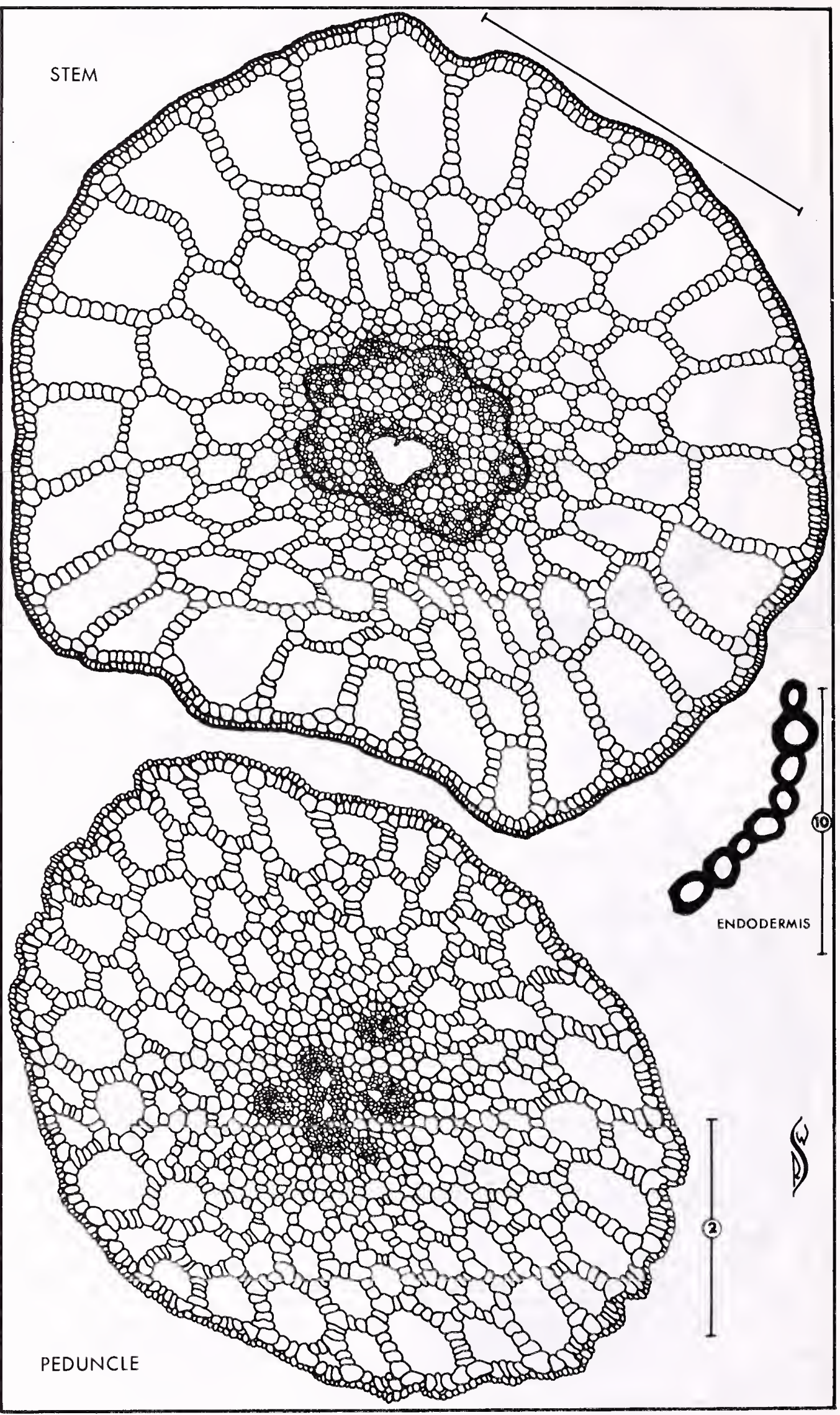




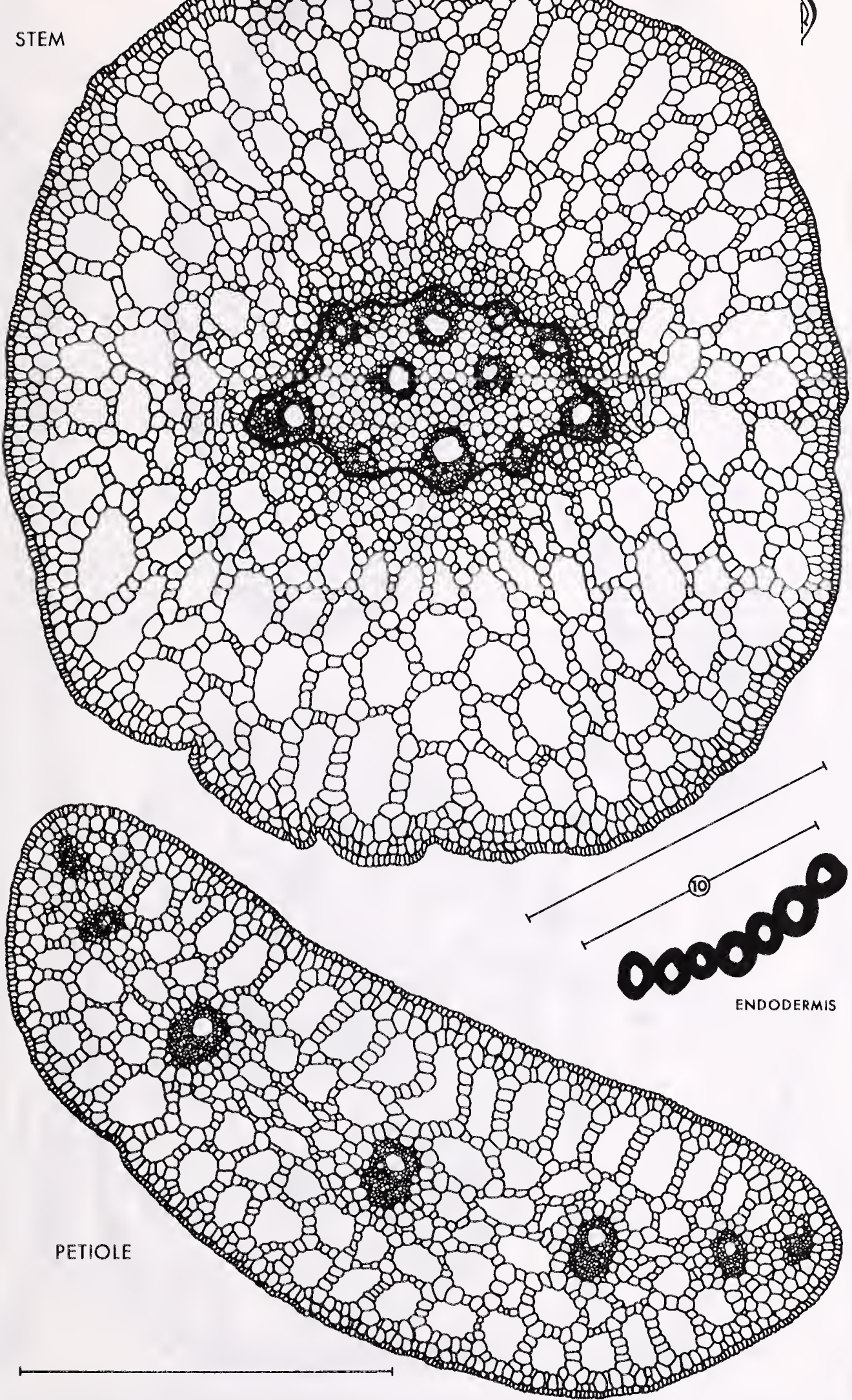

POTAMOGETON

P. pulcher 


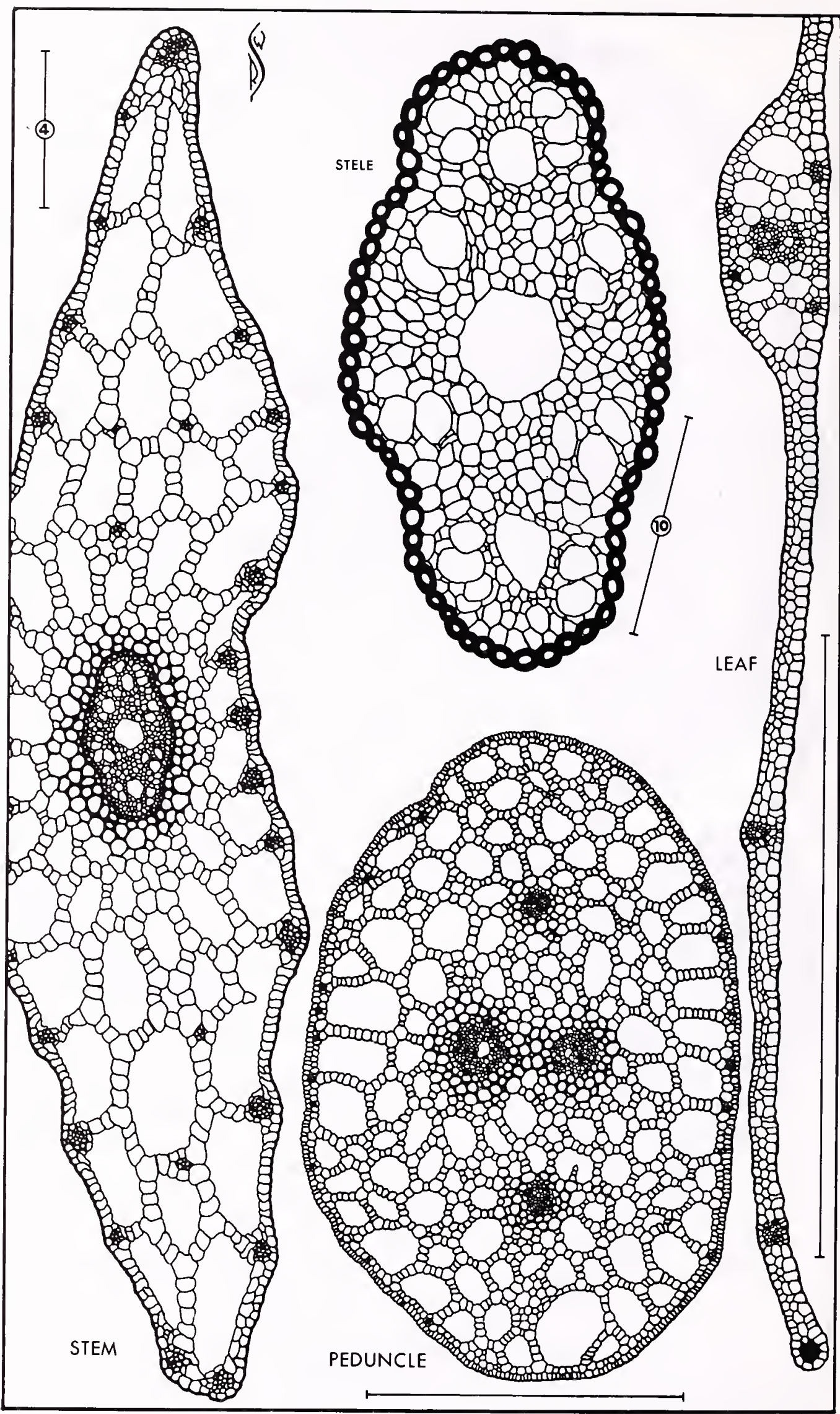




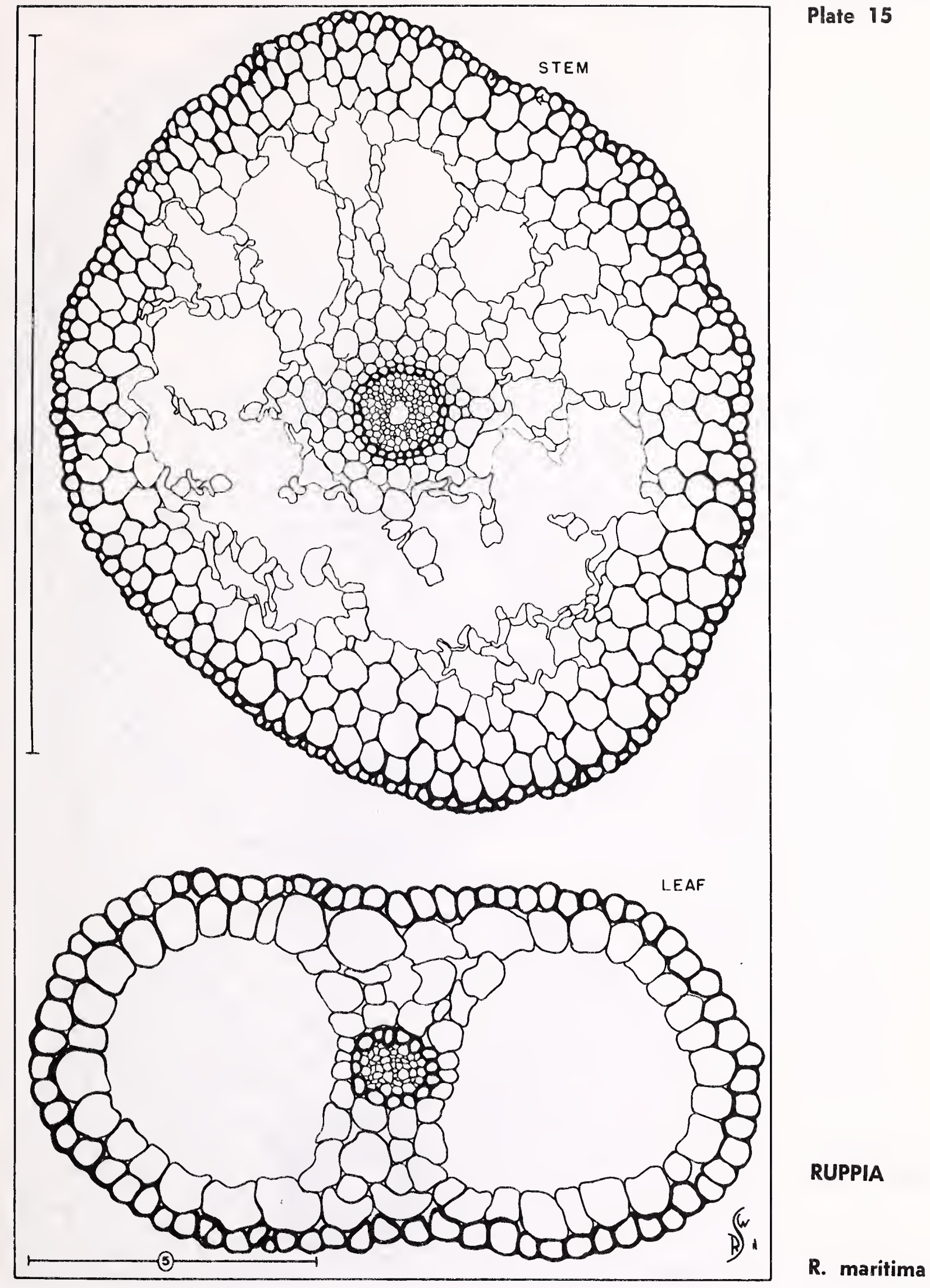




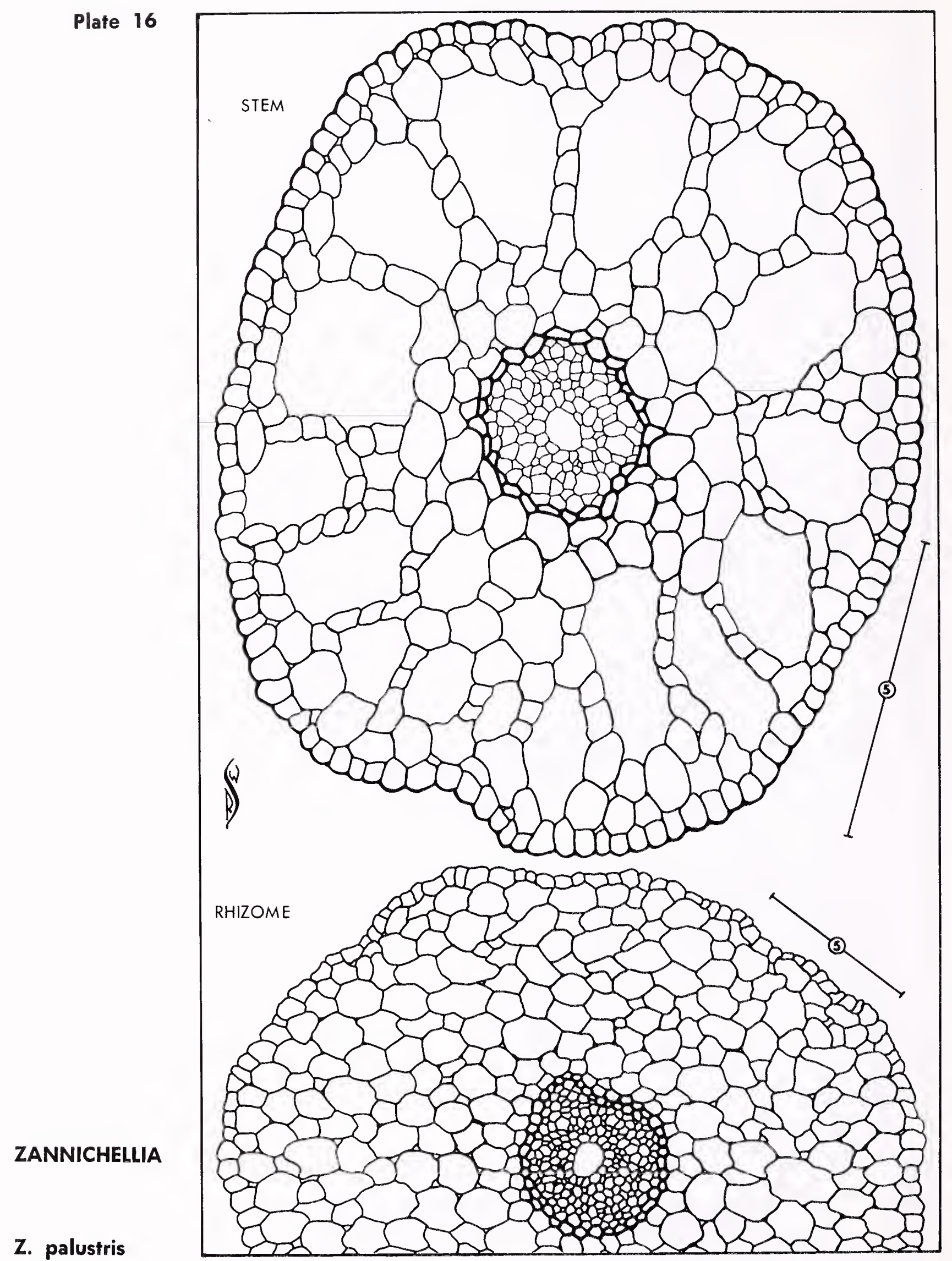




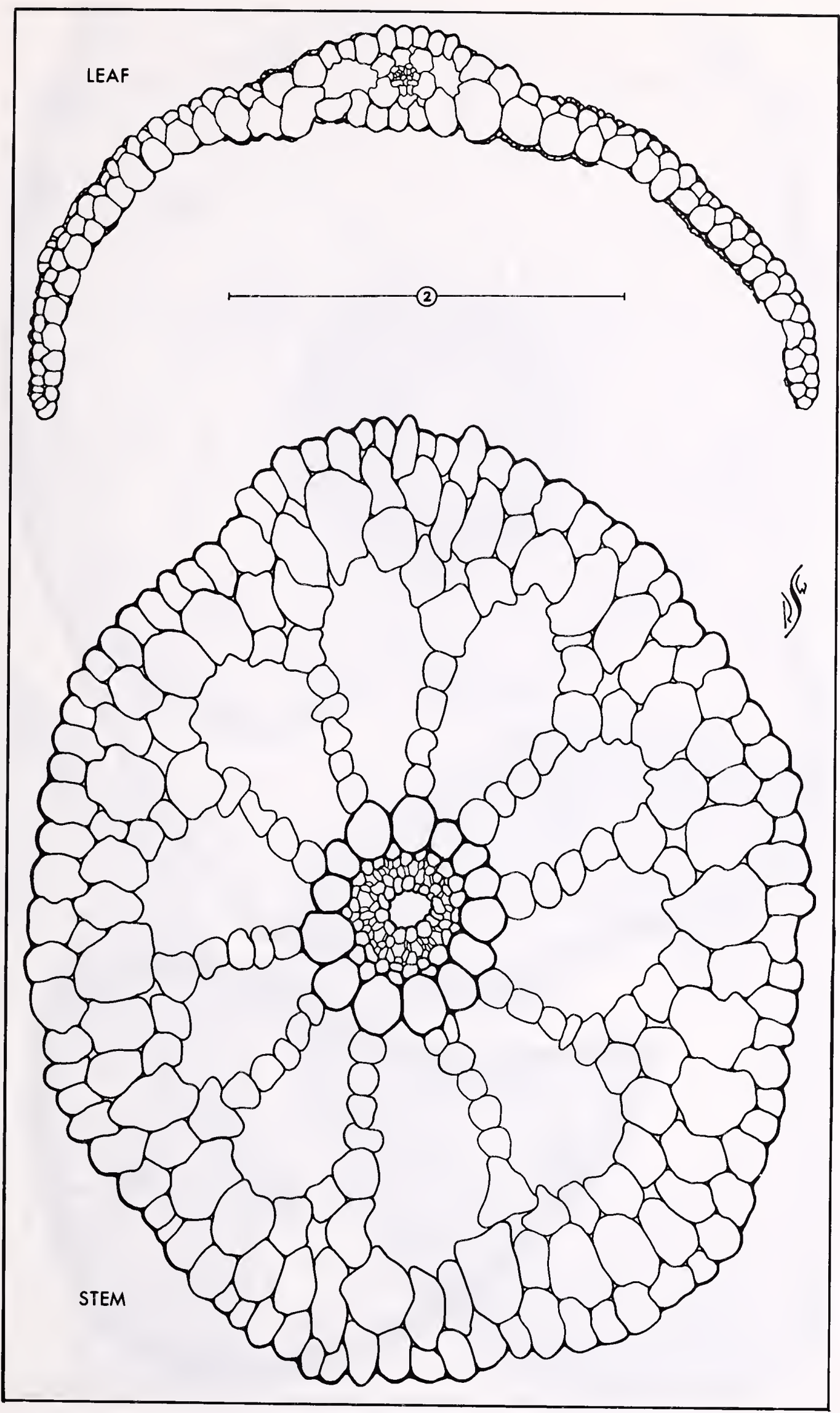

Plate 17

NAJAS

N. flexilis 


\section{S. palustris}

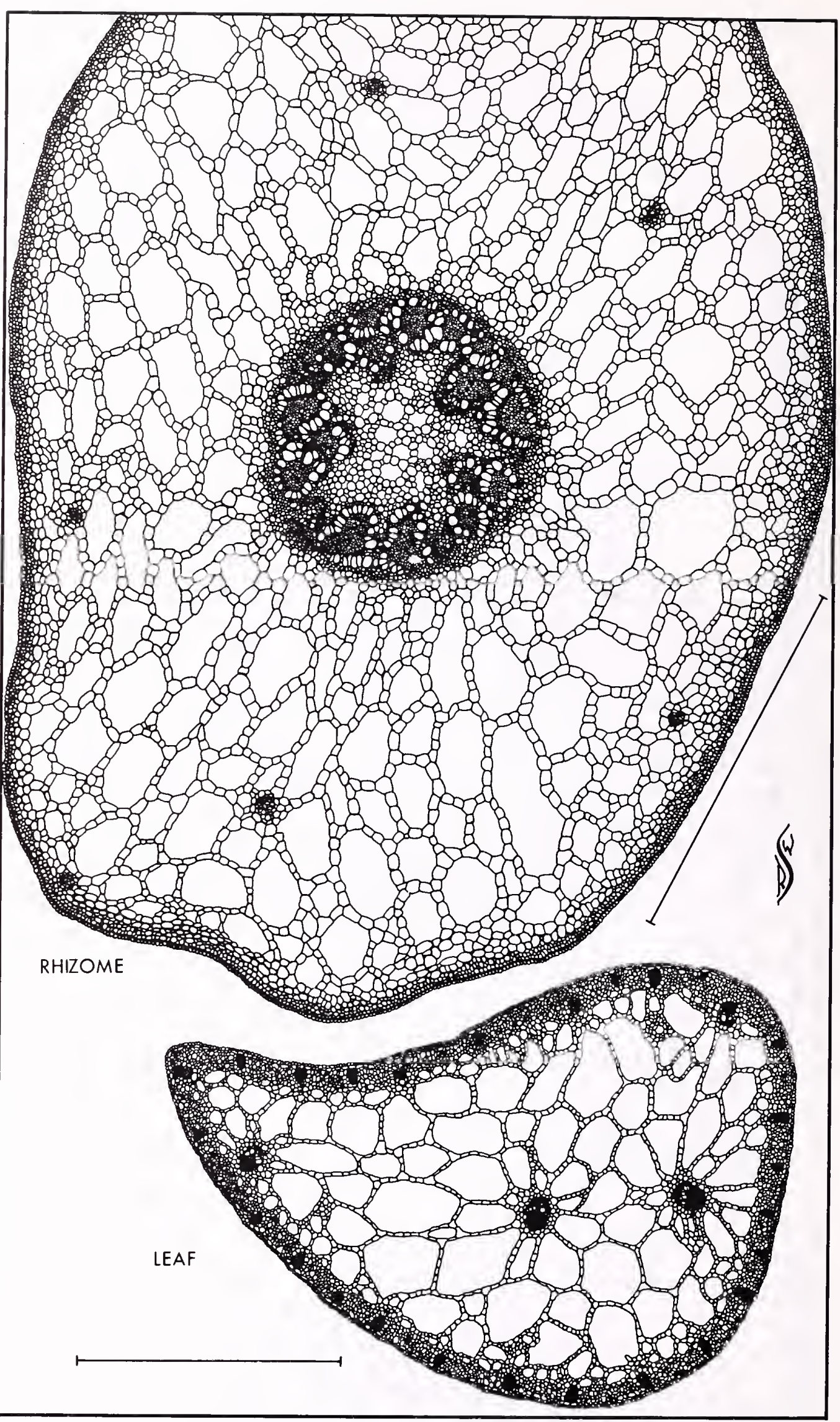




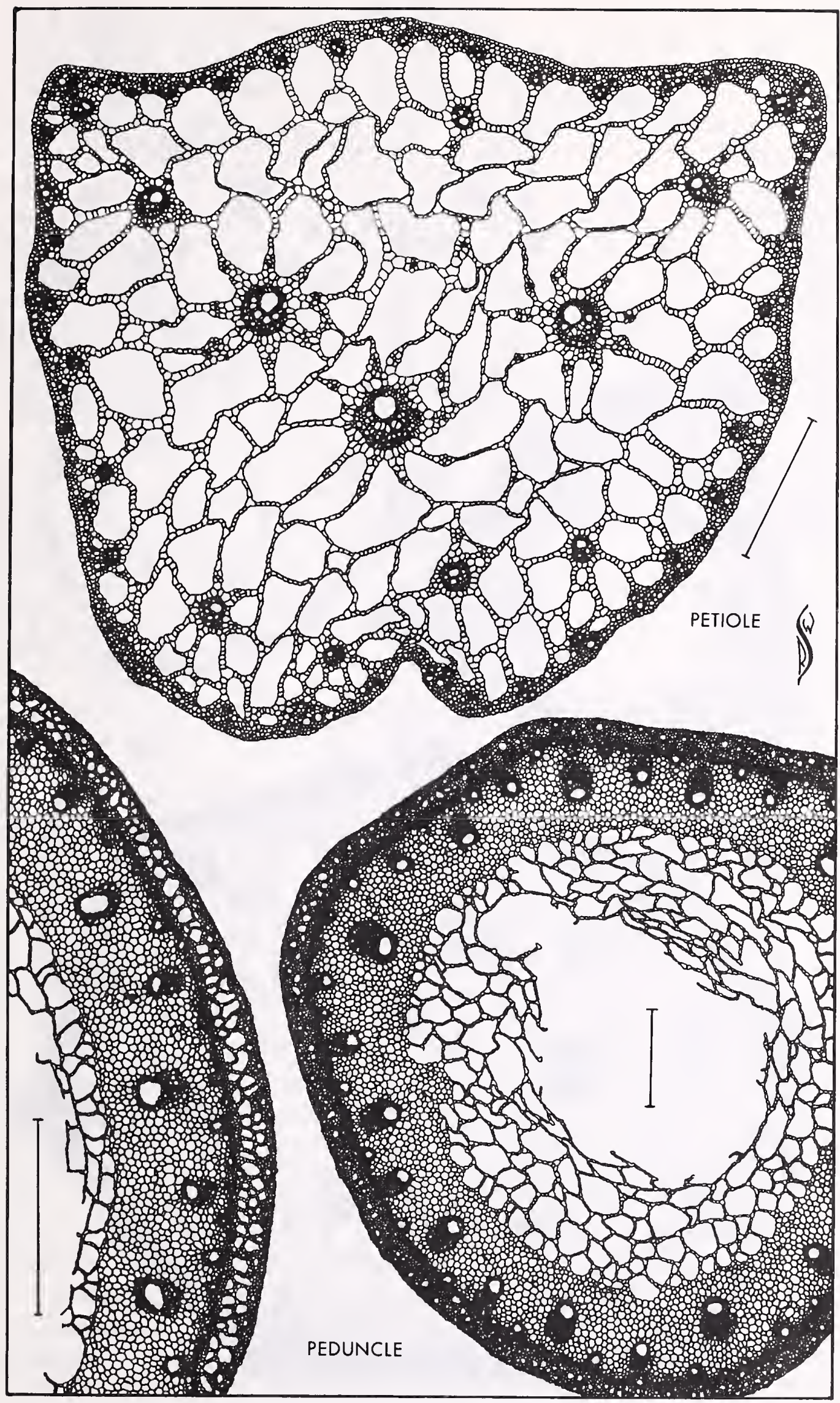

Plate 19

\section{ALISMA}

A. plantago-aquatica 


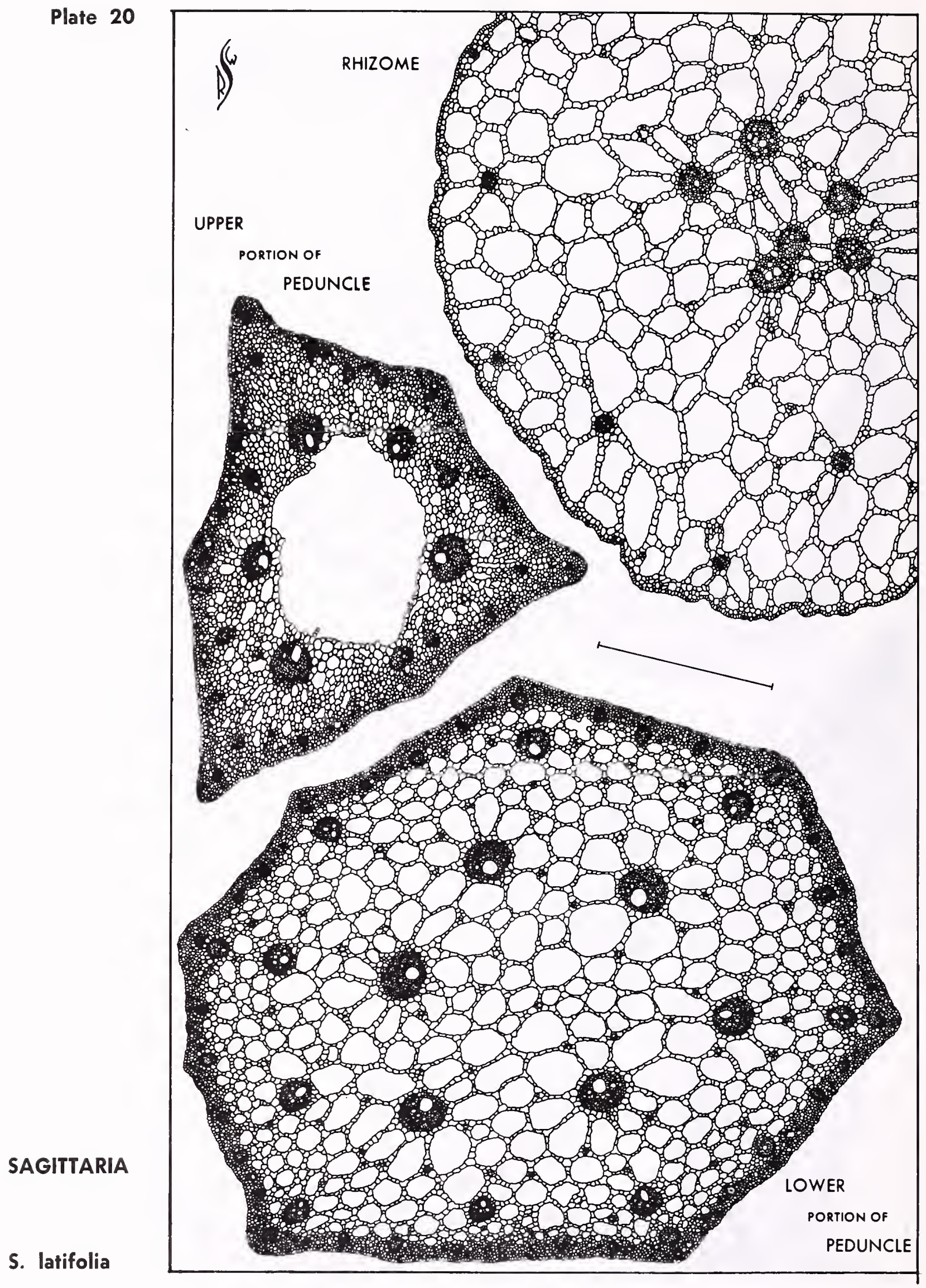




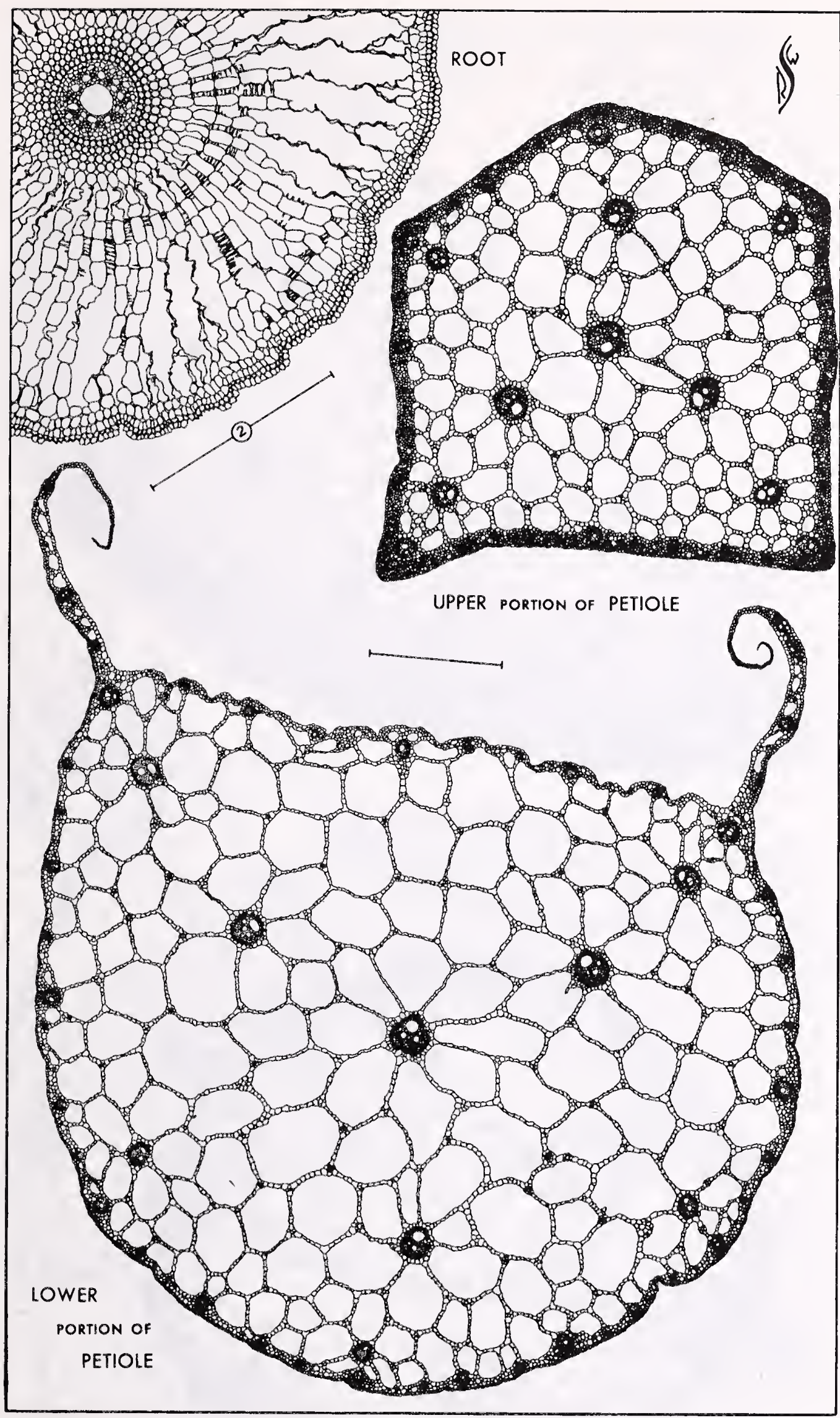

Plate 21

SAGITTARIA

S. latifolia 


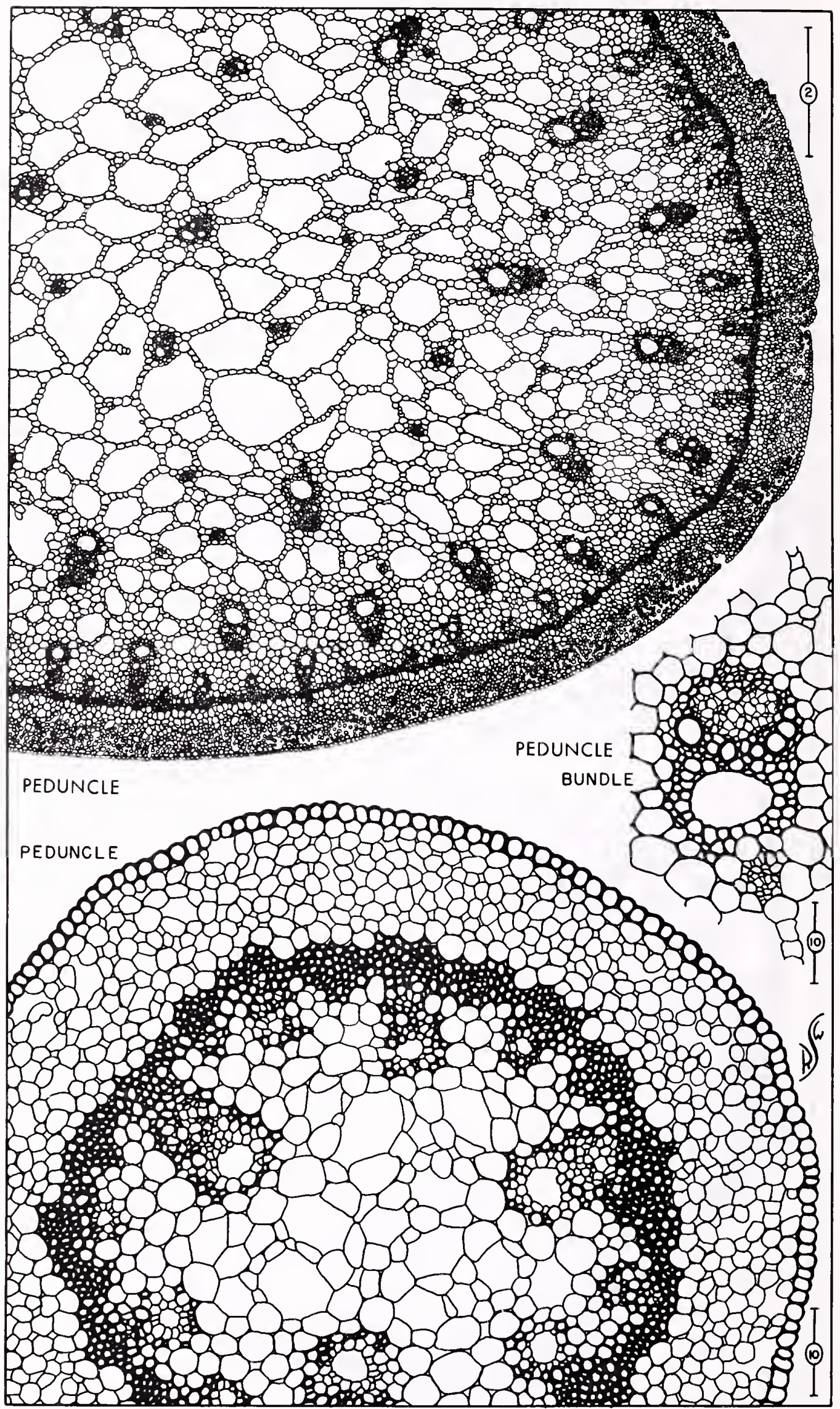




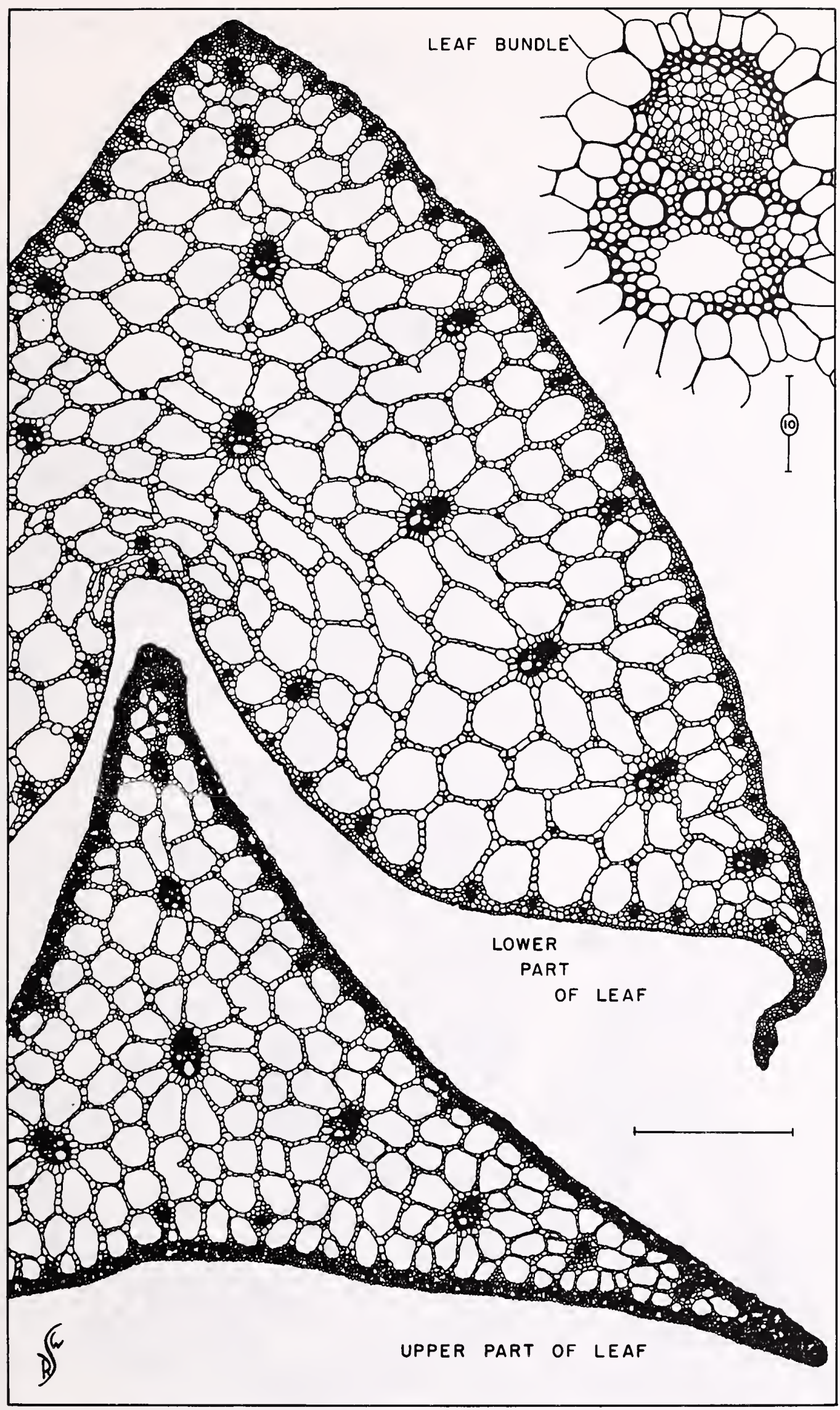

Plate 23

\section{BUTOMUS}

B. umbellatus 


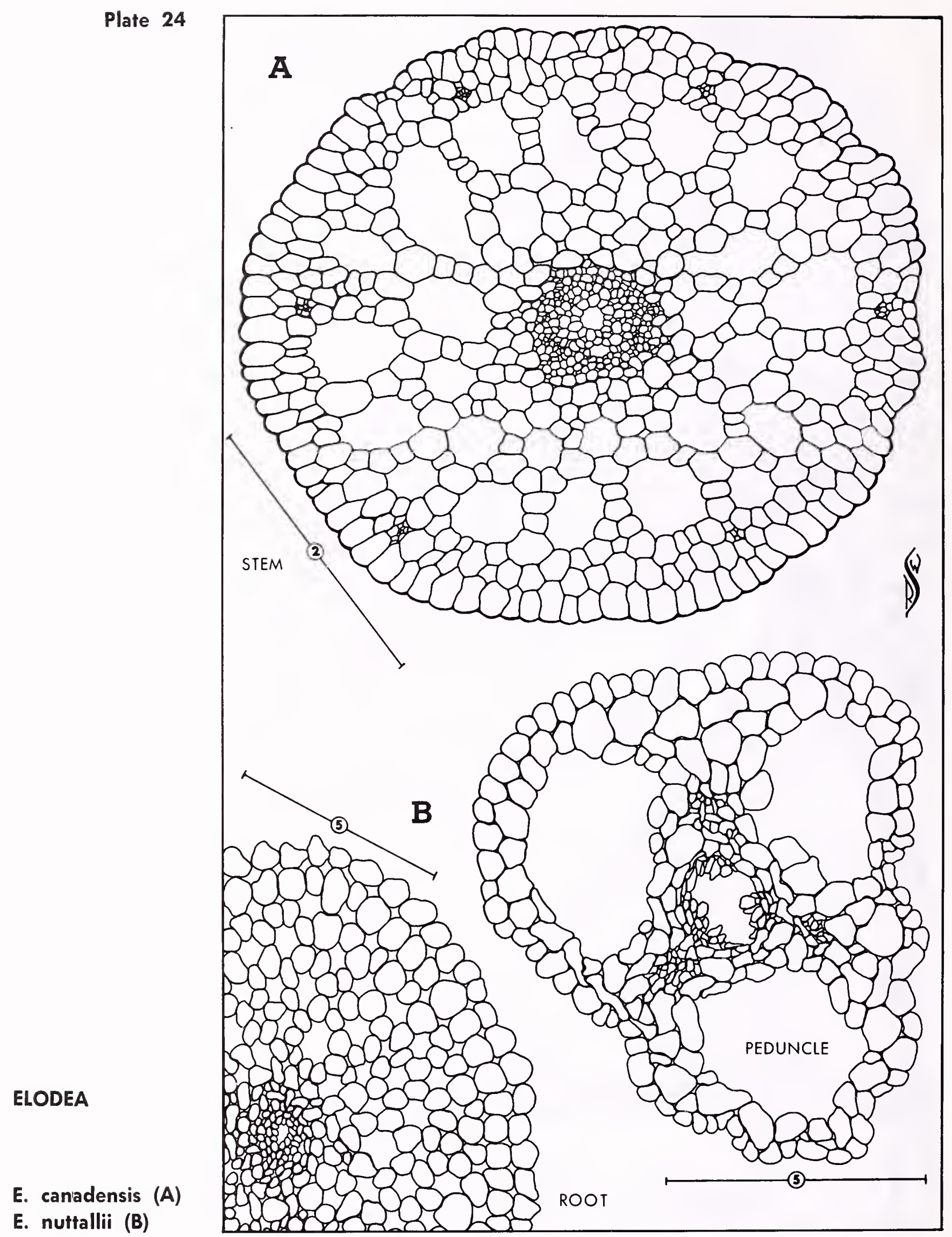




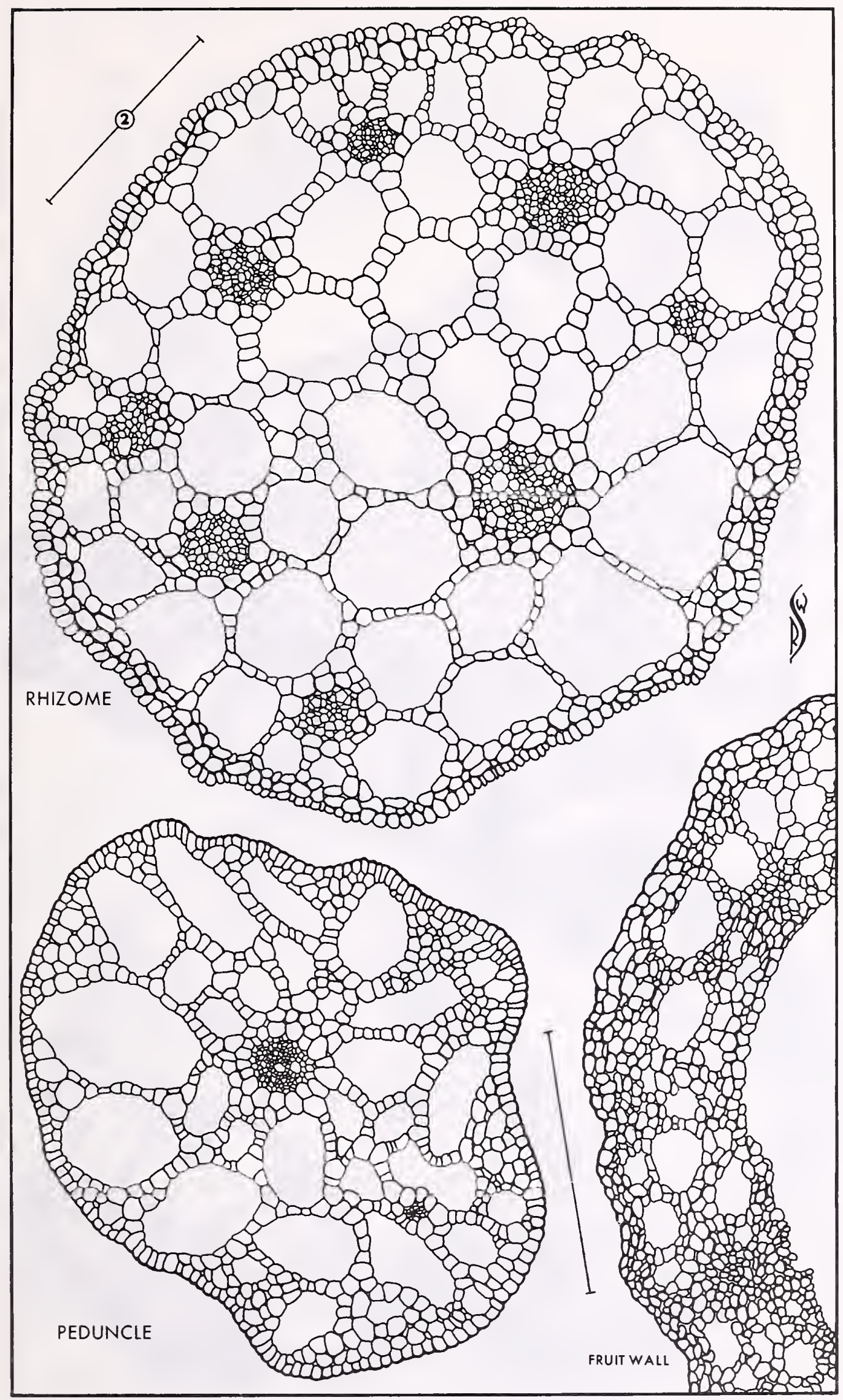

Plate 25

VALLISNERIA

V. americana 
CAREX

FUIRENA

C. comosa (A)

F. squarosa (B)

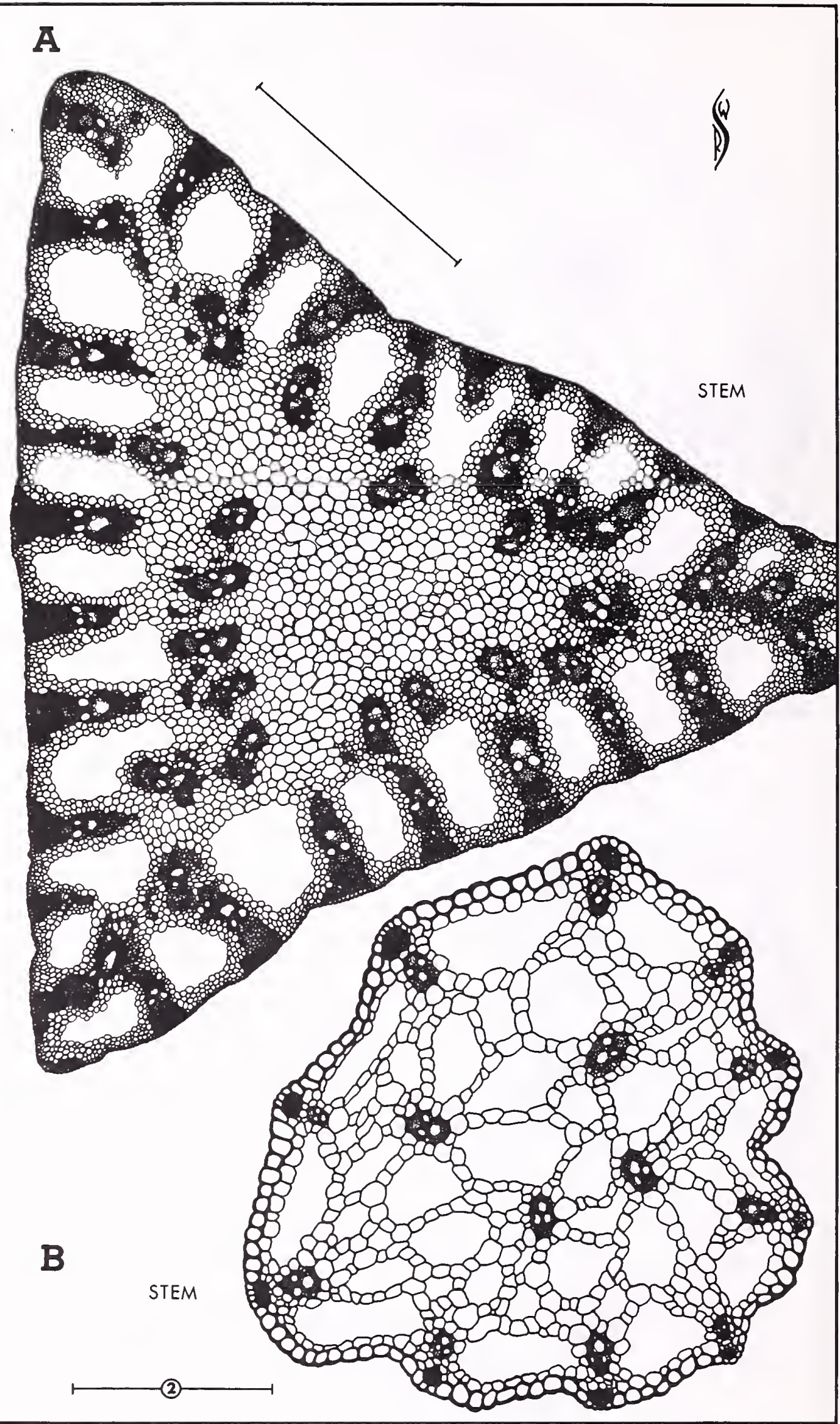




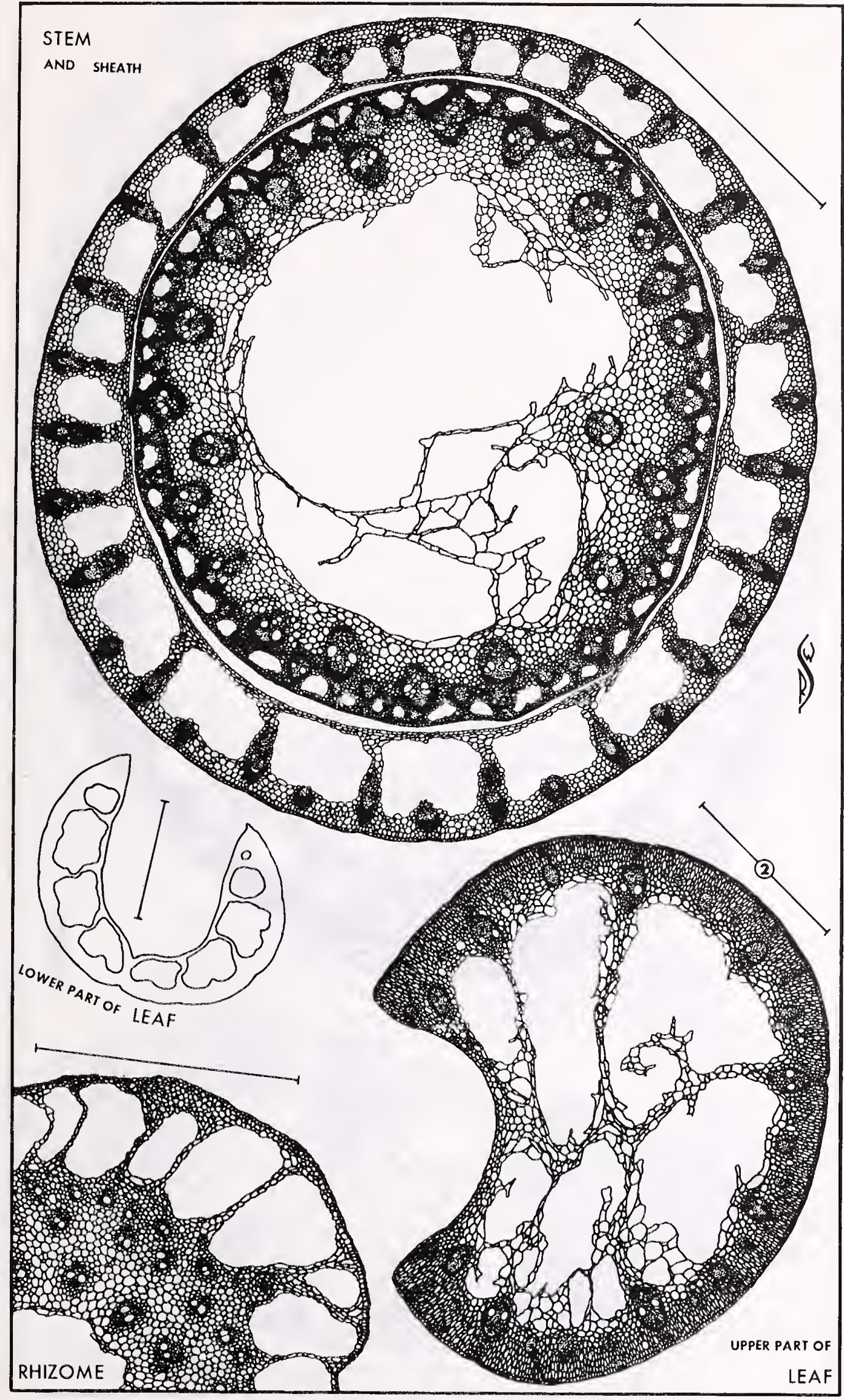

Plate 27

CLADIUM

C. mariscoides 


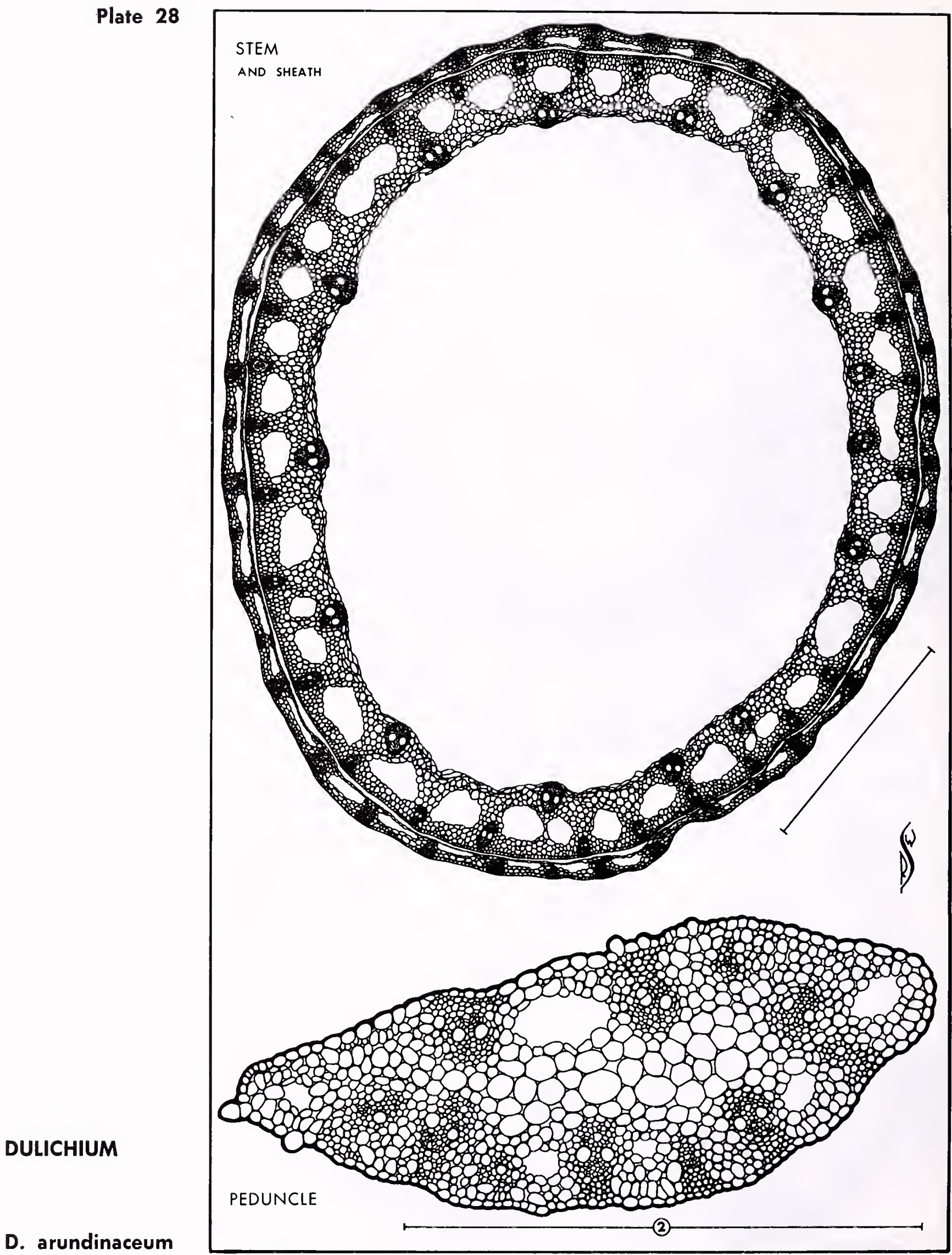




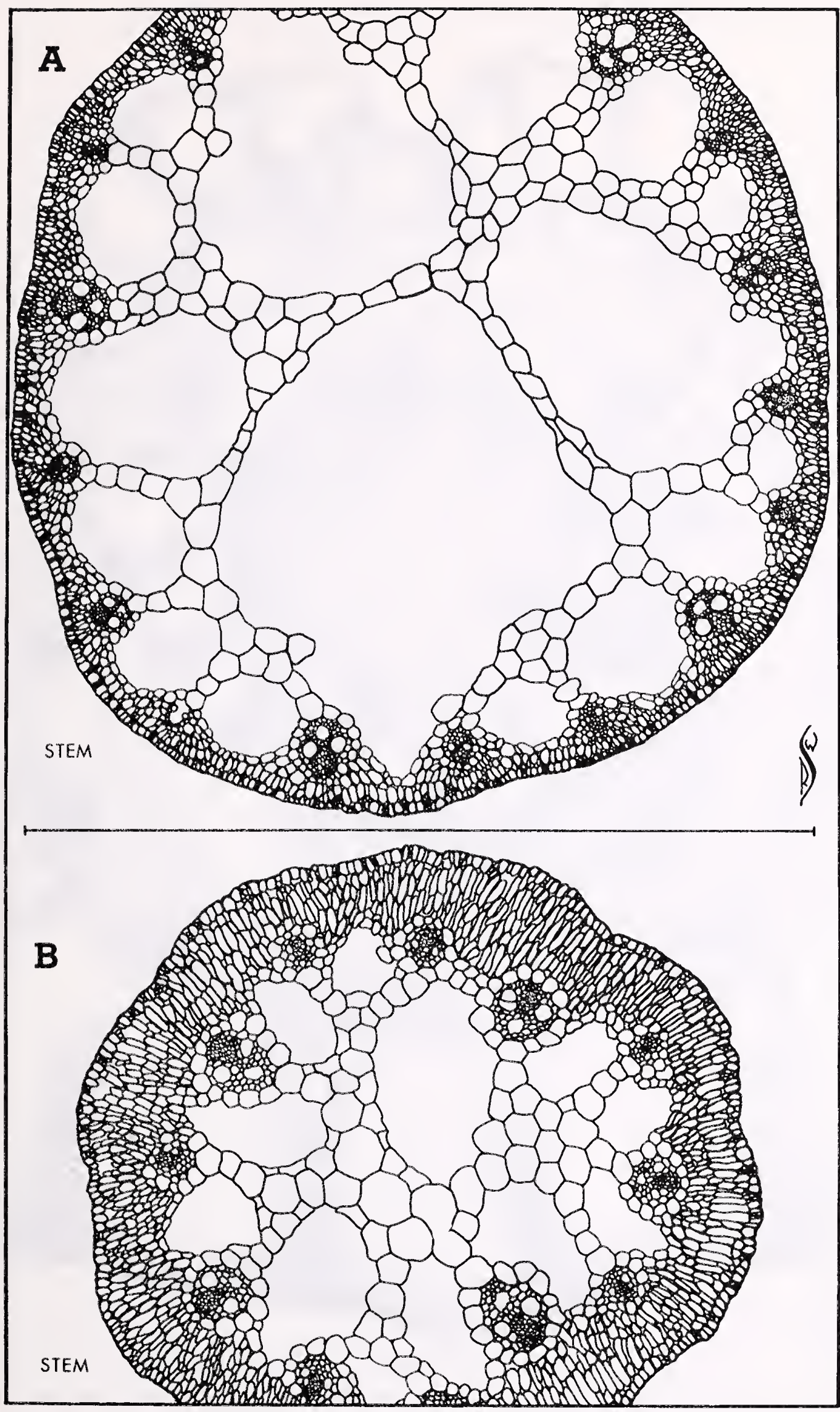

Plate 29

ELEOCHARIS

E. obtusa (A)

E. palustris (B) 


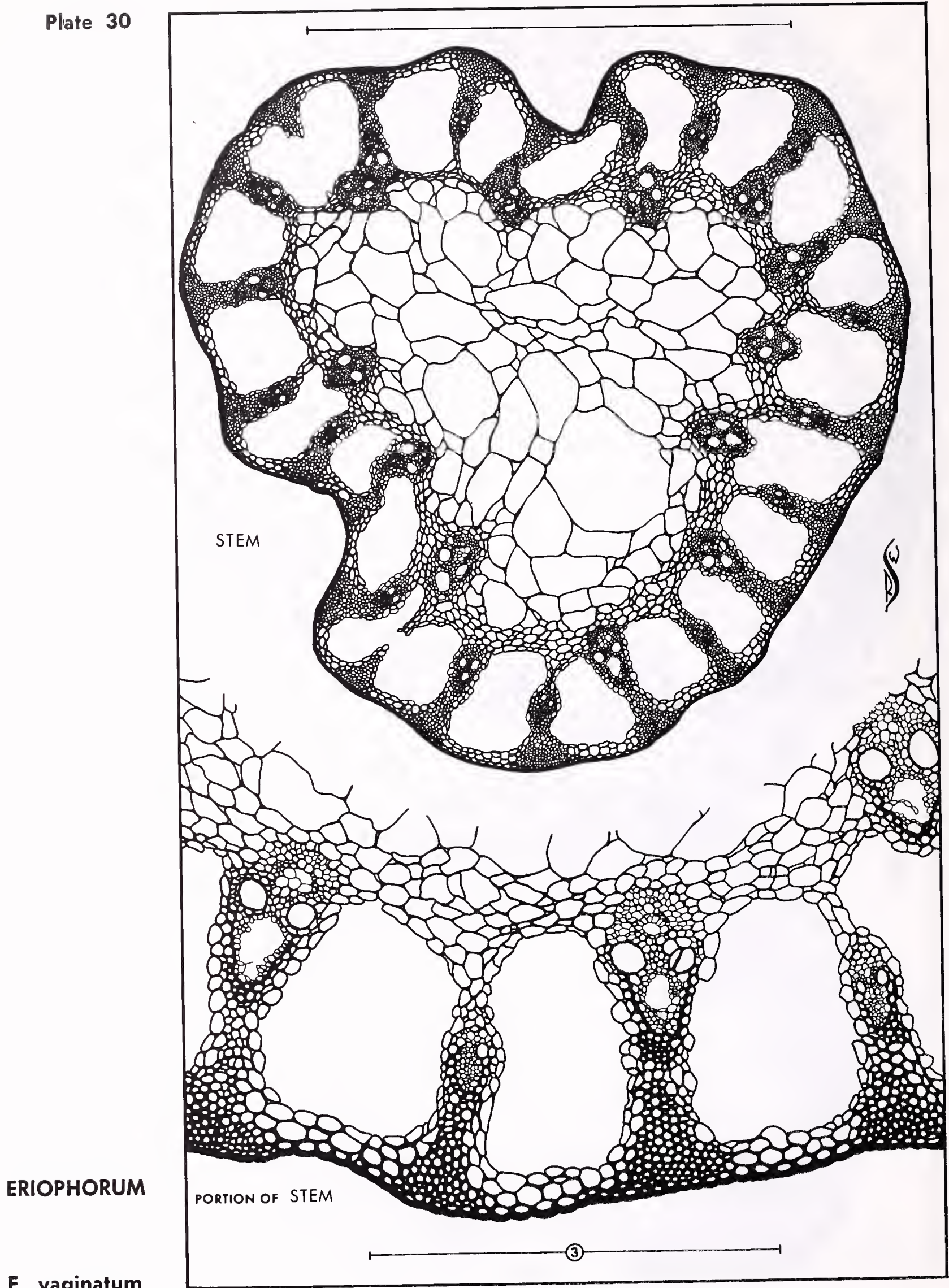



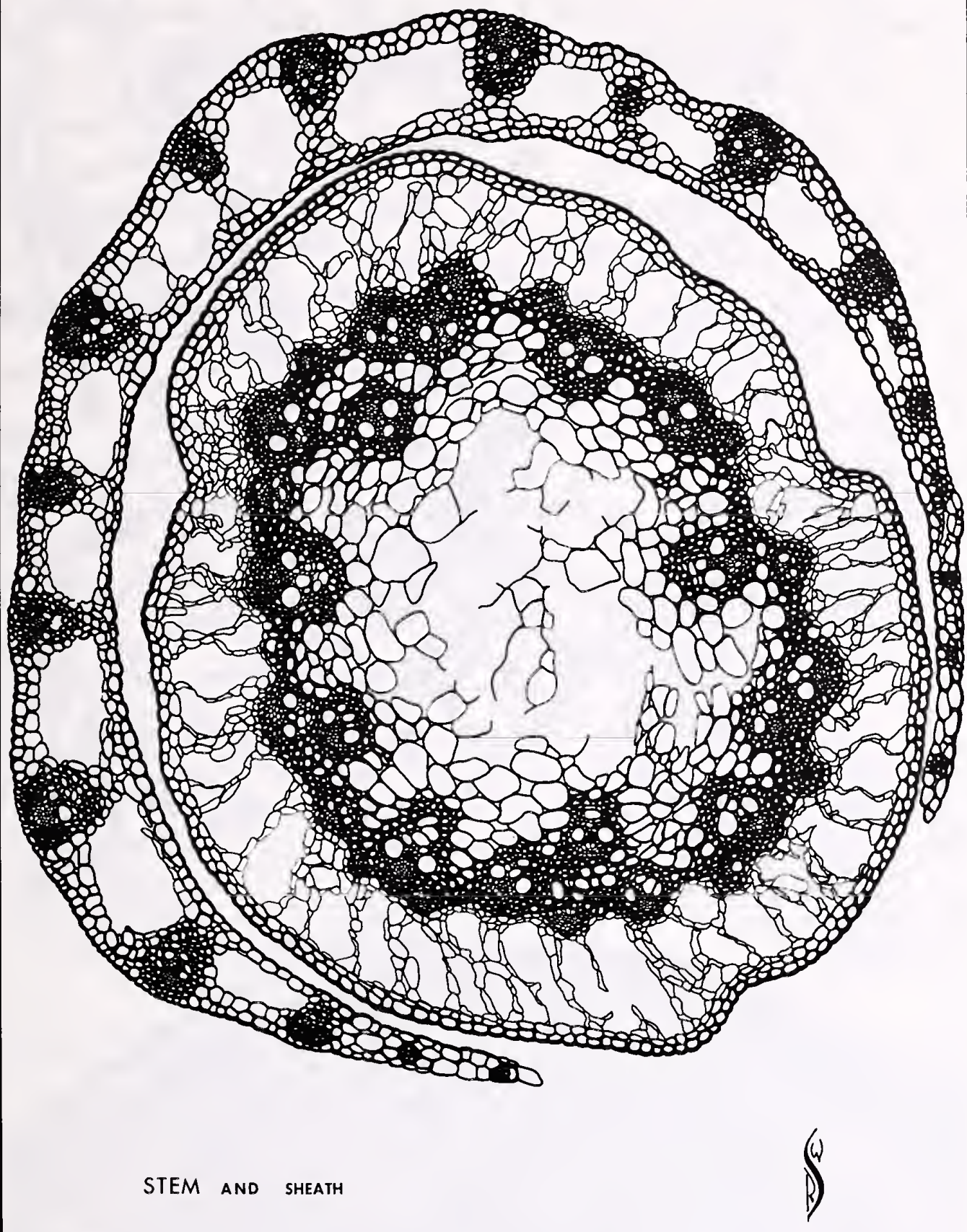

RHYNCHOSPORA

R. alba 
Plate 32

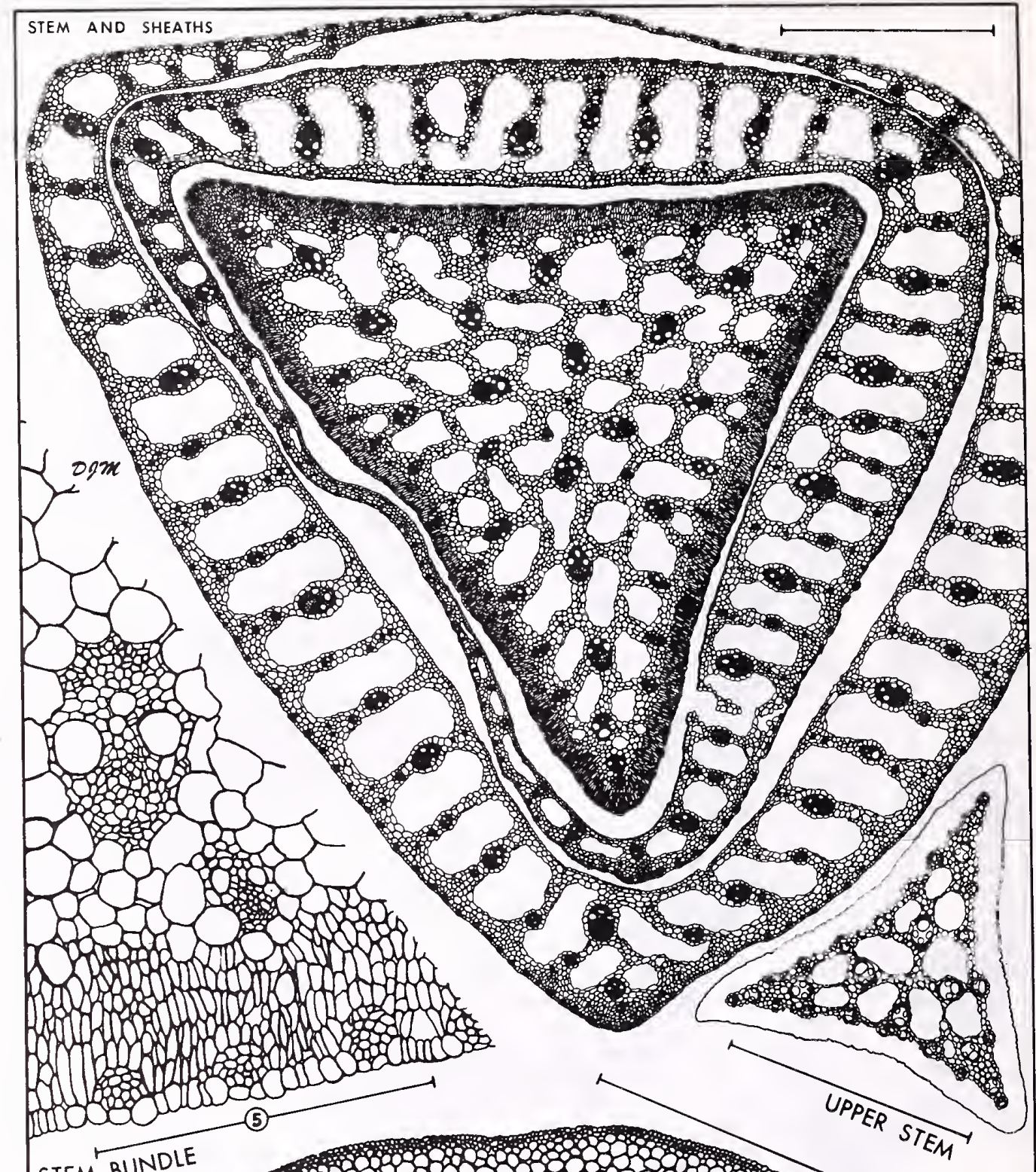

SCIRPUS

S. americanus

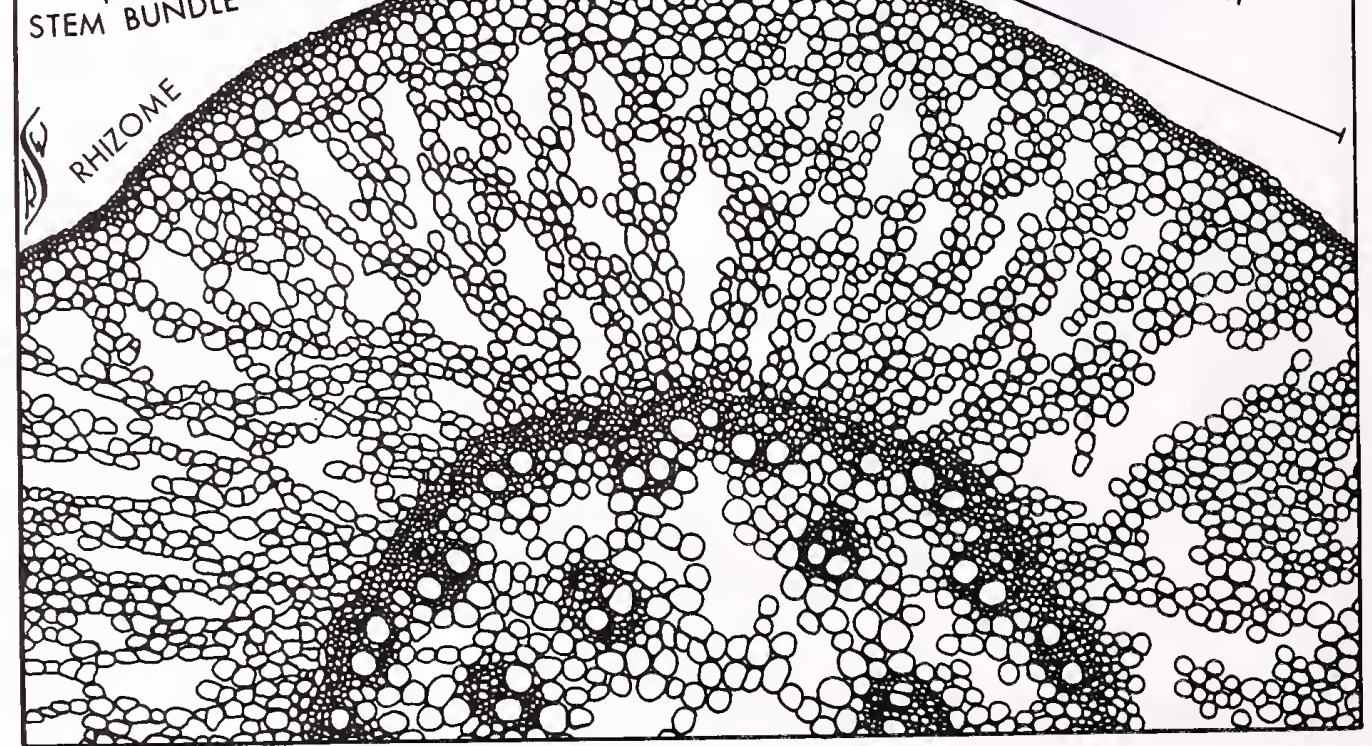




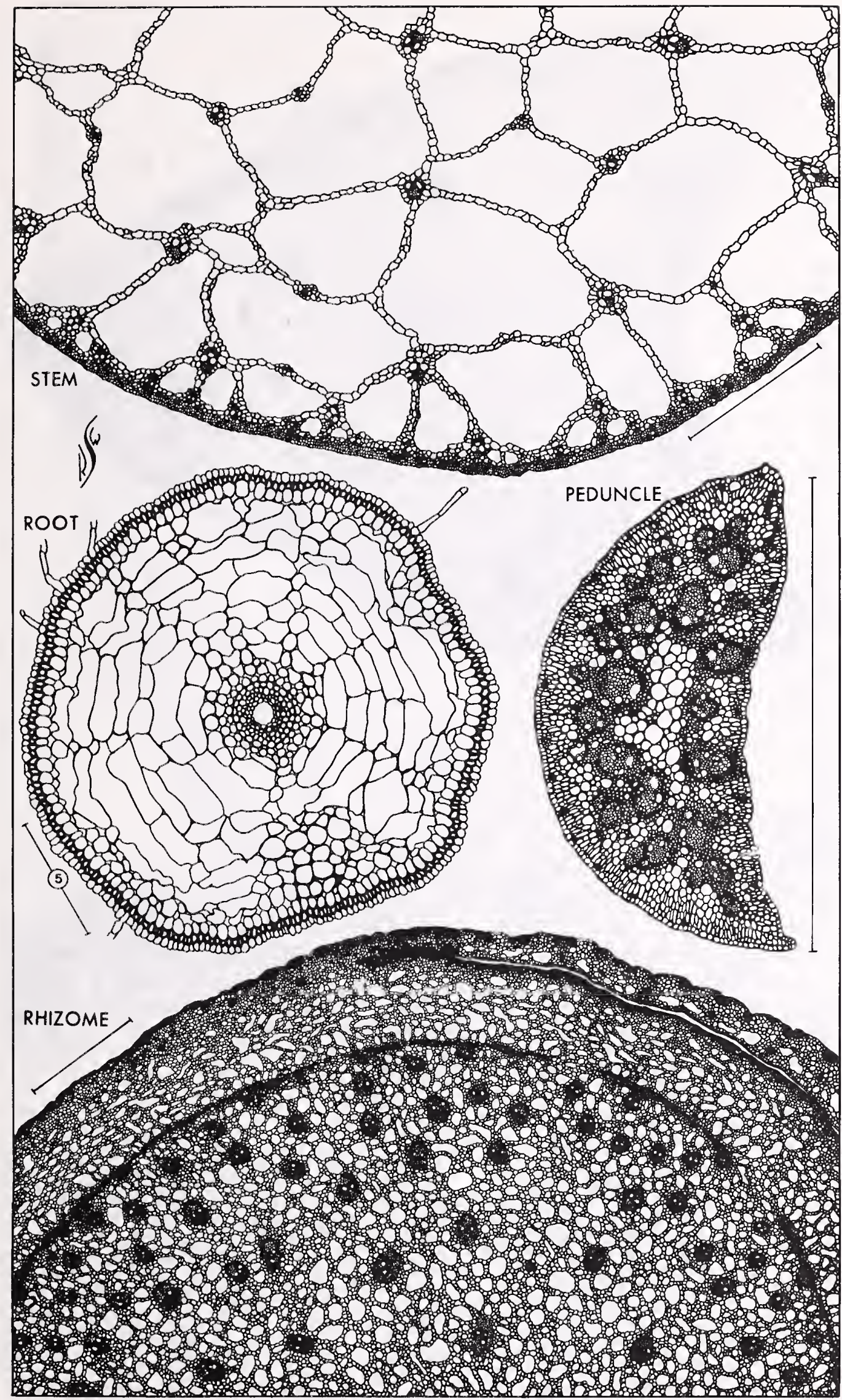

Plate 33

SCIRPUS

5. validus 
Plate 34

ACORUS

A. calamus

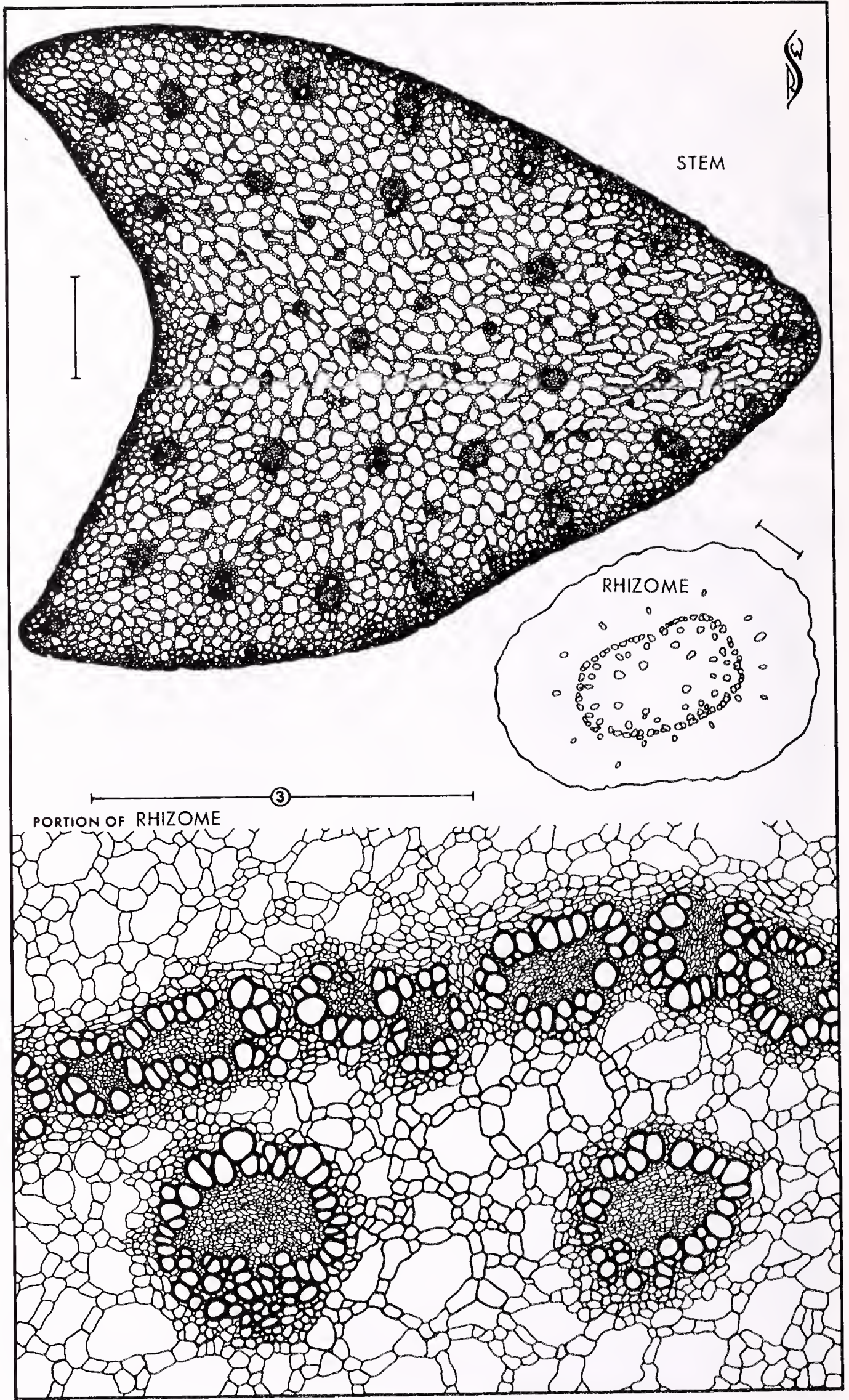




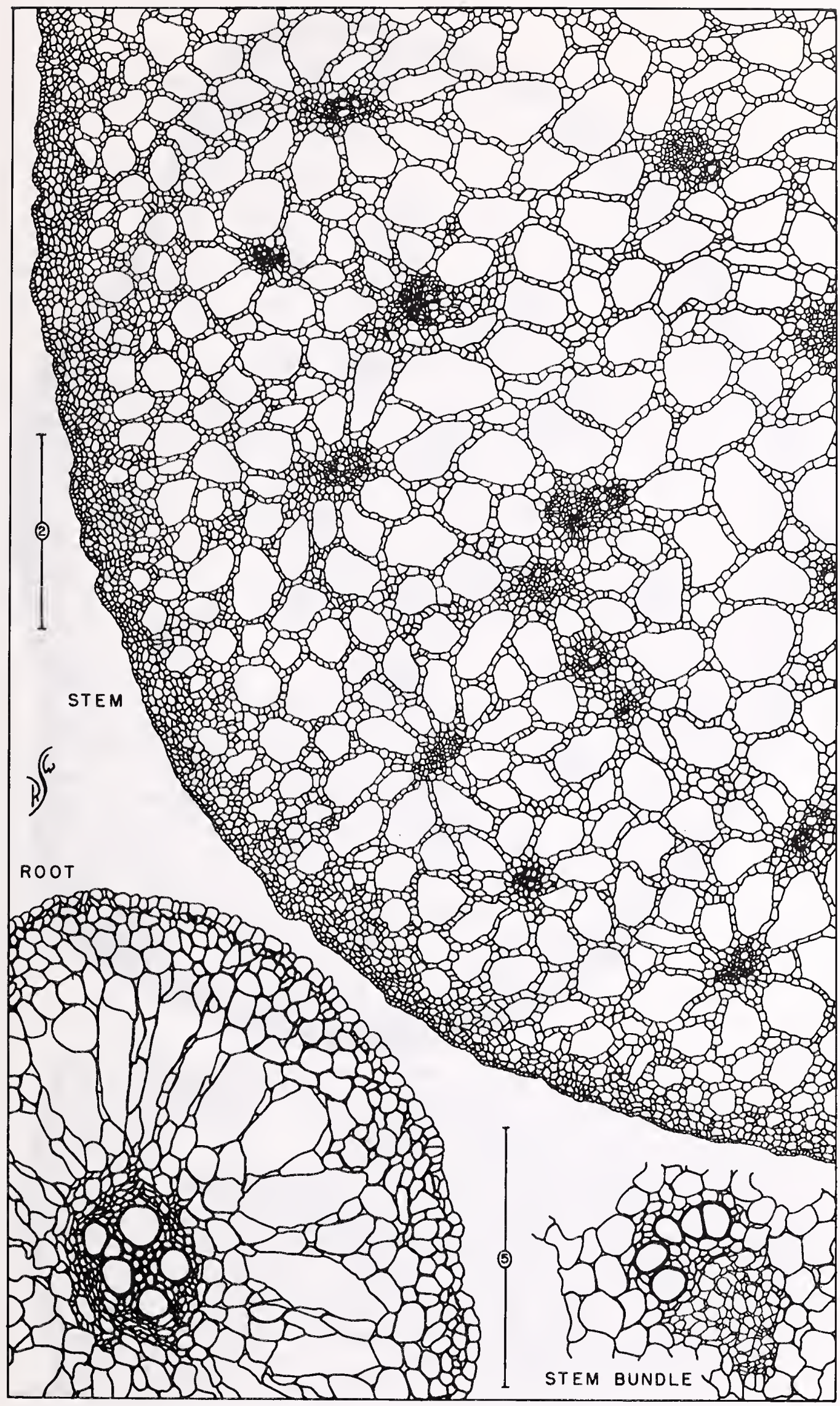

Plate 35

CALla

C. palustris 
Plate 36

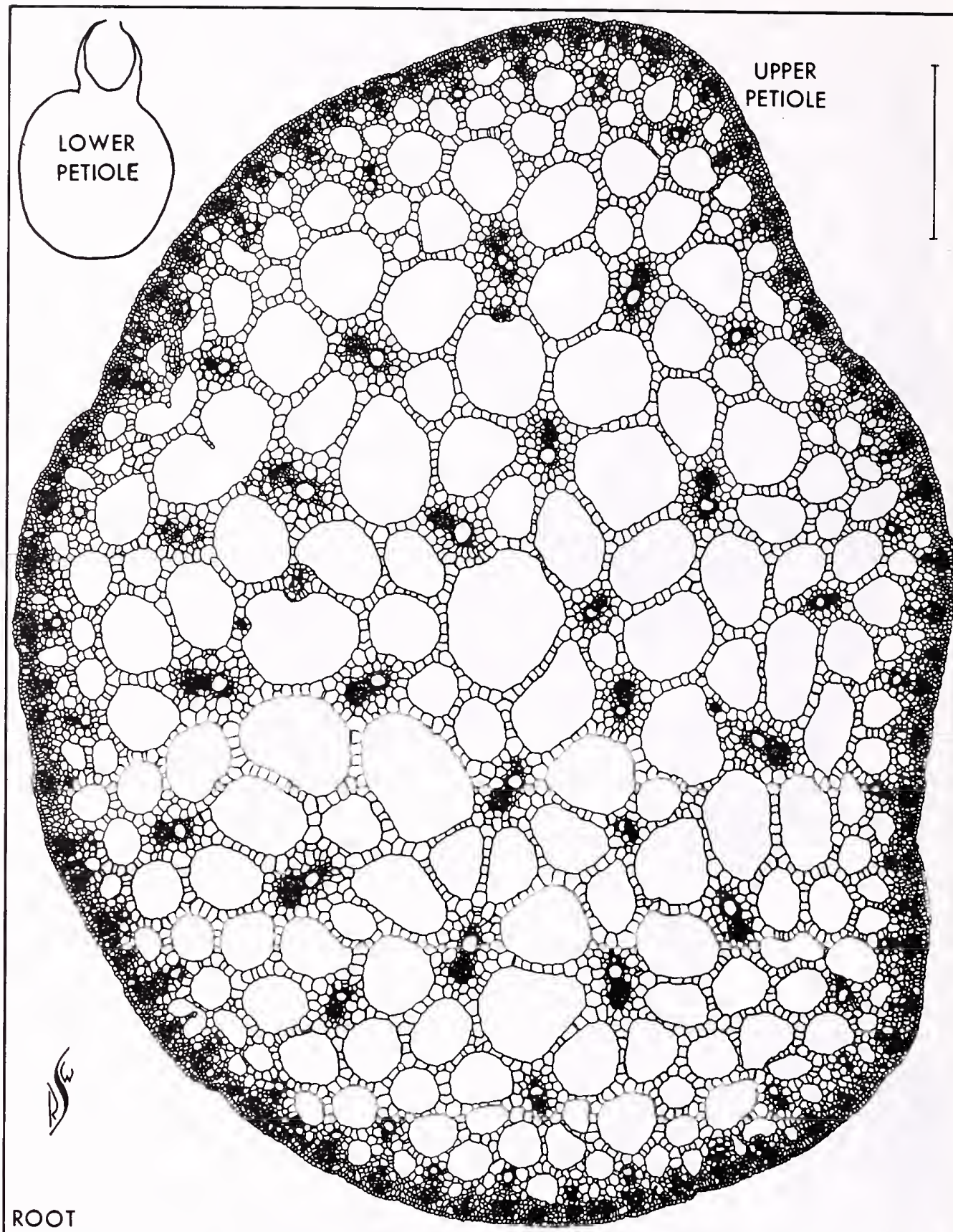

PELTANDRA

P. virginica

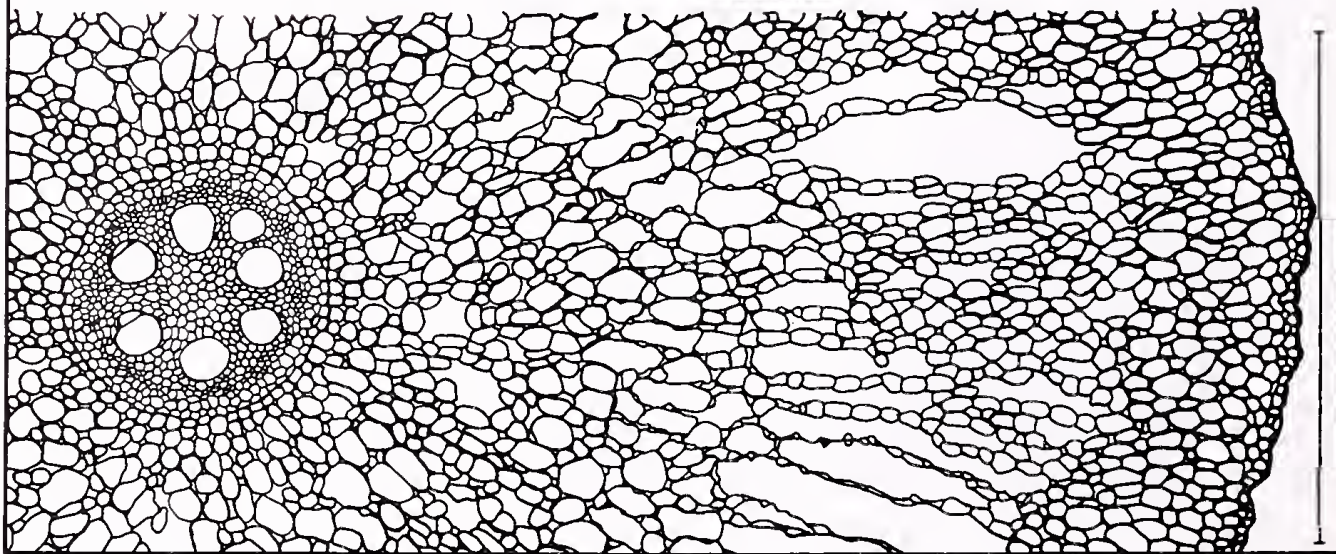




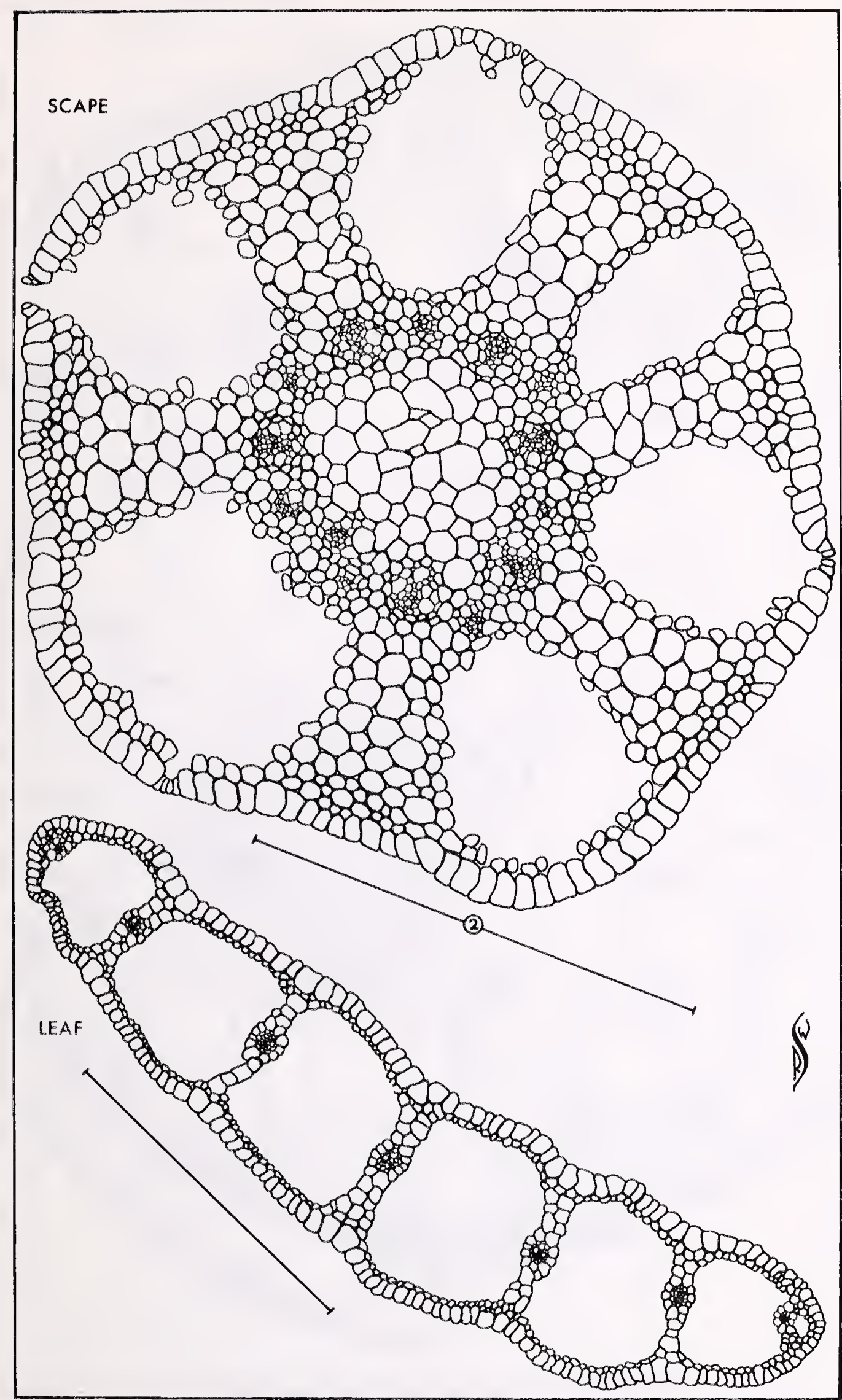

Plate 37

ERIOCAULON

E. septangulare 
HETERANTHERA

H. dubia

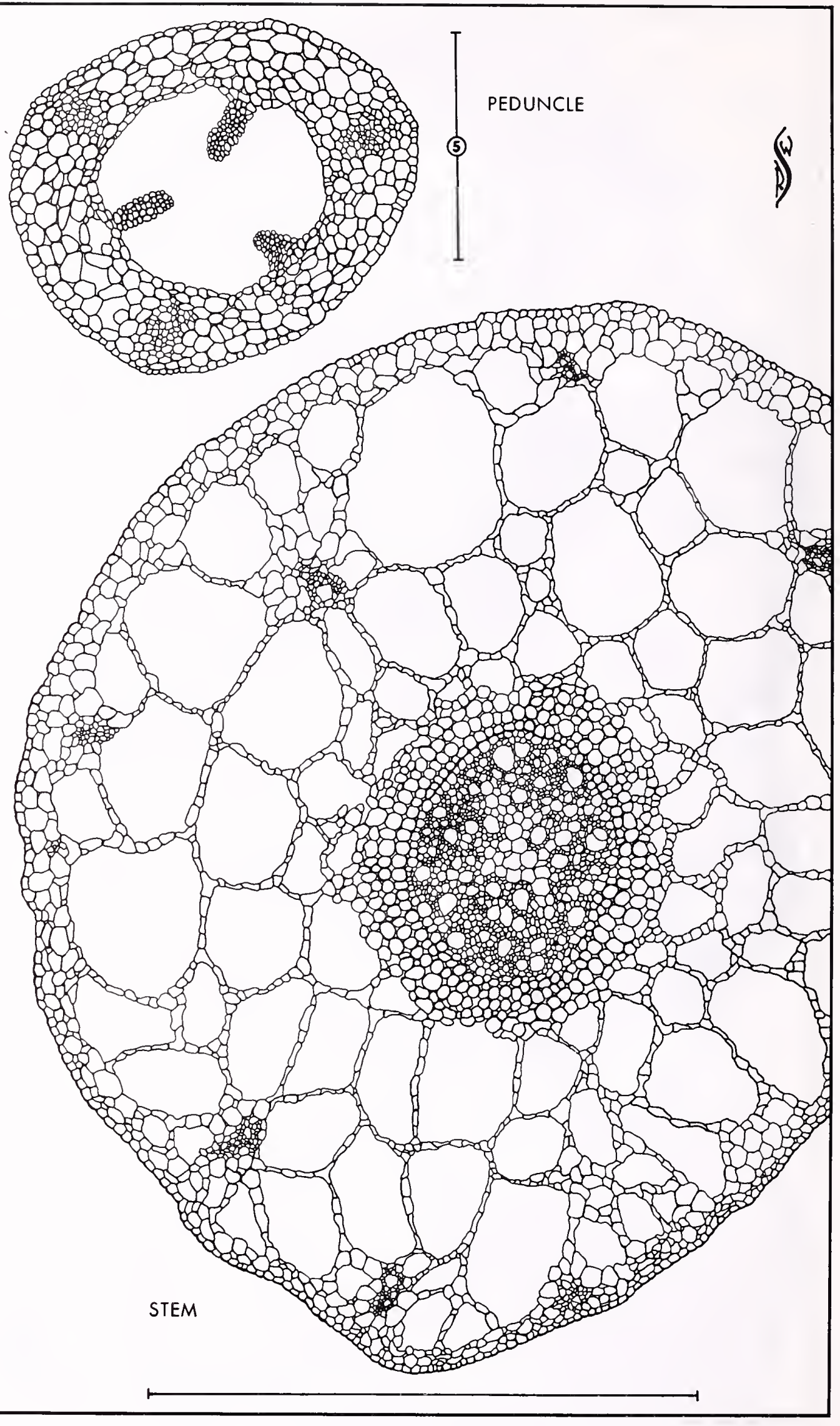




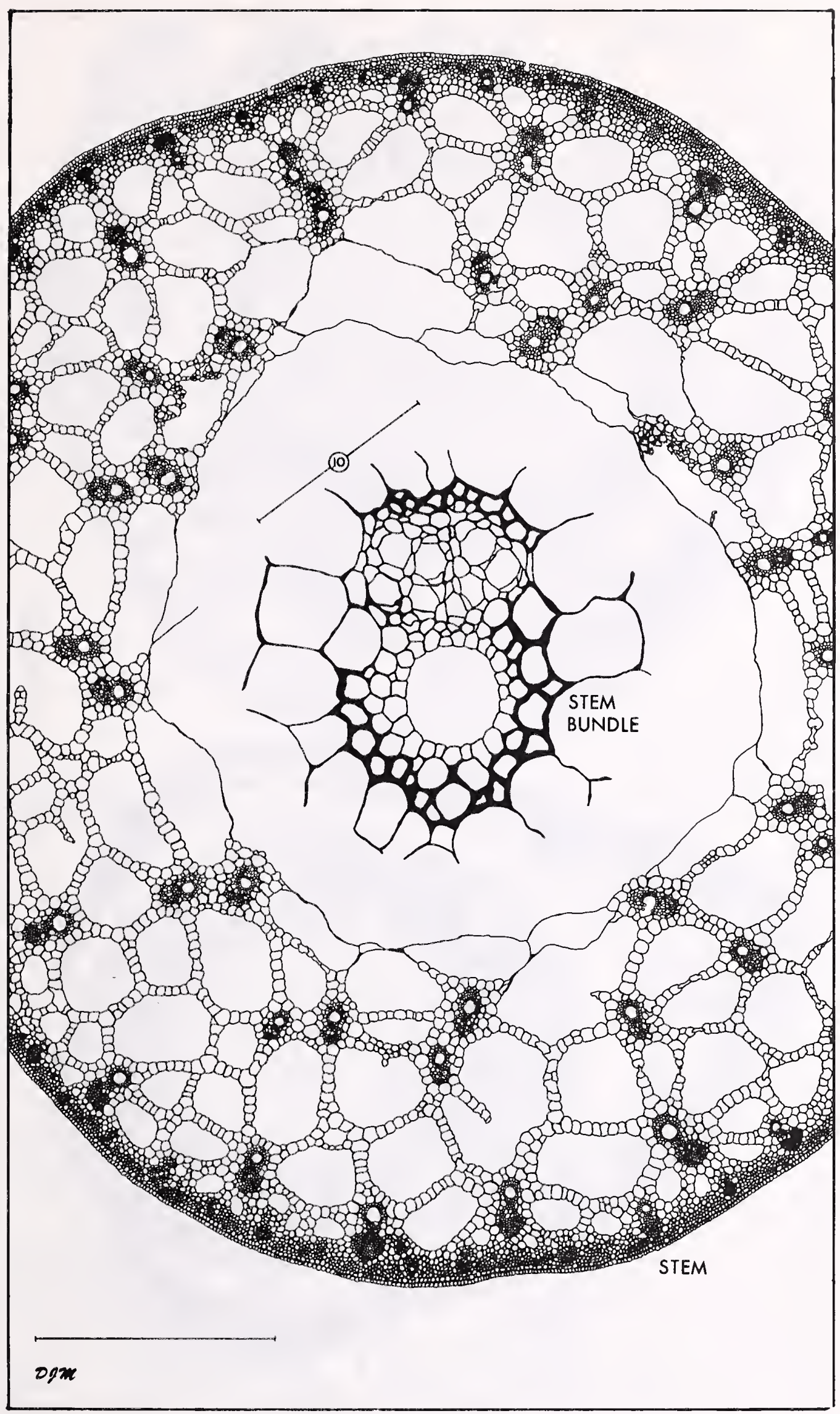

Plate 39

PONTEDERIA

P. cordata 
JUNCUS

J. articulatus

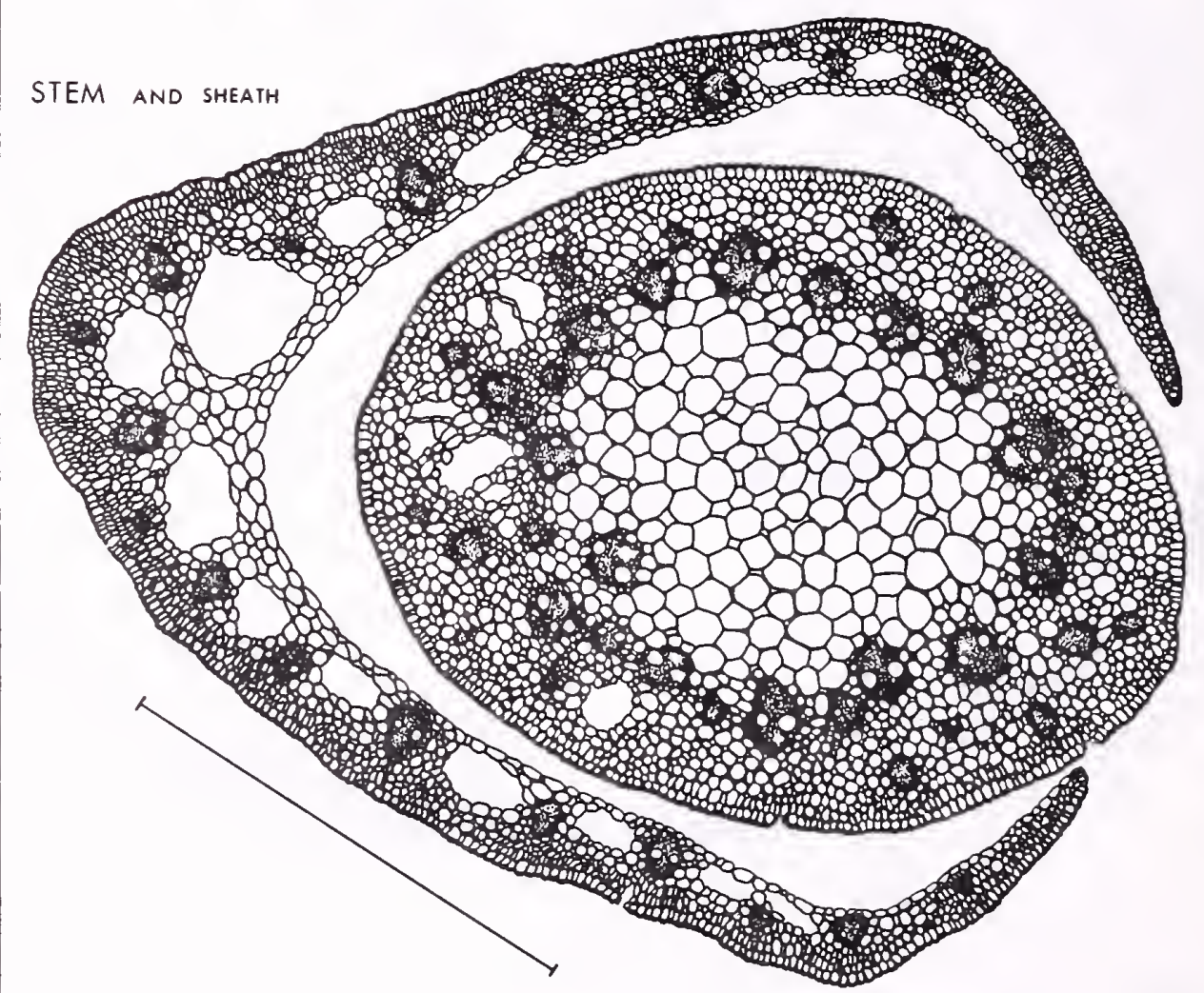




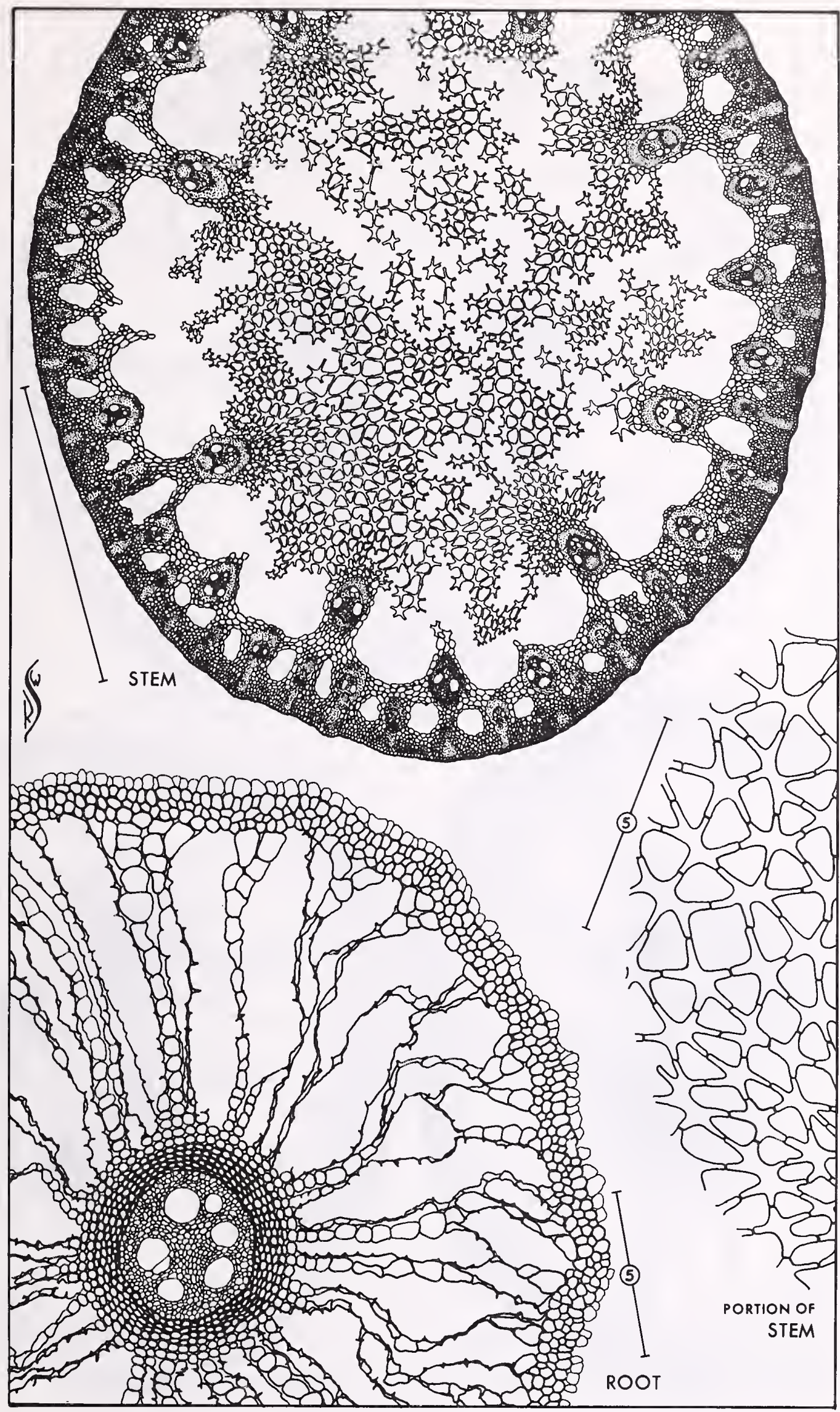

JUNCUS

J. effusus 


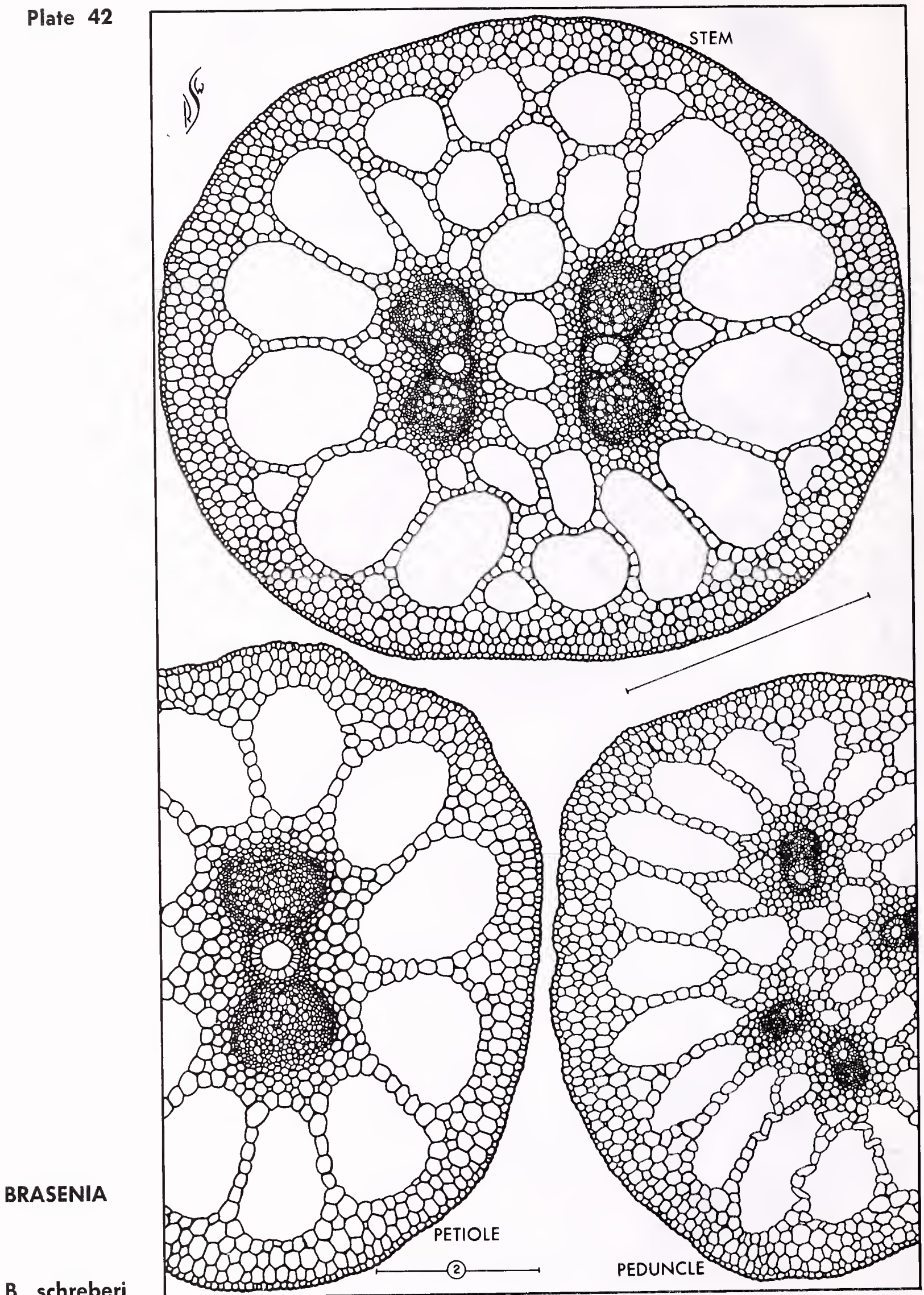




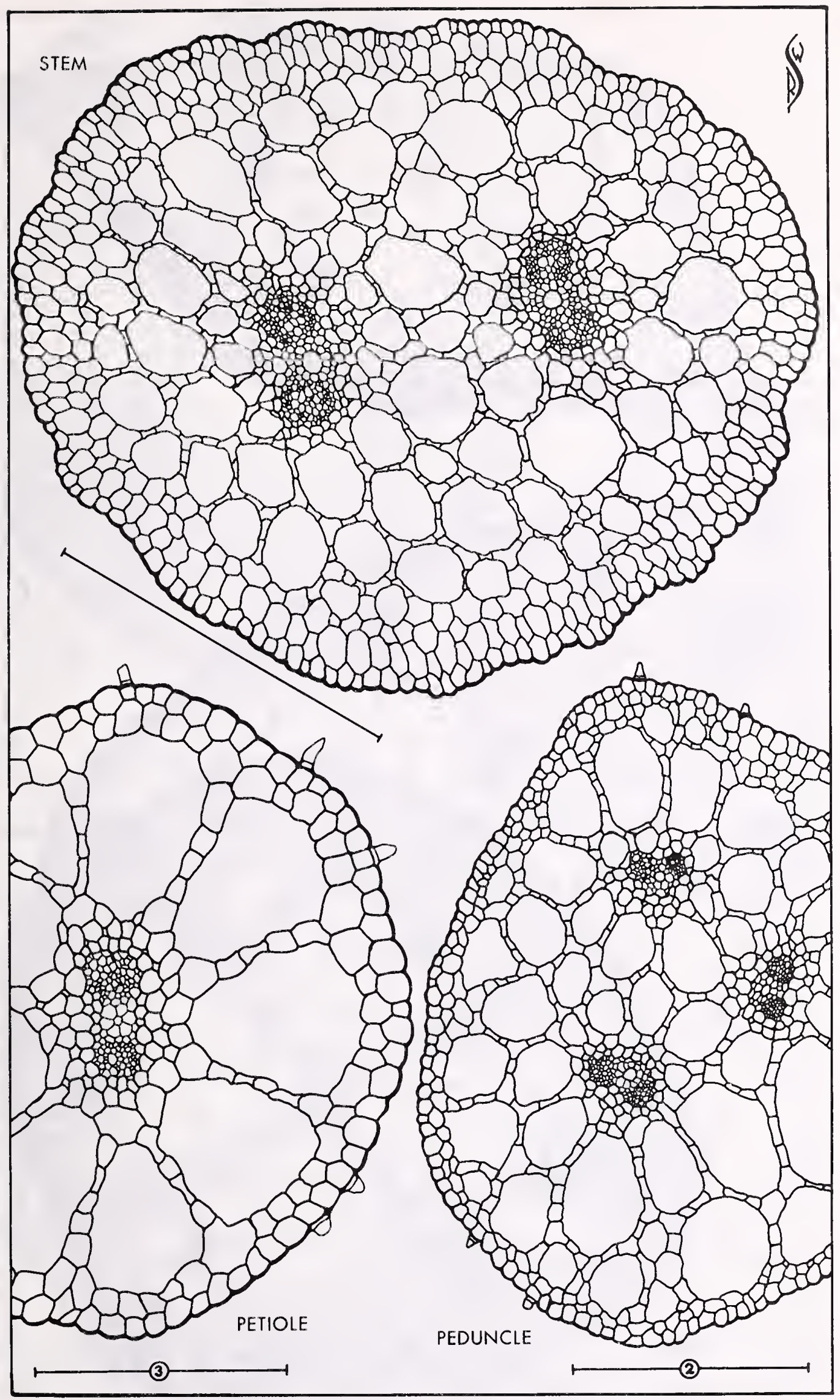

Plate 43

CABOMBA

C. caroliniana 
NUPHAR

N. luteum

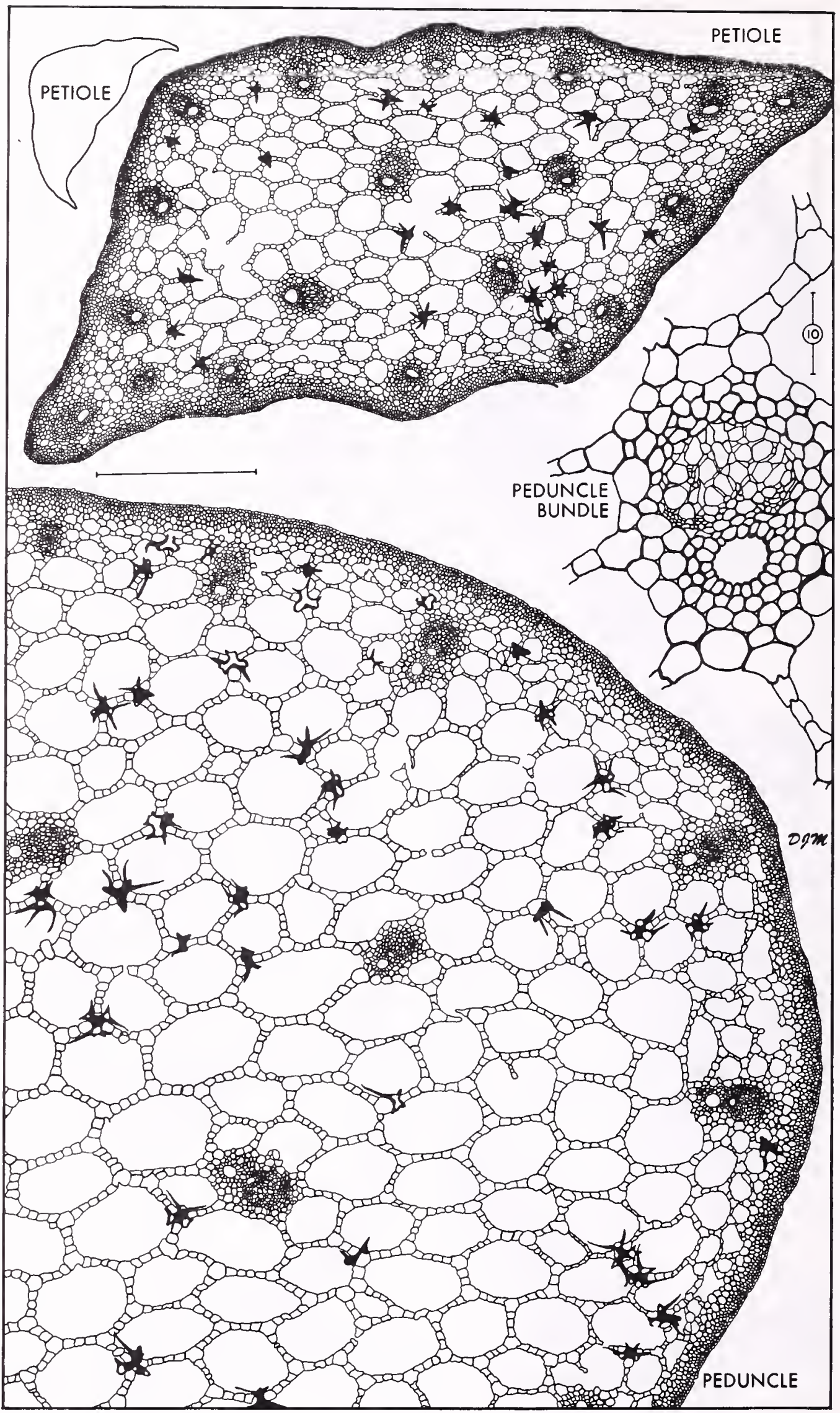




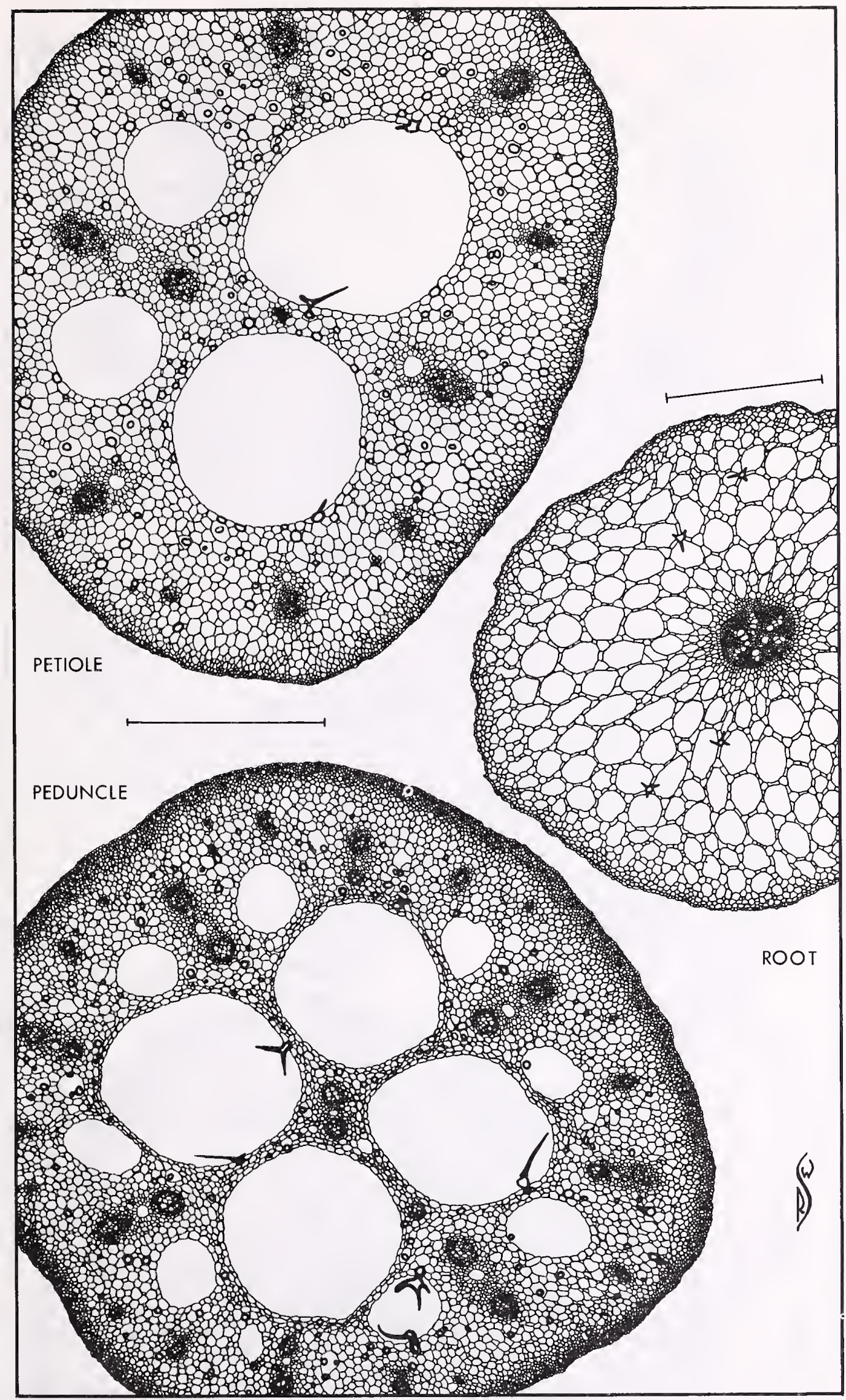

Plate 45

NYMPHAEA

N. odorata 
CERATOPHYLLUM

C. demersum

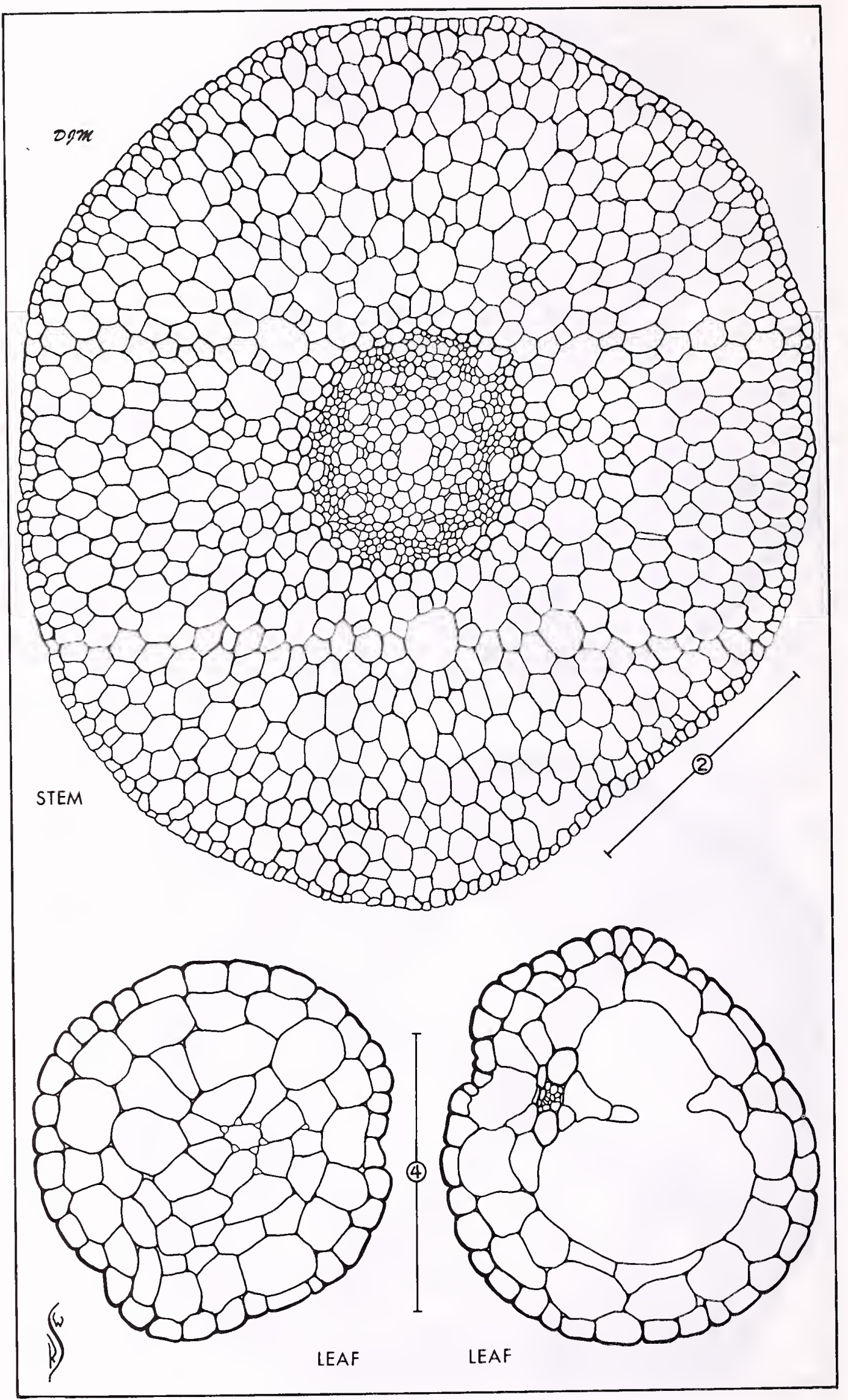




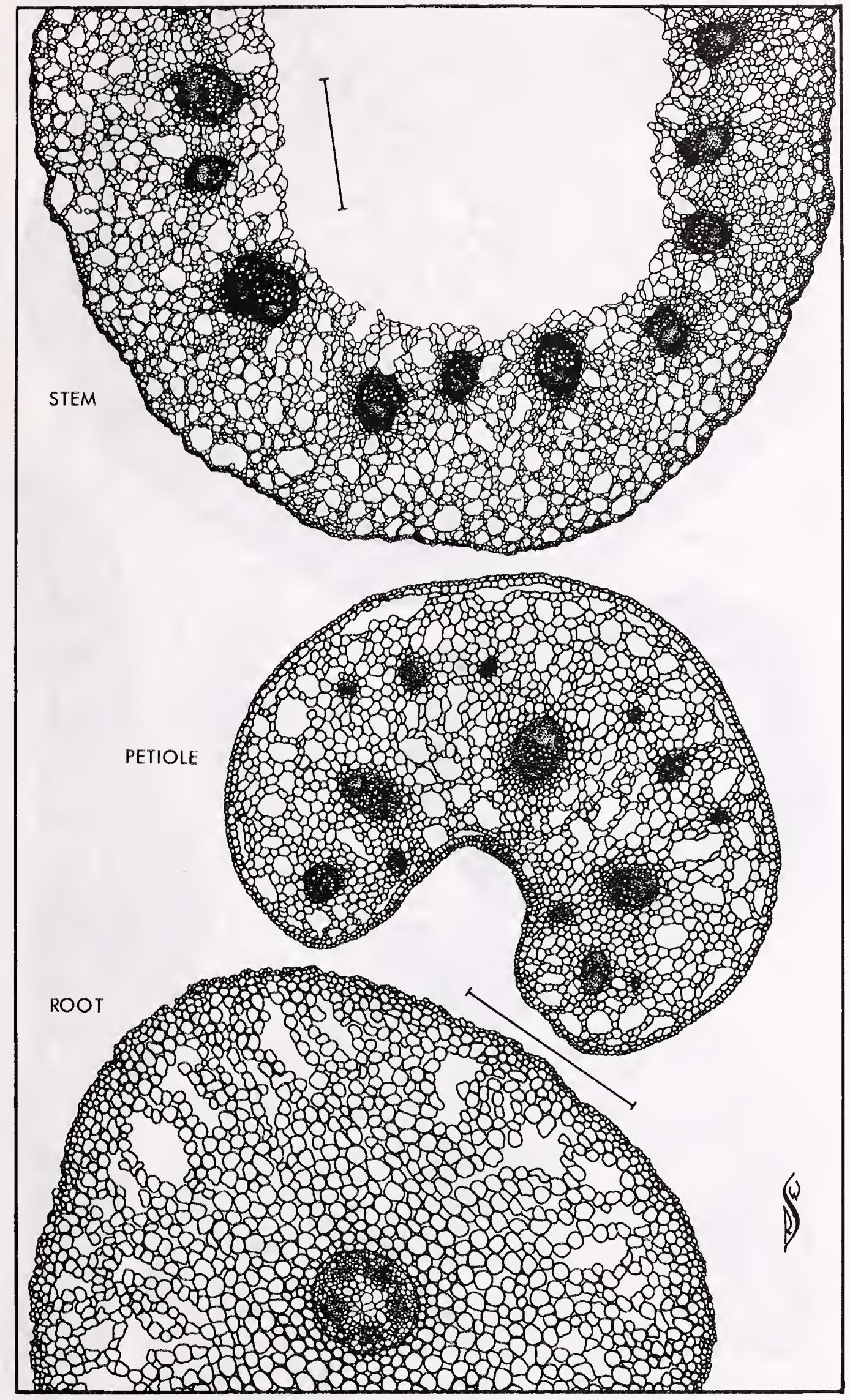

Plate 47

CALTHA

C. palustris 


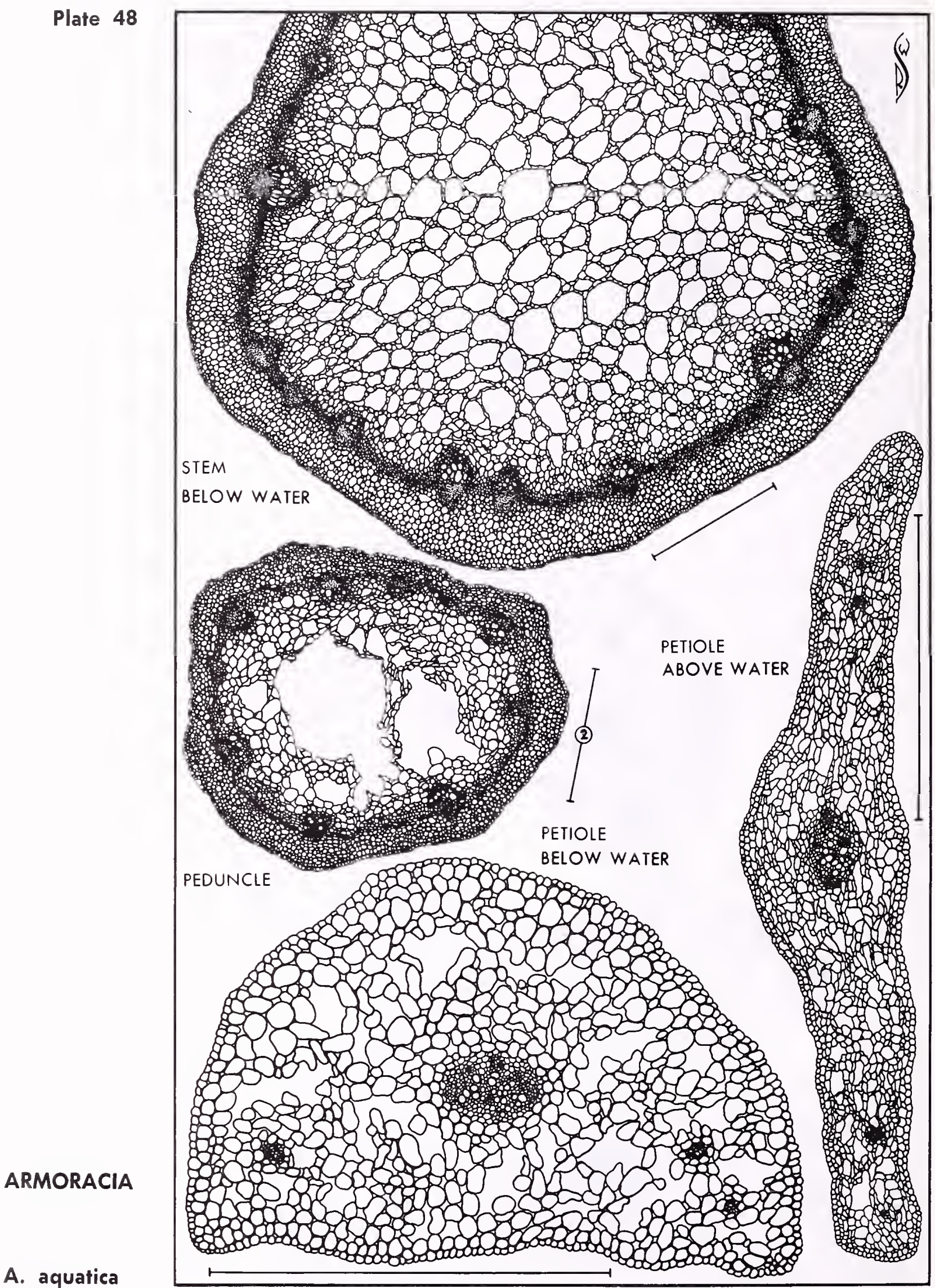




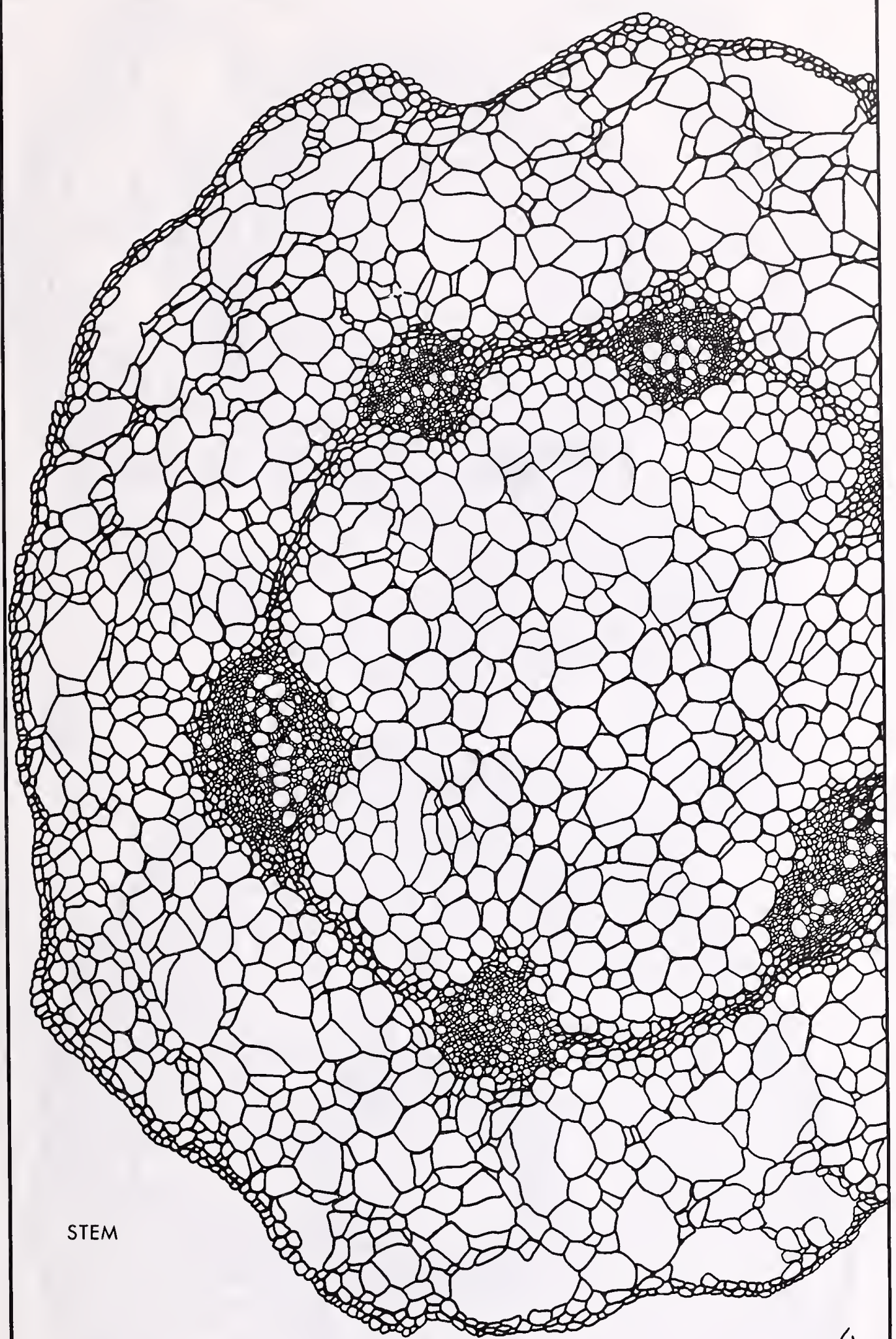

$(4)$
NASTURTIUM

N. officinale 
HYPERICUM

TRIADENUM

H. ellipticum (A)

T. fraseri (B)

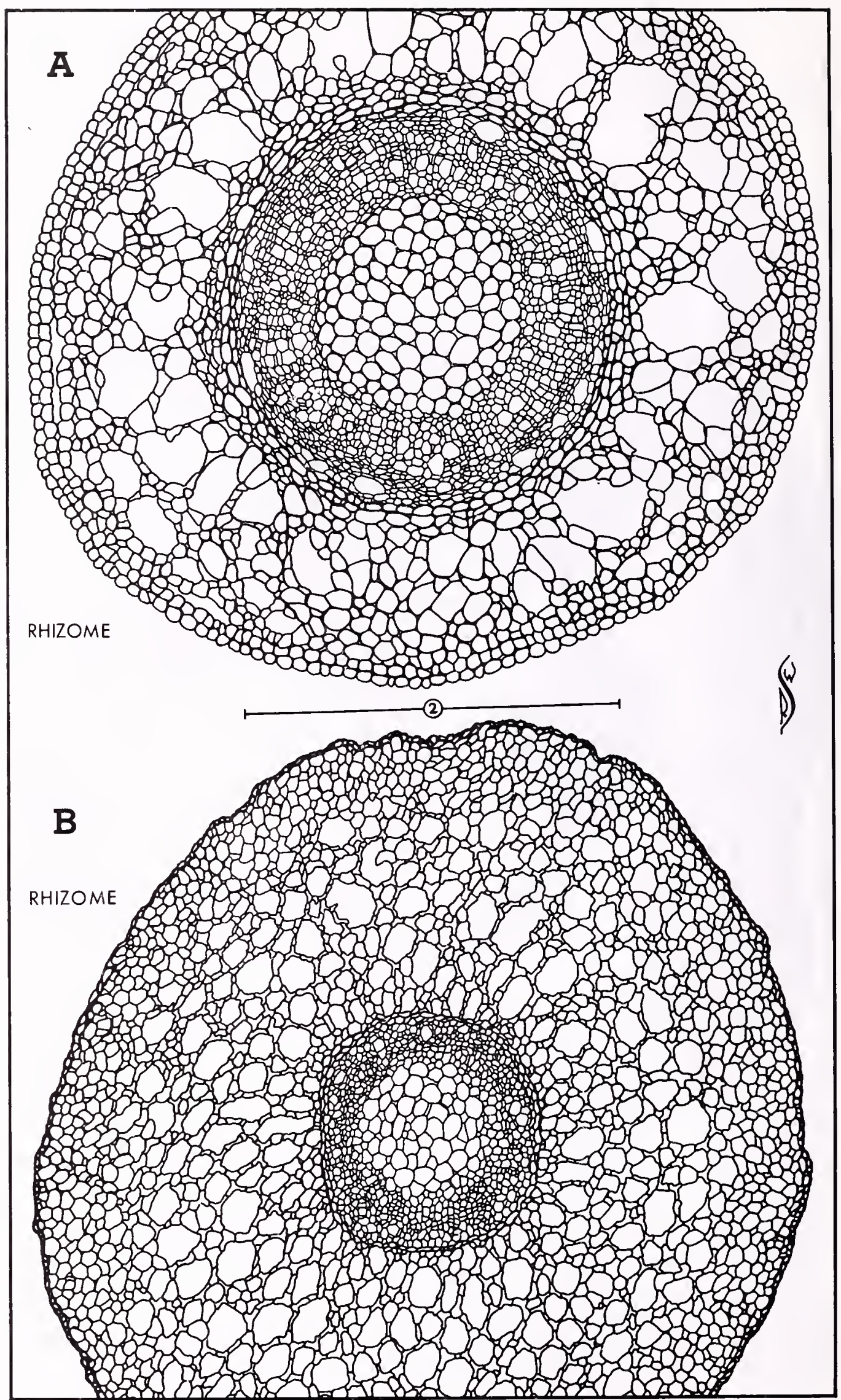




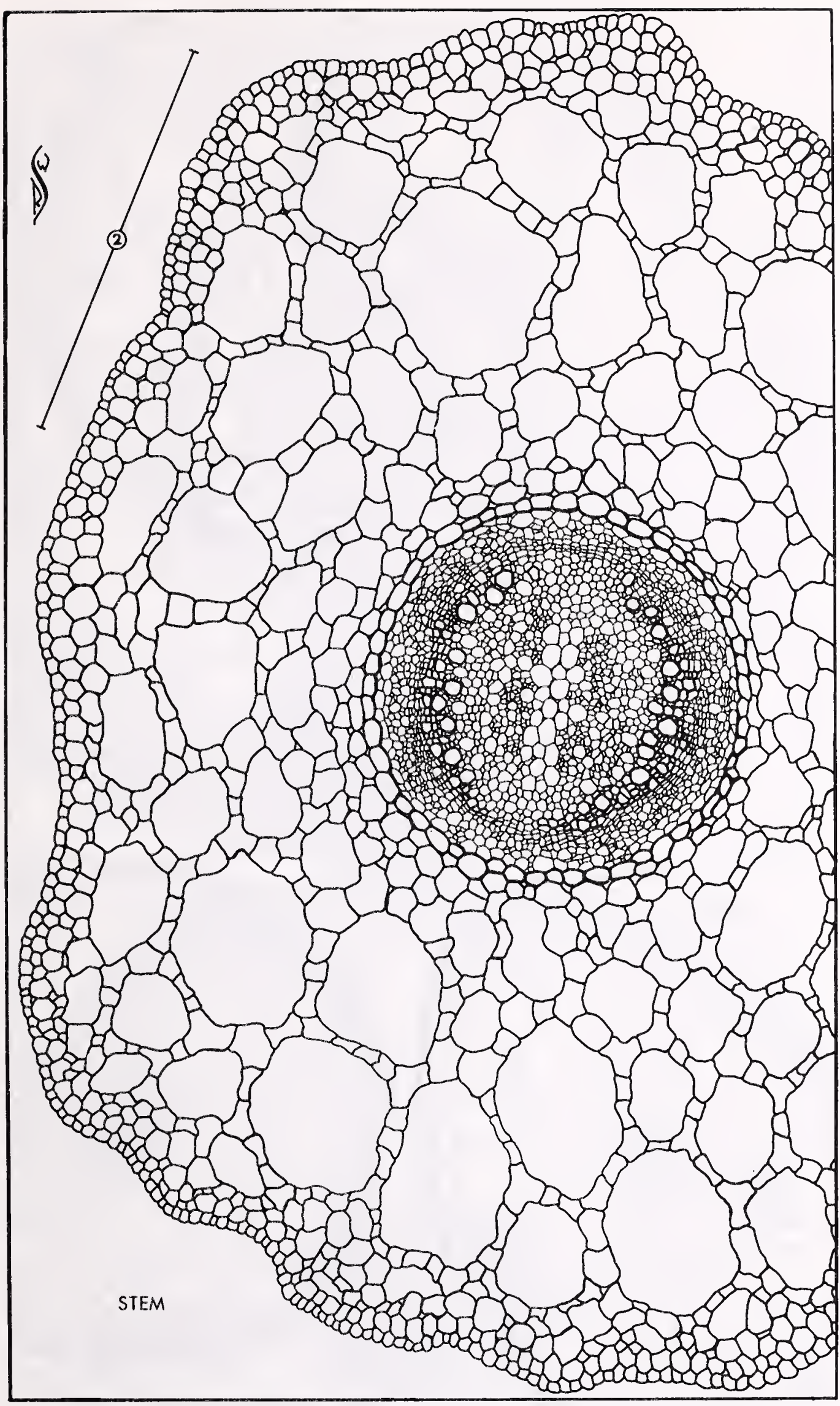

Plate 51

LUDWIGIA

L. palustris 


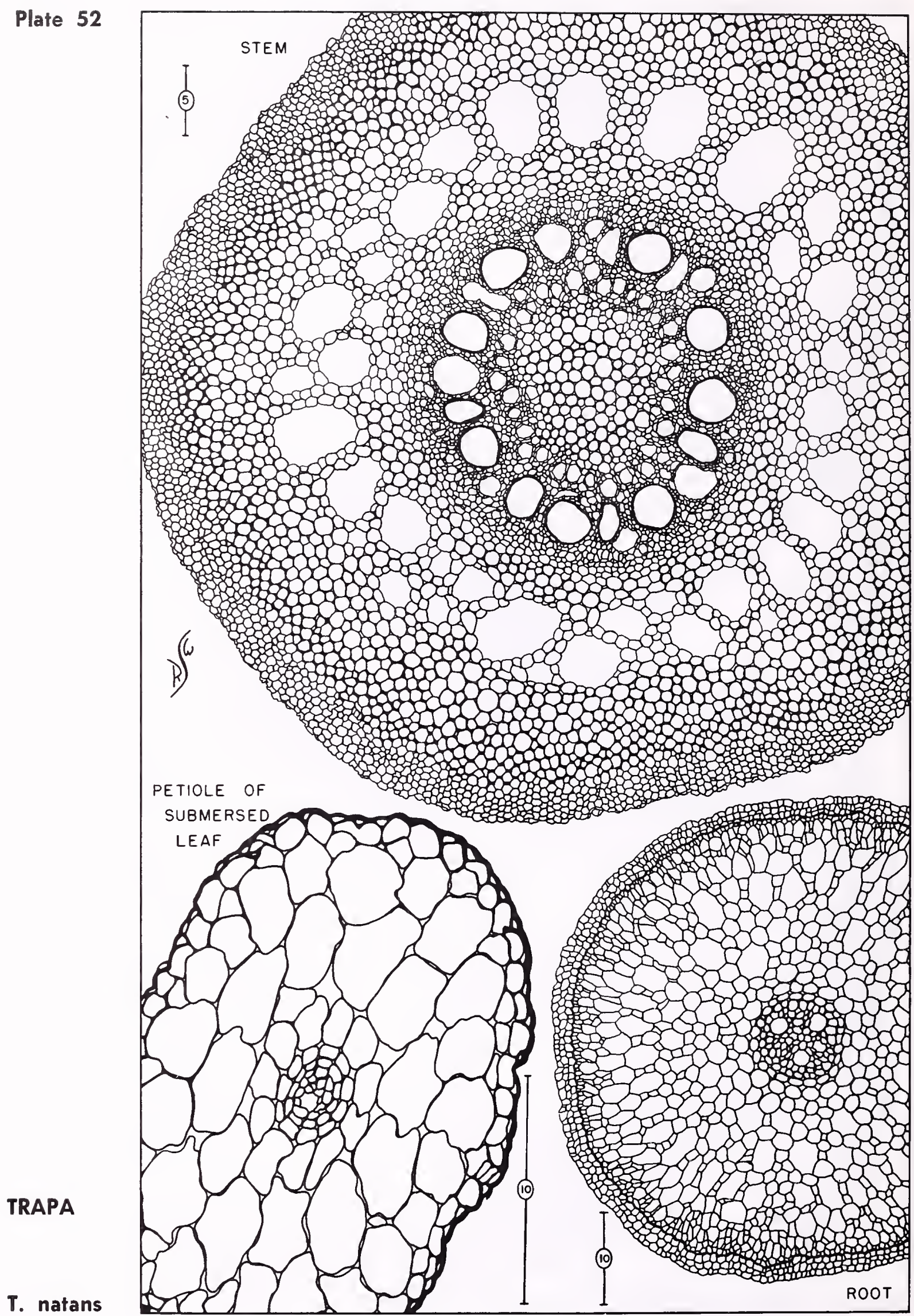




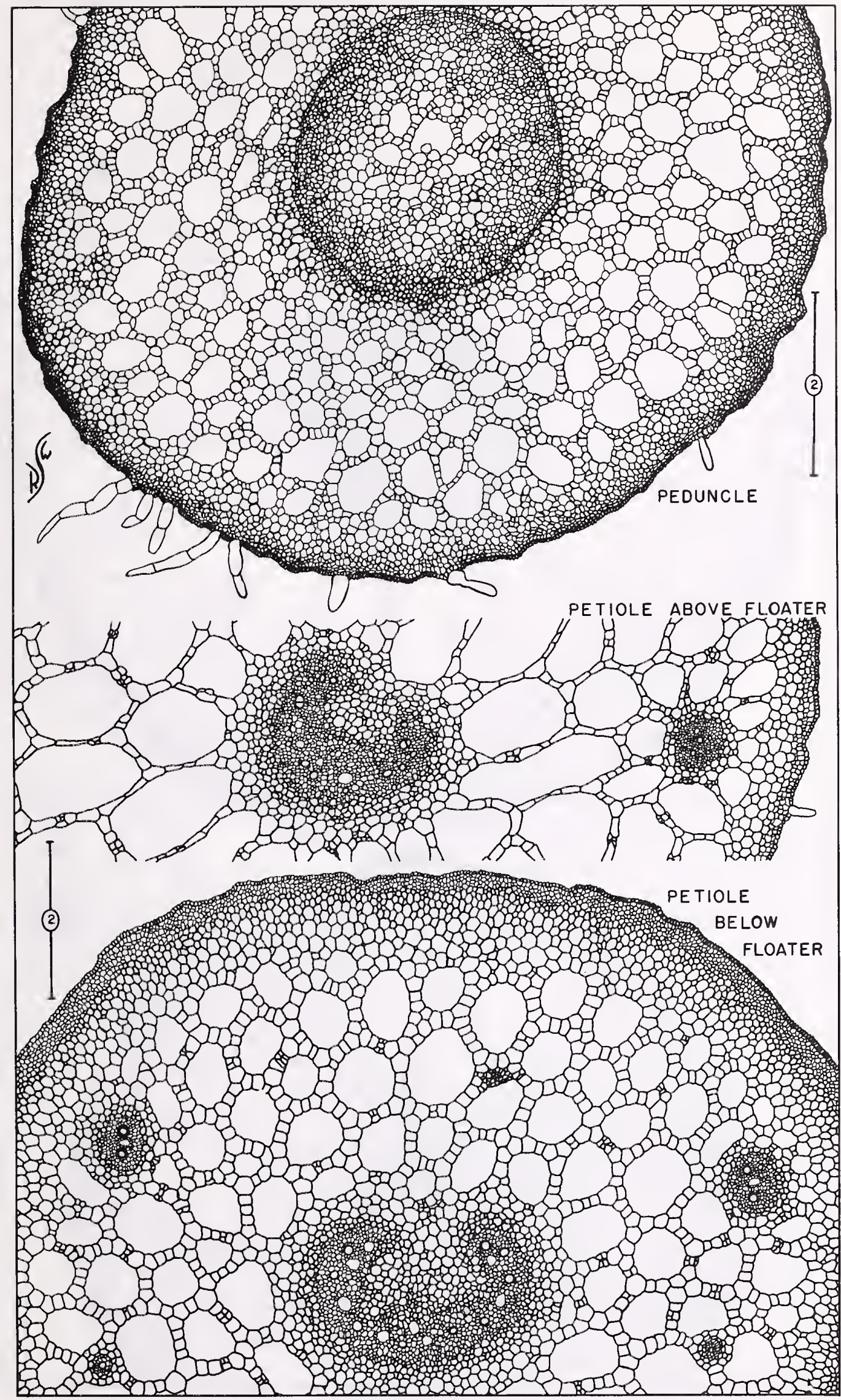

Plate 53

TRAPA

T. natans 
MYRIOPHYLLUM

M. brasiliense

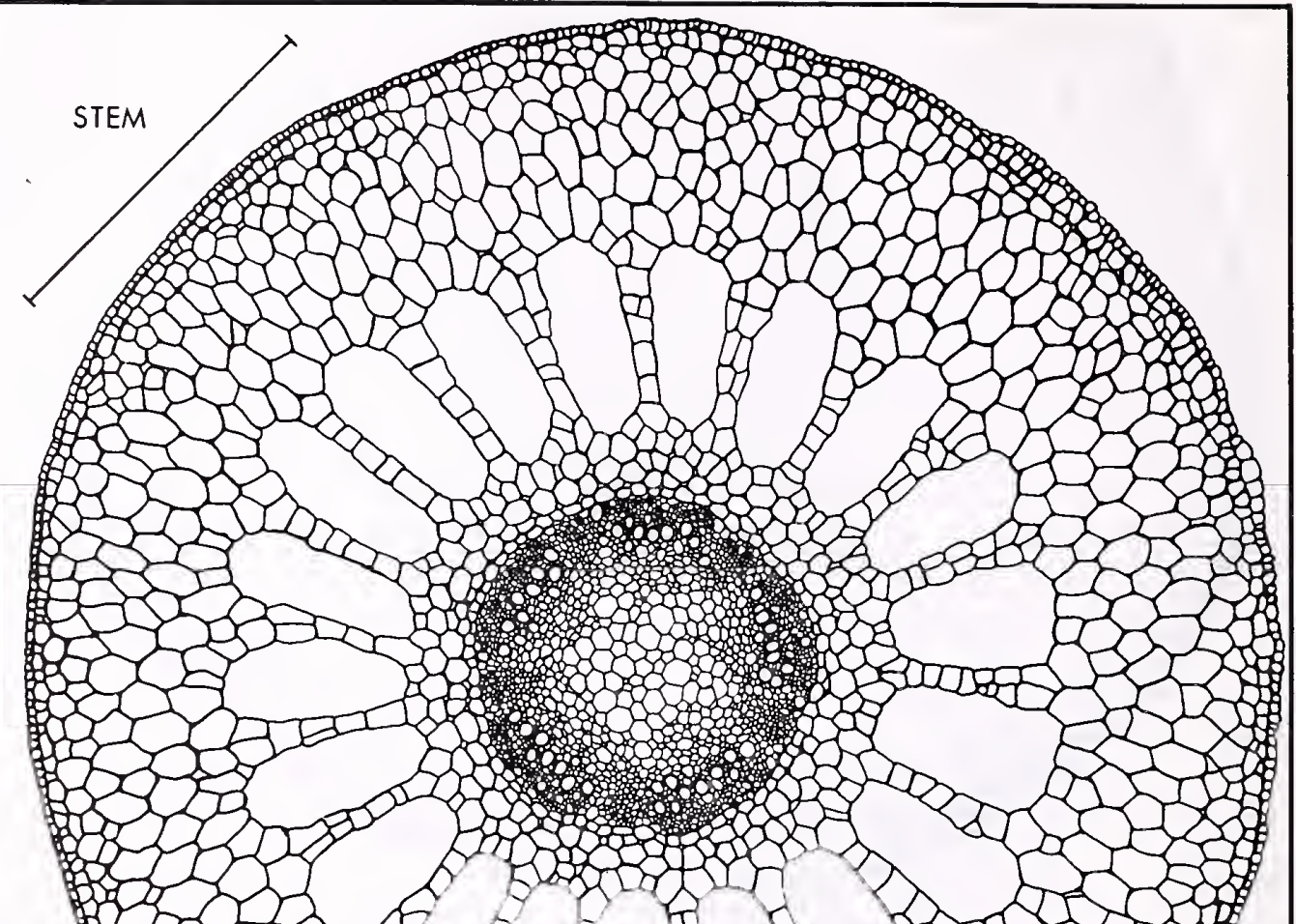

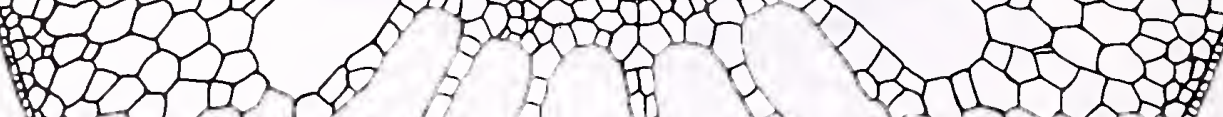

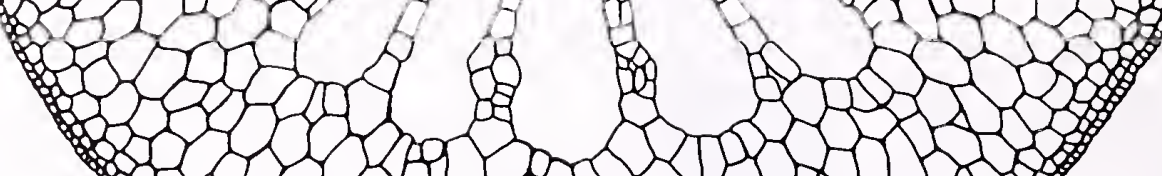

(2)
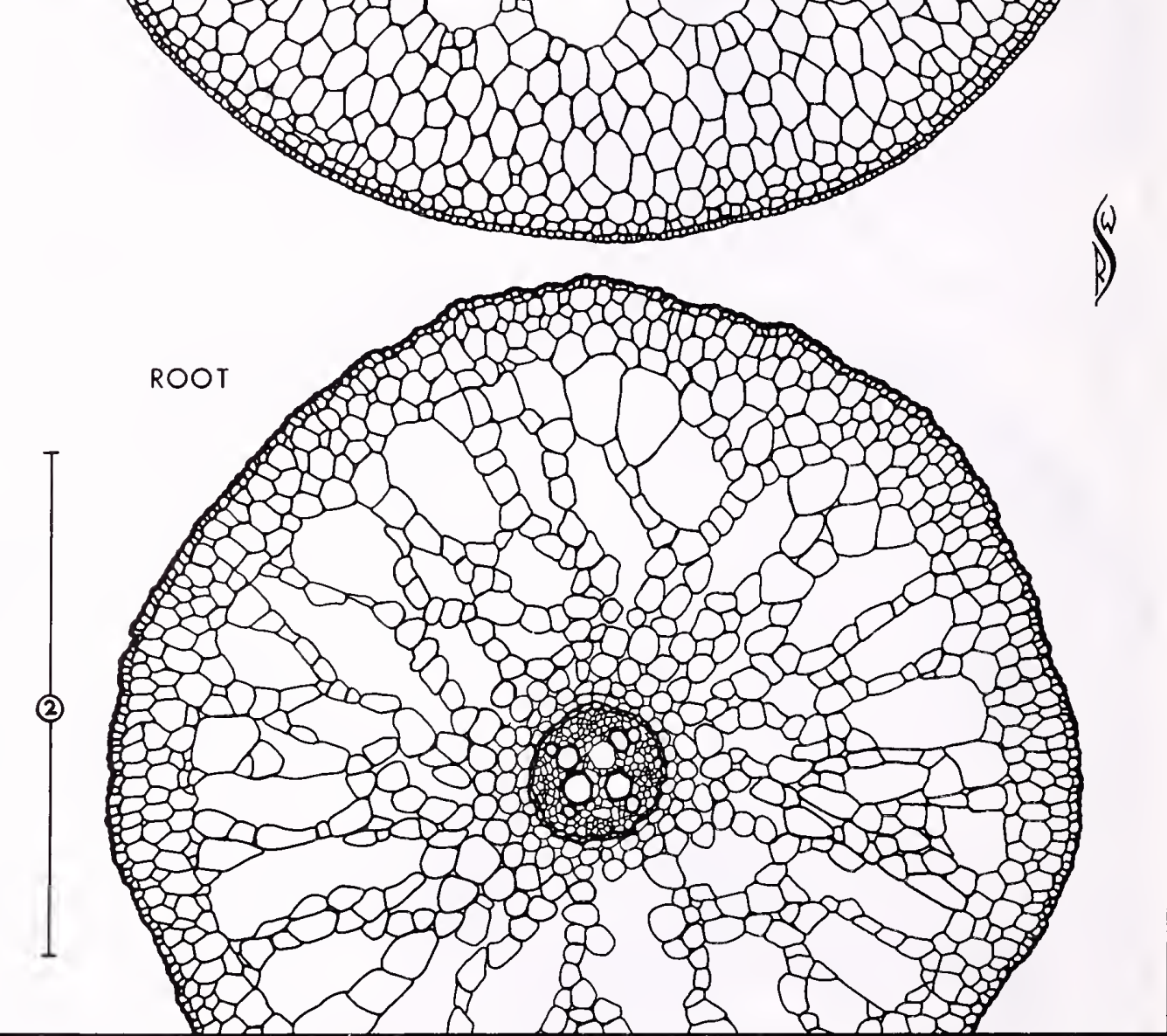


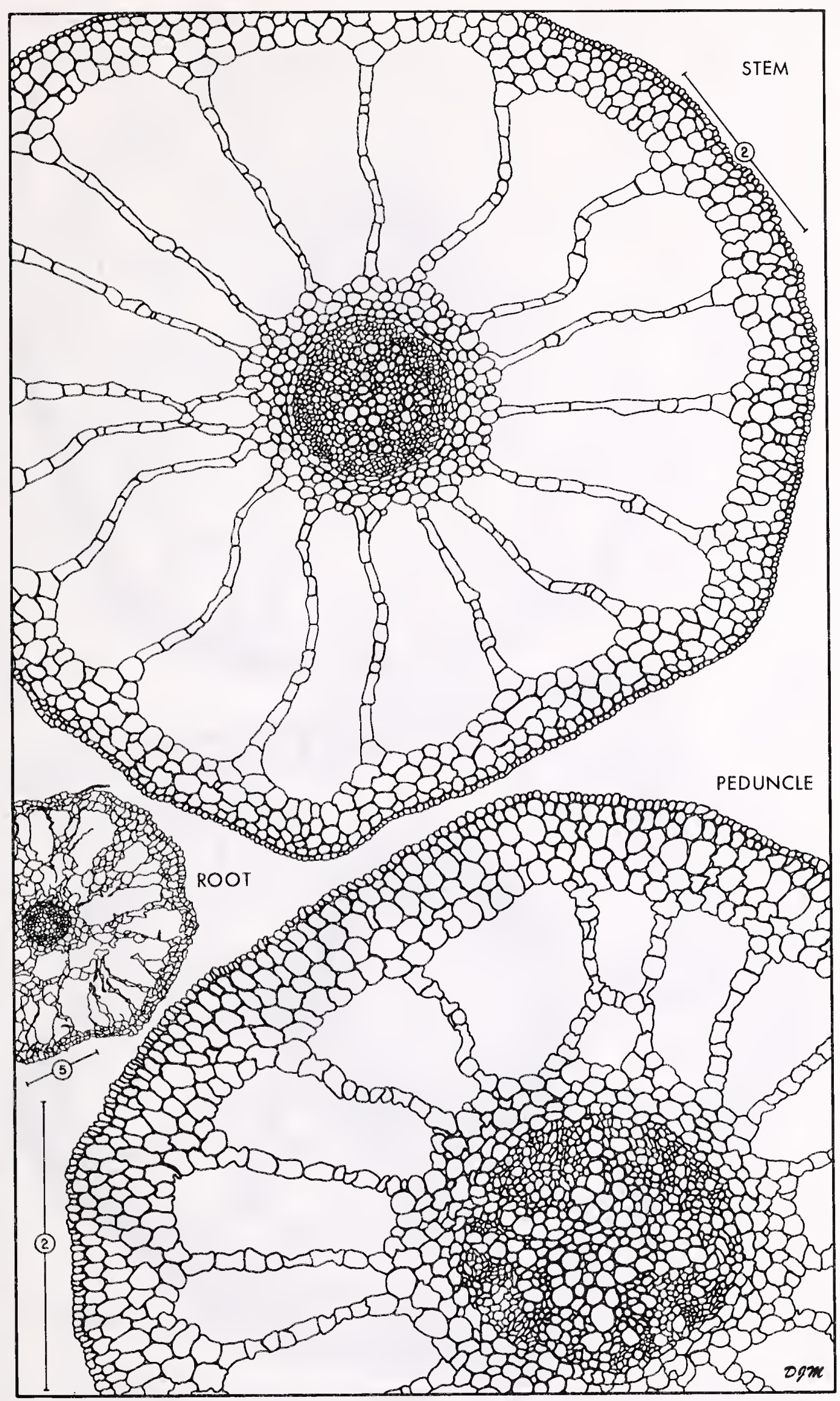

Plate 55 


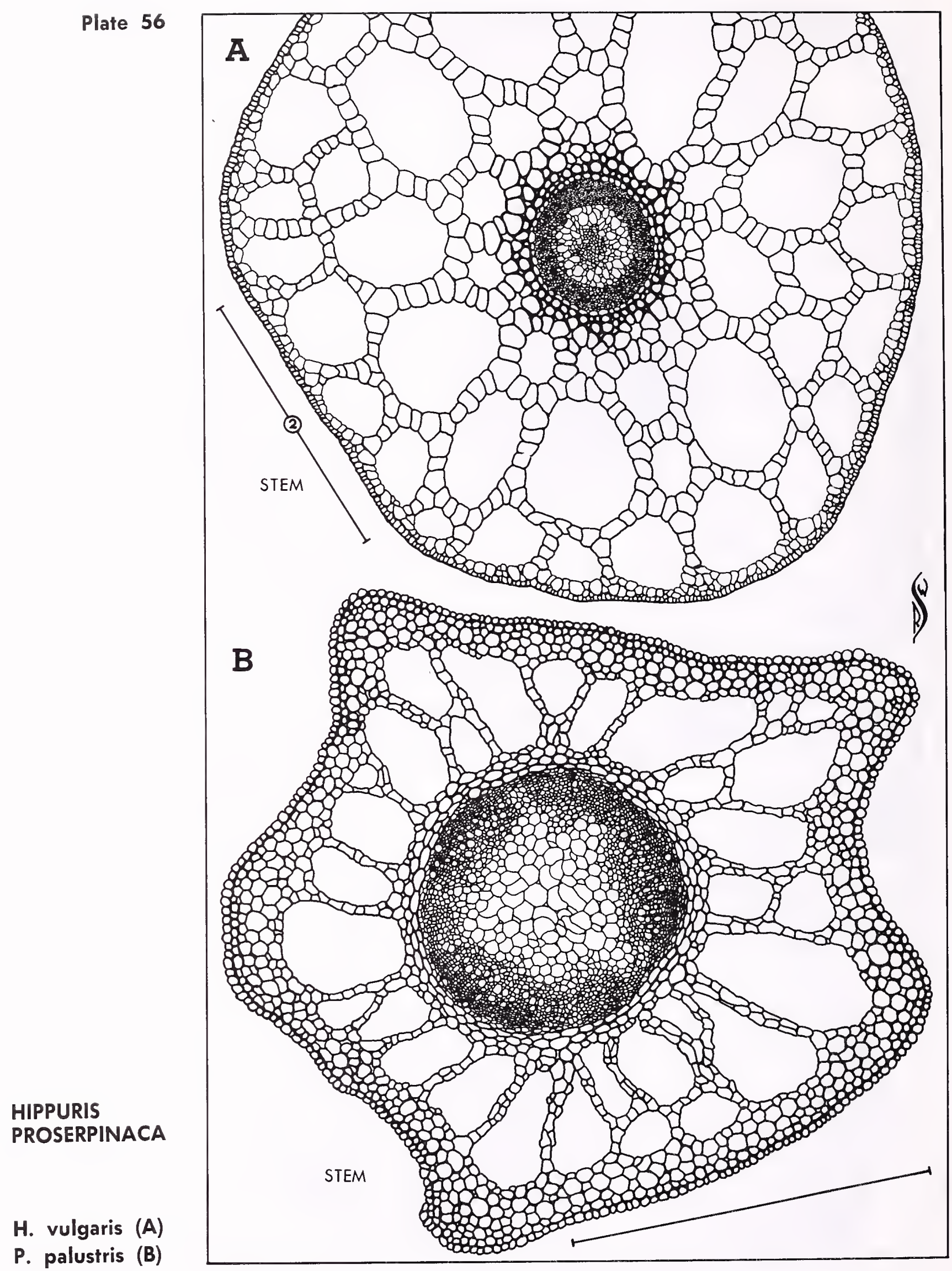




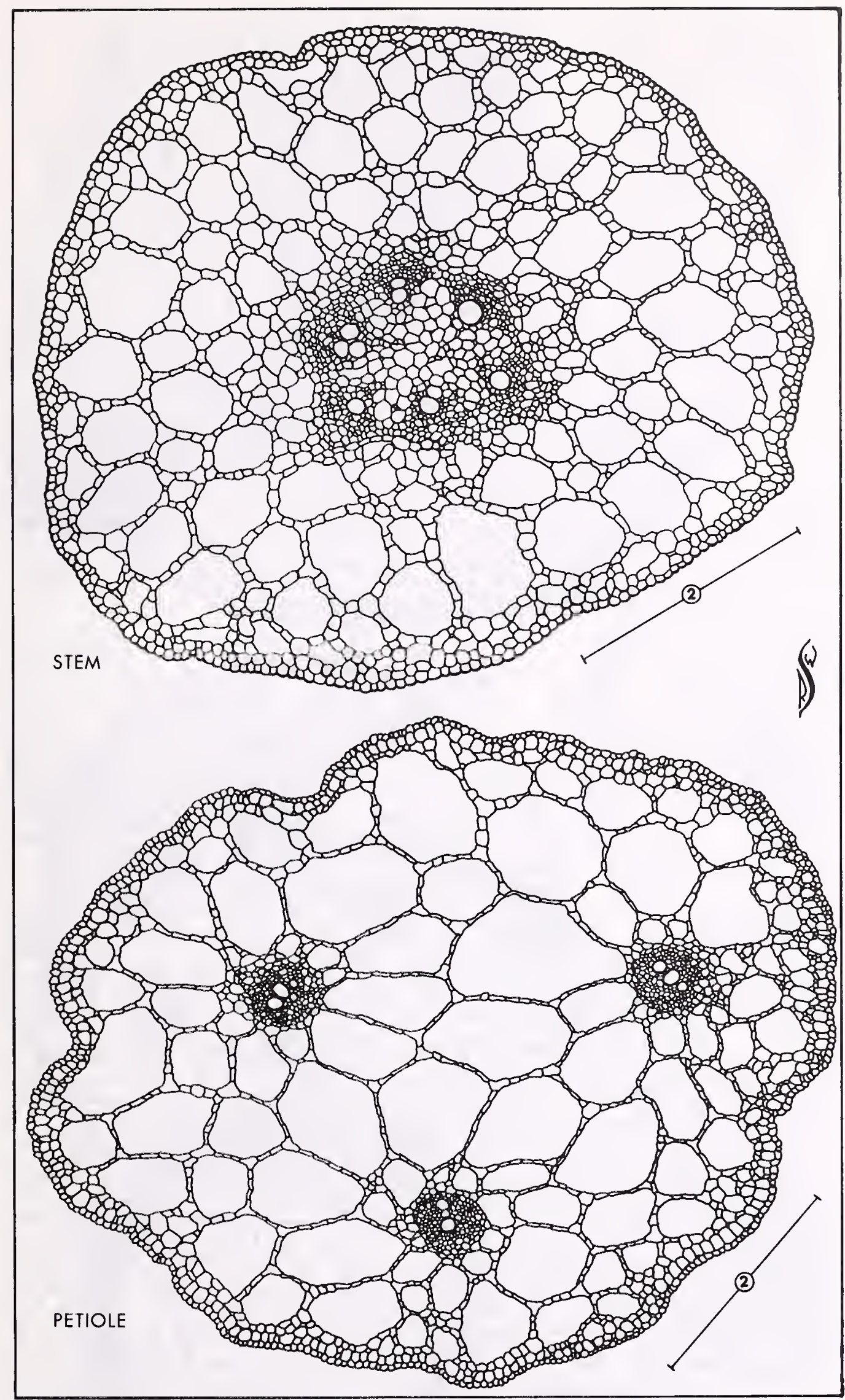

Plate $\mathbf{5 7}$

HYDROCOTYLE

H. umbellata 


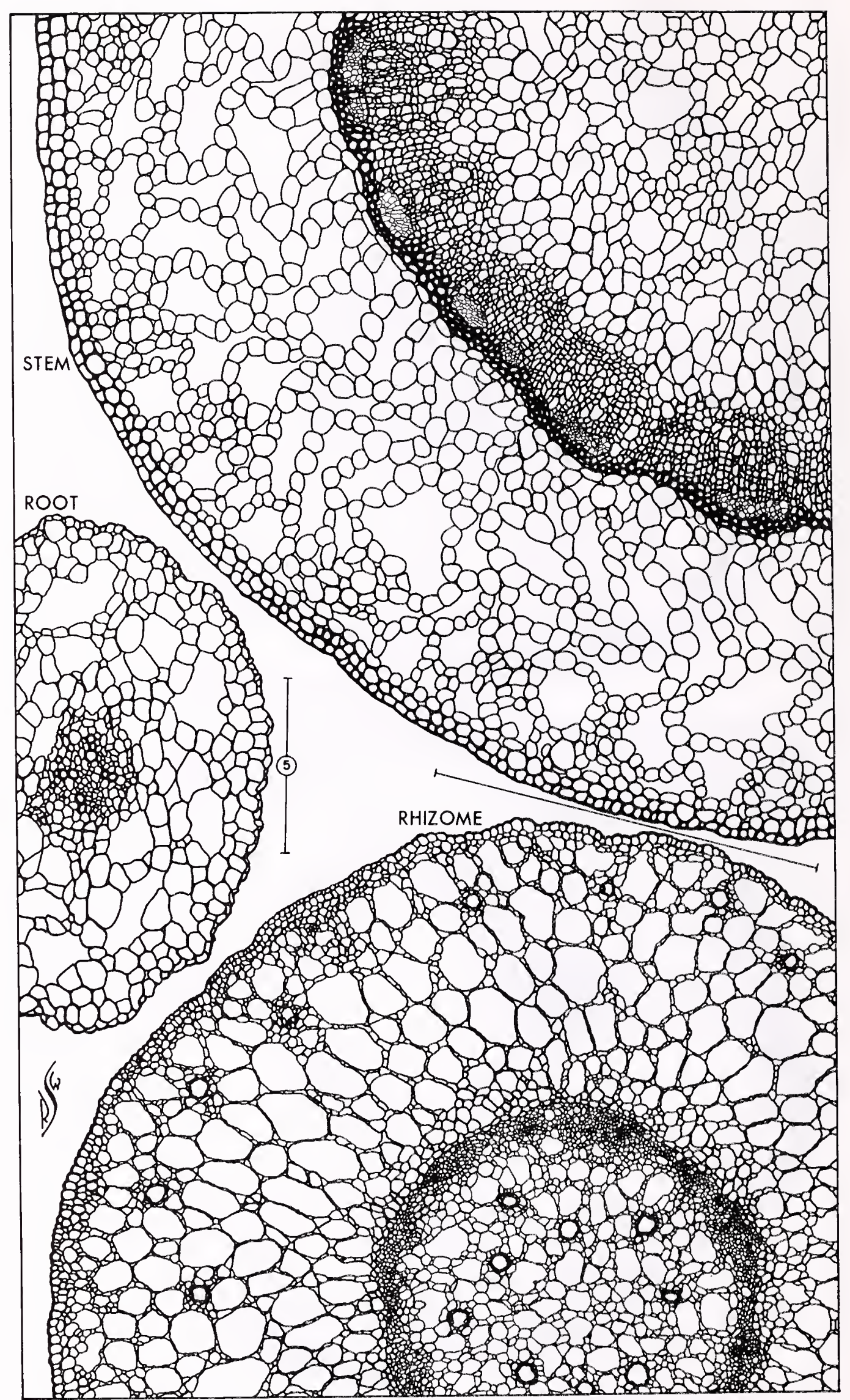




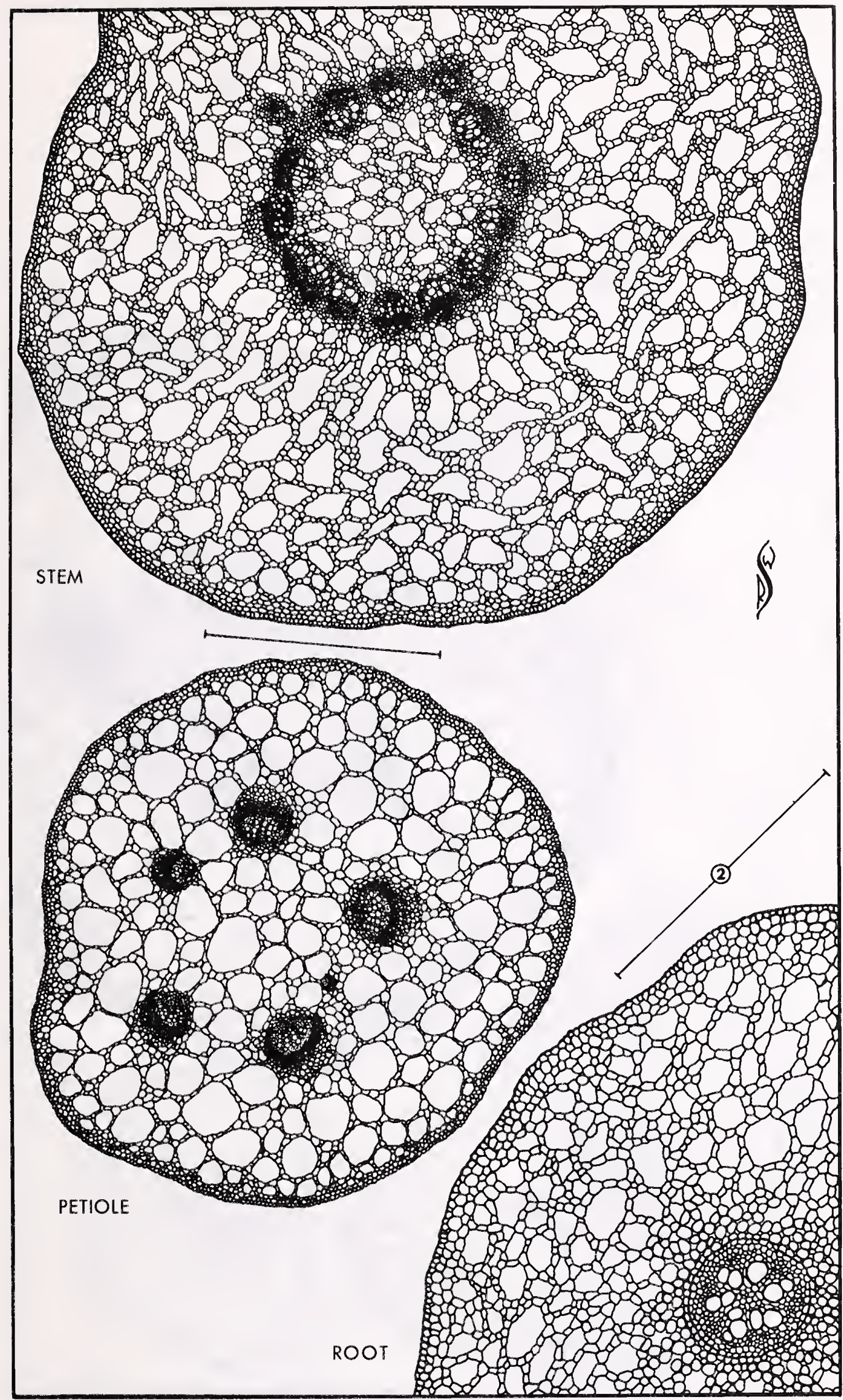

Plate 59

MENYANTHES

M. trifoliała 


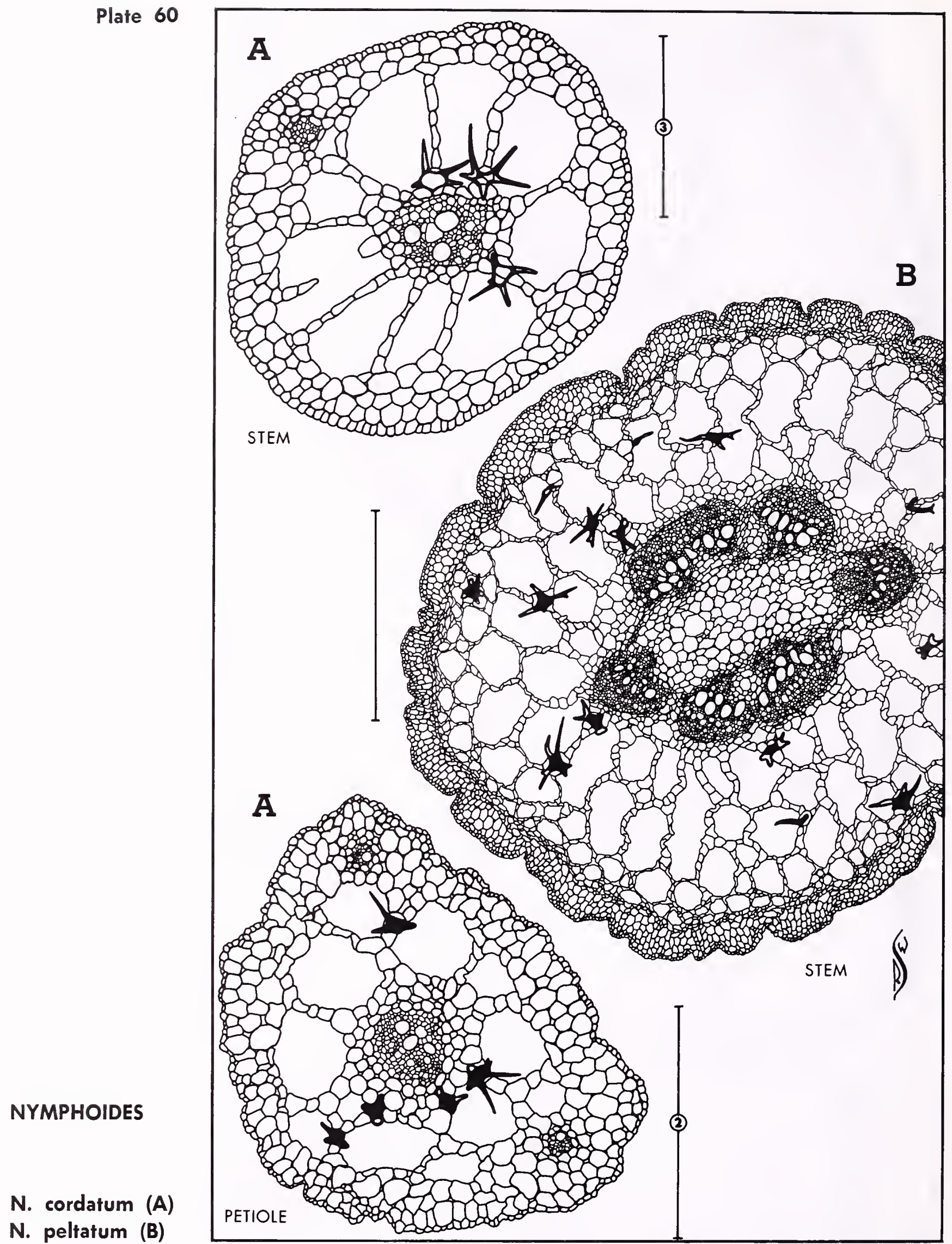




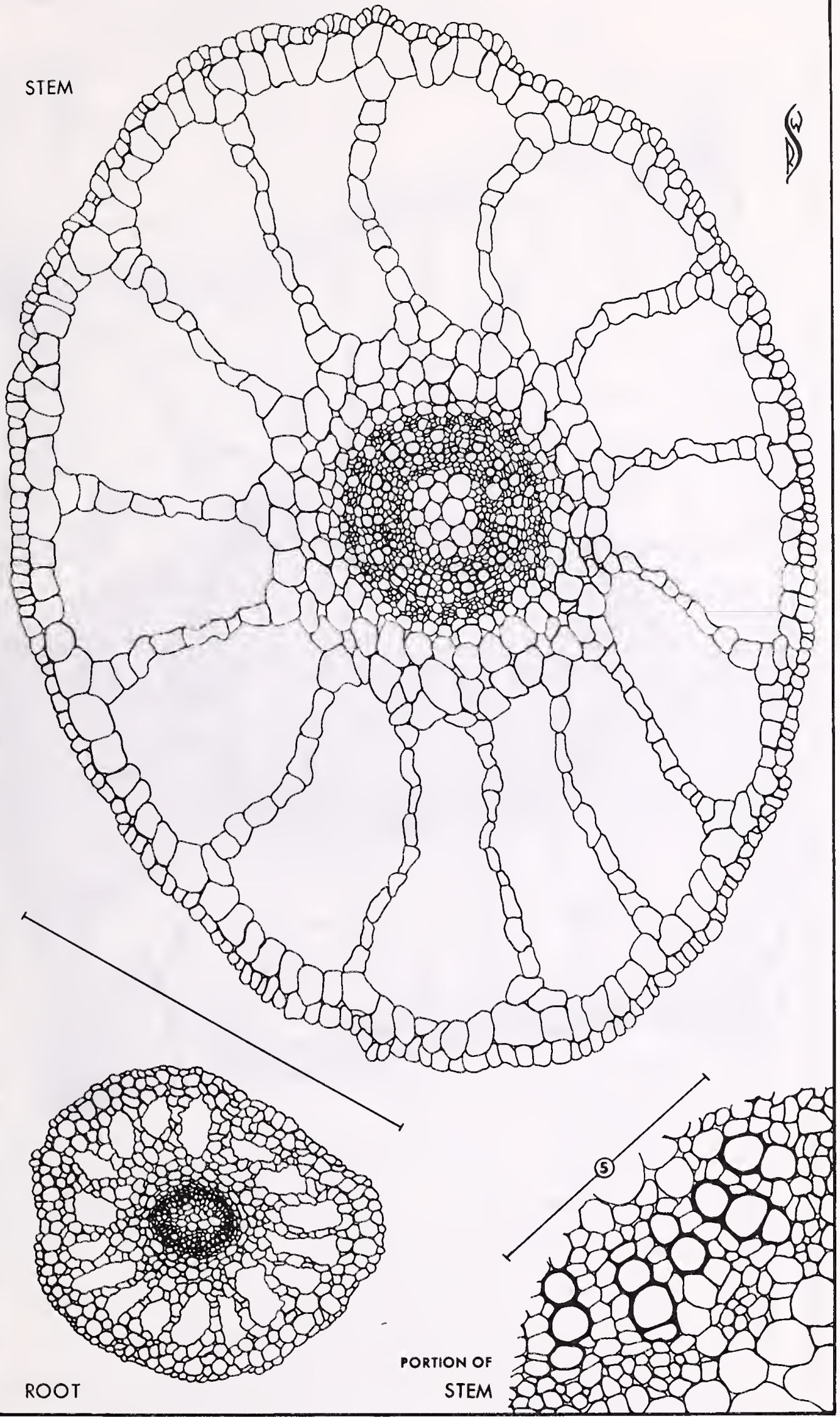

GRATIOLA

G. aurea 


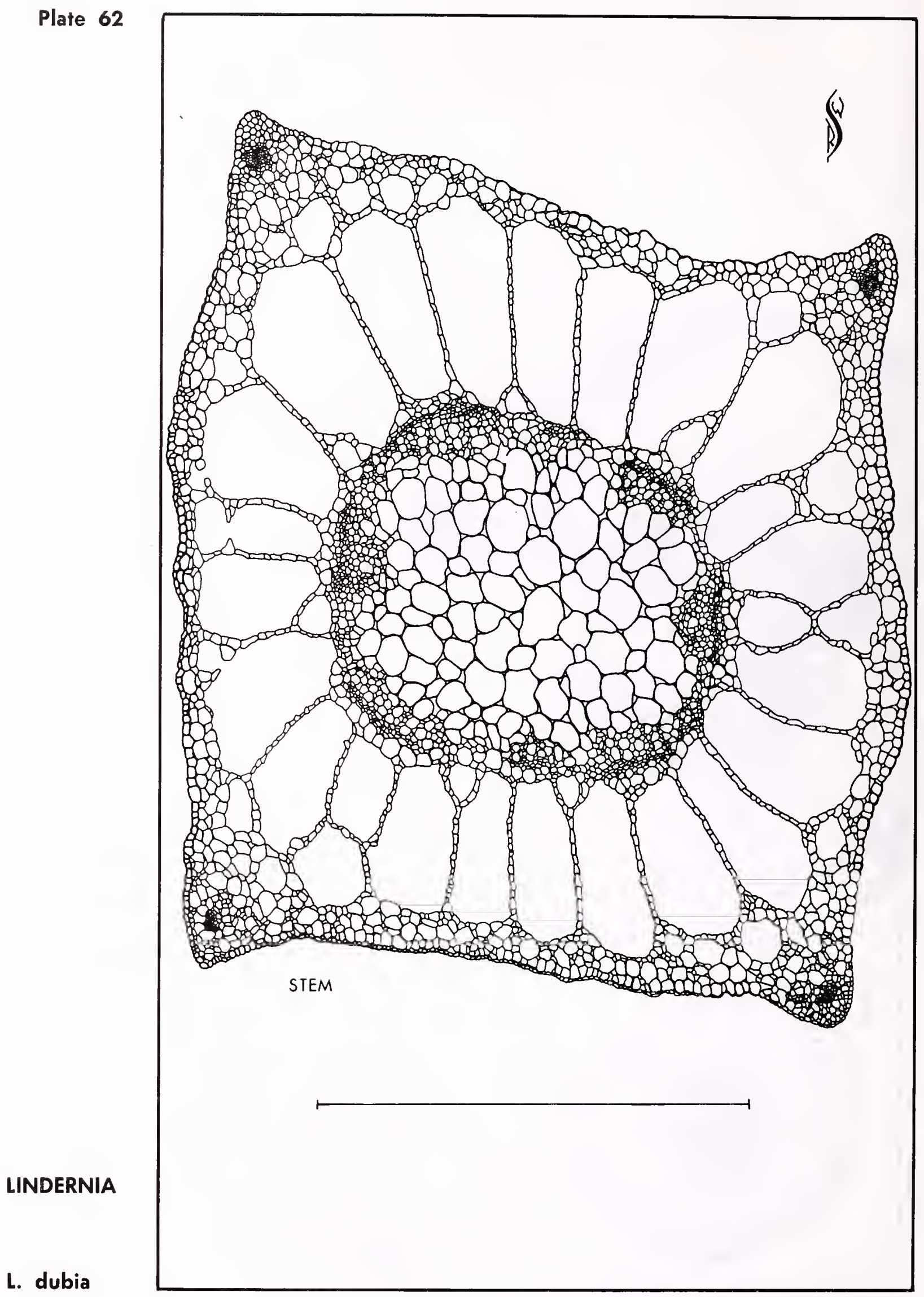




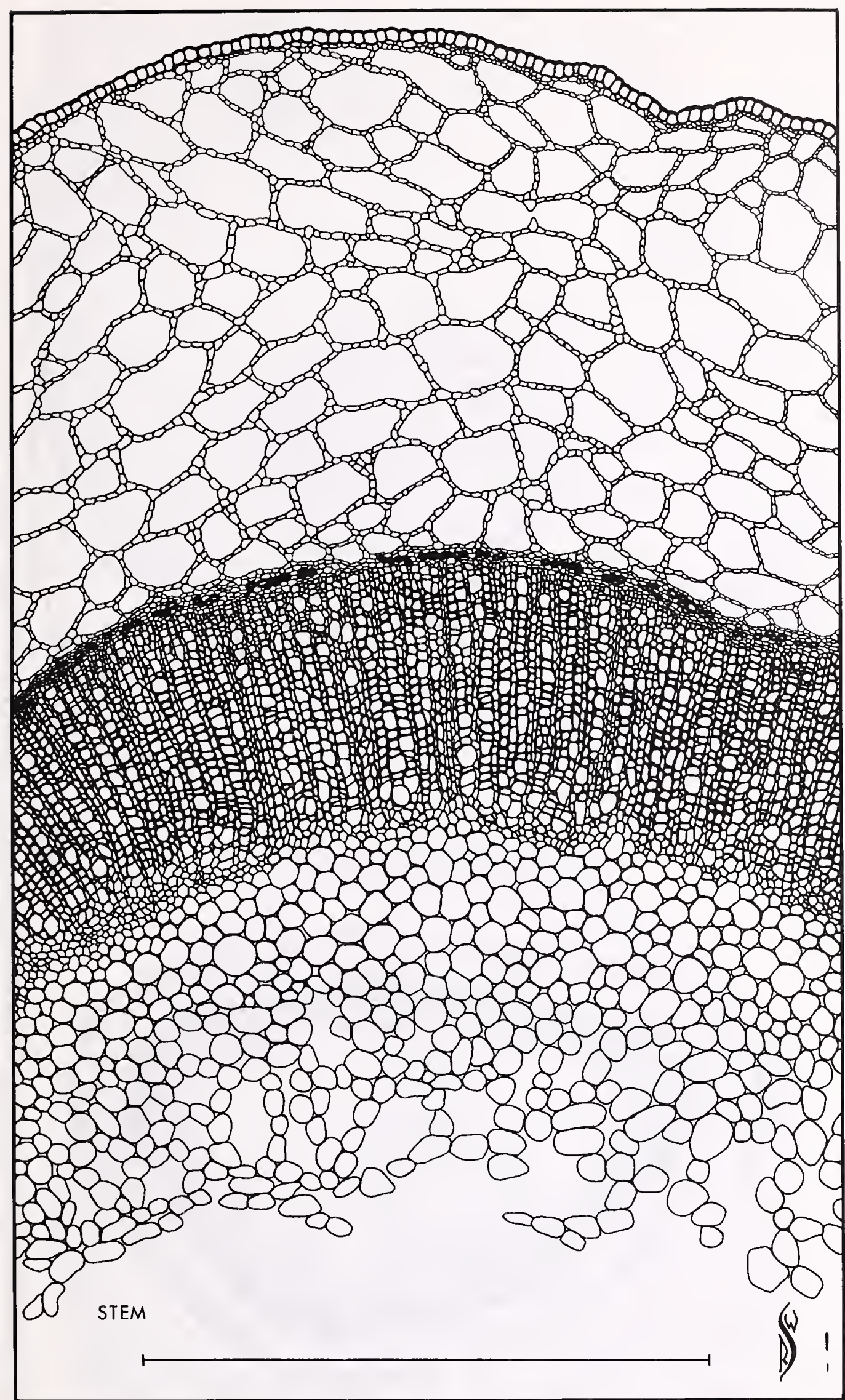

MIMULUS

M. ringens 


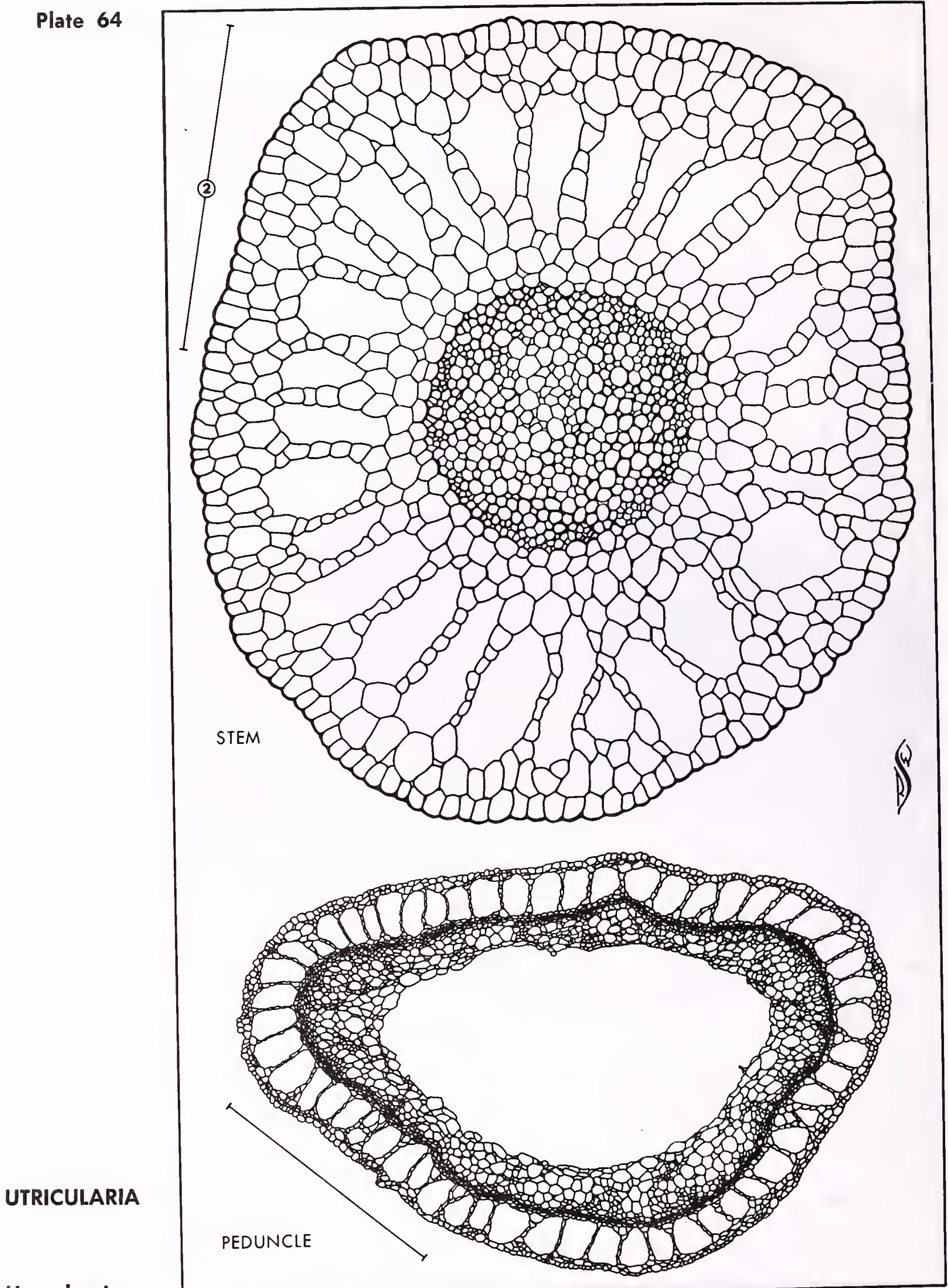

U. vulgaris 


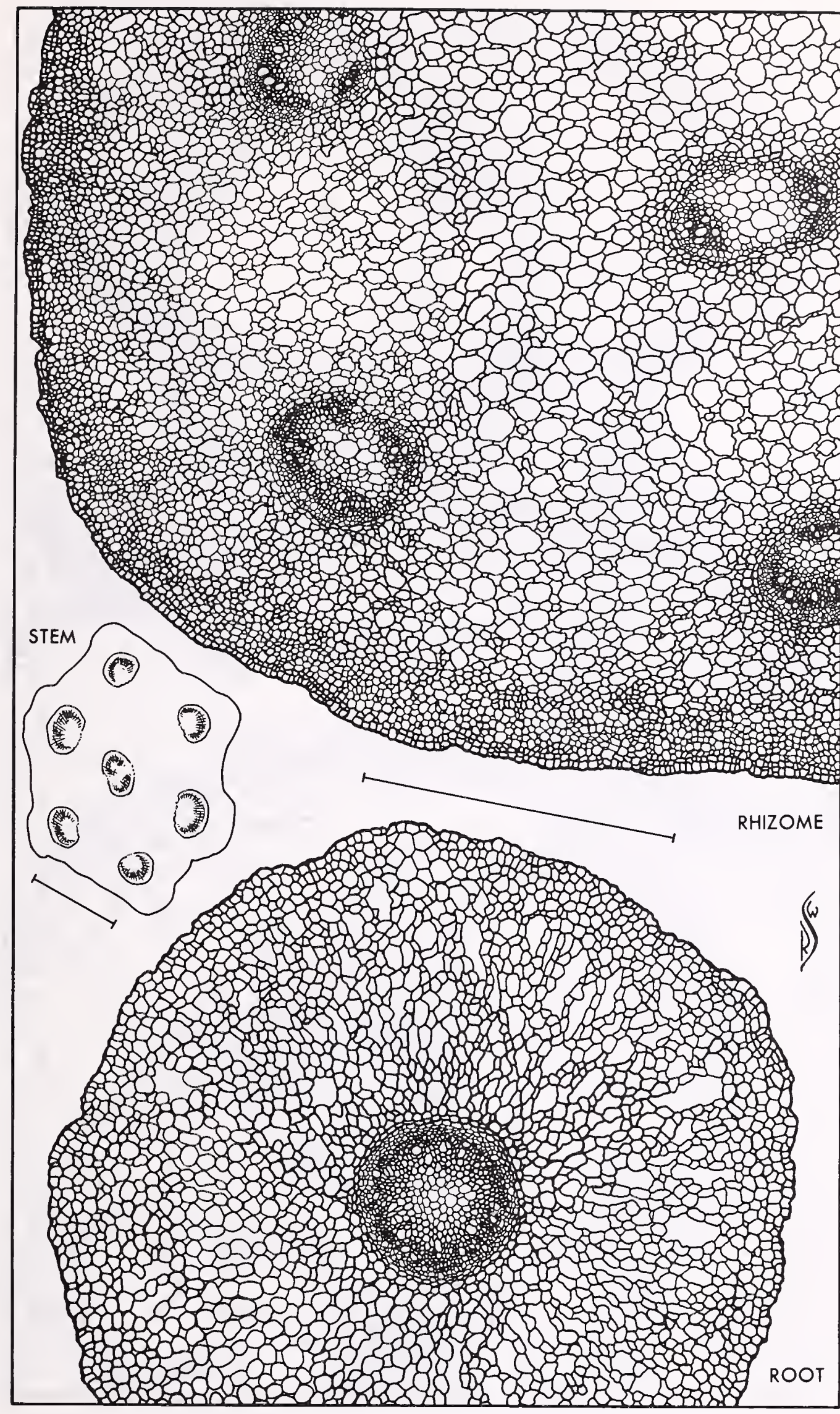

\section{JUSTICIA}




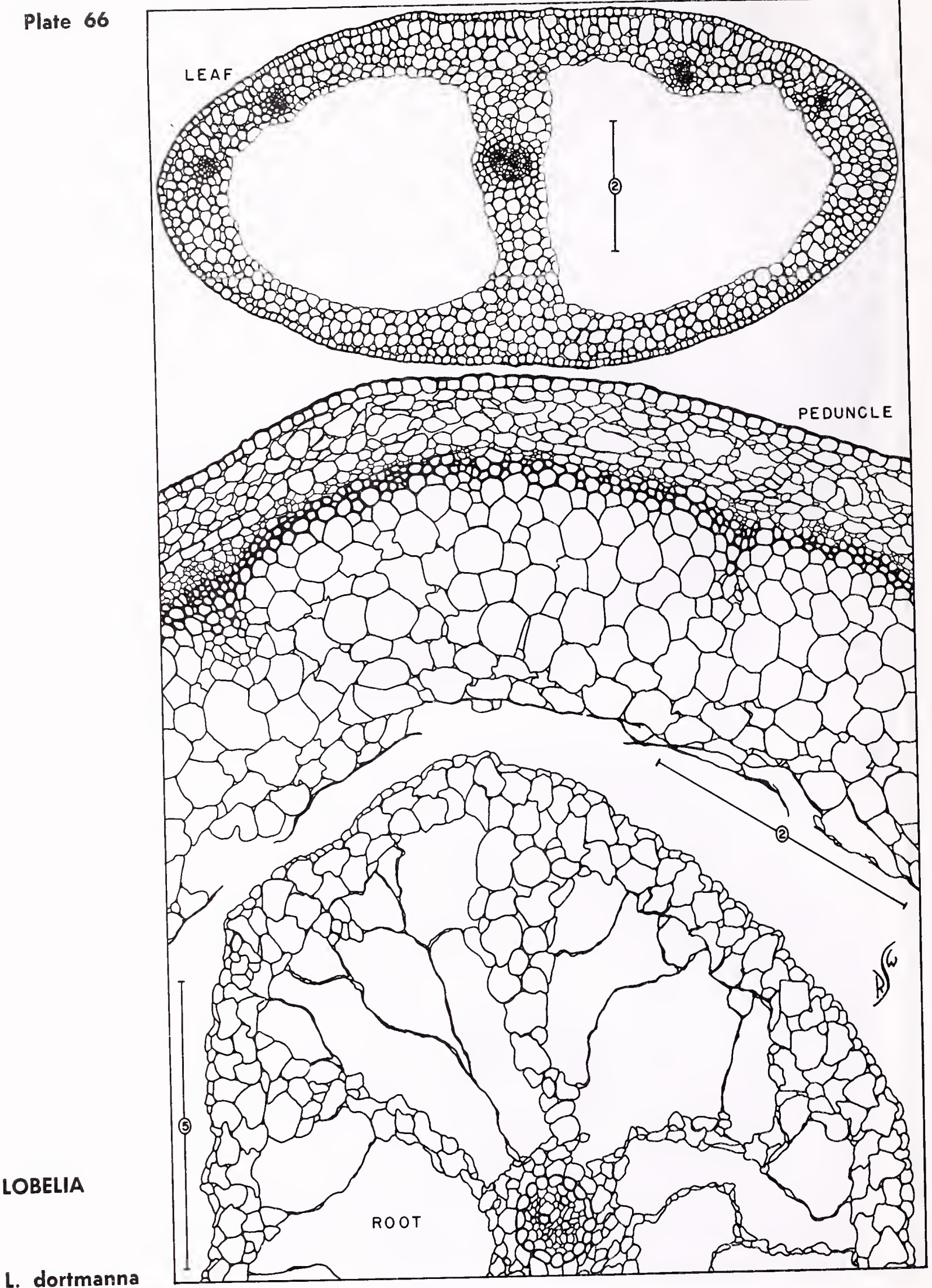




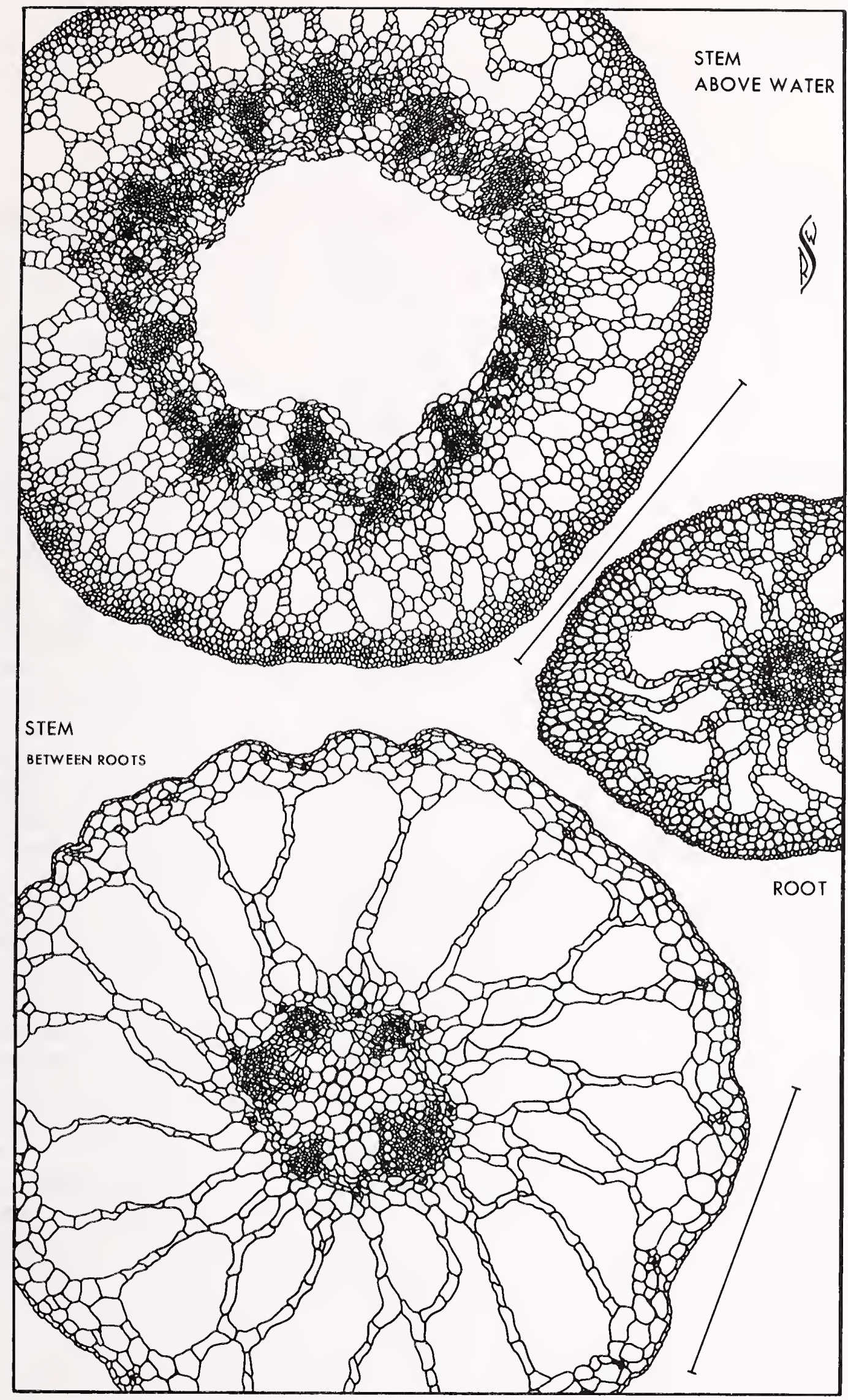

Plate 67

BIDENS

B. beckii 



\section{Index to Genera}

Acorus 17, pl. 34

Alisma 12, pl. 19

Anacharis 13

Armoracia 22, pl. 48

Bidens 27, pl. 67

Brasenia 20, pl. 42

Butomus 13, pl. 22-23

Cabomba 20, pl. 43

Calla 18, pl. 35

Callitriche 22

Caltha 21, pl. 47

Cardamine 3

Carex 13, pk: 26

Castalia 21

Ceratophyllum 21, pl. 46

Cicuta 3

Cladium 14, pl. 27

Cyperus 14

Decodon 3

Dianthera 26

Distichlis 3

Dulichium 14, pl. 28

Echinodorus 3

Elatine 23

Eleocharis 14, pl. 29

Elodea 13, pl. 24

Epilobium 3

Equisetum 5, pl. 1-3

Eriocaulon 18, pl. 37

Eriophorum 16, pl. 30

Fuirena 16, pl. 26

Gratiola 25, pl. 61

Heteranthera 18, pl. 38

Hippuris 24, pl. 56

Hottonia 3

Hydrocotyle 24, pl. 57
Hypericum 22, pl. 50

Hypericum 22

Ilysanthes 25

Impatiens 3

Isoetes $6, \mathrm{pl} .4$

Juncus 19, pl. 40-41

Justicia 26, pl. 65

Limnobium 3

Limosella 3

Lindernia 25, pl. 62

Littorella 3

Lobelia 27, pl. 66

Lophotocarpus 12

Ludwigia 23, pl. 51

Lycopus 3

Lysimachia 24, pl. 58

Lythrum 3

Mariscus 14

Marsilea 6, pl. 5

Megalodonta 27

Mentha 3

Menyanthes 25, pl. 59

Mimulus 25, pl. 63

Myriophyllum 23, pl. 54-55

Najas 11, pl. 17

Nasturtium 22, pl. 49

Nelumbo 20

Neobeckia 22

Nuphar 20, pl. 44

Nymphaea 21, pl. 45

Nymphaea 21

Nymphoides 25, pl. 60

Orontium 18

Peltandra 18, pl. 36

Peplis 3

Philotria 13
Phragmites 3

Podostemum 3

Polygonum 3

Pontederia 19, pl. 39

Potamogeton 7, pl. 8-14

Proserpinaca 24, pl. 56

Radicula 22

Ranunculus 21

Rhynchospora 16, pl. 31

Rorippa 22

Rorippa 22

Rumex 20

Ruppia 11, pl. 15

Sagittaria 12, pl. 20-21

Salicornia 20

Samolus 3

Scheuchzeria 12, pl. 18

Scirpus 16, pl. 32-33

Scirpus 14

Scutellaria 3

Sisymbrium 22

Sium 3

Sparganium 7, pl. 6-7

Subularia 22

Trachysperma 25

Trapa 23, pl. 52-53

Triadenum 23, pl. 50

Typha 3

Utricularia 26, pl. 64

Vallisneria 13, pl. 25

Veronica 3

Zannichellia 11, pl. 16

Zostera 11

Zosterella 18 


